\title{
Psiholingvistički pristup strukturno-značenjskim čimbenicima u obradi odnosnih rečenica
}

Matić, Ana

Doctoral thesis / Disertacija

2020

Degree Grantor / Ustanova koja je dodijelila akademski / stručni stupanj: University of Zagreb, University of Zagreb, Faculty of Humanities and Social Sciences / Sveučilište u Zagrebu, Filozofski fakultet

https://doi.org/10.17234/diss.2020.8937

Permanent link / Trajna poveznica: https://urn.nsk.hr/urn:nbn:hr:131:711004

Rights / Prava: In copyright/Zaštićeno autorskim pravom.

Download date / Datum preuzimanja: 2023-04-26

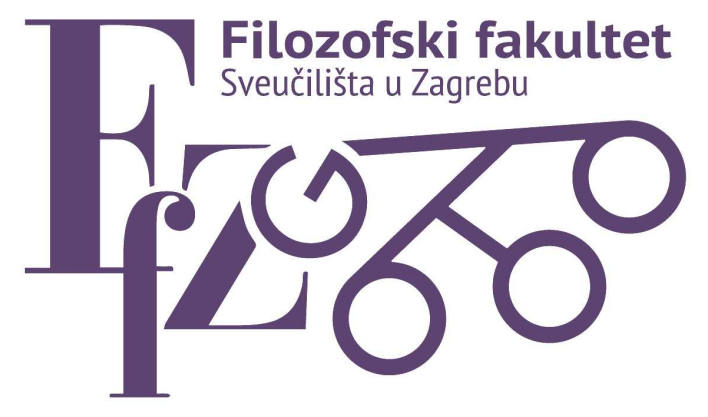

Repository / Repozitorij:

ODRAZ - open repository of the University of Zagreb

Faculty of Humanities and Social Sciences
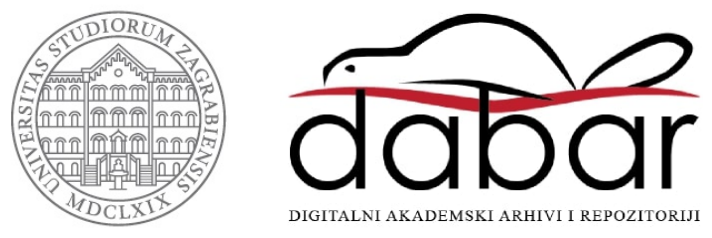


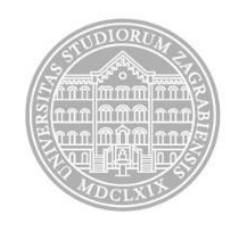

Filozofski fakultet

Poslijediplomski doktorski studij lingvistike

Ana Matić

\section{PSIHOLINGVISTIČKI PRISTUP STRUKTURNO-ZNAČENJSKIM ČIMBENICIMA U OBRADI ODNOSNIH REČENICA}

DOKTORSKI RAD

Zagreb, 2020. 


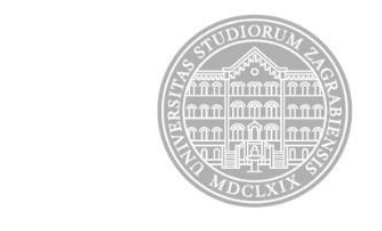

Filozofski fakultet

Poslijediplomski doktorski studij lingvistike

\author{
Ana Matić
}

\title{
PSIHOLINGVISTIČKI PRISTUP STRUKTURNO-ZNAČENJSKIM ČIMBENICIMA U OBRADI ODNOSNIH REČENICA
}

\author{
DOKTORSKI RAD
}

\author{
Mentori: \\ Prof.dr.sc. Melita Kovačević \\ Prof.dr.sc. Ida Raffaelli
}

Zagreb, 2020. 


\section{잉 \\ University of Zagreb}

Faculty of Humanities and Social Sciences Postgraduate study programme in Linguistics

Ana Matić

\section{PSYCHOLINGUISTIC APPROACH TO STRUCTURAL-SEMANTIC FACTORS IN PROCESSING RELATIVE CLAUSES}

DOCTORAL THESIS

Supervisors:

Prof Melita Kovačević, PhD

Prof Ida Raffaelli, PhD

Zagreb, 2020 


\section{Sadržaj}

SAŽETAK

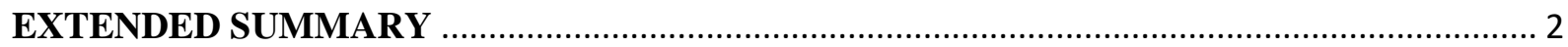

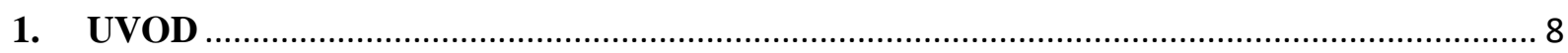

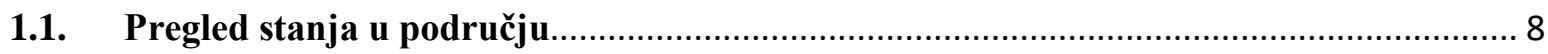

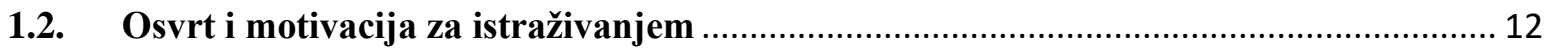

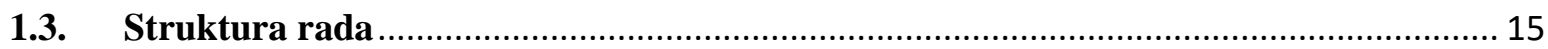

2. SINTAKTIČKA OBRADA I MODELI SINTAKTIČKE OBRADE .................................. 17

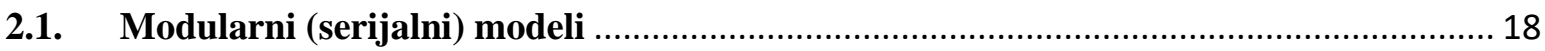

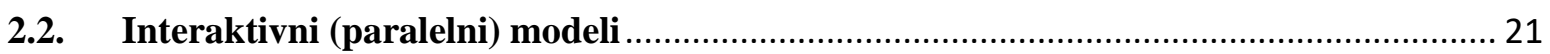

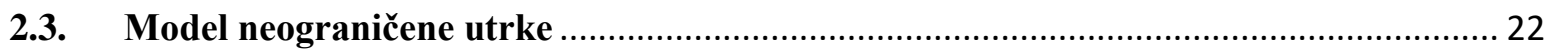

2.4. Dosezi i ograničenja tradicionalnih modela .............................................................. 24

3. PREFERENCIJE VEZIVANJA U ODNOSNIM REČENICAMA ..................................... 25

3.1. Načelo kasnoga zatvaranja u okviru modela vijugavoga puta ....................................... 26

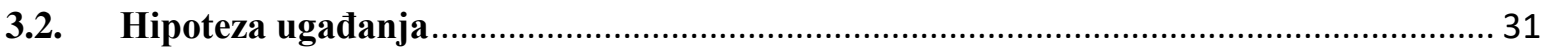

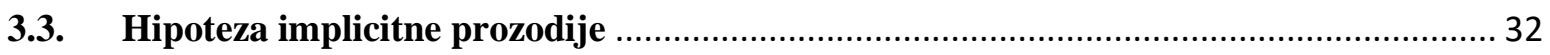

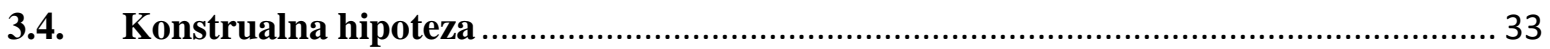

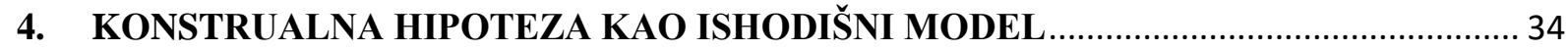

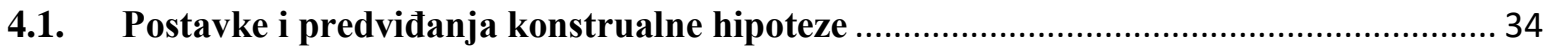

4.2. Istraživanja u okviru konstrualne hipoteze …........................................................ 38

4.3. Kritički osvrt i nedostatci konstrualne hipoteze .................................................. 42

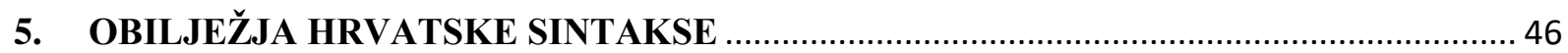

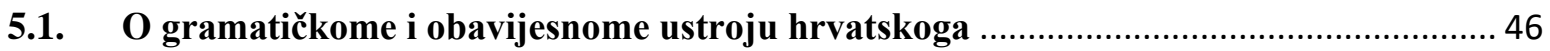

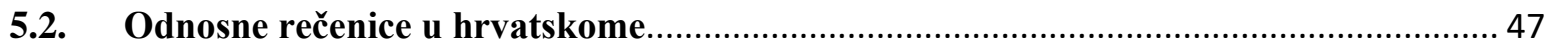

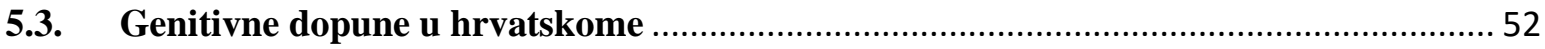

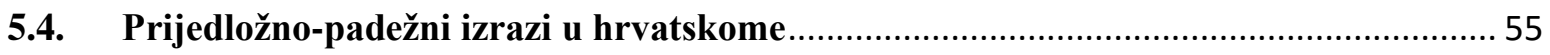

6. OSTALI ČIMBENICI KOJI UTJEČU NA SINTAKTIČKU OBRADU .............................. 57 


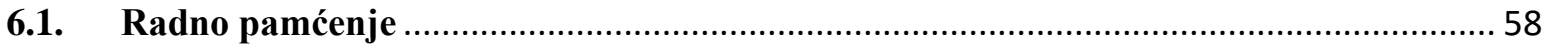

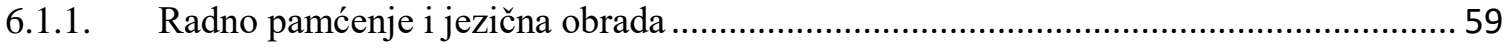

6.1.2. Utjecaj raspona radnoga pamćenja na sintaktičku obradu i preferencije vezivanja ...... 62

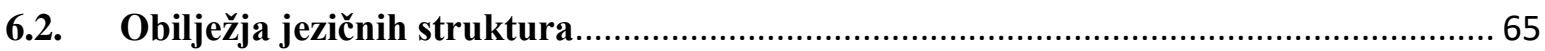

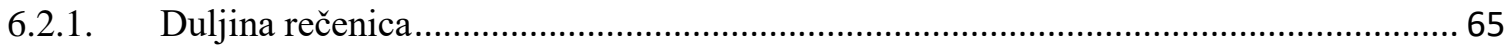

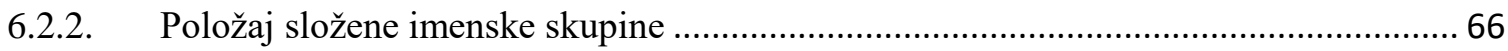

6.2.3. Obilježja imenica unutar imenske skupine (konkretnost i živost)................................67 67

6.2.4. Vrsta i obilježja relativizatora ....................................................................... 70

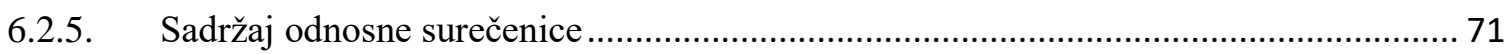

7. NAČINI ISPITIVANJA PREFERENCIJA VEZIVANJA …................................................. 75

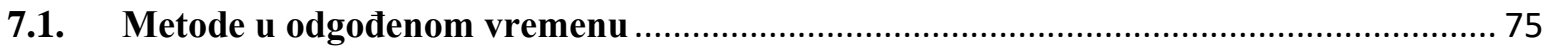

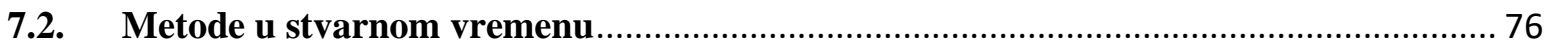

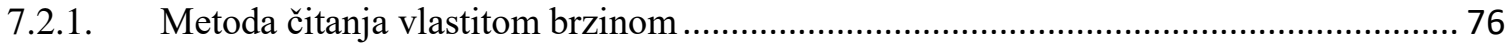

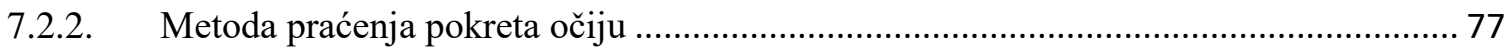

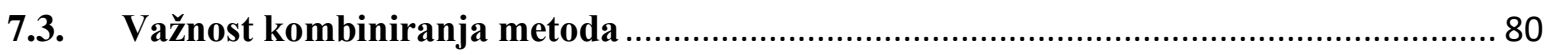

8. ISTRAŽIVANJA PREFERENCIJA VEZIVANJA U HRVATSKOME ............................. 81

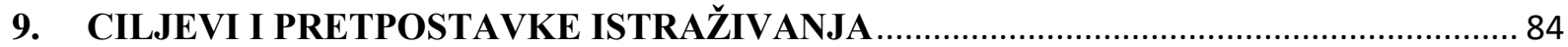

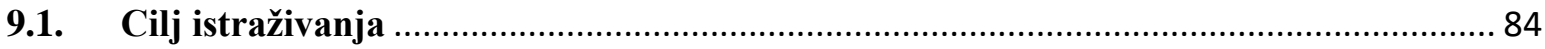

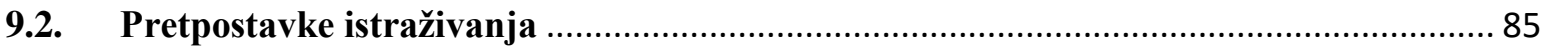

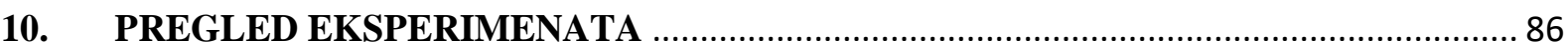

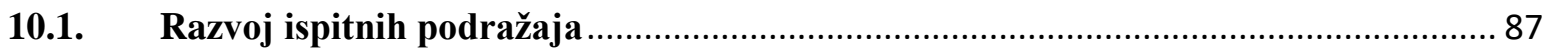

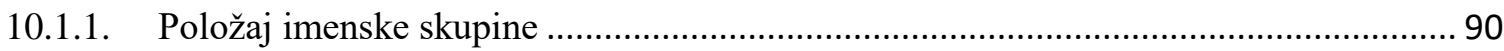

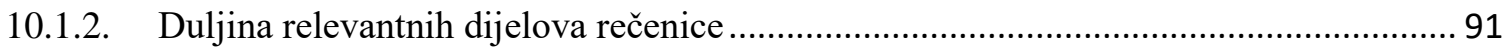

10.1.3. Čestotnost imenica unutar imenske skupine........................................................... 93

10.1.4. Predispitivanja: utvrđivanje valjanosti podražaja ....................................................... 95

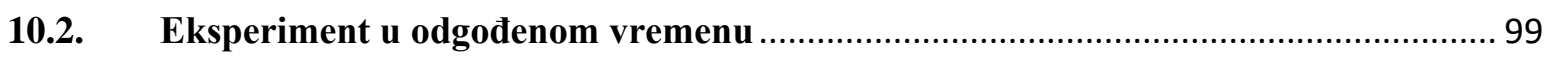

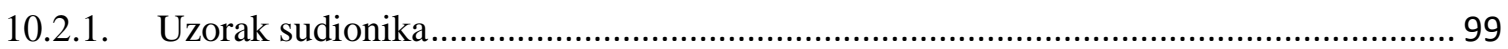

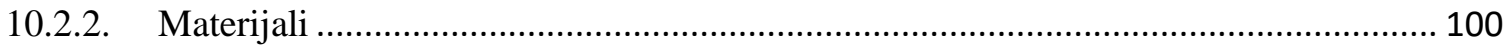




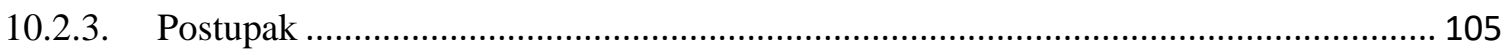

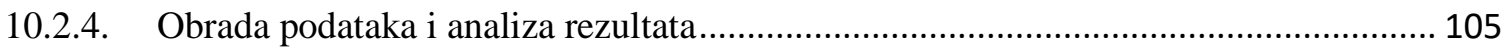

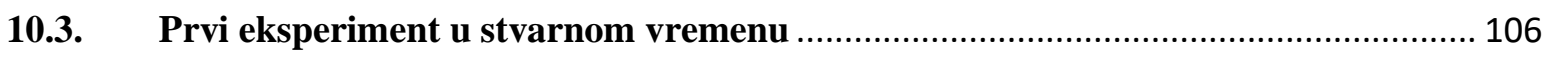

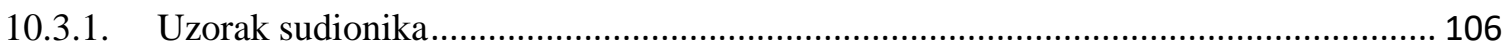

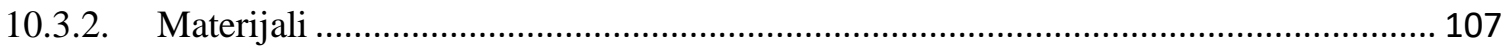

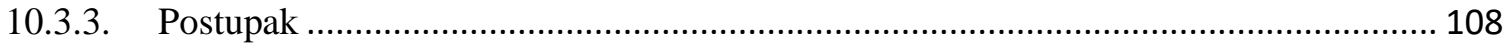

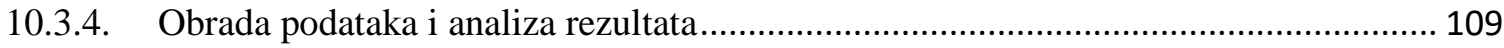

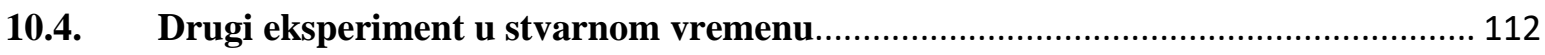

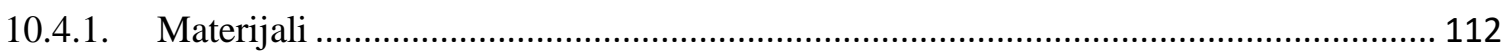

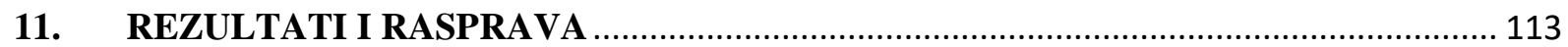

11.1. Rezultati ispitivanja preferencija u odgođenom vremenu ................................... 113

11.2. Rezultati ispitivanja preferencija u stvarnom vremenu ....................................... 120

11.2.1. Utjecaj vrste imenske skupine na preferencije vezivanja (prvi eksperiment) ............. 120

11.2.2. Utjecaj obilježja živosti na preferencije vezivanja (drugi eksperiment)..................... 129

11.3. Kvalitativni podatci: osjećaj izvornoga govornika ............................................ 140

11.4. Usporedba obrade dvosmislenih i nedvosmislenih rečenica .................................... 142

11.5. Spoznaje u općem psiholingvističkom i jezično-specifičnom kontekstu ................... 146

11.5.1. Međuovisnost razina sintaktičke obrade................................................................ 146

11.5.2. Preferencije vezivanja u hrvatskome: osvrt na konstrualnu hipotezu i osobitosti

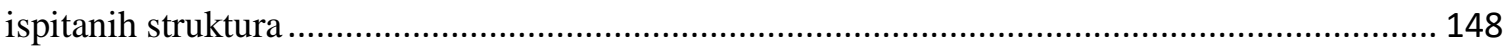

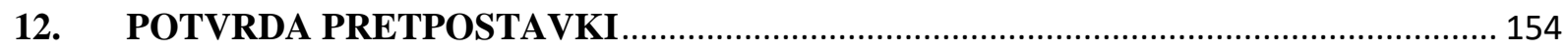

13. ZNANSTVENI DOPRINOS I OGRANIČENJA ISTRAŽIVANJA .............................. 155

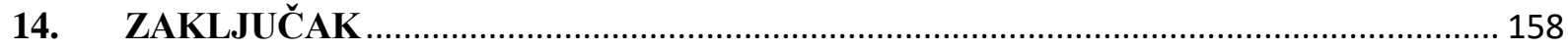

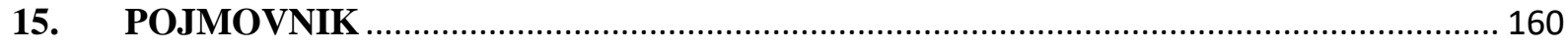

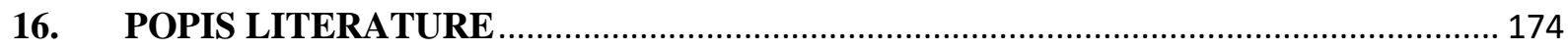

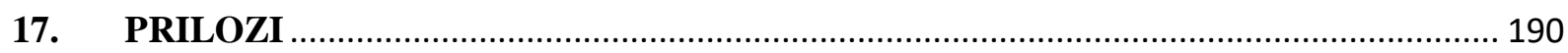

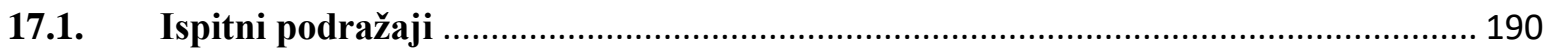

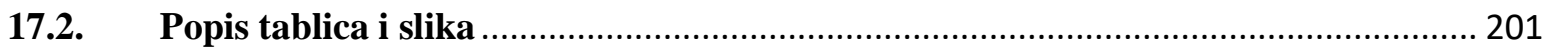




\section{O MENTORICAMA}

Melita Kovačević redovita je profesorica u trajnom zvanju na Odsjeku za logopediju Edukacijsko-rehabilitacijskog fakulteta Sveučilišta u Zagrebu. Nositeljicom je predmeta na preddiplomskoj, diplomskoj i doktorskoj razini na matičnome Fakultetu te na Arhitektonskome fakultetu i Filozofskome fakultetu Sveučilišta u Zagrebu. Predmeti na kojima izvodi nastavu pokrivaju široki spektar psiholingvistike, kognitivne psihologije i jezičnoga razvoja. Njezini primarni istraživački interesi su u području psiholingvistike i jezičnoga razvoja, bilo urednog ili narušenog, što se odražavalo i u temama domaćih i međunarodnih istraživačkih projekata kojima je bila voditeljicom ili suradnicom. Objavila je preko 50 znanstvenih radova, od kojih veći broj u međunarodnim publikacijama, časopisima ili knjigama etabliranih izdavača, poput de Gryter Mouton. Urednicom je ili suurednicom većega broja znanstvenih publikacija, tematskih brojeva časopisa te je pokrenula prilagodbu i standardizaciju većega broja mjernih instrumenta, testova i ljestvica u području jezičnoga razvoja.

Pokrenula je Laboratorij za psiholingvistička istraživanja, kao i sveučilišni doktorski studij Jezik i kognitivna neuroznanost, koji vodi od 2003. godine. Pod njezinim je mentorstvom dosad doktoriralo sedam doktoranada, od kojih većina razvija uspješnu akademsku karijeru, a četiri doktoranda su u procesu stjecanja doktorata. Od 2006. do 2014. godine obnašala je funkciju Prorektorice za istraživanje i tehnologiju Sveučilišta u Zagrebu. 
Ida Raffaelli redovita je profesorica na Odsjeku za lingvistiku Filozofskoga fakulteta Sveučilišta u Zagrebu. Predaje Sintaksu, Semantiku te predmete vezane uz područje kognitivne lingvistike što su uz dijakronijsku semantiku njezina temeljna područja znanstvenoga interesa. Objavila je veći broj znanstvenih, preglednih i stručnih radova u međunarodnim časopisima i knjigama te domaćim jezikoslovnim časopisima koji su po vrsnoći izjednačeni s časopisima s međunarodnom recenzijom. Autoricom je dviju monografskih znanstvenih knjiga: Značenje kroz vrijeme - poglavlja iz dijakronijske semantike (2009) i O značenju - uvod u semantiku (2015) te triju uredničkih knjiga od kojih je Lexicalization patterns in color naming: a crosslinguistic perspective (zajedno s Danielom Katunar i Barbarom Kerovec) objavljena 2019. kod Johna Benjaminsa. Sudjelovala je ili bila voditeljicom niza domaćih i međunarodnih znanstvenih projekata od kojih se ističu projekti Leksička semantika u izradi hrvatskoga WordNeta (voditeljica), EOSS (Evolution of Semantic Systems) na Max Planck institutu za psiholingvistiku, Nijmegen na kojemu je bila voditeljicom hrvatskoga tima, te ACCOMPLISSH: Accelerate Co-creation by Setting a Multi-actor Platform for Impact from Social Sciences and Humanities (Obzor 2020) na kojemu je bila članicom savjetodavnoga odbora. Bila je glavnom urednicom jednog od najuglednijih hrvatskih jezikoslovnih časopisa Suvremena lingvistika (2005-2015). Od akademske godine 2018./2019. voditeljicom je Poslijediplomskoga doktorskoga studija lingvistike na Filozofskome Fakultetu Sveučilišta u Zagrebu. Od 2017. članicom je Matičnoga odbora za filologiju i Područnoga vijeća za humanističke znanosti u kojima je potpredsjednicom za visoko obrazovanje. 
Ova je disertacija izrađena u sklopu projekta Jezična obrada u odraslih govornika (HRZZUIP-11-2013-2421) koji je financijski podržala Hrvatska zaklada za znanost (voditeljica: izv. prof. dr. sc. Jelena Kuvač Kraljević, Sveučilište u Zagrebu, Edukacijsko-rehabilitacijski fakultet, Odsjek za logopediju) 
Tijekom nastajanja ovoga rada imala sam svesrdnu podršku velikoga broja ljudi. Hvala mojim mentoricama na uloženome trudu i udijeljenim savjetima.

Hvala svim sudionicima istraživanja na izdvojenome vremenu i pruženome povjerenju. Hvala mojim najmilijima što su me gurali dalje i vjerovali u mene kada ni sama nisam. 


\section{SAŽETAK}

Sintaktička obrada podrazumijeva procese uključene u izgradnju sintaktičkih struktura tijekom jezičnoga razumijevanja i proizvodnje. Postoje mnogi modeli sintaktičke obrade, mahom u području razumijevanja. Prijašnja istraživanja obrade odnosnih rečenica u kojima zamjenici prethode složene imenske skupine potvrdila su međujezične, unutarjezične i individualne razlike, ali je nesustavnost u istraživačkoj metodologiji otežala donošenje zaključaka o čimbenicima koji su odlučujući u pojedinome jeziku.

Provedeno istraživanje pripada psiholingvističkom ispitivanju preferencija koje govornici imaju prilikom tumačenja odnosnih rečenica i provedeno je u okviru konstrualne hipoteze koja predviđa razlike u preferencijama ovisno o vrsti imenske skupine (NP) koja prethodi odnosnoj surečenici (genitivna dopuna; GD i prijedložno-padežni izraz; PPI).

Glavni je cilj bio utvrditi o kojim strukturno-značenjskim osobitostima NP ovise obrada i način na koji govornici tumače odnosne rečenice te se pretpostavilo: 1) da će postojati preferencija vezivanja na prvu imenicu u NP u genitivnoj dopuni; 2) da će postojati preferencija vezivanja na drugu imenicu u NP koju čini prijedložno-padežni izraz; 3) da će obilježje živosti olakšati sintaktičku obradu i utjecati na promjene preferencija. Istraživanje je provedeno u odgođenom (upitnik) i stvarnom (praćenje pokreta očiju) vremenu, a sudionici su bili govornici hrvatskoga jezika. U prvome je dijelu sudjelovalo njih 97 , a u drugome 48, ovisno o rezultatima na testu raspona radnoga pamćenja.

Rezultati dobiveni kombinacijom metoda obrađeni su kvantitativno i kvalitativno i pokazali su preferencije prema prvoj imenici u obje vrste NP. Prva je pretpostavka stoga prihvaćena, a druga odbačena. Utvrđeno je i da obilježje živosti olakšava obradu, iako ne utječe na promjene preferencija, čime je treća pretpostavka djelomično prihvaćena. Dodatna je vrijednost što su se efekti dobili na ranim mjerama, a kvalitativni rezultati potkrijepili su spoznaje da se govornici tijekom tumačenja iskaza oslanjaju na višestruke razine obavijesti.

Ključne riječi: psiholingvistički pristup, sintaktička obrada, preferencije vezivanja, odnosne rečenice, konstrualna hipoteza, strukturno-značenjski čimbenici. 


\section{EXTENDED SUMMARY}

Syntactic processing is a rapid and highly automatized process involved in the integration of new information during language comprehension and production (Van Gompel \& Pickering, 2007). These processes proceed in an incremental fashion, i.e. once each word is encountered, it is integrated into the sentence analysis. Despite numerous research, there are still many remaining questions about the exact underlying mechanisms of syntactic processing, such as what drives the processor; which information a speaker of a language predominately relies on during processing and when; which linguistic and nonlinguistic factors are involved and whether there are crosslinguistic, intralinguistic and individual differences in the process (Papadopoulou, 2006).

Inconsistencies in research methodology pose additional challenges in making firm conclusions, especially within a particular language. Therefore, there remains a need for conducting new experiments with more rigorous control of nonlinguistic (i.e., working memory capacity) and linguistic (i.e., structural-semantic) factors that would bring about novel findings based on the data in a range of languages, respecting their structural and other features. In search of the structures that could be systematically used in crosslinguistic studies of syntactic processing, ambiguous clauses started to stand out. Even though ambiguity can occur in all utterances that allow for multiple interpretations considering the linguistic and situational context (Van Gompel \& Pickering, 2007: 290; Raffaelli, 2015: 267), ambiguous relative clauses (RC) are considered a standard as " $\mathrm{RC}$ attachment ambiguity occurs in a variety of languages and thus constitutes an ideal test case for investigating whether the human sentence processor varies from language to language" (Cuetos, Mitchell \& Corley, 1996: 148). By analysing these sentences one can get the notion of linguistic factors that drive syntactic processing in the absence of a broader context (see also Raffaelli, 2015: 266-267). These are firm justifications for analysing the ways speakers of different languages interpret ambiguous RCs and whether they prefer attaching the clause to the first $(\mathrm{N} 1)$ or to the second $(\mathrm{N} 2)$ noun within the noun phrase (NP) when both are possible (Hemforth, Konieczny \& Scheepers, 2000a). Attachment preference studies are mostly performed using offline and online methods, for example forcedchoice questionnaires and eye-tracking.

This doctoral thesis is a psycholinguistic sentence processing study that investigates attachment preferences in Croatian, and is conducted within one of many sentence processing models, the construal (Frazier \& Clifton, 1996). 
Construal hypothesis highlights the importance of structural-semantic relations of the two nouns within the NP preceding a subsequent relative clause. If the two nouns are in nonprepositional genitive forms, then none of them is thematically licensed and attachment can be influenced by other factors. Nevertheless, N1 attachment (or high attachment) is somewhat preferred as these two nouns belong to the same processing domain. On the other hand, if an NP preceding the relative clause constitutes a prepositional phrase, then the preposition is considered thematically-licensing, i.e. it can cause a focus shift and change of preference. Therefore, this model predicts N2 or low attachment across languages (Frazier \& Clifton, 1996: 73).

Since according to construal differences in syntactic processing and attachment preferences are explained by these types of structures (RCs with NP in non-prepositional genitive forms and thematically-licensing prepositional phrases) these are the structures finally involved in the current attachment preference doctoral research. Prior to the experimental part of the thesis, a critical overview of the syntactic processing models is provided, as well as the review of findings of similar experiments. After the results section, general discussion is given in a broader psycholinguistic context and in a language-specific one, with reference to the Croatian language and its structures.

The main aim of the study was to investigate which structural-semantic factors of NP preceding RCs explain syntactic processing and speakers' attachment preferences in the Croatian language. Additional aim was to deliver relevant findings for Croatian, and thus to contribute both to the general psycholinguistic perspective of the studied behaviours, and to the language-specific one.

Within the construal model, three hypotheses were formed:

H.1. Considering the first postulate of the construal and recent findings of relative clauses in Croatian, if the NP is in non-prepositional genitive form, N1 attachment preference is expected.

H.2. Considering the second postulate of the construal, if the NP is a prepositional phrase in which the preposition is potentially thematically licensing and causes the focus shift, N2 attachment preference is expected.

H.3. Considering the features of the Croatian syntax and former studies in Croatian, it is expected that, in the absence of morphological cues, animacy will facilitate processing and influence the change in attachment preference. 
The study has been conducted using both offline (a judgment task in the form of a forced-choice questionnaire) and online (eye-tracking) methods. Qualitative data have also been gathered and analysed based on some of the participants' comments and answers.

The questionnaire stimuli consisted of ambiguous relative clauses with both attachment sites equally plausible, and the eye-tracking stimuli consisted of both ambiguous and unambiguous sentences, i.e., those with experimental control of the attachment. The N1 and N2 attachment in those stimuli were forced by either grammatical, i.e. morphological means (gender agreement) or semantic means (semantic plausibility). There were also filler sentences which were completely unambiguous and randomly displayed to participants.

Since several other factors can influence preferences besides the type of the NP, those have also been carefully controlled for. Stimuli were therefore constructed for the purpose of this doctoral study, and were not mere translations of stimuli used in other languages and studies. These additional control factors were as follows: 1) subject position of the NP; 2) length of the NP and RC; 3) frequency of the nouns within the NP; 4) number (singular) of the nouns within the $\mathrm{NP}$; and 5) either the control or the manipulation with gender agreement and semantic plausibility of the structure. The validity of the stimuli has been examined and confirmed by independent participants who were not involved in the main study.

Participants were monolingual speakers of the Croatian language, without the history of neurological or language deficits. Ninety-seven (97) were included in the first offline experiment, and forty-eight (48) of them were selected to participate in two subsequent online experiments. The selection was based on their working memory capacity (WMC), i.e. speakers with extremely low or extremely high WMC in relation to the rest of the group were excluded from the study. This was decided since some research point to the correlation of WMC and attachment preferences, but the exact nature of this correlation remains unresolved, and should therefore at least be controlled (Swets et al., 2007; Traxler, 2007; Payne et al., 2014, ...).

The results were analysed quantitatively applying parametric statistics methods, and some of the participants' comments have been analysed qualitatively. Questionnaire data consisted of coded answers ( 1 for N1 response and 0 for N2) and afterwards the percentages of N1 and N2 attachment preferences across participants have been calculated, for both type of NPs separately (genitive forms and prepositional phrases). If a participant decided to change the initial answer, his or her first choice was coded as it reflected the initial preference. Measures used in the analyses of online data were based on reading times and number of relevant events on the entire sentence region, as well as on initially selected areas of interest or AoIs (an NP segment and a 
disambiguation segment). The measures were thus as follows: total reading time (ms), total fixation duration (ms), first pass (ms), $N$ of fixations, $N$ of regressions.

These eye-movements data have been gathered and preprocessed in the SMI BeGaze programme, and afterwards statistically analysed using rmANOVA and $t$-tests. Parametric statistics methods were used as the results were normally distributed. Repeated measures ANOVA was conducted for each of the mentioned measures on both AoIs, with two factors, each having two levels (2x2 design): 1) type of $N P$ (non-prepositional genitive NP vs prepositional phrase NP) and attachment site (N1 and N2) for the first experiment, and 2) animacy (attachment to animate vs attachment to inanimate noun within the NP) and attachment site (N1 and N2).

The results of the offline experiment point to the strong N1 attachment preference for both types of NPs. The percentage of N1 responses in the questionnaire was 70,3\% for nonprepositional genitive forms and $81,1 \%$ for prepositional phrases within the NP.

The online eye-tracking data in general showed longer reading times in stimuli with forced N2 than with forced N1 attachment for the entire sentence region and for the observed AoIs, indicating higher processing costs for $\mathrm{N} 2$ attachment in Croatian. Again, this happened irrespective of the type of NP. The second online experiment additionally revealed that animacy facilitates processing, nevertheless the attachment preference remained the same (N1).

More specifically, statistically significant main effects have been obtained for both factors, but they were stronger for the attachment site than for the other factor in both experiments. Still, significant main effects of animacy have been obtained on multiple dependent variables (i.e., longer reading times and higher processing costs for the inanimate than the animate attachment conditions) in the second online experiment.

Rather important is the finding that significant effects have been attained not only for the so called late measures (i.e., total reading times), but also for the early eye-tracking measures (i.e., first pass reading times), indicating several things: 1) the processor grasps relevant information in a rapid, automatized fashion; 2) attachment happens incrementally, but also 3) speakers rely on multiple levels of information early in the process. Qualitative data further corroborate these claims since they imply that speakers rely on multiple information when interpreting an utterance and making the sense of it. 
Together these results allowed for the acceptance of the $\mathrm{H1}$, the rejection of the $\mathrm{H} 2$, and partial acceptance of the $\mathrm{H3}$.

To sum up the overall results, in the broader psycholinguistic perspective they add the following:

- they refute some of the postulates of the construal thus emphasising its limitations;

- they somewhat confirm the proposals of interactive models which favour the idea of rapid activation of multiple levels of analyses during reading / sentence processing / attachment and disambiguation.

In the language-specific context they add the following:

- they show that the information integration during RC processing in Croatian is somewhat more natural in the case of $\mathrm{N} 1$ attachment than in the case of $\mathrm{N} 2$ attachment;

- they indicate that animacy can facilitate processing in Croatian - if the two antecedents (N1 and N2) differ in the animacy feature, processing will be eased if the subsequent clause modifies the animate antecedent.

The results on the preferred N1 attachment are in line with previous attachment preference studies in Croatian, but also show that the reasons are not strictly related to prosodic cues, as previously reported (i.e., Lovrić, Bradley \& Fodor, 2001; Lovrić, 2003). They are related also to the complex structural-semantic relations, as well as to the notion of dominance and prominence of the first mentioned referent in Croatian. The outcome that animacy facilitates processing, even though it does not lead to the change in attachment preference, is an important follow-up of the experiments on the factors that drive syntactic processing in Croatian, mostly agreement (Willer-Gold er al., 2016; Matić et al., 2019). Furthermore, the results support the rapid interaction of multiple levels (or cues) during syntactic processing - prosodic, structural, semantic, information (Erteschik-Shir, 2009), which are not easily distinguished or isolated.

There are certain limitations to this study that should be taken into account while designing similar research in the future. Even though there is a firm theoretical and psycholinguistic rationale for using relative clauses when studying attachment preference across languages, despite their importance findings cannot be easily generalised to other structures. This is why studies of this sort should aim at investigating and analysing also other structures. Moreover, in this research working memory capacity task served as the means of homogenising the initial sample of participants, as it is known that different levels of working memory capacity can cause differences in attachment preferences. Still, in order to broaden psycholinguistic insights 
further research should aim at investigating the influence of working memory capacity on attachment preferences, i.e., to determine the exact direction of the influence. That might be important since the findings on this matter are not just different, but completely contradictory (Swets et al., 2007; Traxler, 2007).

Finally, mainly young student population without language impairment has been involved in this study. It might be useful to examine how older speakers and speakers with language impairment interpret these types of structures, i.e. whether they rely on the same underlying mechanisms, when these processes happen and whether their attachment preferences differ from those of typical population.

Key words: psycholinguistic approach, syntactic processing, attachment preferences, relative clauses, construal hypothesis, structural-semantic factors. 


\section{UVOD}

\subsection{Pregled stanja u području}

Sintaktička obrada (izv. eng. syntactic processing) podrazumijeva procese uključene $\mathrm{u}$ izgradnju sintaktičkih struktura tijekom razumijevanja i proizvodnje jezika (Van Gompel i Pickering, 2007) koji se protežu u vremenu i međusobno nadograđuju, ali koji, unatoč brojnim istraživanjima, ostaju nerazjašnjeni. Pojedini autori (primjerice, Frazier i Fodor, 1978; Frazier i Rayner, 1982) sintaktičku obradu smatraju isključivo analizom strukturne razine rečenice koja se odvija neovisno o analizi značenja, zbog čega ju strogo razdvajaju od pojma obrada značenja (izv. eng. semantic processing) kojim podrazumijevaju naknadno oslanjanje na značenjske i pragmatičke čimbenike kojima govornik dolazi do konačnoga razumijevanja rečenice. Upravo je priroda tog odnosa, odnosno pitanje neovisnosti navedenih razina, predmetom rasprava u kognitivnoj psihologiji i psiholingvistici još od sredine prošloga stoljeća i, kao takvo, ishodištem brojnih teorijskih pristupa. U literaturi se tako najčešće upotrebljava upravo pojam syntactic processing ili, ako se izrijekom želi istaknuti automatska razina (strukturne) obrade jezika, parsing. ${ }^{1} \mathrm{U}$ ovome će se radu zadržati pojam sintaktička obrada, pri čemu on neće upućivati na odvojenost strukturne i značenjske razine. U slučaju potrebe za isticanjem jedne ili druge, to će biti posebno naglašeno.

I danas se nastoji odgovoriti na pitanja poput: Što pokreće sintaktičku obradu? Na koje se obavijesti u tom procesu govornici oslanjaju i u kojem trenutku? O kojim jezičnim i nejezičnim čimbenicima sintaktička obrada ovisi te postoje li međujezične, unutarjezične i individualne razlike? (Papadopoulou, 2006).

Početni deskriptivni pristupi jezičnim pojavnostima, iako zahtjevni i itekako vrijedni, pokazali su se nedostatnima. Iz toga su se razloga počele provoditi složenije studije i pojavljivati različite teorijske struje. S obzirom na raznolikost i složenost jezičnih pojavnosti, brojnost novonastalih teorija i pristupa unazad nekoliko desetljeća ne treba čuditi (Van Valin, 2001: 224). Jednako tako, tijekom godina su razvijeni i brojni modeli sintaktičke obrade. Tradicionalne su podjele s obzirom na način organizacije razina obavijesti (modularni i interaktivni modeli) i s obzirom

\footnotetext{
${ }^{1}$ Terminološka su određenja uvijek donekle sporna. Prenošenje terminologije i sklonost njezinomu ujednačavanju s jedne strane omogućava međusobnu razumljivost stručnjaka u području, a s druge je počesto uzrokom gubitka nijansiranosti u značenju među jezicima. Pojam parsing je ipak u ovome kontekstu nezahvalno prevesti na hrvatski jezik. Parsiranje je opravdan naziv kada se govori o strojno-potpomognutoj korpusnoj analizi, odnosno o strojnoj sintaktičkoj analizi prirodnoga jezika (Agić, 2012). Parsanje pak nije u skladu s tvorbom riječi sa stranom osnovom u hrvatskome, a osim toga ne sadržava nužno leksikološko značenje procesualnosti i neprekidnosti (Babić, 2002; Auburger, 2015).
} 
na vremenski slijed njihovom pristupanju (serijalni i paralelni modeli). Ti su modeli, dakako, odraz širih trendova u teorijskim pristupima te su podjednako zahvaćali i druge dijelove tumačenja funkcioniranja jezika. Modularni (ujedno i serijalni) modeli pretpostavljaju da se um sastoji od zasebnih modula od kojih je svaki uključen u specifične procese (Fodor, 1983) te da obrada na strukturnoj razini prethodi obradi značenja (izv. eng. syntax first). Interaktivni (paralelni) modeli pretpostavljaju istovremenu obradu strukturne i značenjske razine (MacDonald, Pearlmutter i Seidenberg, 1994). O sprezi tih dviju razina govorio je i Tesnière (1988), naglašavajući da značenjska razina mora biti izražena u strukturnoj.

Navedeni su modeli važni iz perspektive načina pristupanja razinama obavijesti, ali nedovoljno razmatraju obilježja struktura i njihov utjecaj na obradu. Upravo su se iz ovih razloga posljednjih godina počela provoditi kontrolirana psiholingvistička istraživanja koja su se usmjerila na proučavanje konkretnijih čimbenika koji u pojedinim jezicima uvjetuju sličnosti i razlike u sintaktičkoj obradi. U promišljanjima o jezičnim strukturama koje bi se sustavno mogle primjenjivati u međujezičnim istraživanjima sintaktičke obrade, dvosmislene su rečenice prepoznate kao vrlo zahvalna građa. Iako dvosmislenost obuhvaća sve iskaze koji omogućavaju višestruku interpretaciju s obzirom na jezični i situacijski kontekst (Van Gompel i Pickering, 2007: 290; Raffaelli, 2015: 267), odnosne se rečenice smatraju „idealnom građom za ispitivanje sintaktičke obrade i varijacija među jezicima iz razloga što se dvosmislenost u odnosnim rečenicama može javiti u većini jezika“" (Cuetos, Mitchell i Corley, 1996: 148). Osim toga, ispitivanjem takvih rečenica može se proniknuti u jezične čimbenike koji utječu na obradu rečenice u slučaju kad smisao nije dostupan iz konteksta (vidi i Raffaelli, 2015: 266-267). Iz navedenih se razloga započelo s proučavanjem načina na koji govornici različitih jezika tumače dvosmislene strukture, točnije dvosmislene odnosne rečenice iz kojih nije razvidno na koju se imenicu unutar složene imenske skupine (NP) odnosna surečenica odnosi (Hemforth, Konieczny i Scheepers, 2000a). Ova istraživanja preferencija vezivanja (izv. eng. attachment preference) najčešće se provode u odgođenom i stvarnom vremenu, odnosno upitnicima sa zadatcima prosudbe o tome koju od dviju riječi odnosna surečenica modificira te metodama poput čitanja vlastitom brzinom (izv. eng. self paced reading) i praćenja pokreta očiju (izv. eng. eye-tracking) tijekom čitanja.

Jednim od najznačajnijih psiholingvističkih istraživanja u tom kontekstu smatra se ono provedeno u španjolskome jeziku (Cuetos i Mitchell, 1988) jer je njime prvi put dokazano da 
se sintaktička obrada govornika toga jezika razlikuje od one govornika engleskoga. Ta i slična međujezična istraživanja počela su dovoditi u pitanje postavke postojećih univerzalnih modela. ${ }^{2}$ Posebno su se dvojbenima pokazali modularni modeli prema kojima se riječi u rečenici uvijek vežu na posljednju surečenicu što se definira kao lokalna/bliska preferencija (izv. eng. local attachment). Ta je preferencija, primjerice, potvrđena $\mathrm{u}$ norveškome, rumunjskome $\mathrm{i}$ švedskome jeziku (Ehrlich, 1999), a nelokalna/dalja u nizozemskome (Brysbaert i Mitchell, 1996), njemačkome (Hemforth i sur., 2000b), grčkome (Papadopoulou i Clahsen, 2003) i francuskome jeziku (Zagar, Pynte i Rativeau, 1997). Lovrić (2003) je, usmjeravajući se isključivo na prozodijske čimbenike u segmentaciji iskaza, pokazao da je tako i u hrvatskome. Razlike u metodologiji i istraživačkim nacrtima otežale su donošenje zaključaka o uzrocima razlika u obradi u različitim jezicima, zbog čega su razvijene razne pretpostavke koje se u mnogočemu razlikuju u svojim ishodišnim postavkama (vidi Fernández, 2003).

Konstrualna hipoteza ${ }^{3}$ (izv. eng. construal; Frazier i Clifton, 1996) kao mogući uzrok razlikama u sintaktičkoj obradi i preferencijama navodi strukturno-značenjske odnose među imenicama u složenoj imenskoj skupini (NP) koja prethodi odnosnoj surečenici. Ako su imenice u NP dio genitivne dopune, vezivanje će odnosnih surečenica koje slijede ovisiti o vrstama tih dopuna i izražavanju odnosa unutar NP, a što može varirati u jezicima (n.b. u engleskome prijedlog of odgovara hrvatskome genitivu, čija je tvorba u pravilu besprijedložna: podrum stana koji, otac moga prijatelja koji). Ipak, neovisno o preferencijama, imenice koje su dijelom genitivne dopune pripadaju istoj domeni obrade, to jest najčešće čine jednu obradbenu cjelinu. S druge strane, ako su imenice dio prijedložno-padežnog izraza, prijedlog će imati mogućnost tematskog označavanja i prebacivanja fokusa govornika (Frazier i Clifton, 1996: 73), zbog čega se u svim jezicima predviđa preferencija prema drugoj imenici unutar složene NP (eng. with, on; u hrvatskome: haljina s čipkom koja; žlijeb na krovu koji). Budući da se u kontekstu konstrualne hipoteze razlike u sintaktičkoj obradi i preferencijama vezivanja objašnjavaju upravo navedenim tipovima struktura, iste predstoji uključiti i u istraživanje preferencija $u$ hrvatskome.

U hrvatskome su jeziku NP unutar glavne surečenice najčešće upravo u genitivnim dopunama (Kuna, 2003) i prijedložno-padežnim izrazima, pri čemu su genitivni odnosi posebno složeni jer uključuju veliki značenjski raspon - mogu označavati posvojnost, atribuciju, rodbinske

\footnotetext{
${ }^{2}$ Istraživanja preferencija govornika samo su jedna u nizu brojnih istraživanja u intenzivnom razdoblju razvoja kognitivne psihologije i psiholingvistike sredinom i krajem prošloga stoljeća.

${ }^{3} \mathrm{Ne}$ odnosi se na hipotezu o gradbi značenja u okviru kognitivne lingvistike.
} 
odnose (Matasović, 2002). Široki raspon interpretacija odnosa pod utjecajem je znanja o svijetu, odnosa dio-cjelina, živo-neživo te ne postoji jedinstveni pristup koji bi obuhvatio sve situacije (Kuna, 2003). Te je odnose stoga potrebno posebno ispitati poštujući strukturu hrvatskoga jezika. Nadalje, druga pretpostavka u okviru konstrualne hipoteze, ona o drugačijoj obradi u slučaju kad NP sadrži prijedlog s mogućnošću tematskog označavanja i prebacivanja fokusa govornika, implicira vezivanje na drugu imenicu zanemarujući ostale čimbenike koji mogu utjecati na obradu rečenice, zbog čega ju valja pomnije istražiti (Papadopoulou, 2006; Hemforth i sur., 2015). Unatoč činjenici da je konstrualna hipoteza među prvima počela razmatrati značenjske čimbenike u obradi te njihov doprinos razlikama među jezicima, u svojim je dosezima donekle ograničena i nedostatna. To se primjerice ogleda u nesustavnom uvođenju nazivlja koje implicira važnost obavijesnoga u iskazu (poput fokus ili domena obrade), kao i u nedovoljno jasnim odrednicama i pojašnjenjima određenih pojavnosti. ${ }^{4}$

Upravo će pitanje preferencija vezivanja u odnosnim rečenicama u kojima relativizatoru prethode genitivne dopune i prijedložno-padežni izrazi biti predmetom istraživanja u ovoj disertaciji. Pritom će se kritički pristupiti modelima i prethodnim istraživanjima, a dobivene će se spoznaje i rezultati raspraviti u jezično-specifičnom kontekstu, odnosno u kontekstu hrvatskoga jezika i njegovih struktura.

Uočene različitosti u pristupu problematici sintaktičke obrade i čimbenicima koji ju uvjetuju, brojne nesustavnosti u primijenjenoj istraživačkoj metodologiji, kao i očito postojanje međujezičnih, unutarjezičnih i individualnih razlika u obradi, nametnuli su potrebu za novim istraživanjima (Hemforth i sur., 2000a; 2015). U njihovoj je provedbi vrlo važno kontrolirati počesto zanemarene nejezične (primjerice, raspon radnoga pamćenja) i jezične čimbenike (primjerice, strukturno-značenjski odnosi) te širenju spoznaja o sintaktičkoj obradi doprinijeti prikupljanjem građe u različitim jezicima, poštujući njihove osobitosti.

\footnotetext{
${ }^{4}$ Više u poglavlju 4.3. Kritički osvrt i nedostatci konstrualne hipoteze na 42. stranici ove disertacije.
} 


\subsection{Osvrt i motivacija za istraživanjem}

Psiholingvistička istraživanja u različitim jezicima u posljednja su se četiri desetljeća mahom usmjerila na proučavanje sličnosti i razlika u obradi među jezicima. Istraživanjima se tako s jedne strane određuju pravilnosti i dosljednosti u dobivenim spoznajama, a s druge strane čimbenici koji u pojedinome jeziku uvjetuju drugačiju pojavnost u odnosu na spoznaje u drugim jezicima. Takvim se studijama ispituju dotad predložene teorije sintaktičke obrade i njima pripadajući modeli, a kao rezultat širenja spoznaja predlažu se novi modeli. Taj pristup nalikuje slaganju jezičnoga mozaika, ali se u nagloj ekspanziji teorija i modela postaje sve teže snaći. Novopredloženi su modeli često usmjereni samo na jedan segment obrade i jednu vrstu građe, pri čemu zanemaruju spoznaje iz drugih modela, a posebice jezično-specifična obilježja i njihov utjecaj na obradu. Osim toga, samom provedbom istraživanja često prestaju daljnji postupci čime izostaje krajnji korak, a to je doprinos psiholingvističkom, ali i općelingvističkom te jezično-specifičnom kontekstu (Slika 1).

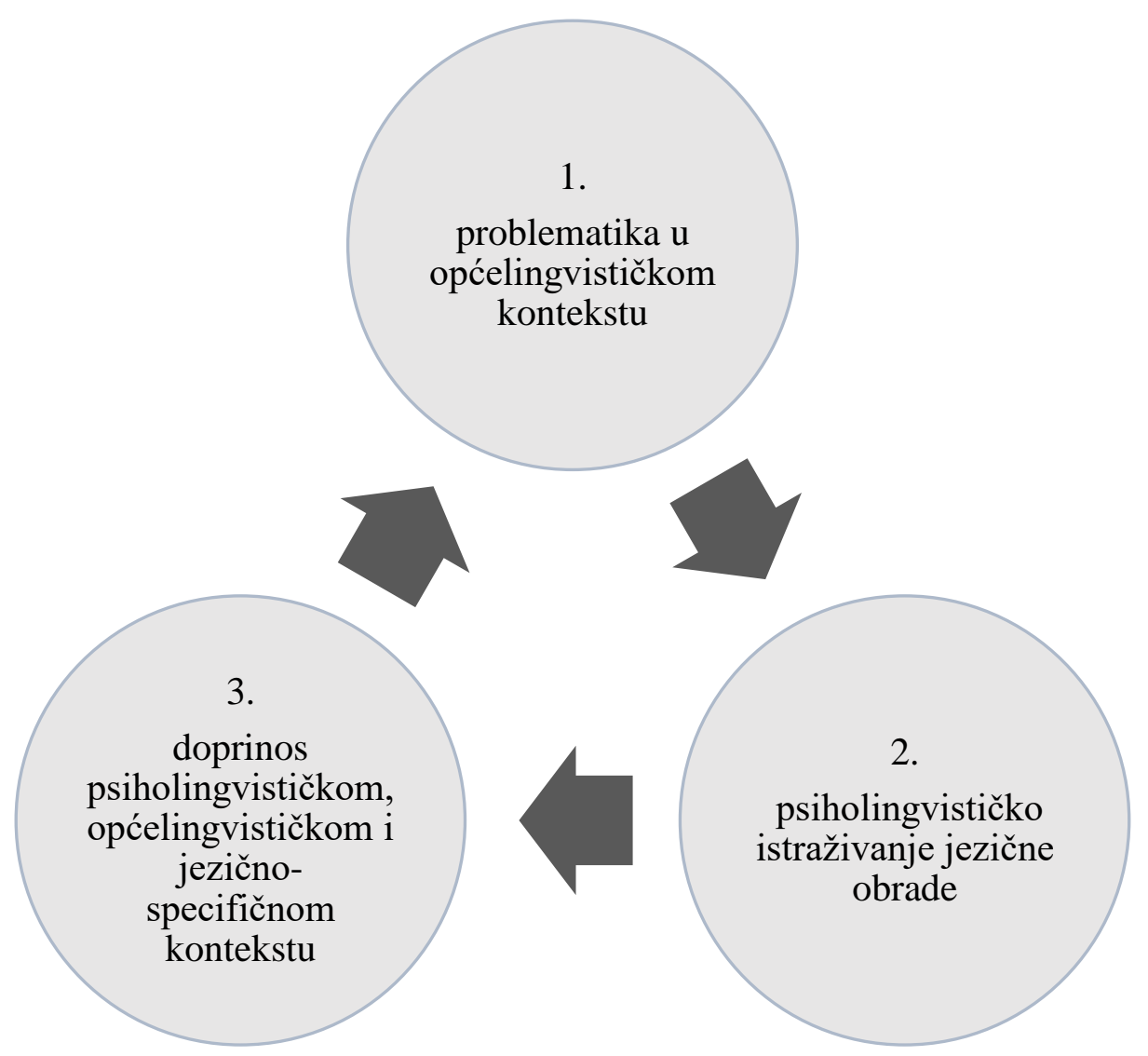

Slika 1. Proces psiholingvističkog istraživanja, od problematike do krajnjega doprinosa. 
Postojanje mnoštva teorija i modela umnogome usložnjava daljnja istraživanja, kako na konceptualnoj, tako i na izvedbenoj razini. Ipak, pregledom relevantnih znanstvenih radova uočava se nekoliko činjenica i znanstveno-istraživačkih tendencija: 1) postupno se pojavila svijest da nekad zagovarani univerzalni principi ustanovljeni mahom u engleskome jeziku ne vrijede u svim jezicima zbog čega se nametnula potreba za drugačijim objašnjenjima jezičnih pojavnosti; 2) javljaju se pokušaji sužavanja postavki univerzalnih modela kako bi se ipak opravdala njihova vjerodostojnost i osigurao njihov opstanak nakon što je utvrđeno postojanje jezika i/ili jezičnog fenomena koje ne mogu objasniti; 3) sve su veća nastojanja da se protumače pojedinačni jezični fenomeni s ciljem uvođenja sustava u novonastali teorijski kaos, bez obzira hoće li to rezultirati jednim sveobuhvatnim modelom jezične obrade ili mnoštvom malih, rascjepkanih djelića jezičnoga mozaika; 4) dobivene se spoznaje tek sporadično razmatraju ako se uklapaju u postojeći model, dok u suprotnome daljnje rasprave počesto prestaju.

Kako bi međujezične psiholingvističke studije kojima se ispituju određene jezične pojavnosti bile vjerodostojne, zaključujemo da je na umu potrebno imati nekoliko važnih činjenica:

1) Studije bi trebale biti međusobno usporedive, odnosno trebalo bi težiti ispitivanju sličnih struktura u jezicima, pritom poštujući zakonitosti jezika u kojemu se istražuje. ${ }^{5}$ Pristup istraživanju kojim se strukturna obilježja pojedinoga jezika narušavaju i prilagođavaju modelu s ciljem njegova ispitivanja/dokazivanja pogrešan je i dovodi do manjkavih spoznaja. S druge je strane jednako važno poštovati nacrt eksperimenta te ostaviti otvorenom mogućnost za valjane analize i međujezične usporedbe.

2) U psiholingvističkom je istraživanju jezični fenomen važno promatrati ,iz ptičje perspektive“, uvažavajući postavke postojećih modela i spoznaja, a ne ih zanemarivati uslijed teorijske ili istraživačke pristranosti (izv. eng. theoretical and experimenter bias). ${ }^{6}$

3) Novije spoznaje o međuovisnosti čimbenika koji utječu na sintaktičku obradu dodatno usložnjavaju sliku jezične obrade i uvjetuju nove metodološke kontrole prilikom ispitivanja. U istraživanjima je stoga važno pripaziti na jezične (primjerice, specifičnosti ispitanih struktura), ali i nejezične čimbenike (primjerice, individualne razlike govornika).

\footnotetext{
${ }^{5}$ Naime, naizgled jednake strukture u različitim jezicima mogu imati drugačiju funkciju.

${ }^{6}$ Istraživačka se pristranost može odnositi na pristranost prilikom izrade podražaja, odabira građe ili sudionika, analize rezultata i sl. (Forster, 2000; Skopeteas, 2012; Kuperman, 2015; vidi i Pojmovnik na kraju ovoga rada).
} 
Navedene teorijsko-metodološke postavke nije jednostavno pomiriti. Unatoč tomu, širenju se spoznaja može doprinijeti isključivo prikupljanjem građe u vlastitome jeziku, i to variranjem ili kontroliranjem nejezičnih i jezičnih čimbenika koji s obzirom na zakonitosti toga jezika mogu biti odlučujući čimbenici u obradi. Jedino se na temeljit i nepristran način može otvoriti put višestrukim zaključcima o sintaktičkoj obradi i početi graditi slika sintaktičke obrade, ako već postoji silna tendencija za time (Hemforth i sur., 1998; 2015). Ova disertacija ima upravo takav pristup, s ciljem dobivanja novih spoznaja o sintaktičkoj obradi u hrvatskome te utvrđivanja strukturno-značenjskih čimbenika s kojima se ona može dovesti u vezu. 


\subsection{Struktura rada}

Struktura disertacije slijedi iznesenu problematiku. Na početku rada prikazani su modeli sintaktičke obrade, s naglaskom na više mogućih načina njihove podjele i više mogućnosti pristupa problematici obrade rečenica. Prikaz tradicionalnih modela završava kritičkim osvrtom na njihove dosege i ograničenja te prikazom novijih načina proučavanja mehanizma sintaktičke obrade u različitim jezicima.

Novi se pristup proučavanju sintaktičke obrade odnosi na ispitivanje preferencija koje izvorni govornici imaju prilikom čitanja i tumačenja prvenstveno odnosnih rečenica, budući da one dozvoljavaju međujezične usporedbe, omogućavaju dvosmislenost, ali i eksperimentalnu manipulaciju s krajnjim ciljem donošenja valjanih i usporedivih zaključaka o sintaktičkoj obradi (Cuetos i sur., 1996). S obzirom da ishodišni model (konstrualna hipoteza; Frazier i Clifton, 1996) pretpostavlja da razlike u sintaktičkoj obradi navedenih struktura proizlaze prvenstveno iz različitih načina izražavanja odnosa antecedenata koji prethode relativizatoru, u središnjem su dijelu rada opisana obilježja hrvatske sintakse relevatna za tematiku, primjerice obilježja gramatičkoga i obavijesnoga ustroja, obilježja odnosnih rečenica te složenih genitivnih dopuna i prijedložno-padežnih izraza. Potom su prikazani ostali čimbenici koje je nužno uključiti u istraživanje fenomena sintaktičke obrade kako bi ono bilo što je moguće više kontrolirano, tj. kako bi rezultati bili vjerodostojni, a zaključci valjani. To se prvenstveno odnosi na raspon radnoga pamćenja govornika i obilježja jezičnih struktura poput čestotnosti, položaja, živosti i sl.

Nakon teorijskoga prikaza s kritičkim osvrtom na modele i prijašnja istraživanja, u drugome su dijelu rada prikazana istraživanja u odgođenom (upitnik) i stvarnom vremenu (metoda praćenja pokreta očiju) kojima su se u ovoj disertaciji ispitali mehanizmi obrade odnosnih rečenica $u$ hrvatskome. Naglasak je stavljen na strukturno-značenjske osobitosti imenskih skupina koje prethode odnosnoj zamjenici, a koje prema konstrualnoj hipotezi imaju utjecaj na obradu i tumačenje rečenica. Izložen je cilj, istraživačko pitanje i pretpostavke istraživanja, a potom metodološki postupak i eksperimentalni nacrt koji s jedne strane slijedi iz ishodišnoga modela, a s druge strane pomiruje manjkavosti uočene pregledom sličnih provedenih istraživanja. Potom su predstavljeni rezultati, a spoznaje su dovedene u vezu s istraživačkim pitanjem $u$ okviru ishodišnoga modela, kao i s drugim teorijskim pristupima te zakonitostima hrvatskoga jezika i njegovih struktura. 
Narav ovog istraživanja podrazumijeva psiholingvistički pristup (spoj teorijskoga i eksperimentalnoga) koji može omogućiti uvid u mehanizme obrade jezičnih struktura ali i - što je kudikamo važnije - odgovoriti na pitanja koja se tiču ispitanih jezičnih struktura u hrvatskome, kako bi se objasnio upravo njihov utjecaj na obradu. Na samome se kraju stoga donose temeljni zaključci, predlažu nove analize te prikazuju nedostatci i mogućnosti daljnje razrade ove složene tematike. Zbog nedovoljno razvijenoga hrvatskoga nazivlja u području psiholingvistike, tijekom nastanka ovoga rada razvijao se pojmovnik. 


\section{SINTAKTIČKA OBRADA I MODELI SINTAKTIČKE OBRADE}

Sintaktička obrada podrazumijeva inkrementalne, tj. međusobno nadograđujuće procese koji omogućavaju da čitatelj/slušatelj sintaktičku strukturu gradi u trenutku čitanja/slušanja, ne čekajući završetak rečenice ili fraze kako bi došao do njezine konačne interpretacije (Van Gompel i Pickering, 2007). U suprotnome bi i komunikacijski proces bio otežan, usporen i neekonomičan.

Cilj bilo koje cjelovite teorije sintaktičke obrade bio bi ustanoviti tijek procesa kojim govornici, od trenutka započinjanja čitanja ili slušanja rečenice, dolaze do konačne interpretacije, odnosno tumačenja njezina značenja. Zbog složenosti ove problematike i brojnih mogućnosti njezinomu pristupanju, tijekom godina su razvijeni razni modeli sintaktičke obrade. Pojedini se autori odlučuju na podjelu modela i teorija s obzirom na univerzalnost u mehanizmima sintaktičke obrade, drugi na podjelu s obzirom na vremenski slijed u pristupanju razinama obavijesti prilikom obrade, a neki se pak usmjeravaju na način organizacije razina obavijesti (Fernández, 2003; Papadopoulou, 2006; Eysenck i Keane, 2015). Kako se takvim razgraničenjima zanemaruju ostala obilježja u pozadini sintaktičke obrade, u ovom će se poglavlju modeli sintaktičke obrade opisati s obzirom na svoja sveukupna obilježja, bez strogih i isključujućih razgraničenja.

U nastavku stoga slijedi prikaz tradicionalnih podjela i s obzirom na način organizacije razina obavijesti (modularni i interaktivni modeli) i s obzirom na vremenski slijed njihovu pristupanju (serijalni i paralelni modeli). 


\subsection{Modularni (serijalni) modeli}

Modularni modeli sintaktičke obrade slijede iz višestoljetnih ideja o modularnosti uma koje svoje začetke nalaze u novovjekovnoj filozofiji 17. stoljeća sa začetnikom Renéom Descartesom, a kasnije i u različitim psihološkim i lingvističkim pravcima ${ }^{7}$. Prema takvim se idejama um sastoji od zasebnih modula od kojih je svaki uključen u specifične odijeljene procese. U kontekstu jezične obrade, modularni modeli podrazumijevaju odvojenost strukturne razine obrade od obrade značenja rečenice, odnosno postojanje posebnih modula za svaku od razina (Fodor, 1983). Ti su modeli ujedno i serijalni jer predmnijevaju da obrada na strukturnoj razini prethodi obradi značenja, što se u literaturi uobičajeno naziva syntax first.

Najutjecajniji modularni model od 70-ih godina prošloga stoljeća jest model vijugavoga puta (izv. eng. garden path; Frazier i Fodor, 1978; Frazier, 1979). Prema postavkama toga modela sve nestrukturne obavijesti (značenjska obilježja, kontekst, čestotnost uporabe oblika) postaju dostupne za obradu tek nakon što je prva razina obrade (struktura, položaj sastavnica) dovršena (Frazier, 1987). Takozvana prednost strukture nad značenjem tumači se načelima minimalnoga vezanja (izv. eng. minimal attachment) i kasnoga zatvaranja (izv. eng. late closure) koja su navodno univerzalna, odnosno svojstvena svim jezicima.

Načelo minimalnoga vezanja implicira da je prilikom obrade poželjna ona struktura koja u interpretaciji podrazumijeva manje čvorova. ${ }^{8} \mathrm{Na}$ primjeru obrade složenih rečenica, zavisna bi se surečenica tako ugradila u glavnu vezivanjem na glavne imenske i glagolske strukture. Ovim su se načelom dugo tumačile pojavnosti prilikom obrade odnosnih rečenica s neizrečenom zamjenicom (i ponekih drugih struktura) mjerene u stvarnom vremenu, ali prvenstveno $\mathrm{u}$ engleskome jeziku. Začetke takvih istraživanja nalazimo u disertaciji Lyn Frazier (1979):

(1) The defendant (øwho was) examined by the lawyer turned out not to be reliable. ${ }^{9}$

[ hrv. Optuženik kojega je ispitao odvjetnik pokazao se nepouzdanim. ].

U istraživanjima obrade struktura poput ove pokazalo se da govornici engleskoga rečenicu (1) inicijalno obrađuju kao aktivnu strukturu jer takvo tumačenje podrazumijeva „manje čvorova“ i manje je zahtjevno za radno pamćenje. Drugim riječima, govornici rečenicu počinju

\footnotetext{
${ }^{7}$ Ideju o tome da um sadrži kategorije koje određuju strukturu jezika te način mišljenja sačuvao je u svojim djelima primjerice i N. A. Chomsky.

${ }^{8}$ U objašnjenjima modularnih modela prevladava generativističko pojmovlje, zbog čega se ono upotrebljava i u ovome radu, ali samo s ciljem razjašnjenja njihovih općih postavki.

${ }^{9}$ Kao što se vidi iz prijevoda rečenice (1), zbog strukturnih obilježja, u hrvatskome jeziku nema dvosmislenosti.
} 
razumijevati na način da je optuženik (izv. eng. defendant) nekoga ispitivao (izv. eng. examined). Ostatak rečenice ipak sugerira točnu interpretaciju - da je optuženika ispitao odvjetnik (izv. eng. lawyer). Mjerama u stvarnom vremenu pojavljuje se efekt ponovljenoga čitanja dijelova rečenice u kojima je došlo do pogrešne interpretacije prilikom prvoga čitanja, što je dokazom teškoća u obradi. Do sličnih su spoznaja u svojem istraživanju došli i Rayner i Pollatsek (1989). U tome su istraživanju govornici engleskoga rečenicu

(2a) The girl knew the answer was wrong.

[ hrv. Djevojka je znala (da je) odgovor pogrešan. ]

obrađivali tumačeći imenicu answer izravnim objektom glagola knew, što je rezultiralo značajno produljenim čitanjem u odnosu na rečenicu

(2b) The girl knew the answer by heart.

[ hrv. Djevojka je znala odgovor napamet. ],

u kojoj je takva interpretacija točna i u skladu s načelom minimalnog vezanja. ${ }^{10}$

Načelo minimalnoga vezanja nema značajnu ulogu u kontekstu teme ove disertacije koja je usmjerena na preferencije vezivanja u odnosnim rečenicama sa složenim imenskim skupinama koje prethode odnosnoj surečenici. Vodeći se terminologijom ovoga modela, vezivanje na obje imenice unutar NP iziskuje jednak broj čvorova. Iz toga se razloga o ovome načelu više neće raspravljati, ali se pregled istraživanja u kojima se ono razmatra može pronaći u Van Gompel i Pickering (2007) ili Eysenck i Keane (2015).

Važnije načelo u kontekstu preferencija vezivanja u odnosnim rečenicama jest načelo kasnoga zatvaranja prema kojemu se nove riječi u odnosnoj surečenici uvijek vežu na posljednju surečenicu, odnosno na riječ koja se upravo obrađuje. U rečenicama poput

(3) The steak with the sauce that was tasty didn't win the prize.

[ hrv. Odrezak s umakom koji je bio ukusan nije odnio pobjedu. ]

\footnotetext{
${ }^{10}$ Prijevodi na hrvatski jezik pokazuju da takve strukture nije moguće upotrijebiti kao ispitne podražaje za slična istraživanja u hrvatskome.
} 
model pretpostavlja univerzalna načela vezivanja na posljednju imenicu u imenskoj skupini, odnosno tumačenje rečenice (3) na način da je ukusan umak (izv. eng. sauce), a ne odrezak (izv. eng. steak) (preuzeto od Traxler, Pickering i Clifton, 1998).

Načelo kasnoga zatvaranja u okviru drugih pristupa naziva se i načelom recentnosti (izv. eng. recency; Gibson, 1998). Njegova je univerzalnost ozbiljno dovedena u pitanje naglim porastom broja istraživanja u drugim jezicima, o čemu će više riječi biti u poglavljima koja slijede (3.1. Načelo kasnoga zatvaranja u okviru modela vijugavoga puta). 


\subsection{Interaktivni (paralelni) modeli}

Interaktivni (ujedno i paralelni) modeli, za razliku od modularnih (serijalnih), pretpostavljaju istovremenu obradu strukturne i značenjske razine. Drugim riječima, govornici se prilikom obrade (čitanja ili slušanja rečenice) istovremeno oslanjaju na obje razine obavijesti. Takvi se modeli razvijaju u okviru teorija utemeljenih na ograničenjima ${ }^{11}$ (izv. eng. constraint-based theories; MacDonald i sur., 1994).

Prema njima su sve moguće interpretacije dvosmislenih rečenica istovremeno dohvatljive $u$ jednakoj mjeri. Kaže se da su interpretacije u kompeticiji te da će prevladati ona koja je u skladu s više različitih izvora obavijesti na koje se govornik jezika može osloniti (primjerice, čestotnost riječi u pojedinome jeziku ili rečenični i izvanrečenični kontekst ako ispitivanje uključuje rečenice u diskursu; vidi Altmann i Steedman, 1988; MacDonald i sur., 1994; McRae, SpiveyKnowlton i Tanenhaus, 1998; Spivey i Tanenhaus, 1998; Thornton, Gil i MacDonald, 1998; Van Gompel, Pickering i Traxler, 2000; Snedeker i Trueswell, 2004). Strukturni se izvori obavijesti, tj. ključevi koji olakšavaju interpretaciju (izv. eng. cues), među jezicima razlikuju (Bates i sur., 1982). Morfološko je označavanje tako znatno jači ključ u hrvatskome nego u engleskome jeziku u kojem je važniji redoslijed riječi u rečenici (vidi i Kuvač Kraljević, 2008).

Razvidno je da ovi modeli, za razliku od prethodnih, ne zagovaraju univerzalnost u sintaktičkoj obradi. Tijekom mjerenja obrade dvosmislenih rečenica u stvarnom vremenu predviđa se produljeno vrijeme čitanja do trenutka u kojem se jedna od aktiviranih interpretacija rečenice ne inhibira. Primjerice, ako odnosna surečenica istovremeno može modificirati obje imenice unutar imenske skupine koje joj prethode, prilikom čitanja će doći do kompeticije u obradi. ${ }^{12}$

Preferencije vezivanja prilikom obrade odnosnih rečenica, tj. čimbenici koji su zaista odlučujući u tumačenju odnosnih rečenica, u okviru ovih modela ni danas nisu utvrđeni. Upravo je to jedan od njihovih najvećih nedostataka (Rayner i sur., 2012; Eysenck i Keane, 2015).

\footnotetext{
${ }^{11}$ Pojam ograničenje u ovim se teorijama može smatrati istovjetnim pojmu pravilo jer označava dopuštene granice određenih postavki teorije (vidi i Katunar, 2015: 99).

${ }^{12}$ Pojmovlje kojim se opisuje sintaktička obrada počesto ima tehnički prizvuk (aktivacija, inhibicija, kompeticija), međutim to je neizbježno ako se u obzir uzmu kognitivna dimenzija obrade i eksperimentalni pristup kojim se često i dolazi do spoznaja u okvirima psiholingvistike.
} 


\subsection{Model neograničene utrke}

Model neograničene utrke (izv. eng. unrestricted race model; Van Gompel i sur., 2000) prvi se put spominje koncem 90-ih godina prošloga stoljeća. Van Gompel i suradnici su, potaknuti rezultatima opsežne meta-analize dotadašnjih istraživanja, predložili model sintaktičke obrade u skladu sa spoznajom da se dvosmislene odnosne rečenice obrađuju s manje obradbenoga napora od onih u kojima nema dvosmislenosti iz razloga što je modifikacija tada jasna. Takve su rezultate istraživanja u stvarnom vremenu obrazložili tvrdnjom da prilikom obrade zasigurno ne dolazi do kompeticije između razina obavijesti, već da govornik odmah gradi isključivo jednu interpretaciju rečenice. Model neograničene utrke stoga posjeduje obilježja i modularnih i interaktivnih modela, ali se od njih ujedno i bitno razlikuje. Sličnost se s interaktivnim modelima očituje u neograničenim mogućnostima oslanjanja na različite izvore obavijesti prilikom sintaktičke obrade. Iako različite mogućnosti interpretacije neće biti u kompeticiji te će uvijek prevladati jedna, ni ovaj model ne predviđa konkretne čimbenike koji to uvjetuju. Za razliku od interaktivnih i paralelnih modela, a donekle u skladu s modularnima i serijalnima, model sugerira da govornik odmah gradi isključivo jednu interpretaciju rečenice, odnosno da prilikom čitanja/slušanja ne razmatra alternativne mogućnosti, već gradnju strukture i značenja oblikuje na jedan način od trenutka započinjanja čitanja/slušanja. Tek ako se u kasnijim dijelovima rečenice pokaže da započeta interpretacija nije u skladu s onime kamo rečenica doista smjera, doći će do kratkog prekida u obradi (primjerice, do ponovnoga čitanja spornih dijelova rečenice). To je razlogom dulje obrade rečenica u kojima je modifikacija (vezivanje na prvu ili drugu imenicu unutar imenske skupine) jasna - jer postoji mogućnost da ona nije u skladu s govornikovim inicijalnim pretpostavkama.

Modelom neograničene utrke najčešće se uspoređuju dvosmislene i nedvosmislene rečenice te se analiziraju vremenski parametri obrade jednih i drugih, kako bi se dobio odgovor na pitanje u kojem je uvjetu čitanje brže, tj. obrada jednostavnija (Van Gompel i Pickering, 2007; Eysenck i Keane, 2015; Hemforth i sur., 2015). Traxler i sur. (1998) nizom su eksperimenata u stvarnom vremenu opovrgnuli dotadašnje syntax first, ali i njima oprečne interaktivne modele, te dobivenim spoznajama utrli put razvoju ovoga modela. Usporedbom obrade dvosmislenih odnosnih rečenica $\mathrm{i}$ onih u kojima postoji jasna modifikacija prve ili druge imenice unutar imenske skupine, pokazali su da nema naznaka kompeticiji u uvjetu dvosmislenosti. Dokazali 
su i razliku u obradi rečenica u kojima postoji vezivanje na prvu, odnosno drugu imenicu. ${ }^{13}$ Iako su autori doprinijeli razvoju spoznaja o vremenskim parametrima obrade, nisu u detalje razmatrali obilježja ispitanih struktura i uzroke dobivenih razlika. Različita mogućnost interpretacije rečenica nazvana je neograničenom utrkom u obradi, ali čimbenici koji uvjetuju konačnu interpretaciju ponovno nisu do kraja razjašnjeni.

Iako je ovaj model pomirio dvije suprotnosti u pristupu sintaktičkoj obradi, ipak „donekle pojednostavljuje sliku složenih mehanizama koji su u pozadini“ (Vasishth, 2017). Tome svjedoči i činjenica da ga se u literaturi naziva nedovoljno specifičnim modelom (Papadopoulou, 2006; Van Gompel i Pickering, 2007; Swets i sur., 2008; Vasishth, 2017). Velika mu je zamjerka što ne propituje konkretne čimbenike koji uvjetuju konačnu interpretaciju rečenice, već je usmjeren isključivo na vremensku komponentu obrade. Osim toga, sporni su i metodološki postupci istraživanja u okviru ovoga modela (Green i Mitchell, 2006; Swets, i sur., 2008; Vosse i Kempen, 2009) ${ }^{14}$. To su samo neki od razloga zbog kojih je i ovaj model nedostatan u kontekstu istraživanja međujezičnih razlika u preferencijama vezivanja na prvu ili drugu imenicu unutar imenske skupine.

\footnotetext{
${ }^{13}$ Takve su spoznaje dodatno potvrđene u istraživanjima Van Gompel i sur. $(2000 ; 2001 ; 2005)$ te Mohamed i Clifton (2011).

${ }^{14}$ Navedeni se autori priklanjaju onima koji zagovaraju interaktivnost u obradi.
} 


\subsection{Dosezi i ograničenja tradicionalnih modela}

Pitanja serijalnosti i paralelnosti u obradi te pitanja modularnosti i interaktivnosti ne omogućavaju jasna predviđanja preferencija govornika različitih jezika, kao ni o čemu će sintaktička obrada ovisiti. Iako je važnost tih modela neosporna zato što problematiziraju načine pristupanja razinama obavijesti tijekom obrade, oni ipak nedovoljno razmatraju, pa i zanemaruju, obilježja struktura i njihov utjecaj na obradu. Model vijugavoga puta donekle je imao jasne postavke predviđajući jednake preferencije vezivanja u svim jezicima i jezičnim strukturama, međutim načelo kasnoga zatvaranja krajem je 80-ih godina prošloga stoljeća osporeno uslijed razvoja eksperimentalnih metoda u psiholingvističkim istraživanjima i porasta broja međujezičnih istraživanja (Papadopoulou, 2006; Eysenck i Keane, 2015). Istraživački nacrti i podražaji u psiholingvističkim istraživanjima u engleskome u početku su se preslikavali $\mathrm{u}$ istraživanja u drugim jezicima, a spoznaje do kojih se došlo u tome jeziku neutemeljeno su se prihvaćale kao univerzalna istina. Doista, da su se istraživanja nastavila provoditi isključivo u engleskome jeziku ili podređivati njegovoj strukturi, vjerojatno ne bi došlo do napretka u spoznajama o jezičnoj obradi, odnosno do razvoja novih modela sintaktičke obrade.

Unatoč novijim pristupima još uvijek ne postoji jedinstveni model koji bi mogao objediniti spoznaje i utvrditi uzroke međujezičnih razlika, poput razlika u preferencijama govornika prilikom tumačenja naizgled jednakih struktura kao što su odnosne rečenice (Van Gompel i sur., 2000; Hemforth i sur., 2015). Dosadašnja nastojanja za tumačenjem ovih pojavnosti pokazala su se pogrešnima ili nepotpunima. Prema Mitchell i Brysbaert (1998) te Hemforth i sur. (2015) postojećim teorijama, njima pripadajućim modelima te eksperimentalnim nacrtima još uvijek nedostaje preciznosti i kontrole, zbog čega postoji stalna potreba za novim istraživanjima kojima će se premostiti nedostatci onih prethodnih. 


\section{PREFERENCIJE VEZIVANJA U ODNOSNIM REČENICAMA}

Za razliku od modela predstavljenih u prethodnome poglavlju, a koji su mahom usmjereni na vremenski slijed i način organizacije razina obavijesti te na pitanje univerzalnosti sintaktičke obrade, u ovome će se poglavlju prikazati modeli (ili njima pripadajuća načela i pretpostavke) koji su se u većoj mjeri počeli usmjeravati na obilježja struktura i razmatrati njihov utjecaj na sintaktičku obradu. Iz toga je razloga njihova važnost u objašnjenju preferencija vezivanja, međujezičnih razlika i unutarjezičnih čimbenika koji uvjetuju obradu, veća u odnosu na prethodno opisane modele.

Prvo će se prikazati načelo kasnoga zatvaranja u okviru modela vijugavoga puta, a potom i tri najpoznatije pretpostavke o sintaktičkoj obradi koje razmatraju preferencije vezivanja u odnosnim rečenicama: hipoteza implicitne prozodije, hipoteza ugađanja te konstrualna hipoteza. Posljednja je navedena hipoteza polazištem ovoga doktorskoga istraživanja i kao takva bit će posebno izdvojena i podrobnije opisana, odnosno bit će smještena više u hijerarhiji poglavlja. 


\subsection{Načelo kasnoga zatvaranja u okviru modela vijugavoga puta}

O modelu vijugavoga puta bilo je riječi u kontekstu modularnosti i serijalnosti u obradi, prilikom razmatranja načina na koji se tijekom jezične obrade pristupa različitim razinama obavijesti. Detaljniji je osvrt na postavke načela kasnoga zatvaranja u pozadini ovoga modela važan iz najmanje dva razloga. Prvo, narav istraživačkoga pitanja ove disertacije zahtijeva stjecanje cjelovite slike o povijesnom slijedu razvoja spoznaja koje su utjecale na oblikovanje novih, a čije začetke nalazimo upravo u opovrgavanju načela kasnoga zatvaranja. Nadalje, pregledom postavki toga načela dodatno će se opravdati odluka za uključivanjem odnosnih rečenica, a ne nekih drugih struktura, u istraživanje preferencija vezivanja općenito, a time i u ovoj disertaciji.

Načelo kasnoga zatvaranja dugo se smatralo svojevrsnim dokazom da je sintaktička obrada vođena općevažećim zakonima svojstvenima svim prirodnim jezicima (Frazier, 1979). Načelo podrazumijeva da se nove riječi u zavisnoj strukturi uvijek vežu na posljednju surečenicu ili frazu, odnosno na riječ koja se trenutno obrađuje (Frazier i Fodor, 1978; Frazier, 1979). To se uobičajeno naziva učinkom lokalnosti (izv. eng. locality effect), odnosno lokalnom ili bliskom preferencijom (izv. eng. local preference). Ako struktura rečenice ipak nije u skladu s onime što postavke načela nalažu, odnosno ako ih rečenica svojom strukturom narušava, doći će do teškoća u obradi (Fodor, 1998; vidi i Papadopoulou, 2006).

Predviđanja su se toga načela godinama ispitivala na strukturama koje su prihvatljive u engleskome jeziku zbog čega je svako sljedeće istraživanje samo iznova potvrdilo spoznaje onoga prethodnog. Neki od ispitnih podražaja (rečenica) u istraživanjima kojima je dokazano načelo kasnoga zatvaranja u engleskome jeziku jesu:

(4a) Since Jay always jogs a mile and a half this seems like a short distance to him.

[ hrv. Kako Jay uvijek trči milju i pol(,) to mu se čini malom udaljenošću. ]

(4b) Since Jay always jogs a mile and a half seems like a very short distance to him.

[ hrv. Kako Jay uvijek trči(,) milja i pol mu se čini malom udaljenošću. ].

Frazier i Rayner (1982) pratili su pokrete oka sudionika istraživanja, izvornih govornika engleskoga, a mjere u stvarnom vremenu pokazale su da čitatelji s manje obradbenoga napora obrađuju rečenicu (4a) nego rečenicu (4b). Govornici su u potonjoj rečenici imensku skupinu $a$ mile and $a$ half tumačili kao izravni objekt glagola jogs umjesto kao subjekt idućega glagola 
seems. Na ovaj je zaključak uputilo produljeno vrijeme čitanja glagola seems, kao i nesigurnost govornika u konačnom tumačenju rečenice.

Nadalje, u rečenici

(5) Jessie put the book Kathy was reading in the library.

[ hrv. Jessie je (o)stavila knjigu koju je Kathy čitala u knjižnici / knjižnicu. ]

prijedložni se izraz in the library može odnositi na glavnu surečenicu Jessie put, ali i na zavisnu surečenicu Kathy was reading, a višestruka je mogućnost interpretacije uzrokom dvosmislenosti čitave rečenice. Frazier i Fodor (1978) istraživanjem su potvrdili da su govornici engleskoga skloniji interpretaciji predviđenoj načelom kasnoga zatvaranja, odnosno vezivanju na zavisnu surečenicu. ${ }^{15}$

Uvidom u navedene strukture razvidno je da se iste ne mogu smatrati prikladnima u provedbi istraživanja u nekim drugim, strukturno drugačijim, jezicima. Iz toga razloga ispitivanja ograničena isključivo na strukture engleskoga jezika mogu dati pogrešnu sliku sintaktičke obrade. Primjerice, obrada će rečenica u engleskome ovisiti ponajviše o poretku riječi, što nije slučaj u flektivnim jezicima poput hrvatskoga u kojima je redoslijed riječi slobodniji. U skladu s time, strukture koje u engleskome mogu uzrokovati dvosmislenost, najčešće ju u morfološki bogatim jezicima ne uzrokuju.

Ispitivanje rečenica kao što su (4b) i (5) u hrvatskome je jeziku neosnovano jer padežni nastavci ne ostavljaju mjesto pogrešnoj interpretaciji. Naime, već je istaknut prijevod rečenice (4b) koja bi u hrvatskome jeziku glasila otprilike Kako Jay uvijek trči(,) milja i pol mu se čini malom udaljenošću. Padežni nastavak za nominativ (milja) sugerira interpretaciju i ne ostavlja mjesto alternativnom tumačenju. Interpretacija bi dakako bila drukčija da je u rečenici upotrijebljen padežni nastavak za akuzativ (milju). I u rečenici (5) padežni nastavci sugeriraju interpretaciju (lokativ $u$ knjižnici nasuprot akuzativu $u$ knjižnicu). Ne smije se zanemariti ni značajna uloga prozodijskih obilježja (Fodor, 2002; Frazier, Carlson i Clifton, 2006) i interpunkcije (Hill i Murray, 2000) u obradi rečenice, što je pitanje koje zadire i u metodološke odluke prilikom domišljanja i određivanja eksperimentalnih nacrta.

${ }^{15}$ Pregled sličnih istraživanja može se pronaći u Frazier (1987), Van Gompel i Pickering (2007) te Eysenck i Keane (2015) 
Krajem 80-ih godina prošloga stoljeća konačno su uslijedila istraživanja obrade odnosnih rečenica u drugim jezicima. Upravo su ta istraživanja počela dovoditi u pitanje rezultate studija u engleskome. Posebice se dvojbenim pokazalo načelo kasnoga zatvaranja kojim se u složenim rečenicama predviđa lokalna preferencija vezivanja na posljednju imenicu ili čitavu surečenicu. Istraživanje provedeno u španjolskome i engleskome jeziku (Cuetos i Mitchell, 1988) smatra se osobito važnim jer je njime prvi put utvrđeno da se sintaktička obrada govornika tih dvaju jezika razlikuje, odnosno da govornici strukturno različitih jezika naizgled jednake strukture ne obrađuju na jednak način. Ispitane su rečenice poput:

(6a) španj. El periodista entrevistó al hijo de coronel que estaba en el balcón.

(6b) eng. The journalist interviewed the son of the colonel who was on the balcony.

[ hrv. Novinar je intervjuirao sina øod pukovnika koji je bio na balkonu. ].

Utvrđeno je da govornici španjolskoga surečenicu koji je bio na balkonu (izv. španj. que estaba en el balcón) tumače kao modifikaciju prve imenice unutar imenske skupine (sina - hijo), a ne druge (pukovnika - coronel). Izvorni govornici engleskoga istu rečenicu tumače na drugačiji način, vodeći se načelom kasnoga zatvaranja.

Ovakva su se istraživanja preferencija vezivanja (izv. eng. attachment preference) ${ }^{16}$ počela provoditi na rečenicama koje omogućavaju višestruku interpretaciju ( $\mathrm{tj}$., dvosmislene su) jer u nedostatku izvanrečeničnoga konteksta nije u potpunosti jasno koju imenicu unutar imenske skupine odnosna surečenica modificira (Cuetos i sur., 1996; Hemforth i sur., 2000a; Papadopoulou, 2006). Dvosmislenost se u odnosnim rečenicama može javiti u većini jezika, stoga se upravo one smatraju ,idealnima za ispitivanje sintaktičke obrade i međujezičnih varijacija“ (Cuetos i sur., 1996: 148).

Propitivanje univerzalnosti u sintaktičkoj obradi, a s druge strane određivanje čimbenika koji u pojedinim jezicima dovode do drugačijih pojavnosti, uskoro je postalo temeljnim ciljem u okviru studija jezične obrade. O načinima provedbe takvih ispitivanja više će riječi biti u poglavlju 7. Načini ispitivanja preferencija vezivanja.

Iako su Cuetos i Mitchell (1988) svojim istraživanjem potaknuli nova pitanja i provedbu sličnih psiholingvističkih istraživanja, metodološke su nesustavnosti istraživačkih nacrta te

\footnotetext{
${ }^{16}$ Frazier i Clifton (1997: 289) govore i o preferencijama tumačenja odnosnih rečenica (izv. eng. RC interpretation preferences).
} 
heterogenost rezultata otežali donošenje zaključaka o konkretnim uzrocima međujezičnih razlika.

Tablica 1 prikazuje spoznaje o preferencijama vezivanja u različitim dosad istraženim jezicima, bez zadiranja u obilježja ispitanih struktura ili metodu kojom se došlo do rezultata. Strukturnoznačenjskim obilježjima ispitnih podražaja i ostalim čimbenicima koji utječu na sintaktičku obradu i preferencije vezivanja posvećeno je posebno poglavlje ove disertacije.

Tablica 1. Pregled preferencija vezivanja u različitim jezicima.

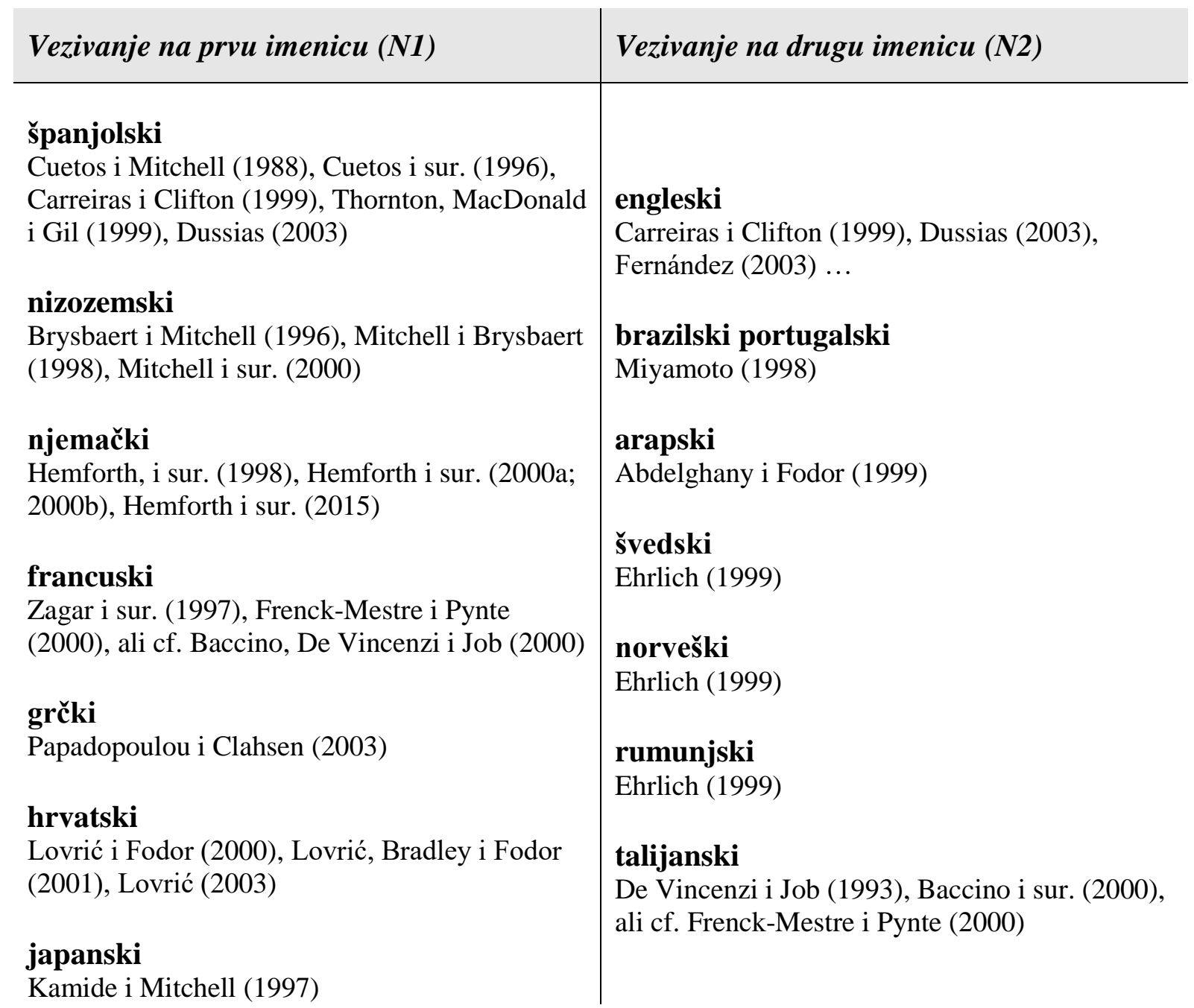

Napomena: Jezici su u tablici grupirani prema tome je li istraživanjem potvrđena preferencija vezivanja na prvu (N1) ili drugu imenicu (N2) unutar imenske skupine. 
Samim pogledom na Tablicu 1 i raspodjelu nastalu na temelju opsežnoga pregleda istraživanja postaje jasno da podatci ne govore gotovo ništa o obradi s obzirom na tipološka obilježja jezika. Primjerice, za talijanski i francuski jezik postoje različite spoznaje o sintaktičkoj obradi - oba bi jezika mogla pripadati skupini jezika s preferencijom vezivanja na prvu, ali i na drugu imenicu unutar NP (vidi De Vincenzi i Job, 1993 i Zagar i sur., 1997; ali cf. Baccino i sur., 2000 i Frenck-Mestre i Pynte, 2000). Uzroci oprečnih spoznaja najčešće leže u neujednačenim istraživačkim nacrtima, podražajima i metodama istraživanja (Fernández, 2003; Dussias i Sagarra, 2007). 


\subsection{Hipoteza ugađanja}

Hipoteza ugađanja (izv. eng. tuning hypothesis; Mitchell i sur., 1995) u središte stavlja utjecaj prethodnoga jezičnog iskustva na sintaktičku obradu. Temelji se na postavci da učestalost struktura u pojedinome jeziku u najvećoj mjeri uvjetuje način na koji se odvija sintaktička obrada. Iako i ova hipoteza razmatra prvenstveno strukturna obilježja rečenica, pritom ipak u obzir uzima i čestotnost njihova pojavljivanja. Ako je odnosna rečenica dvosmislena, što je najčešće slučaj u istraživanjima preferencija vezivanja, govornici će se prilikom njihova tumačenja voditi mogućnošću koja je izglednija u tome jeziku. Primjerice, ako je učestalija odnosna struktura u kojoj je prva imenica glavom, a ostale su joj podređene te odnosna surečenica modificira glavu imenske skupine, takva će najčešće biti i preferencija izvornih govornika. Optimalan način provjeravanja ove hipoteze jest dovođenje u vezu bihevioralnih istraživanja s podatcima iz korpusa (primjerice, Mitchell i sur., 1995; Desmet, De Baecke i Brysbaert, 2002).

Cuetos i sur. (1996) su, kako bi ispitali hipotezu ugađanja, u istraživanje uključili dvije skupine djece, pri čemu je pripadnost skupini ovisila o inicijalnim preferencijama, tj. o načinima na koji su djeca prije istraživanja tumačila dvosmislene strukture. Nakon što su ispitivači nekoliko dana djecu izlagali tekstovima zasićenima rečenicama $u$ kojima se odnosna surečenica nedvosmisleno odnosila isključivo na jednu od dviju imenica, provjeravali su hoće li se njihovo tumačenje u sljedećem ispitivanju promijeniti pod utjecajem iskustva. U jednoj je skupini promjena primijećena, dok su u drugoj dobiveni potpuno suprotni i neočekivani rezultati. U okviru hipoteze ugađanja provedeno je još nekoliko istraživanja od kojih su neka potvrdila njezine postavke (primjerice, Desmet i sur., 2002), a neka nisu (primjerice, Gibson i Schütze, 1999). Proturječni su rezultati problematični i otežavaju donošenje konkretnih zaključaka u okviru ove hipoteze.

Manjkavost je ovakvoga pristupa i oslanjanje na pretraživanja korpusne građe uz nedostatan uvid u značenjska obilježja struktura. Nadalje, tumačenje nekih drugih struktura nije ni u kakvoj korelaciji s korpusnim pretraživanjima, a hipoteza ugađanja ne nudi objašnjenje zašto je tomu tako. Naposljetku, same su studije dugotrajne, a građa i sadržaj korpusa u različitim jezicima neujednačeni, što otežava međujezične usporedbe i donošenje valjanih zaključaka o uzrocima i naravi međujezičnih razlika (Fernández, 2003). 


\subsection{Hipoteza implicitne prozodije}

Hipoteza implicitne prozodije (izv. eng. implicit prosody hypothesis; Fodor, 2002) temelji se na pretpostavci da prozodijska obilježja jezika uvjetuju sintaktičku obradu i način na koji govornici obrađuju odnosne rečenice, čak i prilikom čitanja u sebi. Prema Fodor (1998; 2002) govornik će se prilikom obrade odnosnih rečenica (i drugih struktura), tijekom čitanja voditi implicitno naučenim prozodijskim obilježjima vlastitoga jezika. Ta je pretpostavka nastala kao posljedica uviđanja da duljina rečenice $i$ način segmentacije podražaja $u$ ispitivanjima preferencija vezivanja značajno utječu na tumačenje rečenice, tj. određivanje antecedenta. Rezultati nekih istraživanja (primjerice, Lovrić i sur., 2001) potvrdili su značajnu korelaciju između duljine rečenice i načina njezina tumačenja. Lokalna je preferencija (vezivanje na drugu imenicu) češća ako su ispitni podražaji kratke odnosne rečenice, dok nelokalna preferencija (vezivanje na prvu imenicu) raste s porastom duljine rečenice. Tomu je tako jer je izglednije da će vrlo dugačka surečenica činiti posebnu i samostalnu prozodijsku jedinicu. Podatci o prirodnim prozodijskim obilježjima pojedinoga jezika i njihovom utjecaju na sintaktičku obradu mogu se prikupiti i detaljnim akustičkim analizama proizvodnje izvornih govornika, a potom usporedbom s rezultatima istraživanja obrade u stvarnom vremenu. Ipak, i tada je empirijski zahtjevno odrediti jesu li najranije faze sintaktičke obrade doista vođene prvenstveno prozodijskim čimbenicima ili ipak nekim drugim (Fernández, 2003).

Spoznaje o mogućem utjecaju suprasegmentalnih obilježja na sintaktičku obradu upućuju na mogućnost da interaktivnost u obradi seže i u govornu proizvodnju. To otvara put zaključku da je naše poimanje jezika i svijeta uvjetovano višestrukim, implicitno naučenim čimbenicima te da interaktivnost u obradi prelazi granice samoga jezika.

Ako se istraživanje i ne provodi u okviru hipoteze implicitne prozodije, njezine se postavke moraju imati na umu prilikom promišljanja o istraživačkom nacrtu i interpretaciji rezultata. Naime, budući da duljina rečenice i način prikazivanja podražaja mogu utjecati na odgovore sudionika, a posljedično i na zaključke o sintaktičkoj obradi, ove bi čimbenike svakako trebalo kontrolirati tijekom izrade nacrta. 


\subsection{Konstrualna hipoteza}

Konstrualna hipoteza (izv. eng. construal hypothesis; Frazier i Clifton, 1996), za razliku od ostalih pretpostavki i modela, jedina daje konkretna predviđanja o sintaktičkoj obradi i različitim preferencijama s obzirom na obilježja i vrstu sintaktičkih struktura. Iz toga je razloga upravo ona polazištem ovoga doktorskog istraživanja, a kao takva je i opisana detaljnije od preostalih triju, pa i smještena više u hijerarhiji poglavlja.

U nastavku, uz kritički osvrt, mnogo detaljnije opisujemo njezine postavke i predviđanja, a navodimo i neka ranije provedena istraživanja. 


\section{KONSTRUALNA HIPOTEZA KAO ISHODIŠNI MODEL}

\subsection{Postavke i predviđanja konstrualne hipoteze}

Konstrualna hipoteza (izv. eng. construal hypothesis; Frazier i Clifton, 1996) polazi od pretpostavke da su strukturno-značenjska obilježja odnosnih rečenica odlučujući čimbenik u sintaktičkoj obradi. Drugim riječima, preferencije vezivanja ovise ponajviše o strukturnoznačenjskim osobitostima i odnosima imenica unutar imenske skupine (NP) koja prethodi odnosnoj surečenici. U skladu s time, preferencije vezivanja variraju i među jezicima i unutar pojedinoga jezika, budući da su i načini izražavanja odnosa u imenskim skupinama različiti.

Hipoteza je nastala prvenstveno kao odgovor na sve učestalije nesustavnosti u rezultatima istraživanja među jezicima, pa i unutar jezika. ${ }^{17}$ Njezini tvorci odbacuju činjenicu da je obrada vođena univerzalnim zakonima i načelima poput kasnoga zatvaranja (Frazier i Clifton, 1997). Smatraju da se govornici u obradi vode svim dostupnim razinama obavijesti (strukturnima i značenjskima) koje se postupno nadograđuju u postojeću domenu obrade (izv. eng. processing domain; Frazier i Clifton, 1996: 31-32). Frazier i Clifton na ovaj su način nastavili promišljanja koja su godinu dana ranije započeli Gilboy i sur. (1995) analizirajući značenjske odnose između imenica unutar imenskih skupina u sličnim studijama.

Prema konstrualnoj hipotezi odlučujuću ulogu u preferencijama vezivanja tako imaju odnosi imenica unutar imenske skupine koje mogu biti dijelom iste ili različite domene obrade (vidi Gilboy i sur., 1995; Frazier i Clifton, 1996; 1997), a važnu će ulogu imati i način na koji je unutar imenske skupine označena, tj. uvedena druga imenica (njezin referencijalni status; vidi Frazier i Clifton, 1996; 1997).

U skladu s navedenim, izdvajaju se dva glavna predviđanja konstrualne hipoteze:

1) Ako su imenice unutar složene NP dijelom iste domene obrade (genitivne dopune), preferencije će varirati među jezicima i unutar jezika. Naime, ovisit će o vrstama tih dopuna i načinima izražavanja odnosa, što se u različitim jezicima različito obilježava.

2) Ako imenice unutar složene NP nisu dijelom iste domene obrade (izrazi za označavanje komitativnosti/socijativnosti i lokacije), predviđa se preferencija prema drugoj imenici. Kako

\footnotetext{
${ }^{17}$ Kako je ranije spomenuto, jedno je istraživanje preferencija vezivanja u francuskome pokazalo da u tome jeziku postoji preferencija vezivanja na prvu imenicu unutar imenske skupine (Zagar i sur., 1997), dok je drugim istraživanjem $u$ istome jeziku utvrđena preferencija vezivanja na drugu imenicu (Baccino i sur., 2000). Nesustavnosti su pronađene i u istraživanjima u talijanskome jeziku (De Vincenzi i Job, 1993, ali cf. FrenckMestre i Pynte, 2000).
} 
su imenice tada povezane prijedlogom koji ima mogućnost tematskog označavanja (izv. eng. thematically licencing preposition), doći će do prebacivanja fokusa na drugu imenicu (Frazier i Clifton, 1996: 73).

Slika 2 u nastavku prikazuje preferencije vezivanja s obzirom na različite odnose imenica unutar imenske skupine, tj. s obzirom na prijedlog bez i s mogućnošću tematskog označavanja.

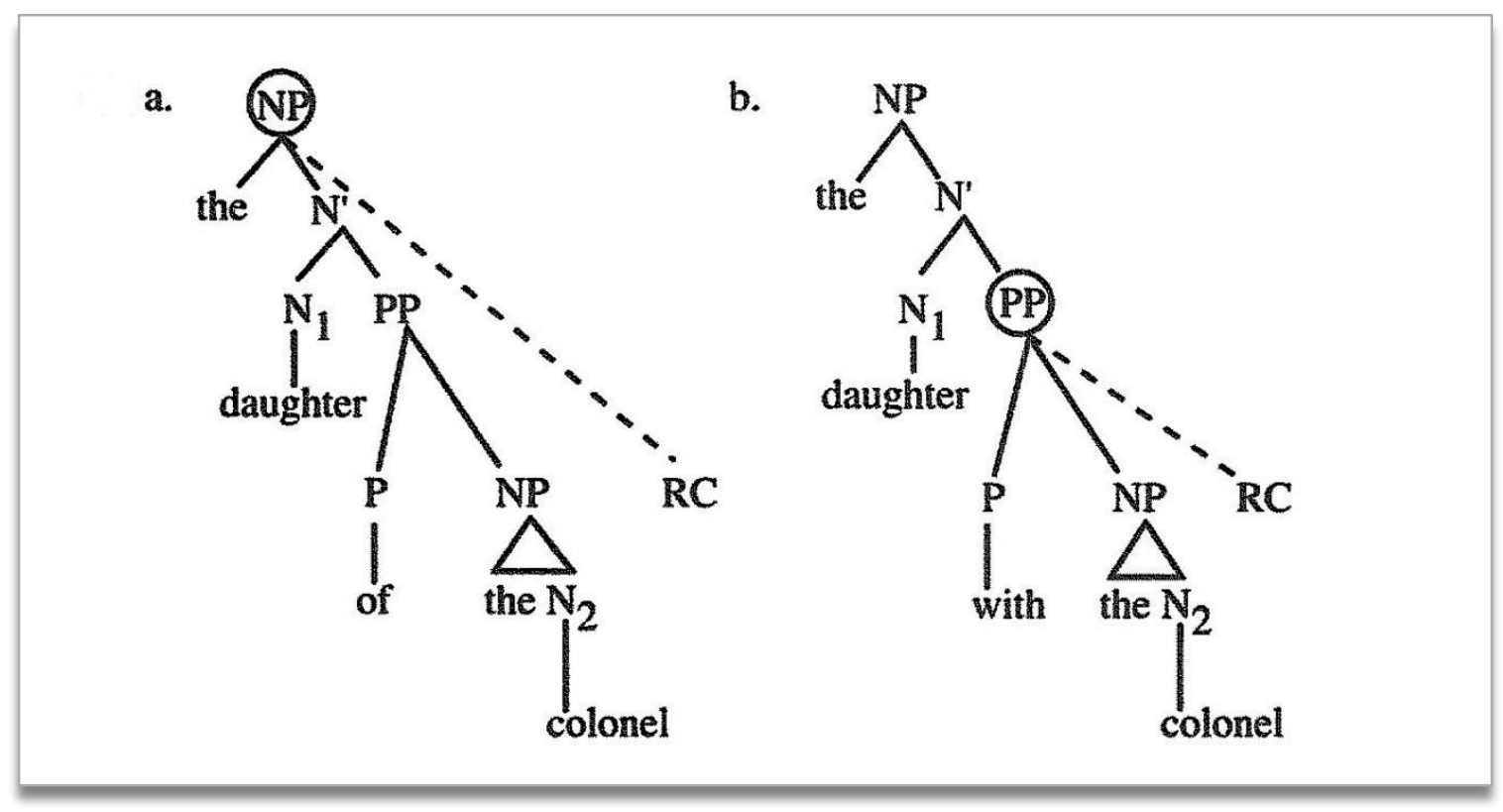

Slika 2. Preferencije vezivanja s obzirom na različite odnose imenica u NP (a. i b.); preuzeto od Frazier i Clifton (1997: 281).

Gilboy i sur. (1995) razmatrali su različite mogućnosti izražavanja odnosa imenica u imenskim skupinama te ih doveli u vezu s odgovorima sudionika istraživanja. U njihovom su ispitivanju preferencija vezivanja u različitim vrstama odnosnih rečenica sudionici bili govornici strukturno različitih jezika, engleskoga i španjolskoga. Istraživanjem su dokazali velik utjecaj značenjskih odnosa antecedenata na tumačenje dvosmislenih odnosnih rečenica u obje skupine sudionika, pri čemu su govornici španjolskoga u nešto većoj mjeri bili osjetljivi na te odnose, od govornika engleskoga. Elizabeth Gilboy i suradnici odnose su imenica unutar NP podijelili u nekoliko podskupina, upravo ovisno o njihovim značenjskim obilježjima. Tablica 2 prikazuje primjere ispitnih podražaja i preferencije vezivanja s obzirom na podskupinu kojoj pripadaju pojedine strukture, a preuzete su iz originalnoga rada (Gilboy i sur., 1995: 145). Podskupine su grupirane s obzirom na značenjske odnose, a posljednji stupac u tablici prikazuje postotak preferencija prema drugoj imenici unutar NP govornika engleskoga i španjolskoga jezika. 
Tablica 2. Primjer ispitnih podražaja iz istraživanja Gilboy i sur. (1995).

\begin{tabular}{|c|c|c|c|}
\hline Skupina & Podskupina & Primjer (eng.) & $\begin{array}{l}\text { \% preferencije prema } \\
\text { drugoj imenici }\end{array}$ \\
\hline \multirow{4}{*}{ A } & \multirow{2}{*}{ gradbenost } & \multirow{2}{*}{ a sweater of wool } & eng: $20 \%$ \\
\hline & & & španj: $7 \%$ \\
\hline & \multirow{2}{*}{ količina } & \multirow{2}{*}{ a cup of sugar } & eng: $43 \%$ \\
\hline & & & španj: $17 \%$ \\
\hline \multirow{6}{*}{$\mathrm{B}$} & \multirow{2}{*}{ rodbinski odnosi } & \multirow{2}{*}{ the daughter of the colonel } & eng: $63 \%$ \\
\hline & & & španj: $47 \%$ \\
\hline & \multirow{2}{*}{ poslovni odnosi } & \multirow{2}{*}{ the assistant of the lawyer } & eng: $35 \%$ \\
\hline & & & španj: $33 \%$ \\
\hline & \multirow{2}{*}{ neotuđiva posvojnost } & \multirow{2}{*}{ the window of the plane } & eng: $62 \%$ \\
\hline & & & španj: $54 \%$ \\
\hline \multirow{2}{*}{$\mathrm{B}^{\prime}$} & \multirow{2}{*}{ otuđiva posvojnost } & \multirow{2}{*}{ the book of the student } & eng: $53 \%$ \\
\hline & & & španj: $64 \%$ \\
\hline \multirow{2}{*}{$\mathrm{C}$} & \multirow{2}{*}{ socijativnost, lokacija } & \multirow{2}{*}{ the sauce with the steak } & eng: $69 \%$ \\
\hline & & & španj: $83 \%$ \\
\hline
\end{tabular}

Brojčani podatci iz Tablice 2 jasno pokazuju da u španjolskome prevladavaju preferencije vezivanja na prvu imenicu, što je suprotno preferencijama u engleskome jeziku. Nadalje, primjeri iz skupina B, B' i C, za razliku od onih iz skupine A, primjeri su u kojima je određeni član (the u engleskome) referencijalno sredstvo, tj. on dodatno obilježava i označava drugu imenicu, što također može utjecati na tumačenje rečenice. ${ }^{18}$ Naposljetku, podatci pokazuju znatno veće preferencije prema drugoj imenici u obama jezicima ako su imenice povezane prijedlogom s mogućnošću tematskog označavanja (eng. with; španj. con). U primjeru iz skupine B' odnose dodatno usložnjavaju različita obilježja živosti. Jasno je da će konačno tumačenje takvih rečenica ponajviše ovisiti o onome što sadržajno slijedi u zavisnoj rečenici, to jest veže li se odnosna surečenica zbog svojega sadržaja na imenicu s obilježjem živo ili na onu s obilježjem neživo. U ovom primjeru postaje jasno da će način na koji tumačimo rečenicu ovisiti o njezinomu cjelokupnom sadržaju, a ne isključivo o izdvojenim strukturnim osobitostima.

Konstrualna se hipoteza donekle nastavlja na interaktivne modele (Altmann i Steedman, 1988; MacDonald i sur., 1994) jer također zagovara ideju o mogućnosti istovremene obrade strukturne

\footnotetext{
${ }^{18}$ Referencijalnost se u hrvatskome iskazuje atribucijom (preciziranjem sadržaja pojma leksičkim sredstvima,
} najčešće pridjevom) ili determinacijom (zamjenicama i neodređenom riječju jedan) (vidi Kordić, 1995). 
i značenjske razine, tj. činjenicu da su govornicima prilikom obrade istovremeno dostupne sve razine obavijesti. Ipak, od tih se modela i razlikuje utoliko što pruža donekle jasnija predviđanja obrade određenih struktura (odnosnih rečenica) s obzirom na to pripadaju li antecedenti istoj ili različitoj domeni obrade (Frazier i Clifton, 1996). Druga razlika leži u predviđanjima obrade odnosnih rečenica s višestrukim mogućnostima interpretacije. Naime, interaktivni modeli predviđaju kompeticiju i produljeno vrijeme čitanja, dok konstrualna hipoteza nema takvih predviđanja. Od istraživanja Elizabeth Gilboy i njezinih suradnika 1995. i konačnoga oblikovanja konstrualne hipoteze sljedeće godine (Frazier i Clifton, 1996), u većoj se mjeri započelo s analiziranjem značenjskih obilježja rečenica i promatranjem njihovog utjecaja na sintaktičku obradu i preferencije vezivanja. 


\subsection{Istraživanja u okviru konstrualne hipoteze}

Predviđanja konstrualne hipoteze u nekim su istraživanjima potvrđena (primjerice, Papadopoulou, 2006), a u nekim drugima pak opovrgnuta (primjerice, Mendelsohn i Pearlmutter, 1999; više u Papadopoulou, 2006; Hemforth i sur., 2015). Oprečnost spoznaja nužno ne iznenađuje, ali upućuje na važnost i potrebu za novim istraživanjima (Hemforth i sur., 2000a).

U skladu s prvim predviđanjem, u nekim je jezicima pronađena jasna preferencija prema prvoj ili drugoj imenici, a različite se spoznaje objašnjavaju razlikama u strukturnim obilježjima jezika te značenjskim obilježjima ispitanih rečenica. U određenom broju istraživanja jasne preferencije pak uopće nisu nađene. Drugim riječima, odgovori sudionika na upitniku kojim se ispitivalo njihovo tumačenje dvosmislenih odnosnih rečenica pokazali su podjednake preferencije prema objema imenicama ili se vrijeme čitanja u uvjetima vezivanja na prvu ili na drugu imenicu nije značajno razlikovalo (primjerice, Frazier i Clifton, 1996; Traxler i sur., 1998). Nedostatak jasnih preferencija u okviru konstrualne hipoteze objašnjava se činjenicom da u takvim strukturama obje imenice koje prethode odnosnoj zamjenici pripadaju istoj domeni obrade, zbog čega imaju jednaku mogućnost biti antecedentom ako značenjski odgovaraju onome što slijedi u odnosnoj surečenici (Frazier i Clifton, 1996; Papadopoulou, 2006).

$\mathrm{S}$ druge strane, jasne preferencije prema prvoj ili drugoj imenici pripisuju se razlikama $\mathrm{u}$ načinima izražavanja odnosa u složenoj NP, kao i različitim vrstama tih odnosa (Gilboy i sur., 1995; Frazier i Clifton, 1996; 1997; Traxler i sur., 1998; Papadopoulou, 2006). Primjerice, preferencija prema drugoj imenici u NP koju čini genitivna dopuna u engleskome može se objasniti činjenicom da se u tome jeziku posvojnost izražava dvama oblicima, normanskim ili saksonskim genitivom (primjer u nastavku preuzet je iz Traxler i sur., 1998):

(7a) The son of the driver that had the moustache .... (normanski oblik)

(7b) Driver's son that had the moustache ... (saksonski oblik)

[ hrv. Sin vozača / vozačev sin koji je imao brkove ... ].

Budući da u potonjem primjeru (7b) ne dolazi do dvosmislenosti (jasno je da sin ima brkove, a ne vozač), taj se oblik u studijama preferencija vezivanja izbjegava. Posljedica uporabe prvoga oblika (7a) jest, kako autori navode, prebacivanje pažnje i fokusa upravo na drugu imenicu (u ovome primjeru, na vozača) za govornike engleskoga jezika. Naime, da se odnosna surečenica 
odnosi na sina, vjerojatnije je da bi bio upotrijebljen saksonski genitiv. S druge strane, u španjolskome je jeziku izražavanje posvojnosti moguće jedino uporabom oblika koji bi odgovarao normanskom genitivu u engleskome jeziku (eng. of; španj. de), stoga u tome jeziku postoji preferencija prema prvoj imenici. Takvo je objašnjenje razlika u preferencijama među jezicima itekako zanimljivo, ali i danas upitno (Carreiras i Clifton, 1999; Hemforth i sur., 2000a; Papadopoulou, 2006; Hemforth i sur., 2015). Naime, iako alternativne mogućnosti izražavanja posvojnosti postoje u još nekim jezicima (primjerice, nizozemskom ili hrvatskom), u njima je ipak pronađena preferencija vezivanja na prvu imenicu (Brysbaert i Mitchell, 1996; Lovrić, 2003). Traxler i sur. (1998) i Papadopoulou (2006) u svojim radovima vrlo jasno upozoravaju na manjkavosti i neodređenosti prve postavke konstrualne hipoteze, zbog čega apeliraju na nužnost provedbe novih istraživanja kako bi se rasvijetlili čimbenici u pozadini razlika u rezultatima.

Drugo je predviđanje konstrualne hipoteze, za razliku od prvoga, naizgled jednoznačno. Ako su imenice unutar imenske skupine povezane prijedlogom koji ima mogućnost tematskog označavanja čime uzrokuje prebacivanje fokusa na drugu imenicu, tada će u svim jezicima postojati preferencija upravo prema njoj (Frazier i Clifton, 1996: 73). Unatoč jednostavnosti pretpostavke rezultati istraživanja ponovno su oprečni.

Gilboy i sur. (1995) prvi su ustanovili da prijedlog s mogućnošću tematskog označavanja može biti odlučujućim čimbenikom u obradi, tj. da može utjecati na tumačenje odnosnih rečenica. Dapače, svojim su spoznajama potaknuli oblikovanje hipoteze. Do sličnih su rezultata u istraživanju u talijanskome jeziku došli i De Vincenzi i Job (1993). Sofisticiranim su mjerama pokreta očiju spoznaje o utjecaju prijedloga na sintaktičku obradu u engleskome jeziku potvrdili Traxler i sur. (1998), a u francuskome i talijanskome Frenck-Mestre i Pynte (2000). Papadopoulou (2006) je također ispitala valjanost ove pretpostavke u grčkome jeziku. Metodom upitnika i mjerama u stvarnom vremenu dokazala je preferenciju vezivanja na drugu imenicu u uvjetu u kojem su imenice bile povezane prijedlogom kojim se označava socijativnost (prijedlog $s$; grč. me). U skladu s predviđanjima, u uvjetu u kojem su imenice bile u genitivnoj dopuni potvrdila je preferencije prema prvoj imenici. Mendelsohn i Pearlmutter (1999) u jednom su eksperimentu usporedili način obrade rečenica s različitim vrstama genitivnih dopuna (gradbenost i količina naspram poslovnih i rodbinskih odnosa posvojnosti), a u drugome rečenice s dvjema vrstama prijedložnih dopuna (socijativnost naspram lokacije). Kako bi ispitali ranije i kasnije faze obrade, u istraživanju su upotrijebili i metodu upitnika i mjerenja u stvarnom vremenu. U tri su uvjeta: (1) izražavanje gradbenosti/količine i 2) 
posvojnosti prijedlogom of (øod) te 3) lokacije prijedlogom near (blizu) pronašli češće preferencije prema prvoj imenici. Jedini uvjet u kojemu je pronađena značajna preferencija vezivanja na drugu imenicu bio je onaj u kojem se prijedlogom with $(s)$ označavala socijativnost ili kakvo opisno obilježje. Njihove spoznaje nisu u potpunosti u skladu s predviđanjima konstrualne hipoteze prema kojoj bi i prijedlozi kojima se označava lokacija trebali utjecati na promjenu preferencije. Autori pozivaju na provedbu većeg broja sličnih istraživanja (s raznolikim, ali ujedno i kontroliranim ispitnim podražajima), koja će doprinijeti razumijevanju načina na koji različiti značenjski odnosi utječu na sintaktičku obradu.

Thornton i sur. (1998) su preferencije vezivanja govornika engleskoga ispitali zadatkom dovršavanja rečenica. Odnosnim su surečenicama prethodile imenske skupine kojima su se izražavale posvojnost ili lokacija. Predviđanja hipoteze nalažu da bi u prvom uvjetu trebala postojati ili jasna preferencija prema jednoj od imenica ili ujednačene preferencije prema objema imenicama, zbog činjenice da one pripadaju istoj domeni obrade. U drugome bi uvjetu trebala postojati preferencija prema drugoj imenici. Potpuno suprotno predviđanjima hipoteze, ukupne su preferencije prema drugoj imenici, neovisno o prijedlogu unutar imenske skupine, iznosile visokih 70\%. Dapače, veća je preferencija prema drugoj imenici pronađena u rečenicama s genitivnim dopunama nego u rečenicama u kojima se prijedlogom označavala lokacija. Efekt prijedloga ipak nije bio značajan, kao ni interakcije.

Felser, Marinis i Clahsen (2003) otišli su korak dalje i ispitali razlikuju li se odrasli govornici njemačkoga i djeca u načinu na koji obrađuju odnosne rečenice. U eksperimentu su varirali vrstu imenske skupine koja prethodi odnosnoj zamjenici kako bi provjerili jesu li preferencije odraslih sudionika i djece različite s obzirom na navedena obilježja rečenica. Rezultatima su potvrdili predviđanja konstrualne hipoteze samo kod odraslih sudionika. Drugim riječima, samo su se odrasli u određivanju preferencija vodili značenjskim obilježjima struktura. U skupini djece preferencija je u većoj mjeri ovisila o opsegu radnoga pamćenja nego o strukturno-značenjskim obilježjima rečenica.

Hemforth i sur. (2000a) spoznaje o mogućem utjecaju prijedloga na sintaktičku obradu pripisuju ponajviše dostupnošću i prominentnošću referenata u diskursnoj jedinici. Prema autorima je moguće da prijedlozi unutar imenske skupine umanjuju dostupnost prve imenice u referentnom izrazu (primjerice, djevojčica s haljinom, ormar blizu stola ili knjiga na klupi) zbog čega je vjerojatnije da će se, prilikom obrade surečenice koja slijedi, fokus prebaciti na drugu imenicu. Pritom ne isključuju mogućnost da, neovisno o prijedlogu, čitava imenska skupina čini jedan referentni izraz. Autori pozivaju na nove eksperimentalne studije kojima bi 
se ove mogućnosti dodatno ispitale (Hemforth i sur., 2000a: 170). Tek se djelomice naslućuje da u tumačenju odnosnih struktura sa složenim NP važnu ulogu može imati i obavijesni ustroj jezika.

Konstrualna se hipoteza temelji na očitom postojanju različitih mogućnosti tumačenja rečenica s obzirom na njihova strukturna i značenjska obilježja. U skladu s time, a u okviru suvremenih spoznaja o jezičnoj obradi, jedinstveni su se zakoni i načela sintaktičke obrade utemeljeni isključivo na strukturnim obilježjima ponovno pokazali neopravdanima ili, u najmanju ruku, nepotpunima. Ipak, hipoteza ni danas ne pruža u potpunosti jasan uvid u složene strukturnoznačenjske odnose u različitim jezicima. Sami autori navode da su razlike među jezicima neizbježne, ali da upravo u njima leži objašnjenje za kojim se u teorijama jezične obrade traga te da ih tek predstoji istražiti (Frazier i Clifton, 1997). U nastavku iznosimo neke uočene nedostatke hipoteze i nudimo mogućnost kako istima pristupiti kako bi se model unaprijedio. 


\subsection{Kritički osvrt i nedostatci konstrualne hipoteze}

Konstrualna hipoteza zbog svojega je usmjerenja na strukturno-značenjska obilježja u pristupanju sintaktičkoj obradi ishodištem ovoga doktorskog istraživanja. Ipak, ni ona ne pruža u potpunosti jasne i konačne odgovore o tom fenomenu i mehanizmima kojima je obrada vođena, a čini se da su toga svjesni i sami autori. U njihovim se radovima mogu pronaći izjave poput: „Mislimo da raznolika značenjska i pragmatička obilježja utječu na konačni odabir govornika (...)“ (Frazier i Clifton, 1997: 282) te: „Nipošto nismo odgovorili na pitanja o tome kako se dolazi do konačne interpretacije; tek smo postavili nova“ (ibid.: 290). U istome teorijskom radu autori zaključuju:

Jezici se razlikuju u mnogim obilježjima o čijoj se važnosti zbog utjecaja na interpretaciju odnosnih rečenica počelo navelike raspravljati. Ona uključuju osobitosti odnosnih zamjenica, načine izražavanja obavijesti $i$ značenjskih odnosa, načine razrješavanja dvosmislenosti, (...). Te međusobno neovisne, ali neizbježne razlike među jezicima mogle bi konačno objasniti uzroke razlika u preferencijama govornika jezika. (ibid.: 290). ${ }^{19}$

Neki su od glavnih nedostataka hipoteze nesustavno uvođenje pojmovlja te nedostatno i neodređeno objašnjavanje pojavnosti u općem i specifičnom kontekstu. Primjerice, u pokušaju objašnjavanja razlika u preferencijama prilikom tumačenja naizgled jednakih struktura $u$ različitim jezicima, autori sporadično uvode izraze poput domena obrade (izv. eng. processing domain), promjena fokusa (izv. eng. focus shift), dostupnost i istaknutost referenata (izv. eng. salience and prominence of discourse referents) ili pak naslućuju utjecaj pragmatičkih čimbenika na obradu (izv. eng. influence of pragmatic factors).

Postupnim uvođenjem navedenih pojmova i tvrdnji koji se mogu dovesti u vezu sa spregom strukturne, značenjske (pa i obavijesne) razine, autori počinju uviđati da su govornici tijekom obrade vođeni svim tim čimbenicima koji su se prethodno neutemeljeno zanemarivali (vidi i Hemforth i sur., 2000a; 2015). Ipak, isti se nedovoljno problematiziraju, posebice u kontekstu dobivenih rezultata ili - što je još važnije - u kontekstu strukture istraženoga jezika. U nastavku će se pružiti jasnija određenja tih pojmova kako bi se oni u većoj mjeri nego je to dosad bio slučaj doveli u vezu s jezičnom obradom.

\footnotetext{
${ }^{19}$ Citate je prevela i istaknula AM.
} 
Prema Krifka i Musan (2012) jezici se razlikuju u načinima izražavanja obavijesti, uvođenja i redanja bitnih obavijesti, označavanja referenata te nečega poznatoga i nepoznatoga, tj. novoga $\mathrm{u}$ iskazu. $\mathrm{U}$ tome se smislu fokus ${ }^{20}$ kao način izražavanja obavijesti ne razlikuje od ostalih univerzalnih jezičnih kategorija poput živosti, roda i broja. Naime, svi prirodni jezici posjeduju načine izražavanja ove kategorije, neki izborom riječi, neki promjenom njihova redoslijeda, a neki prozodijskim sredstvima (Erteschik-Shir, 2009).

U lingvističkoj su se povijesti terminološka određenja fokusa mijenjala, ali bez obzira na lingvističku školu i teorijsko usmjerenje, on najčešće označava pojavu nečega novog, neočekivanog, posebno istaknutog ili suprotnog u iskazu (Krifka i Musan, 2012: 5-6), a uporaba mu je određena značenjem čitavoga iskaza i pragmatičkim čimbenicima. Lambrecht (1994) smatra da se fokus može odnositi na jedan ili na više konstituenata u iskazu, odnosno da se oni razlikuju u svome dometu, stoga razlikuje fokus širokoga i uskoga dometa (izv. eng. wide and narrow scope; vidi i Van Valin, 2001). Štogod da čini fokus u pojedinom iskazu, on govorniku mora predstavljati smislenu jedinicu.

Uporaba je pojma fokus u psiholingvističkim modelima terminološki posebno zbunjujuća. Wind Cowles (2012: 287) ističe da u tim istraživanjima pojam fokus u pravilu označava predmet pozornosti govornika (izv. eng. focus of attention), odnosno usmjeravanje njegove/njezine pažnje na najistaknutiji referent u rečenici. Takvo se određenje može povezati s njegovim određenjem u okviru konstrualne hipoteze, što nije istovjetno uporabi toga pojma u općoj teorijskoj lingvistici. Neujednačeno nazivlje može biti uzrokom nedovoljno preciznih spoznaja o prirodi utjecaja fokusa i načina na koji je on u jeziku izražen, na obradu rečenice i diskursa. Iako izražavanje obavijesti nesumnjivo igra važnu ulogu u procesu jezične obrade pa i u razrješavanju dvosmislenosti - još uvijek nije posve jasno na koji se način to odvija (Wind Cowles, 2012: 287).

U ovome će se istraživanju pojam fokus također prvenstveno odnositi na pažnju govornika, iz jednostavnoga razloga što je takvo određenje ugrađeno u ishodišnu konstrualnu hipotezu. Unatoč tomu, zbog uočenih nesustavnosti u prijašnjim radovima, u ovoj će se disertaciji jasnije odijeliti i istaknuti i važnost obavijesnoga u tumačenju iskaza, a u tome će se smjeru odvijati i rasprava.

\footnotetext{
${ }^{20}$ Iako u ovu kategoriju spada i termin topik, detaljna razgraničenja tih pojmova nisu od presudne važnosti u ovom doktorskom istraživanju koje ne polazi iz obavijesne strukture. Cilj je samo navesti nedostatke psiholingvističkih modela i uputiti na potrebu za pomnijim i detaljnijim razmatranjem kompleksnih pojavnosti.
} 
Prema Wind Cowles (2012: 293) obavijesni je ustroj most između mentalnih stanja govornika i jezične forme te kao takav predstavlja sredstvo za označavanje mentalnih stanja govornika u odnosu na obavijest koja se iskazom želi prenijeti. Stoga će oslanjanje na pravila izražavanja obavijesti koja vrijede u pojedinome jeziku govorniku pomoći u obradi i tumačenju rečenica. Jedno je od pitanja u psiholingvistici kako se i kada govornik oslanja na ta i neka druga pravila, tj. u kojoj mjeri strukturna i obavijesna pravila utječu na integrativne procese u obradi te mogu li ona utjecati i na razrješavanje dvosmislenosti iskaza (Frazier i Clifton, 1998).

Konstrualna hipoteza naglašava međuovisnost strukture i značenja u sintaktičkoj obradi, a toj se vezi donekle pridružuje i obavijest. Ovaj se složeni odnos temelji na važnosti trenutne domene obrade i fokusa govornika, tj. na povezanosti između položaja antecedenata u odnosnoj rečenici, njihovoga značenjskog odnosa i načina na koji oni zajedno utječu na usmjeravanje pažnje govornika jezika. Iako nešto važno i novo u iskazu često zauzima inicijalni položaj kako bi se posebno istaknulo i tako postalo dostupnije (Erteschik-Shir, 2009: 75-76; Reich, 2012: 415-416), postavlja se pitanje je li doista samo položaj taj koji će utjecati na promjenu pažnje i preferencije pojedinca, odnosno koji su još jezično-specifični mehanizmi u pozadini (Reich, 2012).

Fokus (u svome temeljnom općelingvističkom teorijskom određenju) itekako ima ulogu u razumijevanju struktura u različitim jezicima, bez obzira je li posebno istaknut položajem, označen prozodijskim i/ili sintaktičkim sredstvima ili pak određen kontekstom (Schafer i sur., 2000; Wind Cowles, 2012). Sve se češće, posebice u funkcionalnim pristupima proučavanju jezičnih pojavnosti, govori o međudjelovanju strukture, značenja, prozodije i obavijesti (primjerice, Reich, 2012; Wind Cowles, 2012; Raffaelli, 2015), što je dokazom kompleksnosti mehanizama sintaktičke obrade. Vratimo li se na ranije spomenuti problem preobilja lingvističkih i psiholingvističkih teorija i modela obrade, postaje jasnije zašto je tome tako: ista se pojavnost često promatra isključivo iz jednoga polazišta, a šira se slika zanemaruje.

Raffaelli (2015) ističe važnost sveubuhvatnih funkcionalnih pristupa proučavanju lingvističkih pojavnosti navodeći da se gramatičke strukture mogu objasniti jedino u sprezi sa semantikom i pragmatikom: „Suvremeni funkcionalni pristupi sintaksi smatraju da su semantika i pragmatika neraskidive od sintakse kako bi se cjelovito proniknulo u načela ustroja rečenice te općenito $\mathrm{u}$ načela funkcioniranja jezika“ (ibid.: 250).

Načela funkcioniranja jezika iz navoda mogu se u kontekstu psiholingvističkih istraživanja shvatiti i kao način na koji govornici obrađuju, tj. razumijevaju određene strukture. Na ovome mjestu stoga valja istaknuti upravo ulogu psiholingvistike u tom složenom procesu. Dobro 
planiranim, detaljno promišljenim i ispravno provedenim eksperimentima moguće je steći uvid u kognitivne procese govornika i iste dovesti u vezu s jezičnim strukturama koje se ispituju, a što je donekle otežano upravo teorijskim preobiljem (Poulsen, 2005). Ispravnim se načinom čini provedba nepristranih i pomno promišljenih eksploratornih istraživanja u jezicima te njihovo dovođenje u vezu s općelingivstičkim i jezično-specifičnim kontekstom (ErteschikShir, 2009; Hemforth i sur., 2015).

Ova je disertacija utemeljena na psiholingvističkim modelima obrade i ne proizlazi iz strogo teorijskih lingvističkih pristupa. Ipak, istraživanjem se obrade itekako može doprinijeti razumijevanju općih teorijskih postavki. Osim toga, već je na nekoliko mjesta spomenuto da je raspravu o određenim pojavnostima nemoguće voditi bez dovođenja u vezu strukturnoznačenjskih i obavijesnih načela, s preferencijama izvornih govornika.

S obzirom na sve navedeno, zaključujemo da bi se konstrualna hipoteza, ali i općenito modeli sintaktičke obrade, mogla unaprijediti uvođenjem sustavnijega nazivlja, provedbom kontroliranijih eksperimenata uporabom višestruke metodologije uz sumiranje i uzimanje u obzir rezultata ranije provedenih istraživanja (neovisno o ishodišnom modelu), donošenjem opreznijih zaključaka, a ponajviše uvažavanjem zakonitosti jezika koji se istražuje.

Budući da upravo osobitosti pojedinoga jezika i njegovih struktura mogu pružiti dodatan uvid u složene mehanizme sintaktičke obrade i tako doprinijeti širenju spoznaja, u nastavku iznosimo neke osobitosti hrvatskoga jezika. Prikazat će se opća obilježja hrvatske sintakse (gramatički i obavijesni ustroj), obilježja odnosnih rečenica (odnos glavne i zavisne rečenice i vrsta veznih riječi) te obilježja genitivnih dopuna i prijedložno-padežnih izraza, budući da su upravo one relevantne za proučavanje sintaktičke obrade i preferencija vezivanja u okviru konstrualne hipoteze. 


\section{OBILJEŽJA HRVATSKE SINTAKSE}

\subsection{O gramatičkome i obavijesnome ustroju hrvatskoga}

Rečenica je temelj ljudske komunikacije, a njezin gramatički ustroj i načela kombiniranja značenjskih jedinica s ciljem prenošenja smislene poruke predmet su proučavanja sintakse kao lingvističke discipline (Raffaelli, 2015: 245, 246).

Relevantne hrvatske gramatike i druga normativna literatura u raspravama o sintaksi najčešće izdvajaju gramatički od obavijesnoga ustroja, odnosno promatraju rečenicu kao gramatičku i kao obavijesnu jedinicu. Prvo u pravilu predstavlja redoslijed subjekta, predikata i drugih članova rečenice kao gramatičke jedinice, a drugo njihovo redanje i odnose s obzirom na komunikacijsku obavijest (Silić i Pranjković, 2005). Takav je prikaz donekle pojednostavljen jer su terminološka određenja sintaktičkih odnosa na više razina nesustavna i neujednačena (za raspravu vidi Peti-Stantić, 2007). Ipak, bez obzira na pojmovlje koje je u uporabi i bez obzira na polazišni teorijski okvir, općeprihvaćeno je da se riječi kojima se izriču sintaktičke kategorije u hrvatskome jeziku redaju relativno slobodno. Mjesto se riječima može mijenjati, a da se pritom nužno ne promijeni njihov međusobni odnos (Barić i sur., 2005; Silić i Pranjković, 2005). Budući da je hrvatski flektivni jezik, promjena redoslijeda riječi neće nositi gramatičku obavijest kao što je slučaj u engleskome. Ulogu mijenjanja gramatičkih odnosa nose padeži, a promjena redoslijeda riječi uglavnom predstavlja kakve stilske tančine (Katičić, 2002). Usporkos relativno slobodnom redoslijedu riječi, način njihova kombiniranja itekako oslikava značenjske odnose i može utjecati na tumačenje iskaza (Van Valin, 2001: 1; Raffaelli, 2015: 249).

Obavijesni je ustroj u uskoj vezi s izvanjezičnim kontekstom koji nesumnjivo utječe na tumačenje iskaza, posebice ako je on dvosmislen. Govornici su hrvatskoga u interpretaciji iskaza vođeni promjenom uobičajenoga redoslijeda riječi (uvrštavanjem ili izostavljanjem), posebnom uzlaznom ili silaznom intonacijom u govorenome jeziku vođenom implicitno usvojenim pravilima ritmomelodijskih zakonitosti, osobitostima u pisanome jeziku i dr. (vidi i Katičić, 2002; Silić i Pranjković, 2005; Peti-Stantić, 2007). Ipak, inicijalne preferencije govornika hrvatskoga i pravila oslanjanja na strukturne i značenjske čimbenike u nedostatku konteksta nisu potpuno jasne. Konstrualna se hipoteza dotiče upravo toga pitanja. Utemeljena je naime na međusobnom djelovanju tih čimbenika i ne isključuje mogućnost da je sintaktička obrada vođena različitim mogućnostima izražavanja obavijesti, kao i različitim mogućnostima izražavanja odnosa antecedenata koji prethode odnosnoj surečenici. 
Kako bi slika bila potpuna, u nastavku prikazujemo obilježja odnosnih rečenica i načine izražavanja odnosa u genitivnim dopunama i prijedložno-padežnim izrazima u hrvatskome.

\subsection{Odnosne rečenice u hrvatskome}

Odnosna ili relativna rečenica zavisna je struktura koja se pridružuje imenicama, imenskim skupinama, zamjenicama, prilozima i prijedložnim izrazima u glavnoj rečenici i svojim sadržajem proširuje njihov sadržaj (Barić i sur., 2005). U odnosnim se strukturama zavisna surečenica u glavnu uvodi po antecedentu koji može biti imenica, imenska riječ ili šira imenska skupina (Katičić, 2002). Od ostalih se zavisnosloženih rečenica razlikuje po tome što vezna sredstva istovremeno i povezuju dvije surečenice, i zastupaju jednu ili više sastavnica iz glavne surečenice (Silić i Pranjković, 2005). Iako se na temelju navedenih obilježja relacije, odredbe i zamjene može nametnuti osnovna atributna funkcija (Kordić, 1995), odnosne rečenice nisu nužno atributne (više u Barić i sur., 2005; Silić i Pranjković, 2005).

Taj tip strukture pripada najstarijoj vrsti zavisnih rečenica u indoeuropskim jezicima (Kurzová, 1981), ali je vrlo kompleksna, i na pojmovnoj i na jezičnoj razini. U prilog njezinoj složenosti govore i rezultati sve većeg broja razvojnih psiholingvističkih studija, kao i studija usporedbe populacije uredna i narušena jezična statusa (Håkansson i Hansson, 2000; Friedmann i Novogrodsky, 2004; Balija, Hržica i Kuvač Kraljević, 2012; Balija Mećar, Pavičić Dokoza i Dulčić, 2016; Matić i Kuvač Kraljević, 2017). Unatoč složenosti ta je struktura razmjerno česta u hrvatskome jeziku, kako u govorenom, tako i u pisanom diskursu. ${ }^{21}$ Složenost je odnosne rečenice s jedne strane razlogom njezina nedostatnoga i manjkavoga opisa (čak i u gramatikama hrvatskoga jezika), ali ju s druge strane čini istraživački iznimno zanimljivom (primjerice, u razvojnim studijama ili studijama sintaktičke obrade kakvima pripadaju i studije preferencija vezivanja i tumačenja odnosnih rečenica u različitim jezicima).

Prema najčešćim klasifikacijama odnosnih rečenica $u$ gramatikama hrvatskoga jezika i opsežnim monografijama (Kordić, 1995; Barić i sur., 2005; Silić i Pranjković, 2005) moguće je izdvojiti nekoliko njezinih temeljnih obilježja:

1) zavisna je rečenica;

\footnotetext{
${ }^{21}$ Razlozi su, između ostaloga, nekorištenje struktura koje su u nekim drugim jezicima funkcionalni ekvivalenti odnosnim rečenicama (Maček, 1970; Kordić, 1995).
} 
2) glavna/osnovna rečenica sadrži imenicu, imensku riječ ili skupinu (antecedent) na koju se odnosna rečenica odnosi ${ }^{22}$;

3) sadrži vezničku riječ (relativizator) kojom se uvrštava u glavnu rečenicu, a najučestaliji relativizatori jesu zamjenice sa sintaktičkom funkcijom koju iskazuju odgovarajućim morfološkim oblikom (koji/a/e), odnosni veznik (što) te veznički prilozi sa značenjem mjesta, vremena i načina;

4) u odnosnoj je rečenici sačuvana za antecedent sintaktičko-semantička i pragmatička funkcija;

5) antecedent i relativizator $\mathrm{u}$ kontaktnom su položaju u kojem antecedent prethodi relativizatoru, iz čega slijedi da je odnosna rečenica iza riječi na koju se odnosi.

Unatoč popriličnom broju obilježja tipološke i psiholingvističke studije potvrđuju da se odnosne rečenice među jezicima i ne razlikuju u mjeri u kojoj bi se to možda moglo očekivati (Andrews, 1985; Cuetos i sur., 1996; Hemforth i sur., 2015), što je jedan od već spomenutih razloga zašto se čine idealnima za ispitivanje sintaktičke obrade i varijacija u istoj među jezicima (Cuetos i sur., 1996). Od svih obilježja odnosnih rečenica, za potrebe ove disertacije najvažnije je razmotriti mogućnosti dvosmislene interpretacije tih rečenica u hrvatskome, istaknuti neke manjkavosti u opisima te se detaljnije osvrnuti na obilježja relativizatora i odnose kontaktnosti imenske skupine i relativizatora. To je nužno zbog obilježja odnosnih rečenica koje su dijelom ispitnih podražaja u ovom istraživanju.

U funkcionalnim se podjelama odnosnih rečenica izdvaja podjela na atributne rečenice $s$ izraženim antecedentom, slobodne rečenice bez izraženog antecedenta ili one kojima je antecedent neodređena zamjenica (Kordić, 1995: 187). Odnosne rečenice sa složenom imenskom skupinom kao antecedentom jesu one čija će se obrada analizirati u ovoj disertaciji jer svojim strukturno-značenjskim osobitostima mogu pružiti dodatan uvid u preferencije vezivanja na prvu ili drugu imenicu (ili čitavu NP), ovisno o osobitostima njihova odnosa. Silić i Pranjković (2005: 355-356) raspravljaju i o tipu odredbe u atributnim odnosnim rečenicama s obzirom na vrstu značenjskog odnosa između glavne i zavisne rečenice. Izdvajaju restriktivne i nerestriktivne rečenice, pri čemu se u restriktivnima zavisna surečenica odnosi na antecedent širega značenjskog opsega koji se postupno sužava, dok se nerestriktivne odnose na riječi užega značenjskog opisa. Takvo je određenje rezultatom uzajamnog utjecaja više čimbenika,

\footnotetext{
${ }^{22}$ Iako je antecedent najčešće imenica, vrlo rijetko antecedent može biti i, primjerice, posvojni pridjev, ali ova se mogućnost u slavenskim jezicima sve više gubi; mjesto posvojnoga pridjeva u toj funkciji zauzima genitiv. $\mathrm{O}$ posvojnom pridjevu kao antecedentu odnosne rečenice ni izvorni govornici ni suvremene gramatike nemaju jednoznačan stav (Marković, 2008).
} 
primjerice sadržaja i sastava antecedenta i odnosne rečenice, ali i znanja govornika o izvanjezičnoj stvarnosti te obilježjima konteksta. Tako će rečenica Ljudi koji su bolesni to će lako razumjeti zbog sadržaja zavisne surečenice i izvanjezičnoga znanja govornika svakako biti restriktivna jer nisu svi ljudi bolesni. Rečenica Ljudi, koji su smrtni, to će lako razumjeti će po ovom kriteriju biti nerestiktivna jer su svi ljudi smrtni (prema Silić i Pranjković, 2005: 356). Iz takvog određenja proizlazi da se govornici u interpretaciji oslanjaju na više razina obavijesti koje su u složenom odnosu međuovisnosti.

Dvosmislenost se $u$ opisima odnosnih rečenica u hrvatskome najčešće spominje isključivo s obzirom na svojstvo restriktivnosti. Katičić (1994: 69-70, 76; 2002: 469) navodi da će u slučaju dvosmislenosti točnu interpretaciju sugerirati redoslijed riječi, prozodijski naglasak u govoru, odnosno odvajanje dijelova rečenice zarezima u pismu ili pak vrsta determinatora (primjerice, Ona žena koja pije mnogo kave ima visok tlak naspram Moja žena, koja pije mnogo kave, ima visok tlak; Kordić, 1995: 89). Puno je rjeđe opisana dvosmislenost uzrokovana složenom imenskom skupinom koja prethodi relativizatoru u kojoj se obje imenice s njime slažu u rodu, broju i padežu, a ujedno i odgovaraju sadržaju zavisne surečenice (primjerice, Restoran hotela koji je lijepo uređen svojim izgledom iznenađuje goste; vlastiti primjer). Upravo se takve pojavnosti promatraju u istraživanjima preferencija vezivanja te mogu dati odgovor na pitanje na što se govornici hrvatskoga oslanjaju u nedostatku ostalih dostupnih obavijesti.

Budući da obilježja relativizatora u jezicima variraju, valja ih jasnije razlučiti i oprimjeriti u hrvatskome. Iako ta sredstva veze glavne i odnosne surečenice različiti autori grupiraju na različite načine, izdvajaju se skupine veznika i vezničkih riječi u koje se ubrajaju odnosne zamjenice, pridjevi i prilozi (Kordić, 1995; Pranjković, 2002; Barić i sur., 2005; Silić i Pranjković, 2005). U kontekstu psiholingvističkih istraživanja obrade odnosnih rečenica, autori svoju podjelu ograničavaju na relativizatore sa ili bez morfoloških obilježja kojima se može sugerirati točna interpretacija odnosne rečenice (Hemforth i sur., 1998; 2000a; 2000b). U skladu $\mathrm{s}$ time, izdvojit će se dva najčešća relativizatora kojima se odnosna rečenica uvodi u hrvatskome, a koji se razlikuju upravo s obzirom na dostupnost morfoloških obilježja.

Zamjenica koji najčešća je zamjenica kojom se u hrvatskome glavna rečenica povezuje s odnosnom. Budući da obuhvaća šire značenjsko polje od zamjenica uskoga određenja poput čiji, kakav, koliki itd., dozvoljava i najveći raspon antecedenata (Maček, 1970; Kordić, 1995). Zamjenički relativizator koji uvijek se s antecedentom slaže u rodu, broju i padežu. Drugi je 
najčešći relativizator nesklonjiva riječ što, čija je funkcija primarno veznička. ${ }^{23}$ Oba se ta relativizatora mogu odnositi na antecedente s obilježjem živo i neživo, ali samo koji u sebi nosi morfološka obilježja, tj. informacije o rodu i broju. Nesklonjivi relativizator što pojavljuje se uz iste antecedente kao i zamjenica koji, stoga su oni međusobno zamjenjivi (Pranjković, 2002: 85), a njihova je naizmjenična uporaba i stilski prikladna (Katičić, 2002). Iz navedenih razloga odnosne rečenice s izraženim antecedentom koje su u glavnu rečenicu uvedene relativizatorom što ne treba značenjski odvajati od onih uvedenih odnosnom zamjenicom koji (Raguž, 1994; Silić i Pranjković, 2005). Takve spoznaje opravdavaju uporabu obaju relativizatora u ispitnim podražajima u ovoj disertaciji.

Izvornome je govorniku jezika tumačenje odnosnih rečenica znatno olakšano kontaktnim položajem antecedenta i relativizatora (Štrkalj Despot, 2018). Kada kontaktni položaj ne bi bio pravilo, sročnost antecedenta i zamjenice bila bi jedinim ključem u tumačenju potencijalno složenih značenjskih odnosa. Ovako je i položaj imenice neposredno ispred relativizatora znakom da je baš ona, a ne neka druga imenica, antecedentom odnosne rečenice. Kontaktno je obilježje i otvorilo mogućnost uvođenja odnosne surečenice u glavnu relativizatorom koji nije nužno morfološki obilježen (što u hrvatskome). Kada se odstupi od kontaktnoga položaja dolazi do distaktnosti. Ona može biti uzrokovana različitim čimbenicima, ali je u kontekstu ove disertacije najvažnije spomenuti distaktnost uzrokovanu neglagolskim članom glavne rečenice koji je podređen antecedentu. Prema Kordić (1995: 264) između antecedenta i relativizatora može doći samo antecedentu podređeni član koji pripada istoj nominalnoj sintagmi, primjerice genitiv ili drugi tip odredbe. To odgovara složenim imenskim skupinama o čijim se odnosima raspravlja u okviru konstrualne hipoteze. U hrvatskome se jeziku unutar imenske skupine koja čini antecedent mogu nalaziti i riječi kojima se precizira sadržaj. Te riječi (determinatori) imaju ulogu determinacije ili atribucije i njima se na različite načine ostvaruje referiranje zamjenicama i riječju jedan izražavaju se pokaznost, posvojnost i neodređenost, a pridjevom se precizira sadržaj imenice (primjerice, majka jedne djevojčice i majka lijepe djevojčice).

U hrvatskome su jeziku u složenim imenskim skupinama u kojima se genitivnom dopunom izražava posvojnost ove riječi neizostavne jer je posvojni genitiv uobičajena tvorba gotovo isključivo ako uz njega stoji dodatak. U suprotnome se pripadnost najčešće iskazuje posvojnim pridjevima (Matasović, 2000; 2002; Kuna, 2002; 2012; Barić i sur., 2005; Marković, 2008).

\footnotetext{
${ }^{23}$ Kordić (1995) analizom korpusa tekstova različitih funkcionalnih stilova pronalazi da zamjenički relativizator koji i veznički relativizator što uvode otprilike $80 \%$ svih odnosnih rečenica. Navodi i da hrvatski pripada slavenskim jezicima u kojima je uporaba relativizatora što još uvijek očuvana, iako se primjećuje tendencija prorjeđivanja njegove uporabe.
} 
Iako drugu imenicu unutar imenske skupine u hrvatskome jeziku počesto smatramo podređenom, to jest dijelom sintagme u kojoj je prva imenica glavom, može se pojaviti dvojba prilikom tumačenja struktura u kojima se između antecedenta i relativizatora nalazi još jedna riječ istoga roda i broja.

S obzirom da je kontaktni položaj imenice i relativizatora najčešći, a ujedno dvije imenice istoga roda i broja bez izvanjezičnoga konteksta uzrokuju sumnju i dvosmislenost prilikom tumačenja rečenica, postavlja se pitanje kako će se one tumačiti s obzirom na svoje strukturnoznačenjske osobitosti. To opravdava uporabu upravo ovih rečenica $u$ istraživanju preferencija vezivanja u hrvatskome, kako bi spoznaje bile usporedive s istraživanjima u drugim jezicima. U nastavku iznosimo obilježja genitivnih dopuna i prijedložno-padežnih izraza u hrvatskome, budući da konstrualna hipoteza predviđa razlike $u$ vezivanju odnosne surečenice na odgovarajući antecedent, ovisno o sastavu i vrsti imenske skupine koja joj prethodi. 


\subsection{Genitivne dopune u hrvatskome}

Genitiv je u hrvatskome (kao i općenito u svim flektivnim jezicima) najčešći rekcijski padež imenica koji se poistovjećuje s atributnom ulogom. Dapače, češći je od svih ostalih kosih padeža zajedno, posebice u znanstvenome diskursu (Kuna, 2003). Imenske se skupine u najvećem broju slučajeva nalaze upravo u genitivu, neovisno o svojoj sintaktičkoj ulozi. Iznimno visoka čestotnost ovoga padeža i njegova mogućnost ulančavanja i linearizacije (vidi Kuna, 2003) upućuju na široke kontekstne i strukturno-značenjske okvire u kojima se on može pojaviti. U skladu s time, on ima i najšire i najopćenitije značenje (Silić i Pranjković, 2005). Njime se mogu izražavati prostorni i vremenski odnosi, odnosi pripadnosti, svojstva, izuzimanja, potjecanja, uzročno-posljedične povezanosti itd. (ibid.). Sukladno tematici disertacije, u ovome će poglavlju biti opisane i oprimjerene genitivne dopune imenskih skupina koje će biti dijelom odnosnih rečenica u istraživanju (posvojni genitiv, subjektni i objektni genitiv, genitiv cjeline i sadržaja, dijelni i objasnidbeni genitiv).

Kuna (2003) razlikuje netematski i tematski genitiv, pri čemu netematski podrazumijeva kontaktni položaj s glavnom ili upravnom imenicom (načelo priložnosti), dok tematski genitiv može stajati i iza nekog drugog genitivnog argumenta. U tome će slučaju leksička glava imenske skupine (prva imenica u složenoj NP) dodijeliti tematsku ulogu svojoj dopuni, tj. imenici u genitivu. U slučaju ulančavanja i nizanja genitiva, svaki će idući biti dopuna prethodnome, dakako ako se radi o gramatički ispravnoj konstrukciji (primjerice, pokretanje programa zapošljavanja invalida rada; prema Kuna, 2003: 247).

Tematski su genitivi posvojni, subjektni i objektni, i u hrvatskome je za njih karakteristična zamjenjivost s ostalim oblicima - posvojnim pridjevima i zamjenicama. Posvojnost je univerzalna jezična kategorija (Heine, 1997; Matasović, 2002) i isključivo je lingvistički pojam koji Kuna (2012) opisuje zrcalnim odnosom posjedovanja i pripadnosti. Ipak, ti su odnosi itekako složeniji od ove jednostavne sheme, što je razlogom postojanja brojnih podjela (primjerice, pripadnost po rodbinskom odnosu, vlasništvu i pridruživanju; Barić i sur., 2005; ili razlikovanje otuđive i neotuđive posvojnosti karakteristične za indoeuropske jezike; Heine, 1997; Matasović, 2002; Kuna, 2012). ${ }^{24}$ Van Valin (2001) posvojnost smatra zanimljivom, ali i donekle problematičnom jezičnom kategorijom, posebice u kontekstu odnosa zavisnosti. Iako

\footnotetext{
${ }^{24}$ Matasović (2002: 153) navodi da se obje ove vrste izražavaju istim gramatičkim konstrukcijama, ali razlikovanje ipak postoji na pragmatičkoj razini.
} 
se može činiti da je u odnosu posvojnosti jedan element nadređen drugomu te da posljedično odnos među elementima ne može biti dvosmjeran, on je ipak upravo takav. Naime, izostavljanjem jednog elementa te konstrukcije (posjedovatelja ili posjedovano), kategorija posvojnosti se gubi.

Ne postoji jedna sintaktička konstrukcija isključivo za izražavanje posvojnosti te se ona može izreći na više načina (Kuna, 2002). Za razliku od izricanja posvojnosti genitivom, u hrvatskome jeziku atributna posvojnost podrazumijeva i izricanje posvojnim pridjevom. Upravo se potonji oblik danas smatra prihvatljivijim (Kuna, 1999; Matasović, 2000; 2002; Barić i sur., 2005; Silić i Pranjković, 2005; Težak i Babić, 2005; Marković, 2008). Matasović (2000) čak navodi konkretna pravila zamjene genitivne dopune pridjevom. Sukladno tezama koje pronalazimo u Kuna (1999), Matasović (2000; 2002), Silić i Pranjković (2005), Težak i Babić (2005), genitivna je dopuna prikladniji izbor od posvojnoga pridjeva ako se uz genitiv nalazi apozicija ili atribut te ako posvojni pridjev ne preslikava značenje istovjetno onomu iskazanom genitivnom dopunom (primjerice, djeca cvijeća naspram *cvjetna djeca; značenjska analiza sintagmema prikazana je u Silić i Pranjković, 2005: 267-268). Marković (2008) i Majcenović (2016) smatraju da su genitivne dopune itekako i danas prisutne, unatoč tomu što se smatraju arhaičnima. Marković (2008) postavlja pitanje koliko se izvorni govornik doista vodi pravilima uporabe različitih oblika (primjerice, s obzirom na određenost/neodređenost; vidi Matasović, 2000), odnosno koliko ova pravila doista utječu na njegov jezični odabir u svakodnevnim situacijama.

Iako se besprijedložni genitiv može pojaviti i u prijedložnom obliku uz prijedlog od (posebice u ranome dječjem jeziku i razgovornom diskursu; Kuvač i Palmović, 2007; Kuna, 2012), glavnina hrvatske normativne literature zastupa ograničavanje uporabe toga prijedložnog oblika (Barić i sur., 2005; Silić i Pranjković, 2005). Prijedložni je oblik genitiva (od + genitiv) donekle opravdan ako imenice imaju obilježje neživo, dok bi ga trebalo izbjegavati ako imaju obilježje živo (primjerice, kvaka od vrata, ali ne i majka od prijateljice, već majka moje prijateljice ili majka prijateljice Ivane) (vidi Barić i sur., 2005; Silić i Pranjković, 2005; Težak i Babić, 2005). Prema Van Valin (2001) bez obzira na odabrani oblik posjedovano je gotovo uvijek glava konstrukcije (primjerice, Marijina knjiga; knjiga bake Marije). Ovo se ipak kudikamo usložnjava ako je sadržaj koji slijedi dvosmislen, što dokazuju i neujednačene preferencije govornika različitih, ali i istoga jezika.

Osim posvojnih genitiva, skupini besprijedložnih genitiva pripadaju i ablativni genitiv, dijelni ili partitivni genitiv, genitiv svojstva, slavenski genitiv, genitiv cjeline itd. (Kuna, 2002; Barić 
i sur., 2005; Silić i Pranjković, 2005). Posvojnim se genitivima nekada neispravno smatraju i genitiv cjeline, sadržaja, subjektni ili objasnidbeni genitiv (Kuna, 2002).

Subjektni genitiv označava vršitelja ili prouzročitelja radnje i nalazi se uz imenske riječi koje tu radnju obilježavaju. Najčešće su to imenice nastale od glagola i subjektni je genitiv tada rezultatom preoblike poimeničenja (pjevati $\rightarrow$ pjevanje; ptice pjevaju $\rightarrow$ pjevanje ptica; izvijestiti $\rightarrow$ izvještaj; predsjednik izvještava $\rightarrow$ izvještaj predsjednika). Ponekad se može preoblikovati u pridjev, ali upitna je potpuna istovjetnost značenja tih oblika (primjerice, izvještaj predsjednika naspram predsjednikov izvještaj).

Objektni genitiv označava predmet radnje te se, kao i subjektni genitiv, nalazi uz imenice koje obilježavaju tu radnju. Od subjektnoga se razlikuje po tome što prilikom preoblike u glagolski oblik genitiv dolazi u poziciju objekta (graditi $\rightarrow$ gradnja; gradi se kuća $\rightarrow$ gradnja kuće). U najvećem broju slučajeva preoblika u posvojni pridjev nije moguća (primjerice, *kućna gradnja).

Objasnidbeni genitiv pobliže objašnjava sadržaj imenice na koju se odnosi (primjerice, raspored predavanja).

Genitivom svojstva izražava se kakvo svojstvo, a sastoji se od obaveznoga atributa (primjerice, pjevač tamne kose).

Dijelni genitiv dolazi uz riječi koje označavaju količinu, mjeru i dio čega (primjerice, čaša vode).

Genitivom cjeline izriče se pripadnost dijela cjelini, pri čemu se može raditi o opipljivom, materijalnom (primjerice, krov zgrade) ili apstraktnom predmetu (primjerice, zakon šutnje).

Kako naglašava i Kuna (2002), teško je jasno razgraničiti kojoj vrsti pripada koji izraz. Iako stroga razgraničenja i nisu od presudne važnosti u ovom istraživanju, valja napomenuti da će navedene genitivne dopune biti dijelom ispitnih podražaja zbog potrebe za eksperimentalnom manipulacijom. Značenjski će se odnosi razmotriti prilikom interpretacije rezultata. 


\subsection{Prijedložno-padežni izrazi u hrvatskome}

I prijedložno-padežni izrazi dijelovi su ispitnih podražaja u eksperimentima kojima se provjerava jedna od postavki konstrualne hipoteze, ali o postanku prijedloga ili o detaljnoj analizi njihova značenja neće biti riječi. ${ }^{25}$ Naime, u istraživanjima sintaktičke obrade i preferencija vezivanja s obzirom na mogućnost tematskog označavanja prijedloga, strukture s genitivnim dopunama najčešće se uspoređuju sa strukturama u kojima se izražavaju socijativnost (prijedlog $s$ ) ili lokacija (različiti prijedlozi za označavanje lokacije). U nastavku će se stoga iznijeti osnovna obilježja upravo tih prijedloga u hrvatskome i opravdat će se njihova uporaba u istraživanju.

Prijedlozi su suznačne riječi kojima se izriču i pobliže označavaju odnosi među predmetima i događajima (Silić i Pranjković, 2005). Naziv prijedlog govori da se oni nalaze ispred riječi s kojom su u vezi i s kojom čine prijedložni izraz (Babić i sur., 2005) ${ }^{26}$, dok suznačnost upućuje na uopćenu, relacijsku ulogu uspostavljanja međusobnog odnosa među riječima (Silić i Pranjković, 2005). Osnovna je podjela ona na jednostavne i složene (Hagège, 2010), odnosno na primarne (prave, neproizvedene ili podrijetlom nemotivirane) i sekundarne (neprave, proizvedene ili podrijetlom motivirane) prijedloge (Babić i sur., 2005; Silić i Pranjković, 2005). Iako ni hrvatske gramatike nisu u potpunosti suglasne koje prijedloge valja uključiti u koju skupinu (više vidi u Matovac, 2013; Katunar, 2015), u prvu se u pravilu ubrajaju prijedlozi čije se značenje ne može izvesti iz koje druge riječi: primjerice, $b e z, d o, i z, u, n a, p o, p o d, o k o, \ldots .$. dok drugu čine izvedeni i složeni prijedlozi kao što su glagolski prilozi ili složeniji prijedložnopadežni izrazi. Neki se pravi prijedlozi mogu slagati s više padeža $(u, n a, z a, o, p o, s, \ldots)$, a neki samo s jednim (uz, pri, prema, ...).

S obzirom na svoje odnose s padežima prijedlozi mogu imati dimenzionalna i nedimenzionalna značenja. Dimenzionalni prijedlozi podrazumijevaju prostorna (to su ujedno njihova najčešća, osnovna značenja) i vremenska značenja. Nedimenzionalni prijedlozi podrazumijevaju složenije logičke odnose pripadnosti, načina, uzročnosti i sl. U nastavku iznosimo razloge uporabe isključivo jednodimenzionalnih prijedloga za izražavanje lokacije ( $u$ i $n a) \mathrm{u}$ istraživanju, i to povrh ostalih prostornih prijedloga i povrh prijedloga $s$.

\footnotetext{
${ }^{25} \mathrm{O}$ razlikama između tradicionalnih i kognitivnih pristupa podjeli prijedloga, kao i o kritikama tih podjela detaljno piše Matovac (2013), dok Katunar (2015) pruža opis različitih pristupa i detaljnu analizu sprege sintaktičkosemantičkih obilježja prijedloga u hrvatskome.

${ }^{26}$ Rijetko se mogu nalaziti i nakon riječi na koju se odnose (poslijelozi; Silić i Pranjković, 2005).
} 
Uporaba je prijedloga $u$ i na u ovoj disertaciji ograničena na njihovo osnovno prostorno značenje, koje se ostvaruje kada se slažu s padežom lokativom. Usprkos tomu što se mogu slagati i s akuzativom (prijedlog $u$ i s genitivom), prijedložni izrazi u tim konstrukcijama ocrtavaju puno složenije odnose, čime se narušava kontrola i mogućnost interpretacije ishoda istraživanja u okviru ranije iznesenih teorijskih postavki. ${ }^{27}$ Nadalje, budući da se njima iskazuje jednoznačna jednodimenzionalna (statična) lokacija, izbjegava se zadiranje u složenije značenjske razlike između nedirektivne (statične) i direktivne (dinamične) lokacije. Prijedložnim izrazima $u$ ili $n a+$ lokativ izražava se smještaj predmeta i njegovo mirovanje u granicama drugoga predmeta, čime su isključene dimenzije blizine i kretanja (vidi Pranjković, 1992; 2009; Šarić, 2008; Matovac, 2013; Katunar, 2015).

Uporaba prijedloga za izražavanje socijativnosti u okviru preferencija vezivanja u odnosnim rečenicama u hrvatskome jeziku nije idealna, a najmanje su dva razloga tome. Prvi razlog najbolje će ocrtati primjer u nastavku (Papadopoulou, 2006: 109):

(8) The director looked at the teacher of / with the pupil that was...

[ hrv. Direktor je pogledao učiteljicu od učenice / s učenicom koja je bila ... ].

Navedene su rečenice primjer potpuno ujednačenih struktura bez (of) i s prijedlogom s mogućnošću tematskog označavanja (with) kojima je ostvarena idealna eksperimentalna manipulacija s ciljem ispitivanja postavki konstrualne hipoteze. Unatoč tomu, izvornim govornicima hrvatskoga jezika nije prirodna (vidi hrv. prijevod rečenice (8)). Iako narušavanje strukture i prirodnosti jezika za potrebe eksperimentalnoga nacrta može olakšati konceptualnu pripremu istraživanja, ujedno je i uzrokom neispravnih i manjkavih spoznaja. Drugi je razlog izbjegavanja uporabe prijedloga $s$ u rečenicama u ovoj disertaciji njegova složena i ograničena uporaba u hrvatskome. Za razliku od drugih jezika, u hrvatskome postoje različita pravila njegove uporabe u strukturama $u$ kojima se označava društvo naspram onih u kojima se označava kakvo sredstvo. Zaključno, budući da su i društvo i lokacija značenjske dimenzije koje podrazumijevaju združenost i kontakt predmeta u suodnosu (Matovac, 2013), a prva u hrvatskome podrazumijeva i neka ograničenja, strukture s prijedložnim izrazima u ovoj će disertaciji izražavati isključivo odnose statične lokacije.

${ }^{27}$ O izvedenim značenjima prijedloga $u$ i na raspravlja primjerice, Šarić $(2006 ; 2008)$, a na drugačiju obradu tih izraza u hrvatskome upućuju i rezultati pilot istraživanja Matić (2018). 


\section{OSTALI ČIMBENICI KOJI UTJEČU NA SINTAKTIČKU OBRADU}

Složenost jezične obrade ne trpi zanemarivanje ostalih čimbenika koji utječu na tumačenje rečenice, poput opsega radnoga pamćenja pojedinca te obilježja jezičnih struktura, stoga će i oni biti predstavljeni. Činjenica da preferencije vezivanja i tumačenje odnosnih rečenica ovise o nizu nejezičnih i jezičnih čimbenika, o obilježjima ispitnih podražaja i samom eksperimentalnom nacrtu, dodatna je potvrda slojevitosti i složenosti mehanizama u pozadini jezične obrade.

U nastavku će se navesti čimbenici koje se uzelo u obzir prilikom sastavljanja ispitnih podražaja u ovoj disertaciji jer je njihov utjecaj na jezičnu obradu i preferencije govornika potvrđen u nizu istraživanja, bez obzira iz kojeg su ishodišnoga modela ona polazila. Na taj se način izbjegavaju teorijska i istraživačka pristranost ili pogreške u istraživanju te se umanjuje mogućnost donošenja manjkavih zaključaka na temelju dobivenih rezultata. Iako je u mnogim znanstvenim disciplinama određeni stupanj pristranosti nemoguće izbjeći, prilikom planiranja istraživačkoga nacrta potrebno je iste biti svjestan, svesti ju na najmanju moguću razinu te se na nju osvrnuti prilikom interpretacije rezultata (Forster, 2000; Kuperman, 2015). 


\subsection{Radno pamćenje}

Radno pamćenje jest složeni konstrukt koji se odnosi na mentalni sustav odgovoran za aktivno zadržavanje obavijesti prilikom istovremene obrade th istih, ili nekih drugih, obavijesti (Baddeley i Hitch, 1974; Daneman i Carpenter, 1980). Drugim riječima, to je višekomponentni sustav koji uključuje integraciju, upotpunjavanje, nadgledanje i kombiniranje različitih vrsta obavijesti od kojih su neke i ometajuće (Conway i sur., 2005; Rončević Zubković, 2010). Iako je radno pamćenje jedan od najviše istraživanih koncepata u kognitivnoj psihologiji i srodnim disciplinama, zbog različitih teorijskih postavki i pristupa u tumačenju (a posljedično i terminoloških te metodoloških nesustavnosti u njegovu određenju i načinu mjerenja), njegov se ustroj uvijek nanovo istražuje.

Godinama se nastojalo doći do odgovora na pitanja poput: je li sustav jedinstven ili postoji više podsustava s obzirom na načine skladištenja obavijesti (primjerice, Baddeley, 1990; 2003), postoje li razlike u pasivnoj i aktivnoj pohrani obavijesti, tj. koji je proces u većoj mjeri povezan sa složenijim kognitivnim aktivnostima (primjerice, Daneman i Carpenter, 1980; Turner i Engle, 1989) i koje su izvršne funkcije u pozadini radnoga pamćenja, odnosno koje od njih u najvećoj mjeri utječu na raspon, a posljedično i izvedbu osobe - ažuriranje i nadgledanje obavijesti, inhibicija odgovora, prebacivanje ili kontroliranje pažnje (Engle, Kane i Tuholski, 1999; Miyake i sur., 2000). Ustanovljeno je, primjerice, da osobe s većom mogućnošću aktivne pohrane te kontrole pažnje i zadržavanja fokusa na obavijestima važnima za zadatak (primjerice, broju riječi ili grafema koje je potrebno upamtiti) doista imaju i veći opseg radnoga pamćenja (Engle i sur., 1999).

Radno pamćenje kao konstrukt ima veliku ulogu u oblikovanju općih suvremenih kognitivnih modela (Anderson i Lebiere, 1998), ali je uključeno i u široki raspon složenih ponašanja poput rasuđivanja, rješavanja problema i donošenja odluka (Engle, 2002) te je prediktor jezičnoga razumijevanja, proizvodnje i aktivnosti koje su izravno ili neizravno posredovane jezikom (Daneman i Carpenter, 1980; 1983; Friederici i sur., 1998; Engle, 2002; Swets i sur., 2007; Traxler, 2007; Rončević Zubković, 2010).

O konstruktu radnoga pamćenja raspravlja se u svim područjima psihologije - kognitivnoj, kliničkoj, socijalnoj, razvojnoj i obrazovnoj - a u rasprave i mjerenja postupno su se uključile i psihologiji srodne discipline poput lingvistike i logopedije. Ustanovljene su, primjerice, značajne veze između ograničenoga raspona radnoga pamćenja, tj. ograničene mogućnosti 
zadržavanja i obrade jezičnih obavijesti, i kasnijega školskog uspjeha (Alloway, 2009) ili pak razvojnih jezičnih teškoća i disleksije (Gathercole i sur., 2006).

Unatoč teorijskoj i znanstvenoj utemeljenosti te opravdanosti uporabe ove mjere i u ostalim područjima i poljima znanosti, zadatci se ponekad prevode, primjenjuju, boduju i tumače na pogrešan način, a posljedično su i zaključci o valjanosti i pouzdanosti mjera te samom utjecaju radnoga pamćenja na fenomen koji se ispituje nekonzistentni (Conway i sur., 2005; Foster i sur., 2015). Conway i sur. (2005) autorima su sveobuhvatnoga preglednog rada o konstruktu radnoga pamćenja i zadatcima kojima se ono mjeri. U radu iznose potvrde o utemeljenosti, opravdanosti i prikladnosti zadataka raspona radnoga pamćenja koji se najčešće primjenjuju, istovremeno upozoravajući na moguće opasnosti prilikom njihove provedbe i tumačenja. Iznose optimalne mjere koje ovise o svrsi ispitivanja, kao i metodološke savjete o provedbi i načinima analize s ciljem donošenja valjanih zaključaka u skladu s istraživačkim pitanjem.

Upravo su te znanstveno utemeljene činjenice o konstruktu radnoga pamćenja bile polazišnom točkom u odabiru mjera raspona radnoga pamćenja te načinu bodovanja i tumačenja rezultata radi homogeniziranja uzorka u ovome istraživanju. Budući da je u radu naglasak na sintaktičkoj obradi, a individualne razlike u rasponu radnoga pamćenja varijabla koja se kontrolira, u nastavku će se prikazati povezanost raspona radnoga pamćenja i jezične obrade. Prikazat će se neke od mjera, kao i relevantne spoznaje iz prijašnjih istraživanja obrade odnosnih rečenica.

\subsubsection{Radno pamćenje i jezična obrada}

Daneman i Carpenter (1980) prve su pretpostavile da individualne razlike u rasponu pamćenja u jezičnom razumijevanju pri čitanju nisu uzrokovane razlikama u rasponu pasivne pohrane, već razlikama u funkcionalnom rasponu pamćenja (mogućnosti istovremenoga skladištenja i obrade obavijesti te naknadnoga prisjećanja). Smatrale su da vješti čitatelji imaju bolju vještinu obrade, a posljedično i veću mogućnost pohrane obavijesti. Predstavile su novu mjeru radnoga pamćenja koja nije zahtijevala isključivo pasivnu pohranu i prisjećanje obavijesti poput nizova znamenki ili riječi (mjera kratkoročnoga pamćenja), već je podrazumijevala aktivnu ulogu pojedinca u procesu pamćenja. Razvijenu mjeru raspona verbalnoga radnog pamćenja nazvale su zadatkom raspona radnoga pamćenja pri čitanju (izv. eng. reading span task). Načini provedbe i bodovanja ovoga zadatka mnogobrojni su, ali je u njihovoj pozadini ista logika: sudionik čita nizove rečenica, a nakon svakoga pročitanog niza istim redoslijedom ponavlja posljednje riječi u tim rečenicama. Duljina rečenica (u originalnoj, i većini drugih inačica) 
varira od 13 do 16 riječi, a rečenice se prikazuju na karticama ili na zaslonu računala u nizovima od dvije do šest rečenica po prikazu. Kao mjera raspona najčešće se uzima broj točno upamćenih riječi ${ }^{28} \mathrm{U}$ naknadnim je inačicama razvijen i slušni test u kojem sudionik sluša rečenice i potom ponavlja posljednje riječi koje je čuo/čula, a autorice su postupno dodale i ometajuću komponentu zadatka (takozvani distraktor ili ometajući čimbenik) u kojoj se od sudionika traži da nakon čitanja/slušanja rečenica procijeni i njihovu točnost (s obzirom na enciklopedijsko znanje). Ovime se sprječava mogućnost razvijanja olakšavajuće strategije usmjeravanjem isključivo na posljednje riječi u rečenici, budući da su sudionici „prisiljeni““ aktivno sudjelovati, odnosno s razumijevanjem čitati/slušati čitave rečenice.

U takvim jezično zasićenim zadatcima duljina riječi u ispitnim česticama i njihova čestotnost ili poznatost, prozodija i naglasni sustav, kao i samo trajanje zadatka te način njegove prezentacije također utječu na izvedbu pojedinca (Conway i sur., 2005; Omaki, 2005). Iz tih je razloga ove čimbenike potrebno pažljivo kontrolirati. Jednako je bitno same mjere i čestice jezično prilagoditi, a ne ih izravno prevoditi iz jezika u jezik (van den Noort i sur., 2008). To počesto obeshrabruje istraživače koji radije pribjegavaju izravnomu prevođenju složenih mjera ili primjeni mjera kratkoročnoga pamćenja (poput jednostavnoga ponavljanja nizova grafema, riječi, ne-riječi ili znamenki), bez obzira na konkretno istraživačko pitanje (Foster i sur., 2015), što može imati nepovoljan utjecaj na interpretaciju rezultata i/ili odabir uzorka, tj. sudionika istraživanja.

Brojna su istraživanja opravdala i potvrdila povezanost složene mjere raspona radnoga pamćenja s jezičnim razumijevanjem i obradom. Potvrđena je povezanost te mjere $s$ prisjećanjem činjenica iz pročitanoga teksta, određivanjem antecedenta na koji se odnosi zamjenica (Daneman i Carpenter, 1980), brzinom oslanjanja na morfološke obavijesti prilikom obrade dvosmislenih rečenica (Friederici i sur., 1998), načinom i brzinom razrješavanja dvosmislenosti u složenim rečenicama (Kemper, Crow i Kemtes, 2004), kao i s odabirom referenta i preferencijama vezivanja u odnosnim rečenicama u djece i odraslih (Mendelhson i Pearlmutter, 1999; Felser i sur., 2003; Swets i sur., 2007; Traxler, 2007; Payne i sur., 2014). Unatoč tomu opravdano se postavilo pitanje mjeri li zadatak raspona radnoga pamćenja pri čitanju doista nezavisni resurs radnoga pamćenja ili je on jednostavno mjera učinkovitosti jezične obrade. Drugim riječima, jesu li umjerene i visoke korelacije između te mjere i razumijevanja pri čitanju jednostavno uzrokovane činjenicom da su oba zadatka pod utjecajem

\footnotetext{
${ }^{28}$ Mogućnosti bodovanja i utjecaj odluke ispitivača na konačni rezultat i tumačenje detaljno su opisani u Conway i sur. (2005).
} 
jednakih čimbenika poput iskustva u jezičnoj obradi, verbalne sposobnosti i iskustva u čitanju (Turner i Engle, 1989; Engle i Conway, 1998; MacDonald i Christiansen, 2002; Conway i sur., 2005).

Upravo su iz toga razloga razvijene nešto drugačije složene mjere kojima se također procjenjuje raspon verbalnoga radnog pamćenja i povezane su s jezičnom obradom, ali nisu u potpunosti uvjetovane samom jezičnom sposobnošću. Drugim riječima, mjere u čijim zadatcima čestice nisu jezično prezasićene. To otklanja mogućnost da je bolja izvedba pojedinca (veći raspon) jednostavno rezultatom njegova/njezina iskustva u čitanju, ali neminovno postavlja druge izazove jer izvedba može ovisiti o umješnosti u drugim vještinama, primjerice računanju. Primjer takvoga novorazvijenog zadatka jest zadatak raspona radnoga pamćenja pri računanju (izv. eng. operation span task; Turner i Engle, 1989; i njegove inačice, primjerice Engle, Cantor i Carullo, 1992; Unsworth i sur., 2005; Foster i sur., 2015). U zadatku pojedinac nastoji upamtiti niz nepovezanih riječi (ili grafema) koje se pojavljuju na kartici ili zaslonu računala, istovremeno rješavajući jednostavne matematičke zadatke. Nakon nekoliko čestica čiji se broj postupno ili nasumično povećava, osoba se pokušava dosjetiti točnoga redoslijeda prikazanih riječi ili grafema. Unsworth i Engle (2007) nizom su meta-analiza pokazali da zadatak doista mjeri jednake procese kao i zadatak raspona pri čitanju te da predstavlja valjanu mjeru raspona verbalnoga pamćenja. U umjerenoj je do visokoj korelaciji s jezičnim razumijevanjem i potvrđeno je da se osobe $s$ različitim rasponom radnoga pamćenja mjerenog ovim zadatkom doista razlikuju u raznim segmentima sintaktičke obrade (Nicenboim i sur., 2016), dok dio varijance zadatak dijeli i s testovima opće inteligencije (Conway, Kane i Engle, 2003; Conway i sur., 2005). Prednosti uporabe upravo ovoga zadatka uglavnom su metodološke naravi.

Već je spomenuto da zadatak raspona radnoga pamćenja pri čitanju mjeri sposobnost pojedinca da manipulira jezično zasićenim sadržajem, zbog čega povezanost te mjere s jezičnom obradom nije iznenađujuća (Engle i Conway, 1998; MacDonald i Christiansen, 2002). Valjana mjera raspona radnoga pamćenja trebala bi biti dobar prediktor viših kognitivnih funkcija i obrade te kao takva ne bi smjela biti ovisna o zadatku. Upravo se to postiže uporabom numeričkoga zadatka (Turner i Engle, 1989).

Zadatci verbalnoga radnog pamćenja potvrdili su značajnu umjerenu pozitivnu povezanost raspona radnoga pamćenja i razumijevanja. Oba navedena zadatka i u međusobnoj su korelaciji što pokazuje da dijele dio zajedničke varijance u objašnjenju jezičnoga razumijevanja i obrade. Faktorske su analize dodatno potvrdile da su rezultati na primarno verbalnim i primarno numeričkim zadatcima zasićeni istim faktorom (Oberauer i sur., 2000). Ipak, visoka unutarnja 
konzistentnost čestica u zadatku raspona radnoga pamćenja pri računanju, njegova valjanost i pouzdanost pri ponovljenim mjerenjima, pa i metodološke prednosti opisane u preglednim radovima i meta-analizama (Conway i sur., 2005; Unsworth i sur., 2005) opravdavaju uporabu upravo te mjere kao valjane mjere raspona radnoga pamćenja (Lu, 2015).

6.1.2. Utjecaj raspona radnoga pamćenja na sintaktičku obradu i preferencije vezivanja

Nakon prikaza složenoga konstrukta radnoga pamćenja i načina na koji se ono može mjeriti, slijedi i prikaz istraživanja čiji rezultati potvrđuju da raspon radnoga pamćenja utječe na način na koji pojedinci obrađuju, odnosno razumijevaju rečenice. Istraživanja su umnogome kontradiktorna zbog čega je konačne zaključke, ili barem inicijalne pretpostavke, o tome kakva je sintaktička obrada osoba $s$ većim rasponom radnoga pamćenja u odnosu na onu osoba $s$ manjim rasponom, nezahvalno donositi. Ipak, istraživanja o povezanosti individualnih razlika u rasponu radnoga pamćenja s obradom i tumačenjem rečenica sve su brojnija, a njihovi se ishodi tumače u okviru različitih teorija. Logačev i Vasishth (2016) smatraju da povezivanje imenica ili složenih imenskih skupina s odnosnom rečenicom koja slijedi uključuje njihovo aktivno prizivanje iz pamćenja, odnosno ponovnu aktivaciju memorijskoga traga (izv. eng. memory trace). Za pretpostaviti je da će uspješnost u aktivaciji i prizivu ovisiti o dostupnosti imenica, o složenosti i duljini rečenice te o strukturno-značenjskim osobitostima imenica, odnosno njihovom međusobnom odnosu. Tako će se obrada odnosnih rečenica sa složenim imenskim skupinama u kojima zavisna surečenica modificira bližu imenicu razlikovati od obrade rečenica u kojima modificira onu udaljeniju (Vasishth i Lewis, 2006) naprosto jer je memorijski trag u tim uvjetima različit, odnosno jer je drugačija narav njegove ponovne aktivacije. U slučaju dvosmislenih rečenica u kojima odnosna surečenica može modificirati oba antecedenta u složenoj imenskoj skupini, aktivirat će se trag za oba. Prema tim bi tvrdnjama osobe $\mathrm{s}$ većim rasponom radnoga pamćenja trebale u svim uvjetima imati bolju mogućnost priziva. Drugim riječima, njihova bi sintaktička obrada trebala biti brža i iziskivati manje obradbenoga napora, neovisno o odnosima imenica unutar imenske skupine i o vrsti rečenice. Brojna su istraživanja potvrdila da se osobe s različitim izvedbama na zadatcima raspona radnoga pamćenja razlikuju i u načinima obrade (primjerice, Just i Carpenter, 1992; MacDonald, Just i Carpenter, 1992; Van Gompel i Pickering, 2007), pri čemu su se dobivene razlike pripisale prvenstveno mogućnostima zadržavanja različitih obavijesti dostupnih $\mathrm{u}$ rečenicama te ponovne aktivacije memorijskoga traga. Ipak, rezultati istraživanja o utjecaju 
raspona radnoga pamćenja na preferencije vezivanja $u$ odnosnim rečenicama nisu samo nedosljedni, već su i u potpunosti oprečni.

Payne i sur. (2014) proučavali su utjecaj raspona radnoga pamćenja na preferencije u obradi, pri čemu su sudionici bili mlađe osobe i osobe starije životne dobi. Rezultati istraživanja pokazali su opću preferenciju vezivanja na bližu imenicu, ali je ona bila umjereno posredovana rasponom, pri čemu su najjači efekti nađeni u najstarijih sudionika. Autori su zaključili da postoje razlike u načinu na koji razumijevamo rečenice, ali da se razlike povećavaju starenjem i postupno u sve većoj mjeri postaju ovisne o rasponu radnoga pamćenja.

Utjecaj raspona radnoga pamćenja na preferencije vezivanja u različitim dobnim skupinama potvrdili su i Felser i sur. (2003). Rezultati njihovog istraživanja pokazali su da je sintaktička obrada više posredovana pamćenjem u djece predškolske dobi negoli u odraslih osoba, u kojih je ona u većoj mjeri pod utjecajem strukturnih i značenjskih obilježja ispitanih struktura nego navedenih nejezičnih čimbenika. Djeca s većim rasponom radnoga pamćenja češće su pokazivala preferencije vezivanja na prvu imenicu neovisno o odnosu imenica koje su prethodile odnosnoj zamjenici (povezane prijedlozima of i with (eng.)), dok su se odrasli pak, neovisno o rasponu pamćenja, oslanjali na strukturno-značenjske čimbenike. Autori su zaključili da postoje razvojne promjene u jezičnoj obradi te da se s porastom dobi postupno smanjuje kognitivni napor uvjetovan potrebom za oslanjanjem i na nejezične čimbenike prilikom obrade. Posljedično brzina obrade i mogućnost integracije različitih obavijesti rastu. Ako se njihovo istraživanje dovede u vezu s onim Payne i sur. (2014), postaje izgledno da se starenjem obradbeni napori ponovno povećavaju te da se starije osobe postupno opet počinju oslanjati i na druge kognitivne resurse u sintaktičkoj obradi.

Omaki (2005) je u iscrpnom istraživanju uporabom mjera u odgođenom i stvarnom vremenu pokazao da odrasle osobe urednih jezičnih sposobnosti i s većim rasponom radnoga pamćenja imaju preferenciju vezivanja na bližu imenicu, a one s manjim rasponom na dalju. Ipak, efekt je pronađen samo $u$ istraživanjima u odgođenom vremenu, dok mjere u stvarnom vremenu koje ocrtavaju procese u trenutku obrade (tijekom čitanja rečenica) nisu pokazale značajne razlike u obradi među sudionicima. Budući da je mjera u stvarnom vremenu u tom istraživanju bila čitanje vlastitom brzinom, autor poziva na uporabu profinjenijih metoda poput praćenja pokreta očiju kako bi se premostili nedostatci nedovoljno precizne metodologije. O manjkavostima i prednostima metoda u istraživanjima sintaktičke obrade više će riječi biti u poglavlju 7. Načini ispitivanja preferencija vezivanja na 75. stranici ove disertacije. 
Omaki je tako potvrdio istraživanje Mendelhson i Pearlmuttera (1999) čiji su rezultati na zadatku prosudbe pokazali da preferencije, osim o jezičnim čimbenicima, ovise i o nejezičnima, odnosno da postoje i individualne razlike u sintaktičkoj obradi. Njihovo je istraživanje pokazalo da osobe s manjim rasponom radnoga pamćenja imaju preferenciju vezivanja na dalju imenicu, čime su još jednom doveli u pitanje načelo kasnoga zatvaranja ili recentnosti. S druge strane, $\mathrm{u}$ ponovljenom istraživanju u stvarnom vremenu, rezultati su pokazali preferencije prema bližoj imenici. Osobe s većim rasponom imale su jednaku sposobnost ponovne aktivacije obiju imenica i nisu pokazivale nikakve posebne preferencije. Autori zaključuju da nerazmjer u rezultatima mnogih prethodnih istraživanja preferencija vezivanja ${ }^{29}$, a koji se uglavnom objašnjava jezičnim čimbenicima, može biti posljedica nedovoljno ujednačenoga uzorka sudionika, odnosno nedovoljne kontrole njihova raspona radnoga pamćenja. Kako zbog kontradiktornih rezultata u dvama provedenim eksperimentima nisu bili u mogućnosti donositi konačne zaključke, autori pozivaju barem na kontrolu ove varijable u budućim istraživanjima. Traxler (2007) je složenim mjerama i statističkim analizama u istraživanju provedenom u stvarnom vremenu (metodom praćenja pokreta očiju) također pokazao da odrasli s manjim rasponom pamćenja modifikaciju češće pripisuju posljednjoj imenici unutar NP, a oni s većim, prvoj. Sličnim su istraživanjem u odgođenom vremenu u engleskome i nizozemskome Swets i sur. (2007) pokazali potpuno suprotno. Iznijeli su objašnjenje da su navedene razlike u obradi uvjetovane različitim načinima prozodijske segmentacije rečeničnih dijelova, a koji su neizravno posredovani rasponom radnoga pamćenja. Friederici i sur. (1998) smatraju da sve moguće razlike u sintaktičkoj obradi osoba s manjim i većim rasponom radnoga pamćenja postaju razvidne samo u slučaju vrlo dugih i složenih rečenica, tj. pod velikim opterećenjem. U suprotnome, tvrde autori, razlika u obradi nema.

Navedena istraživanja onemogućuju donošenje konačnih zaključaka o stvarnoj naravi utjecaja raspona radnoga pamćenja na sintaktičku obradu, iako ona očito postoji. Upravo je iz tih razloga $\mathrm{u}$ istraživanjima preferencija vezivanja barem za početak potrebno osigurati homogenost uzorka, tj. sudionika ispitivanja, kontrolirajući njihov raspon radnoga pamćenja.

Osim toga, zamjetna je i ovisnost rezultata o metodologiji upotrijebljenoj u istraživanju. Naime, sam istraživački nacrt i način provedbe istraživanja, ali i kompleksnost i duljina ispitnih podražaja, mogu utjecati na rezultate. Zaključujemo stoga da je u pripremi valjanoga nacrta nužno kontrolirati što je moguće više čimbenika, a varirati samo one koji se ispituju.

\footnotetext{
${ }^{29}$ Preferencije znaju varirati od 10-80\% (vidi Frazier, 1990; Dussias i Sagarra, 2007; Hemforth i sur., 2015; ...)
} 


\subsection{Obilježja jezičnih struktura}

Osim raspona radnoga pamćenja sudionika istraživanja, na sintaktičku obradu uvelike utječu i obilježja struktura koje se ispituju, izuzev onih o kojima se raspravlja u okviru konstrualne hipoteze. U ovome će se dijelu pružiti osvrt na neka od njih, primjerice na duljinu rečenica, subjektni ili objektni položaj imenske skupine unutar odnosne rečenice, obilježja samih imenica (primjerice, konkretnost i živost) i relativizatora koji prethodi odnosnoj surečenici te, naposljetku, sadržaju odnosne surečenice (tj., eksperimentalnoj manipulaciji strukturnim ili značenjskim obilježjima s ciljem razrješavanja početne dvosmislenosti). Nedovoljna kontrola navedenih čimbenika u prijašnjim istraživanjima jedan je od uzroka oprečnih i nesustavnih spoznaja o sintaktičkoj obradi.

\subsubsection{Duljina rečenica}

Nekoliko je istraživanja promatralo utjecaj duljine odnosne surečenice na način na koji ju govornici u konačnici tumače. Istraživanja su, osim u engleskome (Quinn, Abdelghany i Fodor, 2000), provedena i u arapskome (Abdelghany i Fodor, 1999), francuskome (Pynte i Colonna, 2000), njemačkome (Hemforth i sur., 2015), španjolskome (Hemforth i sur., 2015) te hrvatskome jeziku (Lovrić i sur., 2001). Rezultati su ujednačeni, čak i među jezicima koji ne dijele mnogo strukturnih obilježja. Oni općenito potvrđuju povezanost duljine odnosne surečenice i preferencija vezivanja, $i$ to na način da je vjerojatnost vezivanja na prvu imenicu unutar NP veća što je odnosna surečenica dulja. Što je odnosna surečenica kraća, izglednija je pojava učinka lokalnosti ili recentnosti, tj. vezivanja na posljednju imenicu unutar NP (Hemforth i sur., 2015). Takve spoznaje govore u prilog hipotezi implicitne prozodije (Fodor, 1998; 2002) jer potvrđuju da će dulja sastavnica vjerojatno biti zasebna prozodijska jedinica. Rezultati su zanimljivi i zato što upućuju da među jezicima, neovisno o njihovim strukturnim obilježjima, ipak postoje i neke sličnosti u mehanizmima koji su u pozadini sintaktičke obrade (Hemforth i sur., 2015).

Iako se čini da je navedene tvrdnje jednostavno provjeriti, eksperimentalne su mogućnosti donekle ograničene. Primjerice, uspoređivanje načina na koji se obrađuju dulje i kraće odnosne surečenice gotovo je nemoguće provesti metodom praćenja pokreta očiju. U takvim se istraživanjima sve riječi u rečenici moraju na zaslonu računala prikazati istodobno u jednom retku. Ako je rečenica dulja, neizbježno će biti prikazana u nekoliko redaka. Time se gubi 
kontrola nad pokretima sudionikovih očiju koje se počinju kretati u svim smjerovima, što otežava analizu rezultata mjerenja (više u poglavlju 7.2. Metode u stvarnom vremenu). Unatoč tomu, istraživanja upućuju na značajan utjecaj duljine rečenice na način na koji će se ista protumačiti, stoga bi duljinu rečenica i ključnih dijelova koji se ispituju svakako trebalo kontrolirati.

\subsubsection{Položaj složene imenske skupine}

Već je spomenuto kako su proturječni rezultati istraživanja, čak i u istome jeziku, potaknuli nova pitanja o uzrocima nedosljednosti. Jedan je od uzroka zasigurno položaj složene imenske skupine unutar odnosne rečenice. Naime, u nekim su se istraživanjima ciljane imenske skupine nalazile u subjektnom položaju u rečenici, dok su u drugima one bile u objektnom položaju. Traxler i sur. (1998) u svoje su istraživanje provedeno u engleskome jeziku uključili samo rečenice s imenskim skupinama u subjektnom položaju (primjerice, The son of the driver that had the moustache was pretty cool ili The steak with the sauce that was tasty didn't win the prize; Sin øod vozača koji je imao brkove bio je prilično cool ili Odrezak s umakom koji je bio ukusan nije osvojio nagradu). Carreiras i Clifton (1999) u svome su pak istraživanju provedenom u španjolskome i engleskome jeziku ispitivali preferencije vezivanja u rečenicama $\mathrm{s}$ imenskim skupinama u objektnom položaju (primjerice, Someone shot the servant of the actor who was divorced; Netko je upucao slugu ood glumca koji je bio rastavljen). Iako se rezultati tih dvaju istraživanja nisu izravno uspoređivali, pa nedostatak statističkih analiza ne dozvoljava donošenje konačnih zaključaka o uzrocima različitih spoznaja, sami ih autori s oprezom pripisuju upravo razlici u materijalima, odnosno ispitnim podražajima (vidi Traxler i sur., 1998: 574).

Hemforth i sur. (2015) ispitali su utjecaj položaja imenske skupine i duljine odnosne surečenice na preferencije vezivanja u četirima jezicima (engleski, španjolski, francuski, njemački). Izradili su upitnike koje su ispunjavali izvorni govornici svakoga od tih jezika. U tri su eksperimenta ispitivali tumačenje kratkih naspram dugih odnosnih rečenica, ali i preferencije vezivanja u uvjetima u kojima su se imenske skupine pojavljivale u objektnom ili subjektnom položaju. ${ }^{30} \mathrm{U}$ svim je jezicima preferencija vezivanja ovisila o duljini rečenice (preferencije

\footnotetext{
${ }^{30}$ Primjer kratke (a) i duge (b) rečenice s imenskom skupinom u (1) objektnom i (2) subjektnom položaju: (1.a) The doctor met the son of the colonel who died. (Liječnik je upoznao sina ood pukovnika koji je preminuo.)
} 
prema prvoj imenici u uvjetu dulje rečenice). Nadalje, u svim je jezicima osim u francuskome primijećena češća pojava preferencija vezivanja na prvu imenicu ako je imenska skupina bila u objektnom položaju. Autori smatraju da je tomu tako jer objektni položaj dovodi do prominentnosti prve imenice, $\mathrm{tj}$. do promjene fokusa i preusmjeravanja pažnje govornika. Ovaj je efekt bio veći u njemačkome i španjolskome nego u engleskome jeziku. Preferencije vezivanja na prvu imenicu, neovisno o ispitanom uvjetu, bile su značajno veće u njemačkome i francuskome nego u preostalim ispitanim jezicima. Položaj imenske skupine u nekim se istraživanjima pak nije pokazao značajnim (primjerice, Clifton, 1988; prema Frazier, 1990). Neovisno o polazišnom teorijskom okviru i proturječnim spoznajama o utjecaju navedenih obilježja na obradu, njih je ipak važno kontrolirati budući da mogu utjecati na rezultate u studijama preferencija vezivanja (Hemforth i sur., 2015).

6.2.3. Obilježja imenica unutar imenske skupine (konkretnost i živost)

Preferencije vezivanja variraju i u ovisnosti o obilježjima imenica u strukturama koje se ispituju. Primjerice, Clifton (1988; prema Frazier, 1990) je u istraživanju pokazao da preferencije vezivanja na drugu imenicu u engleskome variraju čak od 25-67\% te da će to u najvećoj mjeri ovisiti o leksičkim osobitostima i značenjskim odnosima imenica. Najmanja je pojavnost vezivanja na drugu imenicu pronađena u rečenicama u kojima je druga imenica imala obilježje neživo. Najsnažnija preferencija vezivanja na posljednju imenicu pronađena je u podražajima u kojima su obje imenice imale jednako obilježje (živo ili neživo). Efekt živosti se tako pokazao vrlo snažnim prediktorom sintaktičke obrade i preferencija vezivanja.

Desmet i sur. (2006) nizom su eksperimenata u nizozemskome također ispitali utjecaj leksičkih obilježja (konkretnosti i živosti) imenica unutar NP, na preferencije vezivanja izvornih govornika. Proučavali su čestotnost pojedinih struktura u korpusu, a spoznaje upotpunili istraživanjima u stvarnom vremenu mjerenjem pokreta očiju izvornih govornika prilikom čitanja odnosnih rečenica. Korpusni su podatci pokazali da se odnosna surečenica $\mathrm{u}$ nizozemskome jeziku značajno češće odnosi na prvu imenicu ako ona ima obilježje živo i

(1.b) The doctor met the son of the colonel who tragically died of a stroke. (Liječnik je upoznao sina øod pukovnika koji je tragično preminuo od moždanog udara.)

(2.a) The son of the colonel who died had written five books on tropical diseases. (Sin ood pukovnika koji je preminuo napisao je pet knjiga o tropskim bolestima.)

(2.b) The son of the colonel who tragically died of a stroke had written five books on tropical diseases. (Sin ood pukovnika koji je tragično preminuo od moždanog udara napisao je pet knjiga o tropskim bolestima.) 
konkretno nego ako se radi o imenici s obilježjem neživo i apstraktno. S druge strane, pokazalo se da odnosna surečenica češće modificira drugu imenicu unutar imenske skupine ako prva imenica ima obilježje neživo i apstraktno. ${ }^{31}$ Statističkom je analizom rezultata istraživanja u stvarnom vremenu također ustanovljena značajna interakcija između varijabli živost prve imenice i vezivanje odnosne rečenice. Potvrđena je očita preferencija vezivanja na prvu imenicu kada je ona zadovoljavala kriterij živosti. U slučaju kada su obje imenice unutar imenske skupine zadovoljavale taj kriterij, vezivanje je ovisilo o obilježju konkretnosti. Statistički značajno kraće vrijeme čitanja i manji broj regresivnih pokreta oka pronađeni su u uvjetima u kojima je odnosna surečenica modificirala imenicu s obilježjem živo i konkretno nego u uvjetima u kojima je modificirala onu s obilježjem neživo i apstraktno.

I u istraživanju u turskome jeziku (Kaya, 2012) dobiveni su jaki efekti živosti. Iako to obilježje nije utjecalo na preferencije vezivanja ispitane u stvarnom vremenu (preferencija prema drugoj imenici unutar složene imenske skupine iznosila je stabilnih 60\%), rezultati su pokazali značajno produljeno vrijeme čitanja u uvjetu u kojem je odnosna surečenica modificirala imenicu s obilježjem neživo naspram uvjeta u kojem je modificirala imenicu s obilježjem živo. Ti su efekti pronađeni i na tzv. ranijim mjerama, što je dokazom da se čitatelj vrlo rano oslanja na sve dostupne obavijesti.

Betancort, Carreiras i Sturt (2009) također su dokazali značajan utjecaj obilježja živosti imenica na sintaktičku obradu. Iako u tom istraživanju nisu ispitivali preferencije vezivanja u odnosnim rečenicama, njihove spoznaje svakako vrijedi spomenuti. Vođeni istraživanjima koja opetovano potvrđuju da su objektne odnosne rečenice značajno zahtjevnije za obradu od subjektnih ${ }^{32}$, autori su provjerili utječu li na ove tendencije i neki značenjski čimbenici. U istraživanju su manipulirali obilježjima živosti imenica u dvjema vrstama odnosnih rečenica u španjolskome. Rezultati su potvrdili da su objektne rečenice značajno zahtjevnije za obradu od subjektnih, ali još je važnija spoznaja o utjecaju obilježja živosti na obradu. Naime, posebno su se zahtjevnima pokazale odnosne rečenice u kojima su glavni antecedent $\mathrm{i}$ imenica u umetnutoj surečenici imali jednako obilježje (primjerice, živo-živo), dok su se manje zahtjevnima pokazale odnosne

\footnotetext{
${ }^{31}$ Kao najčešće primjere konkretnih imenica s obilježjem živosti Desmet i sur. (2006) navode osobe i životinje, a kao apstraktne imenice s obilježjem živosti navode organizacije čiji su članovi osobe (klub, organizacija, vlada). ${ }^{32}$ Istraživanja pokazuju da objektne odnosne rečenice u većoj mjeri opterećuju radno pamćenje (primjerice, Gibson, 1998); da se kasnije usvajaju i da su posebno zahtjevne djeci s jezičnim teškoćama (primjerice, Friedmann i Novogrodsky, 2004; Balija i sur., 2012; Balija Mećar i sur., 2016), kao i osobama odrasle životne dobi, unatoč njihovim očuvanim jezičnim i kognitivnim sposobnostima (primjerice, Wingfield i sur., 2006; Matić i Kuvač Kraljević, 2017).
} 
rečenice u kojima su obilježja tih dviju imenica bila različita (primjerice, neživo-živo). ${ }^{33}$ Slične su spoznaje potvrđene i u nizozemskome (Mak, Vonk i Schriefers, 2006) te engleskome jeziku (Traxler i sur., 2005).

Hernández, Bates i Avila (1994) su se, temeljem rezultata istraživanja sintaktičke obrade govornika španjolskoga i engleskoga jezika u okviru kompeticijskoga modela, usmjerili na stupnjevanje ključeva na koje se govornici tih jezika najviše oslanjaju u obradi. U engleskome se najsnažnijim ključem pokazao redoslijed riječi, potom sročnost i živost, dok je u španjolskome poredak bio drugačiji. U tome se jeziku najsnažnijim ključem pokazala sročnost, potom živost, a redoslijed riječi zauzimao je posljednje mjesto. ${ }^{34} \mathrm{U}$ hrvatskome je jeziku u okviru kompeticijskoga modela ispitivanjima u odgođenom vremenu padež utvrđen kao najvaljaniji i najpouzdaniji ključ, a slijede ga ključevi sročnost u rodu i živost. Jezična se obrada, odnosno oslanjanje na jezične obavijesti razvojno mijenja, pri čemu se djeca u većoj mjeri oslanjaju na obilježje živosti, dok se odrasle osobe prvenstveno oslanjaju na morfološke strukturne ključeve (Mimica, 1988; Kuvač Kraljević, 2008). Iako je padež dominantan ključ u obradi, oslanjanje na morfološke obavijesti nedostatno je u dohvaćanju značenja ako je rečenica dvosmislena (Mimica, 1988). Tako se, u nedostatku jednoznačnih morfoloških ključeva, govornici hrvatskoga počinju oslanjati na obilježja poput redoslijeda riječi i živosti (Mimica, Sullivan i Smith, 1994). Ipak, točan način odvijanja automatskih i nesvjesnih procesa sintaktičke obrade, kao i čimbenika koji ju uvjetuju, nije utvrđen.

Prema Fernández (2003), budući da još uvijek nije potpuno jasno u kojoj mjeri konkretnost i živost igraju ulogu u sintaktičkoj obradi (posebice u različitim jezicima), nedostatno kontroliranje tih leksičkih obilježja može nepovoljno utjecati na oblikovanje spoznaja. Autorica poziva na nova istraživanja kojima će se dodatno ispitati utjecaj leksičkih i strukturnoznačenjskih obilježja na sintaktičku obradu, preferencije vezivanja i tumačenje rečenica. Betancort i sur. (2009) također naglašavaju važnost provođenja istraživanja obrade odnosnih rečenica u različitim jezicima s obzirom na moguće čimbenike koji ju uvjetuju. Naglašavaju da ćemo tek tada biti korak bliže stjecanju valjane slike o složenom fenomenu sintaktičke obrade.

33 Conocían al atleta que venció finalmente al corredor el año pasado naspram Conocían al enfermedad que venció finalmente al corredor el año pasado (hrv. Znali su za atletičara kojega je napokon prošle godine pobijedio trkač naspram Znali su za bolest koju je napokon prošle godine pobijedio trkač).

${ }^{34} \mathrm{U}$ ovakvim se ispitivanjima osobama čitaju rečenice u kojima se variraju redoslijed riječi, živost i druga relevantna obilježja, nakon čega sudionici određuju vršitelja radnje. Ispitivač potom analizira u kojem uvjetu govornik jednostavnije donosi odluku. Takva se ispitivanja provode i u stvarnom vremenu, mjerenjem vremena reakcije tijekom čitanja, tj. mjerenjem brzine kojom sudionici dolaze do konačnoga odgovora u svakom od uvjeta. 


\subsubsection{Vrsta i obilježja relativizatora}

Hemforth i sur. (1998; 2000a; 2000b) razlike u preferencijama vezivanja među govornicima različitih jezika objašnjavaju obilježjima i vrstom relativizatora, tj. različitim mogućnostima uvođenja odnosne surečenice. Drugim riječima, smatraju da će strategije vezivanja odnosne surečenice ovisiti ponajviše o relativizatoru koji joj prethodi, njegovu anaforičkom statusu te osjetljivosti pojedinoga jezika na morfološke i anaforičke obavijesti sadržane u njemu (Hemforth i sur., 1998; 2000a; 2000b; Papadopoulou, 2006). U jezicima poput engleskoga uporaba odnosne zamjenice često je uvjetovana obilježjem živosti njezina antecedenta (who za živo; which za neživo), ali se može zamijeniti i neobilježenim relativizatorom neodređena statusa (that) ili pak potpuno izostaviti (Van Valin, 2001). Upravo zbog različitih mogućnosti i nedosljednosti u uporabi relativizatora govornici engleskoga imaju smanjenu osjetljivost na anaforičke obavijesti i procese uključene u uvođenje i vezivanje odnosne surečenice. Posljedično se oni u većoj mjeri oslanjaju na ostala strukturna obilježja koja su manje zahtjevna za jezičnu obradu.

Govornici jezika u kojima tvorba odnosnih rečenica implicira uporabu morfološki obilježenih odnosnih zamjenica (nastavci za rod, broj, padež) mnogo su osjetljiviji na anaforičke obavijesti u zamjenici. U takvim jezicima postoji veća preferencija vezivanja na prvu imenicu unutar NP jer je ona istaknutiji referent na koji zamjenica upućuje. Prema nekima upravo status referenta uvelike utječe na razrješavanje anaforičkih izraza (Grosz, Joshi i Weinstein, 1995; Hemforth i sur., 1998; 2000a; Papadopoulou, 2006). Istraživanjima preferencija vezivanja u njemačkome, engleskome i švedskome jeziku ove su pretpostavke potvrđene, međutim rezultati sličnih istraživanja $\mathrm{u}$ jezicima poput rumunjskoga, španjolskoga i hrvatskoga osporili su ih. U rumunjskome je jeziku istraživanjem u odgođenom vremenu pronađena preferencija vezivanja na bližu imenicu (58\%), iako i ovaj jezik podrazumijeva uporabu morfološki obilježene odnosne zamjenice (Ehrlich, 1999). Hrvatski jezik pak dozvoljava uporabu morfološki obilježene odnosne zamjenice (koji/a/e), kao i neodređenog relativizatora (veznička riječ što). U hrvatskome bi jeziku tumačenje odnosnih rečenica stoga također trebalo ovisiti o obilježjima relativizatora kojim je uvedena odnosna surečenica. Lovrić i Fodor (2000) proveli su ispitivanja u odgođenom vremenu u kojima su manipulirali upravo ovim obilježjem (uvođenje odnosne surečenice zamjenicom koji naspram vezničkom riječju što). Pronađena je preferencija prema prvoj imenici neovisno o statusu i obilježju relativizatora (koji: 61\% i što: 57\%). Budući da su rezultati kontradiktorni i nedosljedni, za jasnije bi se spoznaje o utjecaju vrste relativizatora na sintaktičku obradu trebala provesti nova, pomno kontrolirana istraživanja u različitim jezicima. 
Iako ne treba odbaciti važnost različitoga stupnja osjetljivosti jezika na izražavanje anaforičkih odnosa ili utjecaj morfološkoga označavanja relativizatora kojim se uvodi odnosna rečenica na njezino konačno tumačenje, složeni se utjecaj značenjskih odnosa na sintaktičku obradu ipak ne može objasniti isključivo time.

\subsubsection{Sadržaj odnosne surečenice}

Psiholingvističke studije sintaktičke obrade impliciraju provedbu eksperimenata s preciznom kontrolom i manipulacijom sadržajima koji se ispituju. Upravo je metodologija u pozadini psiholingvističkih eksperimenata otvorila dodatna pitanja i potvrdila značajan utjecaj sadržaja ispitanih struktura na sintaktičku obradu. Primjerice, istraživanja u stvarnom vremenu (metoda čitanja vlastitom brzinom ili metoda praćenja pokreta očiju) ne podrazumijevaju ispitivanje tumačenja isključivo dvosmislenih odnosnih rečenica, što je čest slučaj s ispitivanjima metodom upitnika. Takve suvremene metode naime podrazumijevaju ispitivanje obrade odnosnih rečenica u kojima se eksperimentalno manipulira načinom na koji se dvosmislenost razrješava, modifikacijom prve ili druge imenice, kao i mjestom na kojem će ključna obavijest čitatelju biti dostupna. Jedino se na taj način mogu uspoređivati bihevioralni odgovori sudionika istraživanja u dvama uvjetima - onome u kojem se dvosmislenost razrješava tako da se odnosna surečenica strukturno ili značenjski može odnositi isključivo na prvu, odnosno isključivo na drugu imenicu u imenskoj skupini.

Općenito postoje dvije mogućnosti eksperimentalne manipulacije sadržajem odnosne surečenice i mjestom na kojem će modifikacija postati jasna i nedvosmislena, a to su manipuliranje morfološkim obilježjima (sročnost u rodu/broju) i manipuliranje značenjskom prihvatljivošću s obzirom na enciklopedijsko znanje (Fernández, 2003). Valja pobliže razjasniti što takve manipulacije podrazumijevaju.

Eksperimentom kojim se žele ispitati preferencije vezivanja na prvu ili drugu imenicu nastoji se provjeriti u kojem će od tih dvaju uvjeta čitanje biti otežano - u uvjetu u kojem se odnosna surečenica odnosi na prvu imenicu ili u uvjetu u kojem se ona odnosi na drugu imenicu. Ako se manipulira sročnošću u rodu, tada će jedna od dviju imenica unutar NP biti u muškom, a druga u ženskom rodu, a odnosna će se surečenica vezivati samo na jednu od njih. Drugim riječima, zbog poštivanja sročnosti odnosna se surečenica mora odnositi ili na imenicu u 
muškom, ili na imenicu u ženskom rodu. ${ }^{35}$ Jednako tako, ako se želi manipulirati sročnošću u broju, jedna će od dviju imenica biti u jednini, a druga u množini. Ponovno, zbog poštivanja sročnosti, odnosna će se surečenica morati odnositi samo na jednu od dviju imenica s obzirom na obilježje broja - onu u jednini ili onu u množini. Manipuliranje morfološkim obilježjima i sročnošću ujedno je i najčešći način razrješavanja početne dvosmislenosti u istraživanjima sintaktičke obrade. Tomu je tako jer omogućava jednostavnu i preciznu eksperimentalnu manipulaciju.

Ako se pak manipulira značenjskom prihvatljivošću, obje će imenice najčešće dijeliti isto obilježje roda i broja. Tada će se tek značenjskim obilježjima odnosne surečenice koja slijedi nakon zamjenice nagovijestiti odnosi li se ona na prvu ili na drugu imenicu. Budući da su značenjske obavijesti uvjetovane kulturom i iskustvom, ovakav se način manipulacije podražajima najčešće izbjegava u istraživanjima u kojima se izravno uspoređuje više jezika. ${ }^{36}$ Značenjska obavijest kojom se u eksperimentima ipak može manipulirati jest, primjerice, obilježje živosti. Već je ranije spomenuto da leksička obilježja imenica (a ponajviše upravo živost) mogu utjecati na način na koji se rečenica tumači. Primjerice, ako jedna od dviju imenica u složenoj imenskoj skupini ima obilježje neživo, a druga živo, značenjem se rečenice može manipulirati na način da se odnosna surečenica koja slijedi odnosi ili na neživo ili na živo. U analizi se zatim promatra koji je uvjet sudioniku istraživanja, izvornomu govorniku jezika, prilikom čitanja bio zahtjevniji za obradu. Na važnost kontrole načina na koji se u eksperimentu razrješava dvosmislenost uputile su pojedinačne studije, ali i meta-analize već provedenih studija potaknute nedosljednostima u spoznajama (Fernández, 2003; Papadopoulou, 2006).

Potvrđeno je da upravo način na koji je ostvaren eksperimentalan uvjet vezivanja na prvu ili drugu imenicu može utjecati na rezultate (s razlikama vidljivima u vremenskoj komponenti obrade i konačnim preferencijama sudionika). Razlike su u istraživanjima pronađene kada se manipuliralo sročnošću naspram značenjskom prihvatljivošću, ali i kada se manipuliralo sročnošću u rodu naspram sročnošću u broju. Carreiras, Betancort i Meseguer (2001) u svome su istraživanju pokazali da govornici španjolskoga imaju preferencije prema prvoj imenici kada se u rečenicama manipulira sročnošću u rodu, a preferencije prema drugoj kada se manipulira sročnošću u broju. Fernández i Sainz (2004) čak su dvjema metodama ispitali razlike u sintaktičkoj obradi ovisno o načinu razrješavanja dvosmislenosti. Rezultati su ponovno

\footnotetext{
${ }^{35}$ Dakako, u nekim se jezicima ova obavijest nalazi već i u morfološki obilježenoj odnosnoj zamjenici.

${ }^{36}$ Iako bi to bilo zanimljivo i dalo i puno šire uvide, otežalo bi donošenje jednoznačnih zaključaka u okviru najčešće ispitivanih modela.
} 
pokazali da preferencija vezivanja govornika španjolskoga značajno ovisi o manipulaciji sročnošću (u broju) i značenjem. Autori naglašavaju da su različite i nesustavne spoznaje posljedica nedovoljno kontroliranih eksperimenata. Pozivaju na provedbu istraživanja $\mathrm{s}$ pomnijom kontrolom tih počesto zanemarenih čimbenika, kako bi se moglo ustanoviti koje je obilježje (tj., ključ) relevantnije i snažnije u kojem jeziku te što primarno vodi sintaktičku obradu. U suprotnome se, zbog neujednačenih i nepreciznih eksperimenata, otežava donošenje valjanih zaključaka o jezičnoj obradi općenito, ali i u pojedinačnim jezicima.

Iako je manipulacija značenjskom prihvatljivošću rjeđa od manipulacije sročnošću, eksperimentalna se manipulacija u mnogim istraživanjima temelji upravo na enciklopedijskome znanju. Jedno je takvo istraživanje ono Cuetosa i Mitchella (1988). Primjer rečenice u kojoj je ostvaren eksperimentalan uvjet vezivanja na prvu imenicu jest

(9) španj. Alguien disparó contra la criada del actor que estaba en el balcón con su marido.

[ hrv. Netko je ubio sluškinju øod glumca koja je bila na balkonu sa svojim suprugom. ]. ${ }^{37}$

Takvom je manipulacijom značenjem ostvarena nužnost vezivanja na prvu imenicu jer su rodne uloge pod utjecajem enciklopedijskoga znanja (vjerojatnije je da je sluškinja ta koja ima supruga, a ne glumac). Carreiras i Clifton (1999) također su se u eksperimentalnoj kontroli usmjerili na manipulaciju uvjetovanu enciklopedijskim znanjem, tj. rodnim ulogama. Takva je manipulacija u spomenutim istraživanjima ipak upitna budući da su u njima sudjelovali govornici dvaju jezika, a time i pripadnici dviju različitih kultura. Kako su rečenice samo prevedene iz jezika u jezik, vjerodostojnost se rezultata može dovesti u pitanje (Fernández, 2003; Papadopoulou, 2006). U istraživanjima usmjerenima na izravnu usporedbu sintaktičke obrade u različitim jezicima posebna se pažnja treba posvetiti izradi usporedivih materijala. Ako se dvosmislenost $u$ ispitnim rečenicama razrješava sročnošću, obavijest o tome mora biti dostupna na istom mjestu u rečenici u obama jezicima, a ako se pak razrješava značenjskom prihvatljivošću, mora se pripaziti na prethodno iskustvo i kulturu govornika tih jezika. Kako ovo doktorsko istraživanje sintaktičke obrade nije usmjereno na izravnu usporedbu hrvatskoga i nekoga drugog jezika, za detaljan opis problematike istraživanja u dvama jezicima vidi Fernández (2003).

\footnotetext{
${ }^{37} \mathrm{U}$ hrvatskome dvosmislenosti nema jer je obavijest o rodu dostupna već u odnosnoj zamjenici (koja, naspram španj. zamjenice que, koja ne nosi obilježje roda).
} 
Papadopoulou (2006) naglašava da oprečni rezultati eksperimenata s različitim načinima ostvarivanja modifikacije i razrješavanja početne dvosmislenosti svakako imaju zanimljive implikacije na utjecaj morfoloških i značenjskih obavijesti (ključeva) na sintaktičku obradu u različitim jezicima. Ipak, to zahtijeva dodatnu provjeru ili barem pomnu eksperimentalnu kontrolu te oprez prilikom smišljanja podražaja i interpretacije rezultata.

Upravo je stoga prilikom smišljanja podražaja za eksperimente u ovom doktorskom istraživanju posebna pažnja posvećena načinu razrješavanja dvosmislenosti, tj. načinima eksperimentalne modifikacije. U jednom se eksperimentu vezivanje ostvaruje sročnošću u rodu, a u drugome značenjskom prihvatljivošću s obzirom na obilježje živosti. Pritom valjanost podražaja nije upitna jer njihovo tumačenje ne ovisi o kulturološkoj pozadini ili osobnim stavovima. Radi dodatne potvrde ove tvrdnje, neovisni su sudionici prethodno ocijenili valjanost materijala. Način izrade podražaja detaljno je opisan u poglavlju 10.1. Razvoj ispitnih podražaja. 


\section{NAČINI ISPITIVANJA PREFERENCIJA VEZIVANJA}

U ovom poglavlju dajemo osvrt na metodologiju i načine ispitivanja preferencija vezivanja, iznoseći prednosti i nedostatke pojedinih metoda, kao i važnost njihova kombiniranja.

\subsection{Metode u odgođenom vremenu}

Preferencije vezivanja u izoliranim odnosnim rečenicama najčešće se ispituju metodama u odgođenom i u stvarnom vremenu (izv. eng. offline i online). Iako metode u odgođenom vremenu ne pružaju uvid u inkrementalne procese tijekom sintaktičke obrade, to jest u njezin vremenski tijek, tako se provedenim eksperimentima može ispitati konačno tumačenje rečenica (Love i Swinney, 1998). Prednosti uporabe metoda u odgođenom vremenu jesu ekonomičnost i jednostavnost u samoj primjeni, kao i u analizi rezultata (Schmitt i Miller, 2010; vidi i Matić, 2017).

Ispitivanja preferencija vezivanja u odgođenom vremenu podrazumijevaju primjenu upitnika sa zadatcima prosudbe (izv. eng. judgement task) u kojima se najčešće nakon prikazane dvosmislene rečenice postavljaju pitanja prisilnog odabira (izv. eng. forced-choice task; Mendelhson i Pearlmutter, 1999; Fernández, 2003; Kaya, 2012) ili pak upitnika sa zadatcima dovršavanja rečenica (izv. eng. completion task; McRae i sur., 1998; Thornton i sur., 1998; Desmet i sur., 2002; Papadopoulou, 2006). Oba načina ispitivanja u odgođenom vremenu metodom papir-olovka imaju svoje prednosti i nedostatke. Prednost je upitnika s unaprijed ponuđenim odgovorima bolja mogućnost kontrole načina na koji sudionici odgovaraju te jednostavnija analiza odgovora, a nedostatak je veći rizik da će odgovarati nasumično, posebice ako je pitanja mnogo. Nedostatak im je i sužavanje raspona mogućih odgovora čime se ipak ograničava uvid u spoznaje o problematici koja se istražuje. Prednost je zadatka dovršavanja rečenica veća razina aktivnoga sudjelovanja osoba jer im se odgovori ne sugeriraju unaprijed, a nedostatak je manja mogućnost kontrole načina na koji pojedinci odgovaraju, a što može rezultirati većim brojem neispravnih odgovora te njihovom zahtjevnijom analizom i interpretacijom.

Ispitivanjima u odgođenom vremenu stječe se dakle uvid u konačno tumačenje rečenica $\mathrm{i}$ konačne preferencije sudionika, što može olakšati oblikovanje pretpostavki o automatskim procesima sintaktičke obrade u stvarnom vremenu. 


\subsection{Metode u stvarnom vremenu}

Metode u stvarnom vremenu omogućuju stjecanje uvida u vremenski tijek obrade, odnosno u automatske procese sintaktičke obrade. Iako se njihovom uporabom značajno usložnjava provedba samoga eksperimenta i kasnija analiza rezultata, premošćuju se gotovo svi nedostatci metoda u odgođenom vremenu, poput nemogućnosti mjerenja sudionikova nesvjesnoga odgovora na jezični podražaj (Marinis, 2010). U kontekstu istraživanja relevantnih za ovu disertaciju koja je usmjerena na ispitivanje preferencija vezivanja u odnosnim rečenicama, opisat će se metode koje se najčešće primjenjuju: metoda čitanja vlastitom brzinom (izv. eng. self-paced reading) i metoda praćenja pokreta očiju (izv. eng. eye-tracking). Obje u većoj ili manjoj mjeri podrazumijevaju i mjerenje vremena reakcije (izv. eng. reaction time). ${ }^{38}$

\subsubsection{Metoda čitanja vlastitom brzinom}

Metoda koja primjenjuje paradigmu čitanja vlastitom brzinom u psiholingvistici se pojavila 70ih godina 20. stoljeća kao posljedica težnje kognitivnih psihologa za mjerenjem jezičnoga razumijevanja u stvarnom vremenu (Jegerski, 2014). Metoda je jednostavna jer se podražaj (najčešće riječ ili veći dio rečenice) prikazuje na zaslonu računala, pri čemu osoba samostalno pritiskom tipke kontrolira kada će se pojaviti idući podražaj, odnosno sljedeća riječ ili dio rečenice. Svaki je sljedeći podražaj dakle maskiran, tj. skriven dok osoba ne dovrši čitanje onoga dijela koji joj je dostupan na zaslonu. Logička je pozadina ove metode pretpostavka da odgođeno vrijeme pritiska tipke podrazumijeva dulje vrijeme čitanja uslijed teškoća jezične obrade (Just, Carpenter i Woolley, 1982). Prednosti su metode njezina jednostavnost i široka mogućnost primjene, čak i izvan strogo laboratorijskih uvjeta (Clahsen, 2008). Unatoč lakoj primjenjivosti i ekonomičnosti glavni joj je nedostatak manjak prirodnosti u procesu čitanja. Naime, ljudi ne čitaju riječ po riječ, već pogledom zahvaćaju i okolne obavijesti. Preskaču redundantne ili kratke riječi, dok se na one dulje, zahtjevnije, manje učestale ili neočekivane ponovno vraćaju (Rayner, 2009). Osim toga, stalna potreba za pritiskanjem tipke tijekom izvođenja zadataka ometajući je čimbenik u procesu, zbog čega se ovom metodom donekle usporava proces čitanja i pružanja odgovora u odnosu na neke druge metode (Carreiras i Clifton, 2004; Clahsen, 2008; Jegerski, 2014).

\footnotetext{
${ }^{38}$ Ostale metode poput metoda oslikavanja mozga nisu prikladne za ovakve studije. Njihova su obilježja opisana u Carreiras i Clifton (2004) ili Sekerina, Fernández i Clahsen (2008).
} 
Unatoč tim nedostatcima upravo je metoda čitanja vlastitom brzinom riječ-po-riječ ili frazapo-fraza jedna od najčešćih u ispitivanjima preferencija vezivanja (Felser i sur., 2003; Fernández, 2003; Omaki, 2005; Papadopoulou, 2006; Swets i sur., 2008). Ključna metodološka odluka koja može utjecati na rezultate istraživanja jest način segmentacije i prikazivanja podražaja. Naime, određivanje mjesta u rečenici na kojem će se fraza umjetno prekinuti, a od osobe zatražiti pritisak tipke može sugerirati prozodijsku segmentaciju i utjecati na način na koji će ona čitati u sebi. Iz toga razloga način prikazivanja podražaja može neizravno utjecati na sintaktičku obradu i preferencije sudionika istraživanja (Fernández, 2003). Primjerice, ako se izolirana odnosna rečenica prikaže na način da se prva i druga imenica unutar NP umjetno razdvoje, to može uzrokovati preferencije vezivanja na drugu imenicu. Istovremeno prikazivanje obiju imenica pak može uzrokovati preferencije vezivanja na prvu. Ako su ovakvi i slični ishodi uvjetovani metodološkim odlukama prilikom planiranja istraživanja, i rezultati se mogu pogrešno interpretirati. Upravo su zbog načina segmentacije i prikazivanja podražaja opravdano u pitanje dovedena istraživanja poput onih De Vincenzi i Joba (1993) kojim je u talijanskome pronađena preferencija prema drugoj imenici, te Cuetosa i Mitchella (1988) kojim je u španjolskome ustanovljena snažna preferencija prema prvoj. Optimalnim se načinom prikazivanja podražaja u studijama preferencija vezivanja stoga smatra istovremeno prikazivanje čitave rečenice na zaslonu (Mitchell i Brysbaert, 1998). Na taj se način izbjegava sugeriranje prozodijske segmentacije, osigurava prirodnost u čitanju te, konačno, ostavlja mogućnost vraćanja na prethodno pročitane dijelove rečenice (Rayner, 1998; Carreiras i Clifton, 1999; 2004).

\subsubsection{Metoda praćenja pokreta očiju}

Metoda praćenja pokreta očiju pruža više informacija i mogućnosti analize od prethodno opisanih metoda jer se tijekom čitanja automatski mjere i bilježe podatci o pokretima očiju, čak i prije završetka čitanja prikazane rečenice. Bitna prednost ove metode nad ostalima jest i to što se njezinom uporabom pojedincu onemogućava inhibiranje nedoumica tijekom obrade pa sve strategije njegova odlučivanja odmah postaju razvidne (Sedivy, 2010). Ranije spomenuta inkrementalnost sugerira da se značenje rečenice gradi riječ po riječ, a praćenje pokreta očiju omogućava uvid upravo u tijek tih procesa - mjerenjem duljine zadržavanja na pojedinoj riječi, bilježenjem broja pokreta očiju u suprotnom smjeru ili brzine kojom čitatelj prelazi preko teksta. Nadalje, metoda omogućava i uvid u to je li došlo do neuspjeha u interpretaciji zadatka 
ili do preopterećenosti sustava jezične obrade, a pogodna je za ispitivanje ljudi svih životnih dobi i neinvazivna je (Rayner, 1998; Carreiras i Clifton, 2004; Sedivy, 2010; Matić, 2017).

Logička se pozadina ove metode temelji na činjenici da pokreti očiju izravno osvjetljavaju kognitivne procese u pozadini. Just i Carpenter (1980) ta su razmatranja objedinile u dvjema pretpostavkama. Prva je pretpostavka neposrednosti (izv. eng. immediacy assumption) prema kojoj je riječ glavna jedinica obrade, a čitatelj obrađuje upravo onu riječ koju trenutno fiksira pogledom. Druga je pretpostavka oko-um (izv. eng. eye-mind assumption) prema kojoj postoji izravna veza između onoga u što osoba gleda i na što misli, tj. što u umu obrađuje, čime se fiziološka razina kontrole pokreta oka povezuje s kognitivnim procesima koji su u pozadini.

Prilikom čitanja ili promatranja određenoga prizora oči se ne kreću u pravilnim razmacima, već čine malene skokovite pokrete koji se zovu sakade. Ti su pokreti balistički, tj. ne mijenjaju svoj smjer i domet nakon što su započeti. Čitanje odlikuju približno tri ili četiri sakade u sekundi, a njihova duljina ovisi o brojnim čimbenicima, kako razvojnima tako i jezičnima. U čitanju naglas sakada obuhvaća šest grafema (Rayner, 1998), a čitatelj preskače otprilike $25 \%$ riječi u tekstu. Preskakanje dijelova rečenice ovisit će o duljini i čestotnosti riječi te njezinoj predvidljivosti s obzirom na kontekst (Rayner, 2009; Palmović i sur., u tisku). Čak 90\% čitanja čine fiksacije, odnosno vrijeme u kojem su pokreti oka donekle stabilni. Oči prilikom čitanja ostaju fiksirane oko 250 ms (Rayner, 2009), a smatra se da čitatelj u pravilu ne može izdvojiti mnogo obavijesti ako fiksacija traje kraće od 80 ms (Rayner i Pollatsek, 1989). Nakon fiksacije mogu uslijediti dva pokreta - sakada u smjeru čitanja ili sakada u suprotnome smjeru, regresija. Do regresije ili povratka na prethodno fiksirano područje dolazi zbog nepotpunog razumijevanja prethodnoga sadržaja, odnosno zbog poteškoća u obradi, i one čine otprilike 15\% svih pokreta očiju (Rayner, 1998; 2009). Još je od početka 20. stoljeća poznato da se ova obilježja razvojno mijenjaju: trajanje i ukupan broj fiksacija, kao i učestalost regresija postupno se smanjuju, dok duljina ili domet sakada raste (Buswell, 1922). Obrazac pokreta očiju tijekom čitanja drugačiji je u osoba s jezičnim teškoćama - više je nalik djeci niže kronološke dobi (Rayner, 1998; Matić, Coumel i Palmović, 2018). Spoznaje nalik ovima dodatna su potvrda da pokreti oka izravno ocrtavaju procese jezične obrade.

Obrada riječi ne završava u trenutku kad oko napusti riječ, odnosno kad nastupi sljedeća sakada, već dolazi do takozvanoga učinka prelijevanja (izv. eng. spill-over effect; Schroyens i sur., 1999). On se odnosi na činjenicu da složenost riječi $n$ utječe na trajanje fiksacije na riječi $n+1$. Naime, što je riječ $n$ složenija za obradu, manje vremena preostaje za obradu riječi $n+1$, stoga se složenost riječi $n$ prelijeva, a trajanje se fiksacije na sljedećoj riječi produljuje (Pollatsek, 
Reichle i Rayner, 2006). Dokazano je da, primjerice, čestotnost fiksirane riječi utječe na obradu sljedeće, a što se očituje produljenjem fiksacije na toj idućoj riječi (Rayner i Duffy, 1986). Upravo je iz toga razloga $\mathrm{u}$ istraživanjima sintaktičke obrade posredstvom čitanja potrebno kontrolirati obilježja riječi koja mogu utjecati na način na koji oko prelazi preko teksta i tako maskirati utjecaj čimbenika koji se doista žele eksperimentalno ispitati. Nadalje, učinak prelijevanja upućuje na nužnost uzimanja u obzir i mjera koje se odnose na dijelove rečenice koji slijede nakon ciljanih dijelova koji se ispituju. Naime, teškoće u obradi ponekad se mogu manifestirati sa stupnjem odgode. U mnogim je istraživanjima primijećena još jedna pojava, takozvani učinak završavanja (izv. eng. wrap-up effect). On podrazumijeva da čitatelj više vremena provodi čitajući posljednje riječi u rečenici nego čitajući riječi u središnjem dijelu, do čega dolazi uslijed krajnje unutar- i međurečenične integracije (Just i Carpenter, 1980). Zbog te je pojave nužno osigurati da se ciljane obavijesti (primjerice, dijelovi rečenice koji se ispituju i kojima se manipulira) nalaze otprilike u središnjem dijelu rečenice. Da se nalaze na kraju, dulje bi čitanje i produljenje trajanja fiksacija moglo biti i posljedica opisanoga fenomena, a ne nužno teškoća obrade.

Unatoč velikom broju dostupnih podataka, kao što su oni o vremenu zadržavanja na određenoj riječi ili broju vraćanja na prethodnu, još uvijek nije dovoljno razjašnjeno koje su mjere pokreta očiju najosjetljivije i samim time najpogodnije za istraživanje pojedinih jezičnih fenomena (Sedivy, 2010). Danas su općeprihvaćene tvrdnje da su procesi u pozadini obrade pojedinačne riječi i njezine inkrementalne integracije u rečenični kontekst vidljivi u ranim mjerama poput trajanja prve fiksacije, a procesi sintaktičke obrade na globalnoj razini u kasnijim mjerama poput ukupnoga trajanja svih fiksacija (Reichle i sur., 1998). Pokreti oka na taj način odražavaju interakciju strukturnih $\mathrm{i}$ značenjskih procesa u pozadini obrade na leksičkoj razini (prepoznavanje pojedinačnih riječi i njihova integracija u jezični kontekst), kao i naknadnih procesa obrade na sintaktičkoj razini (Deutsch i Bentin, 2001). Upravo stoga kombinirane mjere ranijih i kasnijih procesa mogu pružiti različite obavijesti o kognitivnim procesima koji se odvijaju tijekom čitanja, odnosno u pozadini su sintaktičke obrade i jezičnoga razumijevanja. Nedostatak je ove metode u kontekstu istraživanja preferencija vezivanja to što se ispitivanje neizbježno ograničava isključivo na kratke rečenice jer podražaji moraju biti prikazani u jednome retku (Fernández, 2003). To je nužno kako bi se osigurala linearnost u čitanju i spriječilo upućivanje pogleda u svim smjerovima što bi značajno otežalo analizu i interpretaciju rezultata. Konkretne mjere pokreta oka koje će se analizirati u ovome radu bit će objašnjene u poglavlju o metodologiji. 


\subsection{Važnost kombiniranja metoda}

Na kraju ovoga poglavlja svakako valja istaknuti važnost provođenja oba načina ispitivanja, u odgođenom i u stvarnom vremenu. Kako je već spomenuto, ispitivanjima u odgođenom vremenu (upitnicima) stječe se uvid u konačne preferencije sudionika, čime se može započeti s oblikovanjem pretpostavki o automatskim procesima sintaktičke obrade u stvarnom vremenu. Upitnici su stoga vrlo česta metoda u sličnim istraživanjima (Cuetos i Mitchell, 1988; Frazier i Clifton, 1996; Fernández, 2003; Lovrić, 2003; Papadopoulou, 2006), ali ove će inicijalne sklonosti u interpretaciji govornikovih preferencija za istraživača dodatno dobiti na vjerodostojnosti i pouzdanosti ako ih se kombinira sa spoznajama iz istraživanja u stvarnom vremenu.

Mitchell i sur. (1995) među prvima su kritizirali istraživanja u kojima se spoznaje o preferencijama temelje samo na jednoj metodi, posebice onoj u odgođenom vremenu, jer ona ne pruža informacije o najranijim fazama jezične obrade. Kako bi studije doista bile valjane, potrebno je kombinirati obje metode (Fernández, 2003; Papadopoulou, 2006; Kaya, 2012; Payne i sur., 2014; Hemforth i sur. 2015). Pritom valja osigurati visoku razinu eksperimentalne kontrole i međusobnu usporedivost ispitnih podražaja u objema metodama. Kontrola i ujednačenost rečenica za posljedicu može imati upoznatost sudionika s nacrtom, zbog čega i njihovo čitanje može biti površno. Veliki broj umetnutih podražaja i nasumično prikazivanje rečenica mogu umanjiti ove neželjene posljedice (Clahsen, 2008).

Osiguravanje raznolikosti eksperimentalnih metoda smatra se važnijim i od inzistiranja na velikome broju ispitnih podražaja, posebice ako su zbog toga oni upitne kvalitete, tj. lingvističke ispravnosti (Baayen, 2014). Iako je uporaba složenih eksperimentalnih metoda vrijedna, važnije je iste povezati s jezičnom teorijom i jednom pitanju pristupiti na nekoliko različitih načina (Mertins, 2016). U konačnici, kombiniranje je eksperimentalnih pristupa utoliko vrjednije ako sve, ili barem većina upotrijebljenih metoda, rezultiraju donekle istovjetnim spoznajama. Tako se povećava mogućnost postojanja jedinstvenog objašnjenja fenomena koji se istražuje, što rezultatima daje na snazi. 


\section{ISTRAŽIVANJA PREFERENCIJA VEZIVANJA U HRVATSKOME}

Sintaktička obrada i preferencije vezivanja u hrvatskome su jeziku dosad ispitane u okviru hipoteze implicitne prozodije. Lovrić i njegovi suradnici rezultatima su nekoliko eksperimenata pokazali da je sintaktička obrada u pojedinome jeziku uvjetovana načinima prozodijske segmentacije izraza svojstvenima tome jeziku, a koje govornik implicitno uči, neovisno o strukturnim i značenjskim čimbenicima u rečenici (Lovrić i Fodor, 2000; Lovrić, Bradley i Fodor, 2000; Lovrić, 2003). Lovrić i sur. (2000) ispitali su postoje li razlike u preferencijama ako relativizatoru prethode besprijedložne genitivne dopune i ako mu prethode genitivne dopune s prijedlogom od. ${ }^{39}$ Rezultati su pokazali jasne preferencije vezivanja na prvu imenicu koje su ipak bile manje kada je relativizatoru prethodila prijedložna imenska skupina (od + genitiv) (vidi i Lovrić, 2003). Osim upitnika u odgođenom vremenu u kojem su sudionici određivali antecedenta dvosmislene odnosne rečenice, $u$ jednome su od eksperimenata naglas čitali rečenice s besprijedložnim i prijedložnim genitivnim dopunama. Akustičke su analize snimki pokazale da prisutnost prijedloga od značajno mijenja prozodijsku segmentaciju rečenice prilikom čitanja, što posljedično utječe na preferencije vezivanja (Lovrić i sur., 2001). ${ }^{40}$ Autori su varirali i duljinu odnosnih rečenica kako bi ispitali utjecaj duljine na preferencije vezivanja. U kratkim odnosnim rečenicama pronađeno je vezivanje na drugu imenicu, dok je u duljim rečenicama većina sudionika iskazala preferencije vezivanja na prvu. Te su spoznaje autori također pripisali razlikama u prozodijskoj segmentaciji rečenica u dvama uvjetima.

Lovrić je, ispitujući preferencije vezivanja u hrvatskome, svakako dao doprinos širenju međujezičnih spoznaja o sintaktičkoj obradi. Ipak, njegovo se teorijsko polazište temeljilo gotovo isključivo na utjecaju prozodijskih obilježja jezika na obradu, zbog čega su i spoznaje donekle ograničene. Takvim istraživanjima nedostaje jasniji uvid u obilježja ispitanih struktura, primjerice $u$ odnose između mogućih antecedenata odnosne rečenice. Ispitni su podražaji bili ograničeni isključivo na jednu vrstu genitivnih dopuna, ponajviše one koji odražavaju odnose posvojnosti, rodbinske ili poslovne odnose. Osim toga, istraživanja su bila usmjerena na

\footnotetext{
${ }^{39}$ Lovrić navodi da su u hrvatskome jeziku obje mogućnosti opravdane; primjerice kćerka od učiteljice i kćerka učiteljice.

${ }^{40}$ Prijedlog od istovjetan je prijedlogu of u engleskome ili de u španjolskome, odnosno ni on nema mogućnost tematskog označavanja druge imenice unutar imenske skupine. Činjenica da unatoč tomu značajno utječe na preferencije vezivanja, tvrdi Lovrić, nije u skladu s teorijama koje sintaktičku obradu objašnjavaju diskursnim, strukturnim ili značenjskim čimbenicima.
} 
manipuliranje načinom prikazivanja podražaja, a time se sudioniku neizbježno sugerira interpretacija rečenice.

Matić i sur. (2019) kombinacijom su mjera u odgođenom i stvarnom vremenu (upitnikom prosudbe i metodom praćenja pokreta očiju) ispitali utjecaj višestrukih mogućnosti slaganja s koordiniranom imenskom skupinom na preferencije vezivanja u odnosnoj rečenici, kao i same strategije sintaktičke obrade tih struktura u hrvatskome. Rezultati upitnika prosudbe odabira antecedenta u odnosnim rečenicama pokazali su da sudionici antecedentom odnosne rečenice u različitim omjerima smatraju čitavu koordiniranu skupinu ili posljednju imenicu koja je dijelom takve skupine. Metodom praćenja pokreta očiju zabilježeno je produljeno vrijeme čitanja dvosmislenih struktura, što je pokazateljem teškoća obrade i kompeticije razina obavijesti uslijed višestrukih mogućnosti interpretacije. Provedena je studija potvrdila potrebu za sustavnim i kontroliranim istraživanjima unutarjezičnih čimbenika koji utječu na obradu. Ipak, nekoliko je nedostataka koje valja premostiti u daljnjim istraživanjima. Prije svega, različite su skupine sudionika ispunjavale upitnik i sudjelovale u istraživanju u stvarnom vremenu, zbog čega se ne može zanemariti mogući utjecaj individualnih razlika na rezultate. Osim toga, varirali su se isključivo strukturni čimbenici, bez uvida u značenjska obilježja. Naposljetku, imenske su skupine bile u odnosu konjunkcije, a ne u genitivnim i prijedložnim dopunama, što je svojevrsni standard $\mathrm{u}$ ispitivanjima preferencija vezivanja kojim se osiguravaju i valjane međujezične usporedbe.

Matić (2018) je u predistraživanju za potrebe izrade istraživačkoga nacrta doktorskoga rada upitnikom prisilnog odabira ispitala preferencije vezivanja u odnosnim rečenicama u kojima se variralo upravo strukturno-značenjskim odnosima imenica u imenskoj skupini. Antecedenti su bili u genitivnim dopunama ili dijelom prijedložno-padežnih izraza $(s, z a, n a)$ baš iz razloga što prema konstrualnoj hipotezi prijedlozi mogu tematski označiti imenicu koja slijedi i tako utjecati na preferencije vezivanja. U istraživanju je sudjelovalo 90 izvornih govornika hrvatskoga u dobi od 20 do 65 godina. Unatoč predviđanjima hipoteze, uz poneku je iznimku potvrđena prevladavajuća preferencija vezivanja na prvu imenicu. U genitivnim je dopunama ta preferencija iznosila 68,9\%, u prijedložno-padežnim izrazima u kojima se prijedlogom $s$ označavalo svojstvo 74,2\%, a jedini uvjet u kojem je pronađena jasna i sustavna preferencija na drugu imenicu (36,1\% odabira prve) bile su rečenice u kojima su imenice bile povezane prijedlogom na. Iznimno je važno naglasiti da su u tim rečenicama nakon prijedloga $n a$ slijedile imenice u akuzativu, a ne lokativu (primjerice, kritika na predstavu koja). Najveća je varijabilnost $u$ odgovorima zabilježena u uvjetima $u$ kojima su imenice bile povezane 
prijedlogom $z a$, nakon kojega je također slijedila imenica u akuzativu (primjerice, zahtjev za razvod koji). Preferencije prema prvoj imenici u tim su rečenicama varirale od 30\% do 78,9\% $(\mathrm{M}=51,7 \%)$.

Iako na temelju sporadičnih istraživanja nije opravdano donositi konačne zaključke, važno je primijetiti da govornici strukturno različitih jezika doista pokazuju različite strategije obrade i različite preferencije vezivanja, tj. različito tumače naizgled slične strukture. Konkretno, rezultati posljednjega navedenog istraživanja upućuju na mogući utjecaj značenjskih čimbenika i odnosa imenica unutar NP, na obradu i tumačenje rečenica i u hrvatskome. Ipak, taj utjecaj nije jednak u svim prijedložnim uvjetima, već i tu postoje razlike, što je još jedan pokazatelj opasnosti snažnih generalizacija. Može se zaključiti da su mehanizmi sintaktičke obrade i način na koji tumačimo određene strukture kudikamo složeniji od jedne jednostavne formule te da brojni čimbenici igraju ulogu u tom složenom procesu, a posebice u morfološki razvijenim jezicima.

Novije spoznaje do kojih se u posljednjem desetljeću dolazi u okviru različitih modela i neka recentnija istraživanja u hrvatskome potvrđuju postojanje očitih međujezičnih razlika s obzirom na obilježja samoga jezika. Time upućuju na neopravdanost donošenja zaključaka o mehanizmima obrade oslanjanjem isključivo na spoznaje u drugim, strukturno drugačijim, jezicima.

U ovom će se istraživanju stoga otići korak dalje i pomirit će se dosadašnje spoznaje o utjecaju različitih (ne)jezičnih čimbenika na sintaktičku obradu. Većinu će ih se kontrolirati kako bi se isključio njihov utjecaj na rezultate i tako izbjegla istraživačka pristranost, a nekima će se manipulirati kako bi se mogli izolirati upravo njihovi učinci. Ispitat će se predviđanja konstrualne hipoteze o utjecaju vrste imenske skupine na preferencije vezivanja, ali će se razmotriti i utjecaj drugih čimbenika koji mogu utjecati na sintaktičku obradu. Kombinirat će se metode u odgođenom i stvarnom vremenu, a ispitne će rečenice biti takve da dozvoljavaju međusobnu usporedbu u objema metodama. Usporedba će rezultata dviju metoda dodatno biti omogućena i odabirom sudionika. Naime, kako bi se isključio utjecaj individualnih razlika na rezultate, isti će sudionici sudjelovati i u ispunjavanju upitnika i u ispitivanju u stvarnom vremenu, a odabir pojedinaca za sudjelovanje u drugom dijelu eksperimenta temeljit će se na postignućima na zadatku raspona radnoga pamćenja. 


\section{CILJEVI I PRETPOSTAVKE ISTRAŽIVANJA}

\subsection{Cilj istraživanja}

Glavni je cilj ovoga rada ispitati o kojim strukturno-značenjskim osobitostima imenskih skupina koje prethode odnosnoj zamjenici ovise sintaktička obrada i način na koji govornici hrvatskoga tumače odnosne rečenice. Teorijske postavke prikazane u uvodu povezat će se s istraživačkim nacrtom u kojem će se parametri obrade analizirati i u odgođenom i u stvarnom vremenu. Takav pristup može dati širu sliku automatskih procesa obrade u stvarnom vremenu, kao i onih kasnijih u kojima vremenski parametri obrade nisu razvidni. Analizirat će se obilježja i načela ustroja ispitanih jezičnih struktura kako bi se proniknulo u njihov utjecaj na obradu, a spoznaje će se usporediti s onima iz drugih jezika te objasniti s obzirom na ishodišni model i druge postojeće teorijske pristupe.

Dodatni je cilj ovoga rada na temelju rezultata istraživanja doći do relevantnih spoznaja za hrvatski jezik te time doprinijeti širem općelingvističkom, ali i jezično-specifičnom kontekstu. Na koncu će se predložiti mogućnosti daljnje razrade ove složene tematike.

Konačno, nacrt je istraživanja takav da omogućuje stjecanje uvida u to dolazi li prilikom sintaktičke obrade do kompeticije u obradi (što zagovaraju interaktivni modeli) ili govornici unaprijed grade isključivo jednu interpretaciju rečenice (što zagovaraju modularni, i modeli neograničene utrke). Iako sama konstrualna hipoteza ne tumači ove pojavnosti, odnosno nema pretpostavki u pogledu serijalnosti i paralelnosti u obradi, rezultati mogu biti vrijedni u širem kontekstu istraživanja jezične obrade. 


\subsection{Pretpostavke istraživanja}

Sukladno postavkama konstrualne hipoteze, pretpostavlja se da će obrada ispitanih odnosnih rečenica ovisiti o njihovim strukturno-značenjskim osobitostima, tj. da će preferencija vezivanja na prvu ili drugu imenicu i krajnje tumačenje rečenica ovisiti o odnosima imenica koje prethode relativizatoru. Usprkos donekle jasnim predviđanjima obrade odnosnih rečenica (posebice ako su imenske skupine dijelom prijedložno-padežnog izraza), konstrualna je hipoteza zbog proturječnih rezultata dosadašnjih istraživanja i danas ograničena u svojim dosezima. Upravo su se uočena ograničenja uzela u obzir u ovom istraživanju.

H.1. S obzirom na prvo predviđanje konstrualne hipoteze i dosadašnja istraživanja obrade odnosnih rečenica u hrvatskome, pretpostavlja se da će postojati opća preferencija vezivanja na prvu imenicu unutar složene imenske skupine u genitivnoj dopuni.

H.2. S obzirom na drugo predviđanje konstrualne hipoteze, ako su imenice unutar imenske skupine povezane prijedlogom s mogućnošću tematskog označavanja i prebacivanja fokusa, pretpostavlja se da će postojati preferencija vezivanja na drugu imenicu unutar složene imenske skupine.

H.3. S obzirom na obilježja hrvatske sintakse i prethodna istraživanja, pretpostavlja se da će u nedostatku morfoloških obavijesti (ključeva) obilježje živosti olakšati sintaktičku obradu i utjecati na promjene preferencija govornika. 


\section{PREGLED EKSPERIMENATA}

Prema Payne i sur. (2014) te Hemforth i sur. (2015), kako bi se vjerodostojno ispitale međujezične i unutarjezične razlike u obradi, potrebno je kontrolirati raspon radnoga pamćenja sudionika te provesti ujednačena istraživanja obrade dvosmislenih i nedvosmislenih, tj. rečenica u kojima je dvosmislenost u rečenici naknadno razriješena, bilo strukturno (sročnošću u rodu ili broju) ili značenjski (prihvatljivošću temeljenoj na znanju o svijetu). S time u vidu, a u skladu s ciljevima istraživanja, odabrani su sudionici i razvijeni materijali te su provedeni eksperimenti u odgođenom i stvarnom vremenu.

Podražaji su dvosmislene odnosne rečenice iz kojih nije razvidno na koju se imenicu unutar imenske skupine odnosna surečenica odnosi te odnosne rečenice u kojima je modifikacija jasna, odnosno eksperimentalno kontrolirana. Prije provedbe eksperimenata, neovisni su sudionici ocijenili valjanost razvijenih materijala, budući da je dio njih ovisan o morfosintaktičkom, a dio o enciklopedijskom znanju. Drugim riječima, vezivanje na prvu ili drugu imenicu u jednom se eksperimentu nameće sročnošću u rodu, a u drugome značenjskom prihvatljivošću.

U poglavlju 10.1. Razvoj ispitnih podražaja opisujemo način na koji su oblikovani ispitni podražaji i materijali, s detaljnim osvrtom na sve čimbenike koji su se kontrolirali, kako bi se isključio njihov utjecaj na rezultate istraživanja, odnosno samu sintaktičku obradu. Nakon toga prikaza opisujemo provedbu istraživanja iznoseći metodološke postupke triju provedenih eksperimenata (poglavlja 10.2. Eksperiment u odgođenom vremenu-10.4. Drugi eksperiment u stvarnom vremenu). 


\subsection{Razvoj ispitnih podražaja}

Ciljane rečenice u ovom istraživanju uključivale su odnosne rečenice s konstrukcijom

$$
N P \text { - relativizator - odnosna surečenica - glavna surečenica, }
$$

pri čemu je imenska skupina bila u genitivnoj dopuni ili je činila prijedložno-padežni izraz (imenice povezane prijedlozima $u$ i $n a$ ). Činjenica da su genitivni odnosi u hrvatskome posebno složeni i da se tvore na drugačiji način nego u engleskome ili španjolskome jeziku (vidi poglavlje 5.3. Genitivne dopune u hrvatskome), kao i spoznaje o utjecaju ostalih jezičnih čimbenika na obradu (vidi poglavlje 6.2. Obilježja jezičnih struktura), predstavljaju dodatne zahtjeve za razvoj podražaja. Iako je važno kontrolirati eksperimentalni nacrt, uz to valja poštivati strukturu i zakonitosti jezika. U suprotnome rezultati ne odražavaju stvarnu sliku sintaktičke obrade. Podražaji su stoga oblikovani isključivo za potrebe ovoga doktorskog istraživanja, a njihova je kontrola uključivala: 1) subjektni položaj imenske skupine; 2) ujednačenost duljina regija koje su predviđene za daljnje analize; 3) ujednačenost čestotnosti imenica unutar imenske skupine; 4) ujednačenost obilježja broja imenica; te naposljetku 5) ujednačenost ili namjernu manipulaciju rodom i značenjskom prihvatljivošću čitave strukture. Ispravnost, odnosno ovjerenost i valjanost podražaja prethodno su procijenili neovisni sudionici, a statističkim je metodama valjanost dodatno potvrđena.

Ispitivanja u odgođenom vremenu sastoje se od upitnika (zadatak prosudbe) u kojem su ispitne rečenice uvijek dvosmislene, odnosno iz kojih nije razvidno na koju se imenicu unutar složene imenske skupine odnosna surečenica odnosi. Ispitivanja u stvarnom vremenu sastoje se od odnosnih rečenica u kojima je modifikacija eksperimentalno kontrolirana (na način da se surečenica može odnositi samo na prvu ili samo na drugu imenicu unutar imenske skupine). Budući da će se rezultati uspoređivati, rečenice su ujednačene. Drugim riječima, dvosmislenoj odnosnoj rečenici koja je podražaj u zadatku prosudbe, za potrebe drugog ispitivanja u stvarnom vremenu izmijenjen je upravo onaj segment koji se ispituje, odnosno prva ili druga imenica, kako bi se stvorio eksperimentalan uvjet vezivanja na prvu ili drugu imenicu (izv. eng. forced local ili forced non-local attachment preference). Prva i druga imenica uvijek su bile u nominativu jednine. 


\section{Primjer (genitivna dopuna):}

Tvornica čokolade koja je proslavila zemlju trenutno je na svim vijestima. - dvosmislena, ispitivanje u odgođenom vremenu

Tvornica sira* što je proslavila zemlju trenutno je na svim vijestima. - eksperimentalna kontrola modifikacije prve imenice unutar NP, manipulacija sročnošću u rodu

Festival* čokolade što je proslavila zemlju trenutno je na svim vijestima. - eksperimentalna kontrola modifikacije druge imenice unutar NP, manipulacija sročnošću u rodu

\section{Primjer (prijedložno-padežni izraz):}

Stazica u šumi koja je prepuna stakla česta je tema među seljanima. - dvosmislena, ispitivanje u odgođenom vremenu

Stazica u parku* što je prepuna stakla česta je tema među seljanima. - eksperimentalna kontrola modifikacije prve imenice unutar NP, manipulacija sročnošću u rodu

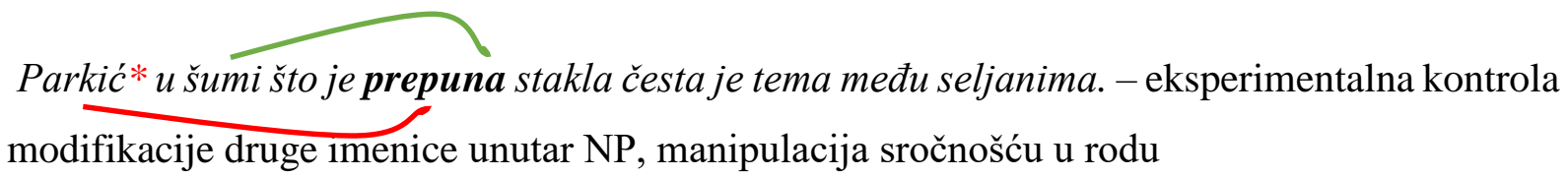

Glavna je rečenica uvijek bila u prezentu i nije bila obilježena rodom: ${ }^{41}$

... svojim izgledom iznenađuje goste.

... važna je tema među stanarima.

... zastrašuje svu djecu u selu.

... oduševljava sve ljude u publici.

\footnotetext{
${ }^{41} \mathrm{Da}$ su rečenice napisane u perfektu, obavijest o rodu bila bi dostupna na nekoliko mjesta u rečenici, odnosno unutar više regija predviđenih za daljnju analizu, što nije preporuka u eksperimentima poput ovoga. Naime, ključni segment kojim se manipulira u zadatku mora biti dostupan samo na jednom mjestu u rečenici.
} 
... iscrpljuje sve sudionike natjecanja.

... privlači sve ljude u prostoriji. Popis svih rečenica nalazi se u Prilozima.

Drugi eksperiment u stvarnom vremenu uključivao je drugačiju vrstu eksperimentalne manipulacije. Sve su imenice bile u muškome rodu i u jednini, ali su se varirali odnosi živosti (jedna je imenica imala obilježje živo, a druga neživo, a odnosna se surečenica značenjski mogla odnositi samo na živo ili samo na neživo). Manipulacija značenjskom prihvatljivošću druga je mogućnost manipulacije podražajima u sličnim istraživanjima, a posebno je važna zbog stjecanja uvida u strukturno-značenjske čimbenike u jeziku koji mogu utjecati na preferencije vezivanja, što je važnije od toga vezuje li se u jeziku češće na prvu ili drugu imenicu. Kao i u prvom eksperimentu u stvarnom vremenu, ponovno je izmijenjen upravo onaj segment koji se ispituje, odnosno prva ili druga imenica, kako bi se stvorio eksperimentalan uvjet vezivanja na prvu ili drugu imenicu. Posebna se pažnja posvetila ispravnoj konstrukciji genitivnih odnosa u hrvatskome. Iz ovoga razloga nisu upotrijebljene konstrukcije od + genitiv*, kao ni konstrukcije poput bend pjevača* ili brod kapetana*. Iako bi to iz eksperimentalne perspektive pojednostavilo izradu podražaja i nacrt istraživanja, nije opravdano narušiti jezik za potrebe istraživačkoga nacrta.

\section{Primjer (vezivanje na imenicu živo):}

Sin poznatog pjevača koji ima srčanu manu glavna je tema u dvorani. - dvosmislena, ispitivanje u odgođenom vremenu

Pjevač poznatog benda* koji ima srčanu manu glavna je tema u dvorani. - eksperimentalna kontrola modifikacije prve imenice unutar NP, manipulacija značenjskom prihvatljivošću

Bend* poznatog pjevača koji ima srčanu manu glavna je tema u dvorani. - eksperimentalna
kontrola modifikacije druge imenice unutar NP, manipulacija značenjskom prihvatljivošću 


\section{Primjer (vezivanje na imenicu neživo):}

Podrum starog stana koji je prepun smeća živcira baš sve ljude u zgradi. - dvosmislena, ispitivanje u odgođenom vremenu

Stan starog vlasnika* koji je prepun smeća živcira baš sve ljude u zgradi. - eksperimentalna kontrola modifikacije prve imenice unutar NP, manipulacija značenjskom prihvatljivošću

Vlasnik* starog stana koji je prepun smeća živcira baš sve ljude u zgradi. - eksperimentalna kontrola modifikacije druge imenice unutar NP, manipulacija značenjskom prihvatljivošću

Ponovno su sve rečenice bile u prezentu, a glavna se rečenica mogla odnositi i na imenicu s obilježjem živo i na onu s obilježjem neživo:

... veoma je drag svim mještanima.

... glavna je tema svake kave.

... opet je uzrokom brojnih svađa.

... svima je uljepšao ljetnu večer.

... živcira baš sve ljude u zgradi.

... u svima stvara veliku nervozu. Popis svih rečenica nalazi se u Prilozima.

Kako bi se spriječilo oslanjanje na prozodijsku segmentaciju koja utječe na obradu rečenica (Fodor, 1998; 2002), one ni u jednom zadatku nisu sadržavale zareze.

\subsubsection{Položaj imenske skupine}

Budući da subjektni ili objektni položaj imenske skupine znatno utječe na interpretaciju odnosnih rečenica (Hemforth i sur., 2015), za potrebe ovog istraživanja imenske su skupine uvijek bile u subjektnom položaju. Na taj se način izbjegla preferencija prema prvoj imenici isključivo zbog njezina objektnog položaja. Time se ujedno utjecalo i na duljinu čitave rečenice jer metoda istraživanja zahtijeva da one budu prikazane u jednome retku (vidi poglavlje 7.2.2. Metoda praćenja pokreta očiju). 
10.1.2. Duljina relevantnih dijelova rečenice

Istraživanja u stvarnom vremenu podrazumijevaju analizu obilježja pokreta oka na prethodno utvrđenim interesnim zonama ili regijama interesa (izv. eng. areas of interest) $\mathrm{u}$ ispitnim rečenicama. Iz toga je razloga nužno da regije koje se uspoređuju budu jednake duljine, odnosno da svi relevantni rečenični dijelovi imaju jednak broj slovnih mjesta. U suprotnome se ne bi mogla isključiti mogućnost da je dulje vrijeme čitanja posljedica veće regije interesa, a ne teškoća u obradi (Rayner, 1998). Iz toga su razloga sve rečenice i važne regije interesa u svim uvjetima ujednačene. Informacije o duljini regija interesa i načinu njihove segmentacije za daljnju analizu prikazane su u nastavku. Tablice 3a i 3b prikazuju ukupne vrijednosti za oba uvjeta u eksperimentima, dok Tablice 4a i 4 b prikazuju pojedinačne vrijednosti za svaki od uvjeta u obama eksperimentima.

Tablica 3a. Raspon ukupnog $N$ grafema, $N$ riječi u rečenici te slovne duljine relevantnih regija (prvi eksperiment, oba uvjeta).

\begin{tabular}{ll}
\multicolumn{1}{c}{ Promatrana vrijednost } & \multicolumn{1}{c}{$\begin{array}{c}\text { Raspon } \\
\text { (sr. vrijednost) }\end{array}$} \\
\hline \hline$N$ grafema & $51-62(57,5)$ \\
\hline$N$ riječi u rečenici & $10-12(11,2)$ \\
\hline Slovna duljina NP & $10-16(12,3)$ \\
\hline Slovna duljina regije gramatičkog razrješenja dvosmislenosti & $13-18(14,1)$ \\
\hline Slovna duljina regije nakon razrješenja & $11-16(13)$ \\
\hline Slovna duljina finalne regije & $10-19(14,3)$ \\
\hline
\end{tabular}

Tablica 3b. Raspon ukupnog $N$ grafema, $N$ riječi u rečenici te slovne duljine relevantnih regija (drugi eksperiment, oba uvjeta).

\begin{tabular}{ll}
\multicolumn{1}{c}{ Promatrana vrijednost } & \multicolumn{1}{c}{$\begin{array}{c}\text { Raspon } \\
\text { (sr. vrijednost) }\end{array}$} \\
\hline$N$ grafema & $55-63(59,8)$ \\
\hline$N$ riječi u rečenici & $11-13(12,2)$ \\
\hline Slovna duljina NP & $13-19(17,1)$ \\
\hline Slovna duljina regije značenjskog razrješenja dvosmislenosti & $11-15(13,2)$ \\
\hline Slovna duljina regije nakon razrješenja & $11-15(12,9)$ \\
\hline Slovna duljina finalne regije & $8-17(12,2)$ \\
\hline
\end{tabular}


U tabličnim su prikazima u nastavku osjenčane regije koje su namijenjene daljnjoj analizi (regije interesa), a strjelicama su povezani uvjeti koji se međusobno uspoređuju.

Tablica 4a. Srednje vrijednosti za $N$ grafema i riječi te $N$ slovnih mjesta u ključnim regijama interesa za oba uvjeta (prvi eksperiment).

\begin{tabular}{lcc}
\multicolumn{1}{c}{ Promatrana vrijednost } & $\begin{array}{c}\text { Uvjet: genitivna } \\
\text { dopuna }\end{array}$ & $\begin{array}{c}\text { Uvjet: prijedložno-padežni } \\
\text { izraz }\end{array}$ \\
\hline \hline$N$ grafema & 60,9 & 56,2 \\
\hline$N$ riječi & 10,5 & 11,8 \\
\hline Duljina NP & 12,8 & 11,7 \\
\hline $\begin{array}{l}\text { Duljina regije gramatičkog } \\
\text { razrješenja }\end{array}$ & 14,8 & 15 \\
\hline Duljina regije nakon razrješenja & 13,2 & 12,8 \\
\hline Duljina finalne regije & 16 & 12,7 \\
\hline
\end{tabular}

Tablica 4b. Srednje vrijednosti za $N$ grafema i riječi te $N$ slovnih mjesta u ključnim regijama interesa za oba uvjeta (drugi eksperiment).

\begin{tabular}{lcc}
\multicolumn{1}{c}{ Promatrana vrijednost } & $\begin{array}{c}\text { Uvjet: vezivanje na } \\
\text { živo }\end{array}$ & $\begin{array}{c}\text { Uvjet: vezivanje na } \\
\text { neživo }\end{array}$ \\
\hline \hline$N$ grafema & 58,7 & 60,8 \\
\hline$N$ riječi & 12 & 12,3 \\
\hline Duljina NP & 17,2 & 17 \\
\hline $\begin{array}{l}\text { Duljina regije značenjskog } \\
\text { razrješenja }\end{array}$ & 13,3 & 13 \\
Duljina regije nakon razrješenja & 13 & 12,8 \\
\hline Duljina finalne regije & 10,8 & 13,5 \\
\hline
\end{tabular}




\subsection{3. Čestotnost imenica unutar imenske skupine}

Kako bi se izbjegla mogućnost da je dulje vrijeme čitanja ciljane regije uvjetovano manjom čestotnosti riječi u odnosu na riječi iz druge regije interesa (Rayner i Duffy, 1986; Rayner, 2009; Palmović i sur., u tisku), sve su imenice unutar imenske skupine ujednačene po čestotnosti. Podatci o čestotnosti preuzeti su iz hrvatskog web korpusa hrWac (Ljubešić i Klubička, 2016) koji broji više od 1,397,757,548 pojavnica, a u obzir su se uzimale samo riječi visoke čestotnosti.

Iako je granica visoke $\mathrm{i}$ niske čestotnosti $\mathrm{u}$ istraživanjima često arbitrarna, $\mathrm{u}$ ovom se istraživanju vodimo kriterijem da su visokočestotne riječi one koje se u korpusima pojavljuju u omjerima 100 ili više puta na milijun riječi, a niskočestotne one koje se pojavljuju 10 ili manje puta na milijun riječi (Morrison i Ellis, 1995).

U skladu s navedenim kriterijem, u ovom je istraživanju prosječna relativna čestotnost riječi po uvjetu morala biti veća od 0,001\% (Tablica 5).

Tablica 5. Prosječne vrijednosti čestotnosti riječi u svim uvjetima i obama eksperimentima.

\begin{tabular}{cc||cc}
\hline $\begin{array}{c}\text { Prvi eksperiment: } \\
\text { uvjet }\end{array}$ & $\begin{array}{c}\text { Cestotnost } \\
\text { (rel. vrijednost) }\end{array}$ & $\begin{array}{c}\text { Drugi eksperiment: } \\
\text { uvjet }\end{array}$ & $\begin{array}{c}\check{C} \text { estotnost } \\
\text { (rel. vrijednost) }\end{array}$ \\
\hline \hline Genitivna dopuna & $\begin{array}{c}184145,7 \\
(0,013)\end{array}$ & Vezivanje na živo & $\begin{array}{c}172525,9 \\
(0,012)\end{array}$ \\
\hline $\begin{array}{c}\text { Prijedložno-padežni } \\
\text { izraz }\end{array}$ & $\begin{array}{c}182128,2 \\
(0,013)\end{array}$ & Vezivanje na neživo & $\begin{array}{c}189741,4 \\
(0,014)\end{array}$ \\
\hline
\end{tabular}

U nastavku su tablično prikazane srednje vrijednosti čestotnosti imenica unutar imenske skupine u svim ispitanim uvjetima i u obama provedenim eksperimentima. Osim toga, prikazane su i vrijednosti statističkih testova za testiranje značajnosti razlika u čestotnosti imenica (Tablice 6 i 7). 
Tablica 6. Srednja vrijednost čestotnosti imenica unutar NP u različitim uvjetima i prikaz rezultata $t$-testa za testiranje razlika u čestotnosti (prvi eksperiment).

\begin{tabular}{|c|c|c|c|c|c|c|}
\hline \multirow{2}{*}{ Uvjeti / podražaji } & \multicolumn{2}{|c|}{ Dvosmislena } & \multicolumn{2}{|c|}{ Vezivanje na N1 } & \multicolumn{2}{|c|}{ Vezivanje na N2 } \\
\hline & N1 & $\mathrm{N} 2$ & N1 & $\mathrm{N} 2$ & N1 & $\mathrm{N} 2$ \\
\hline Genitivna dopuna & 110757,5 & 212482,5 & 110757,5 & 280912 & 120457,8 & 212482,5 \\
\hline $\begin{array}{c}\text { Prijedložno-padežni } \\
\text { izraz }\end{array}$ & 247684 & 192439,7 & 247684 & 132647,5 & 155741,5 & 192439,7 \\
\hline NP ukupno & 179220,8 & 202461,1 & 179220,8 & 206779,8 & 138099,7 & 202461,1 \\
\hline \multicolumn{7}{|l|}{ GD vs PPI ( $t$-test) } \\
\hline$p$ & 0,086 & 0,710 & 0,086 & 0,240 & 0,529 & 0,710 \\
\hline \multicolumn{7}{|l|}{ N1 vs N2 (t-test) } \\
\hline$p$ & \multicolumn{2}{|c|}{0,797} & \multicolumn{2}{|c|}{0,724} & \multicolumn{2}{|c|}{0,315} \\
\hline
\end{tabular}

Tablica 7. Srednja vrijednost čestotnosti imenica unutar NP u različitim uvjetima i prikaz rezultata $t$-testa za testiranje razlika $\mathrm{u}$ čestotnosti (drugi eksperiment).

\begin{tabular}{|c|c|c|c|c|}
\hline \multirow{2}{*}{ Uvjeti / podražaji } & \multicolumn{2}{|c|}{ Dvosmislena } & \multicolumn{2}{|c|}{ Vezivanje na N1/N2* } \\
\hline & N1 & $\mathrm{N} 2$ & $\check{Z}$ & Nž \\
\hline Vezivanje na Ž & 206072 & 133197,7 & 133197,7 & 178307,8 \\
\hline Vezivanje na Nž & 101935,3 & 301331,2 & 165957,8 & 301331,2 \\
\hline NP ukupno & 154003,8 & 217264,4 & 149577,6 & 239819,5 \\
\hline $\begin{array}{c}\check{Z} \text { vs Nž i N1 vs N2 } \\
(t \text {-test })^{*}\end{array}$ & \multicolumn{2}{|c|}{ Ž/Nž vs Ž/Nž } & $\mathrm{N} 1$ vs N2 & Ž vs NŽ \\
\hline$p$ & \multicolumn{2}{|c|}{0,309} & 0,173 & 0,510 \\
\hline
\end{tabular}

*Za razliku od prethodnoga tabličnog prikaza usporedbe čestica (Tablica 6), u ovome prikazu vezivanje na N1 ili N2 nije izdvojeno u posebnim stupcima. Tomu je tako jer N1 iz prvoga uvjeta u drugom uvjetu postaje $\mathrm{N} 2$ i obrnuto (primjerice, pjevač poznatog benda i bend poznatog pjevača).

Kako pokazuju posljednji redovi u Tablicama 6 i 7, vrijednosti $t$-testa za testiranje razlika u čestotnosti imenica unutar NP u svim su eksperimentima i svim uvjetima $p>0,05$. Nedostatak 
statističke značajnosti u uspoređenim vrijednostima dokazuje da se imenice koje su dijelovima ispitnih podražaja ni u jednom uvjetu ne razlikuju u čestotnosti. Time se isključuje mogućnost da eventualne razlike u preferencijama ili brzini obrade koje se $u$ istraživanju mogu ustanoviti budu uzrokovane razlikama u čestotnosti riječi u ispitnim podražajima koji se međusobno uspoređuju.

\subsubsection{Predispitivanja: utvrđivanje valjanosti podražaja}

U prethodnim poglavljima prikazan je način izrade podražaja i kontrole strukturnih i eksperimentalnih čimbenika koji utječu na sintaktičku obradu i analizu rezultata. Kako bi se pak osigurala valjanost tih podražaja, prethodno se zadatcima sročnosti i značenjske prihvatljivosti provjerila njihova ovjerenost. $U$ oba su ta predispitivanja valjanost podražaja ocijenili neovisni sudionici koji nisu sudjelovali u glavnom istraživanju i nisu bili upoznati s njegovim ciljem. Slijedi prikaz i postupak provedbe tih dvaju predispitivanja, kao i njihovih ishoda.

\subsubsection{Zadatak sročnosti}

U prvom se eksperimentu u stvarnom vremenu manipuliralo sročnošću u rodu, zbog čega su sve rečenice prethodno bile podvrgnute zadatku provjere sročnosti (izv. eng. agreement pretest). Ova je manipulacija jedna od mogućnosti razrješavanja početne dvosmislenosti u sličnim istraživanjima, ali je i jedan od preduvjeta razrješavanju i postojanju dvosmislenosti uopće, posebice u hrvatskome.

Predispitivanjem se stoga osigurava da je u glavnom istraživanju sudionikova preferencija vezivanja na prvu ili drugu imenicu u dvosmislenoj rečenici isključivo rezultat njegove/njezine automatske odluke budući da je prethodno ustanovljeno (i statistički potvrđeno) da su obje mogućnosti tumačenja jednako vjerojatne. Osim toga, ovim se postupkom osigurava i da je u preostalim dvama uvjetima isključena mogućnost da se surečenica odnosi na prvu, tj. drugu imenicu, ponovno iz razloga što su neovisni ocjenjivači prethodno procijenili da alternativna mogućnost tumačenja nije moguća.

Postupak provedbe predispitivanja. U predispitivanju ocjene ispitnih podražaja (zadatak sročnosti) sudjelovalo je 20 neovisnih sudionika, studenata diplomskoga studija. Svi su izvorni 
jednojezični govornici hrvatskoga jezika bez povijesti jezičnih teškoća, dobnoga raspona od 21;07-22;09 (prosječna $\mathrm{KD}=22 ; 03$ ). U vrijeme predispitivanja nisu bili upoznati s ciljem glavnog istraživanja i jedina pismena uputa koja im je dana bila je da pažljivo čitaju rečenice i procijene njihovu gramatičku ispravnost, bez oslanjanja na osobno iskustvo, mišljenje ili stav o sadržaju. Pismena uputa izgledala je ovako:

Pred Vama se nalazi nekoliko kratkih tvrdnji. Neke Vam se mogu činiti pomalo smiješnima, ali Vaš je zadatak samo odrediti koliko je svaka od njih gramatički ispravna. Nakon što pročitate tvrdnju, odgovorite pridavanjem oznake (primjerice, + ili $\checkmark$ ili $x$ ) ispod riječi ISPRAVNO ili NEISPRAVNO, pri čemu ISPRAVNO predstavlja potpuno GRAMATIČKI ISPRAVNU rečenicu, a NEISPRAVNO u potpunosti GRAMATIČKI POGREŠNU rečenicu. Tvrdnju Čokolada je jako gorka označit ćete s ISPRAVNO jer je ta rečenica gramatički ispravna. S druge strane, tvrdnju Čokolada je jako gorak označit ćete s NEISPRAVNO jer ona nije ispravna. Prilikom rješavanja zadatka ne razmišljajte je li Vama osobno čokolada gorka ili npr. slatka, već ocjenu temeljite ISKLJUČIVO na gramatičkoj ispravnosti, odnosno sročnosti.

Ukupno 48 rečenica prethodno je oblikovano po već navedenim i opisanim kriterijima (čestotnost imenica, duljina rečenica, odnosi imenica unutar NP). Rečenice su poredane nasumičnim redoslijedom u računalnom programu, a po završetku postupka bodovane vrijednostima 1 ili 0 . Bod (1) dodijeljen je ako je rečenica ocijenjena kao ispravna, a 0 ako je ocijenjena kao neispravna, neovisno o tome je li pritom sudionikov odgovor točan.

Rezultati su pokazali da je u dvosmislenoj rečenici doista moguća modifikacija obiju imenica unutar NP (Tablica 8). Jednako tako, potvrđeno je da je u preostalim dvama uvjetima (vezivanje na N1 i N2) isključena mogućnost da se surečenica odnosi na prvu (u uvjetu vezivanja na N2), tj. drugu imenicu (u uvjetu vezivanja na N1). Drugim riječima, neovisni su ocjenjivači procijenili da takvo tumačenje nije moguće, za što je dobivena i statistička potvrda. U dvosmislenom uvjetu statistički značajne razlike između imenica unutar imenske skupine nema, dok je ona značajna u preostalim dvama uvjetima. 
Tablica 8. Prosječne vrijednosti bodova na zadatku sročnosti po uvjetima i testiranje značajnosti razlika među uvjetima.

\begin{tabular}{cccc} 
& Dvosmislena & Vezivanje na N1 & Vezivanje na N2 \\
\hline \hline N1: Sr.v. (St.d.) & $0,996(0,014)$ & $0,996(0,01)$ & $0,017(0,023)$ \\
\hline N2: Sr.v. (St.d.) & $1(0)$ & $0(0)$ & $1(0)$ \\
\hline$p$ (N1/N2) & 0,339 & $0,00^{* *}$ & $0,00^{* *}$ \\
\hline
\end{tabular}

\subsubsection{Zadatak značenjske prihvatljivosti}

U drugom se eksperimentu manipuliralo značenjskom prihvatljivošću, zbog čega su sve rečenice prethodno podvrgnute zadatku provjere značenjske prihvatljivosti (izv. eng. semantic plausibility pretest), drugom uobičajenom postupku za utvrđivanje valjanosti podražaja.

Njime se ponovno osigurava da su obje mogućnosti tumačenja jednako vjerojatne, odnosno da je u glavnom istraživanju sudionikova preferencija u dvosmislenoj rečenici isključivo rezultat njegove/njezine automatske odluke budući da je to prethodno ustanovljeno (i statistički potvrđeno). Postupkom se osigurava i da je u preostalim dvama uvjetima isključena mogućnost da se surečenica odnosi na prvu, tj. drugu imenicu, ponovno iz razloga što su neovisni ocjenjivači prethodno procijenili da alternativna mogućnost tumačenja nije moguća, odnosno da alternativno tumačenje nije značenjski prihvatljivo.

Postupak provedbe predispitivanja. U drugome predispitivanju ocjene ispitnih podražaja (zadatak značenjske prihvatljivosti) sudjelovalo je 23 neovisnih sudionika, studenata diplomskoga studija. Svi su izvorni jednojezični govornici hrvatskoga jezika bez povijesti jezičnih teškoća, dobnoga raspona od 21;11-28;07 (prosječna $\mathrm{KD}=22 ; 08$ ). U vrijeme predispitivanja nisu bili upoznati s ciljem glavnog istraživanja. Nisu sudjelovali ni u prethodno opisanoj ocjeni valjanosti ispitnih podražaja (zadatku sročnosti), ni u glavnom istraživanju. Budući da je ovaj zadatak procjene različit od prethodno opisanoga, i uputa se razlikovala od prethodne. Izgledala je ovako:

Vaš je zadatak odrediti koliko je svaka od sljedećih situacija/tvrdnji moguća, odnosno koliko je moguće da se tako nešto dogodi. Nakon što pročitate pitanje, odgovorite pridavanjem brojke ovisno o stupnju vjerojatnosti da je navedena 
situacija moguća, tj. ovisno o stupnju njezine prikladnosti. Odgovarajte brojkama 0-7, pri čemu 0 predstavlja potpuno nemoguću situaciju, a 7 u potpunosti prikladnu i moguću situaciju. Pripazite, situacije se ne odnose na konkretan slučaj, već samo na opću prikladnost, tj. mogućnost da se općenito u svijetu tako nešto dogodi. Primjerice, na pitanje: Može li sestra lijepo pjevati? Odgovorit ćete sa 7 jer je to zaista moguće (pri tome ne razmišljajte imate li Vi sestru i pjeva li ona lijepo). Na pitanje: Može li sunce lijepo pjevati? Odgovorit ćete sa 0 jer ova situacija zaista nije moguća.

Ukupno 48 rečenica prethodno je oblikovano po već navedenim i opisanim kriterijima (čestotnost imenica, duljina rečenica, odnosi imenica unutar NP). Poredane su nasumičnim redoslijedom u računalnom programu, a po završetku postupka bodovane vrijednostima od 0 do 7, u skladu s ocjenama koje su im dodijeljene.

Rezultati prikazani u Tablici 9 pokazuju da je u dvosmislenoj rečenici doista moguća modifikacija obiju imenica unutar NP. Jednako tako, potvrđeno je da je u preostalim dvama uvjetima (vezivanje na N1 i N2) isključena mogućnost da se surečenica odnosi na prvu (u uvjetu vezivanja na N2), tj. drugu imenicu (u uvjetu vezivanja na N1). Drugim riječima, neovisni su ocjenjivači procijenili da alternativno tumačenje nije moguće jer ne odgovara enciklopedijskome znanju (primjerice, roman ne može biti ubijen, ali pisac može), što je i statistički potvrđeno. U dvosmislenom uvjetu statistički značajne razlike u značenjskoj prihvatljivosti imenica unutar imenske skupine nema, dok je ona značajna u preostalim dvama uvjetima.

Tablica 9. Prosječne vrijednosti bodova na zadatku značenjske prihvatljivosti po uvjetima i testiranje značajnosti razlika među uvjetima.

\begin{tabular}{cccc} 
& Dvosmislena & Vezivanje na N1 & Vezivanje na N2 \\
\hline \hline N1: Sr.v. (St.d.) & $6,938(0,063)$ & $6,942(0,097)$ & $0,551(0,768)$ \\
\hline N2: Sr.v. (St.d.) & $6,920(0,127)$ & $0,551(0,768)$ & $6,942(0,097)$ \\
\hline$p$ (N1/N2) & 0,633 & $0,00^{* *}$ & $0,00^{* *}$ \\
\hline
\end{tabular}




\subsection{Eksperiment u odgođenom vremenu}

Upitnik, odnosno zadatak prosudbe u odgođenom vremenu, oblikovan je kako bi se ispitalo konačno tumačenje dvosmislenih odnosnih rečenica, tj. kako bi se utvrdile preferencije vezivanja ili odabir antecedenta na koji se surečenica odnosi, prvenstveno u okviru konstrualne hipoteze. Ovom se metodom mogu ispitati postavke različitih modela spomenutih u uvodu i stoga je ona razmjerno učestala u sličnim istraživanjima u različitim jezicima. Pretpostavka je da sudionikov odgovor predstavlja njegovo konačno tumačenje dvosmislenih odnosnih rečenica te da je kao takav valjana potvrda njegovih/njezinih preferencija vezivanja. Na umu se ipak mora imati činjenica da zadatci u odgođenom vremenu ne predstavljaju govornikov nesvjesni odgovor i kao takvi ne odražavaju procese automatske obrade. Sudionik u ovakvim zadatcima može nekoliko puta pročitati rečenicu u sebi ili naglas te mijenjati mišljenje i svoj odgovor, ovisno o tome što pretpostavlja da se od njega/nje očekuje, posebice ako zadatak rješava u prisutnosti ispitivača.

U prvome su dolasku sudionici osim upitnika ispunjavali i zadatak raspona radnoga pamćenja pri računanju, a temeljem postignuća na tom zadatku bili su odabrani za sudjelovanje u sljedećim dvama eksperimentima.

\subsubsection{Uzorak sudionika}

U istraživanju je sudjelovalo 97 odraslih osoba, izvornih govornika hrvatskoga jezika, urednoga jezičnog statusa te bez povijesti neuroloških oštećenja i razvojnih odstupanja. Sudionici su bili studenti nekoliko fakulteta Sveučilišta u Zagrebu ili osobe s visokom stručnom spremom. Demografski su podatci o sudionicima (spol i dob) prikazani u Tablici 10.

U skladu s etičkim načelima, svi su sudionici prethodno upoznati s naravi istraživanja te su potpisali suglasnost za sudjelovanjem. Zajamčena im je anonimnost, a u svakom su se trenutku mogli povući iz ispitivanja bez obveze navođenja razloga. Budući da je za mogućnost prikupljanja podataka i kasnije analize rezultata temeljem mjerenja pokreta očiju ključno da sudionici nemaju dioptriju i oštećenja oka jer to može onemogućiti kalibraciju uređaja i remetiti mjerenje, prikupljene su i informacije o statusu vida. 
Tablica 10. Obilježja (spol i dob) sudionika koji su sudjelovali u mjerenjima u odgođenom vremenu.

\begin{tabular}{|c|c|c|c|c|c|c|c|}
\hline \multirow[b]{2}{*}{ Sudionici } & \multirow{2}{*}{$\mathrm{N}$} & \multicolumn{2}{|c|}{ Spol } & \multicolumn{4}{|c|}{ Dob } \\
\hline & & $\mathrm{M}$ & Ž & Sr. dob & $\mathrm{SD}$ & Min & Maks \\
\hline & 97 & 27 & 70 & $20 ; 06$ & $2 ; 13$ & $18 ; 06$ & $31 ; 10$ \\
\hline
\end{tabular}

\subsubsection{Materijali}

\subsubsection{Podražaji u upitniku prosudbe}

Podražaje u upitniku čini dvadeset odnosnih rečenica koje su u potpunosti dvosmislene, tj. rečenice iz kojih nije razvidno koju imenicu unutar složene imenske skupine odnosna surečenica modificira. Obilježja su rečenica detaljno opisana u prethodnom poglavlju o izradi podražaja i čimbenicima koji su kontrolirani kako bi se umanjio njihov utjecaj na sintaktičku obradu. Polovicu ciljanih rečenica (njih 10) činile su odnosne rečenice u kojima su imenice u imenskoj skupini u genitivnim dopunama, a polovicu (preostalih 10) odnosne rečenice u kojima su imenice dijelom prijedložno-padežnog izraza, tj. povezane prijedlogom koji označava lokaciju ( $u$ i $n a$ ). U svim su rečenicama imenice u imenskoj skupini bile u jednini. U šest rečenica čije su imenice bile u genitivnim dopunama imenske su se skupine sastojale od imenica s obilježjem neživo/neživo, a u preostale četiri imenice s obilježjem živo/živo. U tim je četirima primjerima druga imenica unutar imenske skupine obilježena na različite načine. Označena je pridjevom ili posvojnom zamjenicom, što je ispravan način tvorbe tih vrsta genitivnih dopuna u hrvatskome jeziku. Iako je utjecaj relativizatora na obradu i preferencije vezivanja $\mathrm{u}$ hrvatskome opovrgnut (Lovrić i Fodor, 2000), odnosna je surečenica ipak u podražajima uvedena zamjenicom koji. U polovici su primjera obje imenice bile u ženskom, a u drugoj polovici u muškom rodu. Imenske su se skupine uvijek nalazile u subjektnom položaju u rečenici. Za razliku od rečenica u kojih su imenice bile u genitivnim dopunama, u svih su deset rečenica u kojih su imenske skupine bile dijelom prijedložno-padežnih izraza imenice imale obilježje neživo/neživo. Kako se ovim rečenicama izražava lokacija, kombinacija živo/živo ne bi bila značenjski i smisleno ispravna (primjerice: Učiteljica na prijateljici koja je...*). U tome su uvjetu u polovici primjera imenice bile povezane prijedlogom $u$, a $\mathrm{u}$ drugoj polovici 
prijedlogom na. Nadalje, u polovici su primjera imenice u glavnoj surečenici bile u ženskom, a u drugoj polovici u muškom rodu. Surečenice nisu bile odijeljene zarezima kako se sudionicima istraživanja ne bi sugerirala prozodijska segmentacija (Fodor, 2002; Frazier i sur., 2006). Nakon svake ispitne rečenice uslijedilo je jednostavno pitanje kojim se provjeravalo sudionikovo tumačenje rečenice, tj. razumijevanje o tome koju imenicu odnosna surečenica modificira. Primjerice:

Staza u šumi koja je prepuna stakla česta je tema među seljanima.

Što je prepuno stakla?

Staza

$\check{S} u m a$

Variralo se i mjesto odgovora na način da se u polovici primjera prva imenica unutar imenske skupine nalazila na lijevoj strani kao prvi ponuđeni odgovor, a u drugoj polovici na desnoj, kao drugi ponuđeni odgovor. Time se osiguralo da sudionici ne odgovaraju po navici. Kako bi ih se dodatno odvratilo od cilja istraživanja, upitnik je sadržavao i jednaki broj umetnutih podražaja od kojih se svaki pojavljivao nakon jedne ispitne rečenice. Umetnute su podražaje činile sastavne i suprotne rečenice. Slika 3 predstavlja grafički prikaz upravo opisane strukture upitnika, a svi se ispitni podražaji nalaze u Prilozima. 


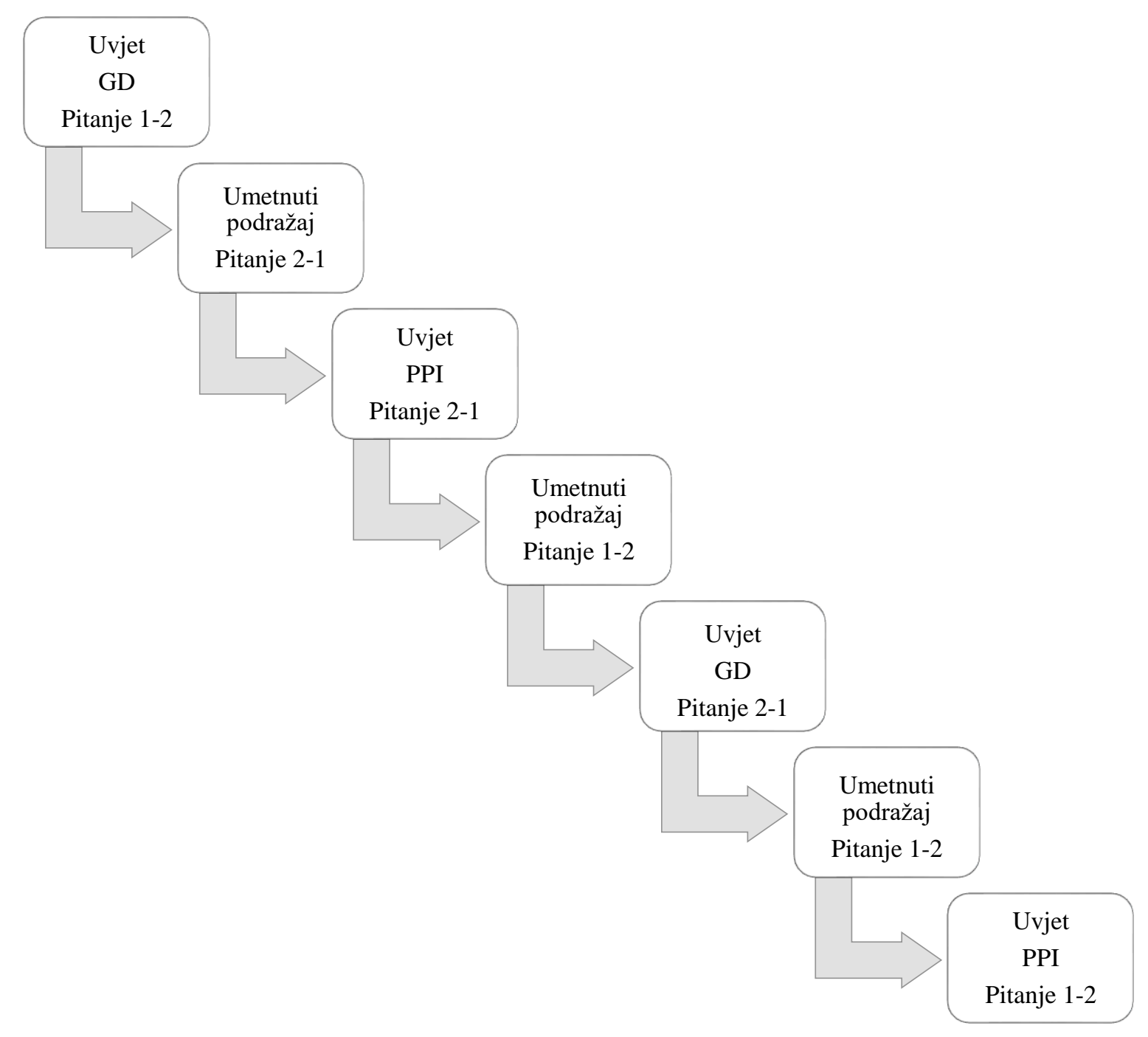

Slika 3. Sažeti prikaz strukture upitnika prosudbe (GD je genitivna dopuna; PPI je prijedložnopadežni izraz).

\subsubsection{Mjera raspona radnoga pamćenja}

Raspon radnoga pamćenja mjeren je Automatiziranim zadatkom raspona radnoga pamćenja pri računanju (AOSPAN), odnosno njegovom skraćenom inačicom (Foster i sur., 2015) koja je prethodno prevedena i prilagođena za hrvatski jezik (Matić i Palmović, 2018). U zadatku se od sudionika traži da pamti niz nepovezanih grafema koji se pojavljuju na zaslonu računala, istovremeno rješavajući niz jednostavnih matematičkih zadataka. Uloga je toga dodatnoga zadatka računanja izbjeći da osoba ponavlja verbalnu informaciju zadržavajući je na taj način isključivo u kratkoročnome pamćenju. Logička pozadina za uporabu upravo ovoga zadatka detaljno je opisana u poglavlju 6.1.1. Radno pamćenje i jezična obrada. 
Na zaslonu je neko vrijeme prikazana jednostavna jednadžba poput "(3 × 1) - 1 =", a sljedeće što sudionik vidi jest znamenka (primjerice, 6), pri čemu mora označiti kućicu točno ili netočno, čime se izjašnjava o tome je li ta znamenka ispravno rješenje prethodno prikazane matematičke jednadžbe. Nakon toga se na zaslonu u trajanju od 1000 ms prikazuje grafem, potom opet jednadžba. Nakon dvije do sedam takvih stavki u kojima sudionik određuje točnost izračuna i pamti grafeme, na zaslonu računala pojavljuje se matrica s dvanaest grafema, a sudionik označava kućice pokraj nekih od njih, pokušavajući se prisjetiti točnoga redoslijeda kojim su bili prikazani (pritiskom tipke miša). Sudioniku je dana mogućnost brisanja prethodno odabranih grafema ako se u međuvremenu predomislio, kao i mogućnost preskakanja jednog ili više grafema u slučaju potpune nemogućnosti prisjećanja. Po dovršenju zadatka prisjećanja, sudionik sam pritiskom tipke miša regulira početak nove serije matematičkih zadataka i prikazivanja grafema. Sudionika se potiče da se jednako usmjeri na rješavanje zadataka i na upamćivanje i prisjećanje grafema. Broj numeričkih zadataka i grafema koje sudionik treba upamtiti prije zadatka prisjećanja varira od dva do sedam, a redoslijed prikaza je slučajan, odnosno broj jednadžbi i grafema ne povećava se linearno od dva prema sedam. Zadatak je programiran na ovaj način kako bi se izbjeglo da sudionik predviđa duljinu niza koji slijedi, odnosno kako ne bi unaprijed znao koliko grafema treba upamtiti (Conway i sur., 2005). Sudionik nije obaviješten je li njegov/njezin odgovor točan, ali nakon zadatka prisjećanja pružena mu/joj je povratna informacija o izvedbi koja se odnosi na broj točno upamćenih grafema i postotak točno riješenih matematičkih zadataka.

Zadatku prethodi kratko uvježbavanje pojedinačnih dijelova. Sudionik najprije uvježbava izolirane zadatke upamćivanja grafema, potom matematičke zadatke, a na koncu i njihovu kombinaciju, kako bi se pripremio na ono što će se u konačnici od njega/nje tražiti. Prilikom uvježbavanja matematičkih zadataka program računa prosječno vrijeme koje je sudioniku potrebno za njihovo rješavanje. Ako osoba u narednim zadatcima prekorači svoje prosječno vrijeme, računalo automatski prikazuje grafem, preskačući dio s odabirom točno/netočno, što se bilježi kao matematička pogreška.

Ukupni brojčani rezultat raspona radnoga pamćenja računa se automatski, jer je program unaprijed programiran na sljedeći način: 1) iz analize se isključuju osobe čija je točnost u rješavanju matematičkih zadataka ispod $85 \%$; te 2) računa se prosječni udio ispravno upamćenih stavki unutar nizova, a ne apsolutne vrijednosti (Conway i sur., 2005; Foster i sur., 2015). Primjerice, ako osoba od tri grafema u nizu točno upamti dva, apsolutni bi izračun to bilježio kao 0 jer niz nije u potpunosti točan. Budući da ovaj program uprosječuje rezultate, to se računa kao parcijalni rezultat 2. Parcijalni je rezultat reprezentativniji i manje strog, a uvijek će biti ili jednak ili viši od apsolutnoga (za 
detaljniju raspravu vidi Conway i sur., 2005). Ukupni se mogući rezultat, odnosno raspon, kreće od 0 do 75 .

Na Slici 4 prikazana je prethodno opisana struktura složenoga zadatka raspona radnoga pamćenja pri računanju (Matić i Palmović, 2018).

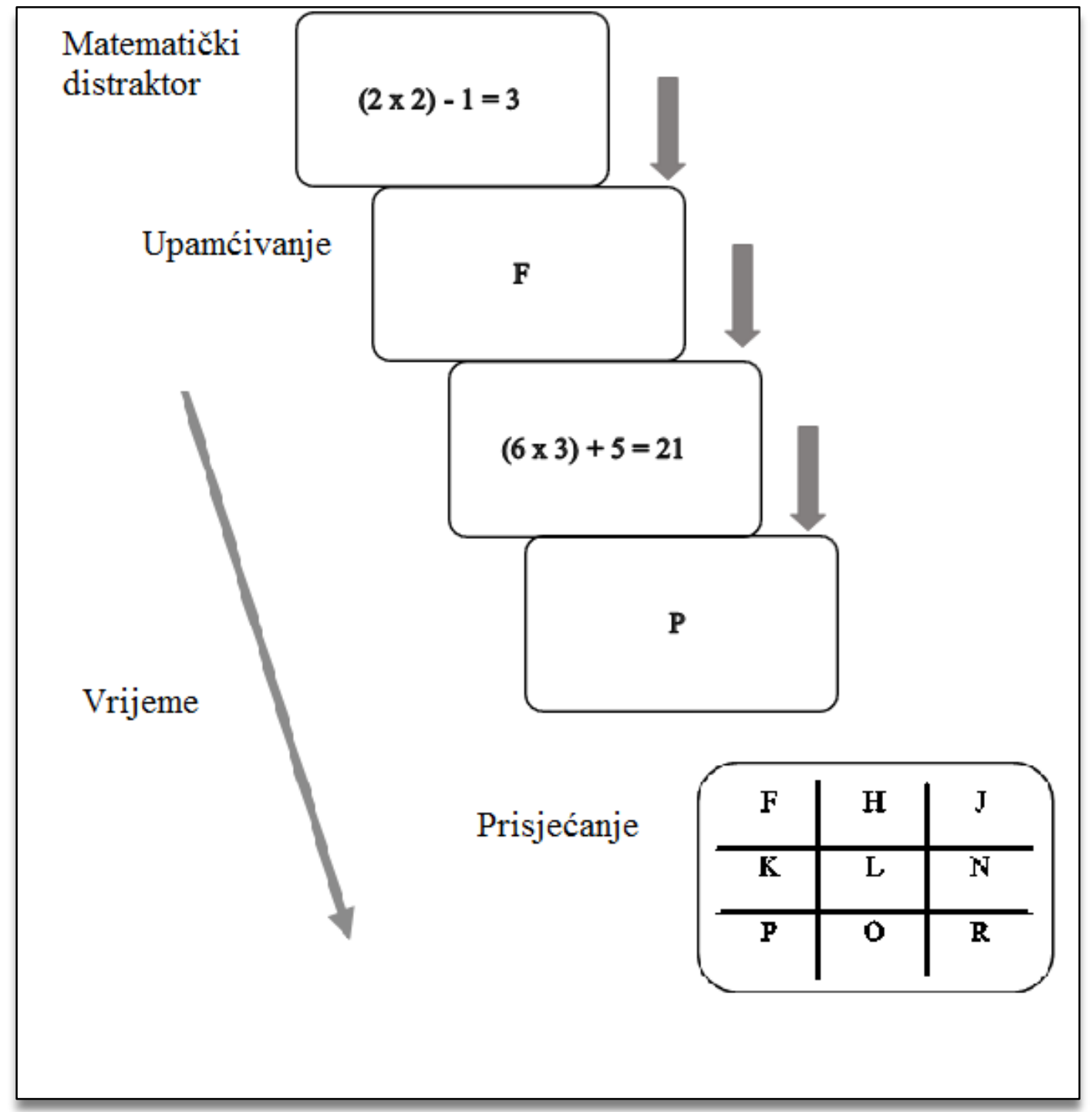

Slika 4. Prikaz strukture složenoga zadatka raspona radnoga pamćenja pri računanju. 


\subsubsection{Postupak}

Ispitivanja su se provodila individualno, u prostorijama Laboratorija za psiholingvistička istraživanja Odsjeka za logopediju Sveučilišta u Zagrebu. Svaki je sudionik najprije potpisao obavijesni pristanak u kojem mu se jamčila anonimnost. Kako sudionici ne bi potpuno proniknuli u svrhu i predmet istraživanja (što bi moglo utjecati na način odgovaranja i rezultate), objasnio im se širi cilj istraživanja. Neki su sudionici najprije rješavali upitnik prosudbe, a neki su započeli sa složenim zadatkom za procjenu raspona radnoga pamćenja. Prije ispunjavanja upitnika svakome je dana kratka uputa da rečenice čitaju u sebi tako da ih razumiju te da nastoje zaokružiti ono što im se prvo nametne kao odgovor. Po završetku ispitivanja dana im je i neobavezna mogućnost da elektroničkom poštom pošalju iskustva i dojmove s istraživanja, kako bi se neizravno prikupili i kvalitativni podatci o osjećaju izvornoga govornika.

\subsubsection{Obrada podataka i analiza rezultata}

\subsubsection{Upitnik prosudbe}

Mjere upotrijebljene pri obradi podataka u upitniku prosudbe bili su odgovori na pitanja kojima se provjeravao odabir antecedenta odnosne zamjenice. Bilježili su se i kodirali svi odgovori, a rezultati su izraženi u postotcima s obzirom na eksperimentalne uvjete (genitivna dopuna i prijedložno-padežni izraz) i pojedinačne odgovore sudionika. U slučaju da je sudionik mijenjao svoj prvi odgovor, u analizu je uvršten onaj prvi.

\subsubsection{Raspon radnoga pamćenja pri računanju}

Ukupni rezultat raspona radnoga pamćenja (0-75) automatski se računao u programu E-prime. Budući da je svrha ovoga zadatka bila prvenstveno homogenizacija uzorka, postignuće na zadatku raspona radnoga pamćenja bio je uključujući, odnosno isključujući kriterij za sudjelovanje u preostalim dijelovima istraživanja. Za daljnje sudjelovanje nije postojao unaprijed određeni kriterij, tj. granična vrijednost (izv. eng. cut-off) koju je bilo potrebno postići, već je ona ovisila o izvedbi čitave skupine (vidi poglavlje 10.3.1. Uzorak sudionika).

\subsubsection{Osjećaj izvornoga govornika}

Pristigli odgovori sudionika koji su sadržavali relevantne podatke o razlozima odabira jednoga ili drugog antecedenta analizirali su se kvalitativno, a grupirali su se s obzirom na vrstu odgovora kao strukturni, obavijesni, prozodijski i drugi čimbenici. 


\subsection{Prvi eksperiment u stvarnom vremenu}

Eksperimentima u stvarnom vremenu ispituje se automatska razina obrade. Logička pozadina ispitivanja preferencija vezivanja metodama u stvarnom vremenu jest ta da će uvjet i/ili dio rečenice koji je zahtjevniji za obradu biti uzrokom sporijega čitanja ili vraćanja na prethodno pročitane dijelove. Metoda na ovaj način omogućuje izravan uvid u preferencije vezivanja u okviru konstrualne hipoteze i dopuna je upitniku u odgođenom vremenu (vidi poglavlje 7.2. Metode u stvarnom vremenu).

\subsubsection{Uzorak sudionika}

$\mathrm{U}$ ispitivanjima u stvarnom vremenu sudjelovali su sudionici koji su temeljem ispitivanja $u$ prvome dolasku zadovoljili sljedeće preduvjete: 1) uspješno riješen zadatak raspona radnoga pamćenja; 2) ujednačen raspon radnoga pamćenja u odnosu na ostale sudionike; te 3) uredan vid. Zbog sličnosti ispitanih struktura, tj. podražaja u dvjema metodologijama, istraživanje se provodilo s vremenskim odmakom od dva do tri mjeseca u odnosu na prvi dolazak. Od ukupno 97 sudionika iz prvoga dijela istraživanja, njih je 92 uspješno dovršilo zadatak raspona radnoga pamćenja. Naime, petoro (5,2\% uzorka) ih je automatski isključeno iz daljnje analize zbog više pogrešno riješenih numeričkih zadataka (njihova je uspješnost bila manja od 85\%). U Tablici 11 prikazana su ukupna postignuća na zadatku raspona radnoga pamćenja preostalih 92 sudionika.

Tablica 11. Deskriptivna statistika za mjeru raspona radnoga pamćenja.

\begin{tabular}{l|r}
\multicolumn{2}{c}{ Mjera raspona RP } \\
\hline \hline$N$ & 92 \\
\hline Min. - maks. vrijednost (raspon) & $26-74(48)$ \\
\hline Srednja vrijednost (st. devijacija) & $60,53(8,810)$ \\
\hline Varijanca & 77,614 \\
\hline Mjera asimetrije & $-0,724$ \\
(skewness) & 0,251 \\
\hline Mjera zaobljenosti (kurtosis) & 1,193 \\
\cline { 2 - 2 } & 0,498 \\
\hline
\end{tabular}


Najniže je postignuće bilo 26, a najveće 74 (od mogućih 75 bodova) i ona su se rasporedila po normalnoj distribuciji. ${ }^{42}$

Budući da je raspon radnoga pamćenja povezan s jezičnom obradom, a velika individualna odstupanja u opsegu toga raspona mogu utjecati na rezultate istraživanja (Swets i sur., 2007; Traxler, 2007), osobe koje su postigle ekstremno niske (26,8\% uzorka) ili visoke rezultate (10,8\% uzorka) isključene su iz analize. Pridoda li se ovim vrijednostima dio uzorka koji je automatski isključen zbog (ne)rješavanja numeričkih zadataka $(5,2 \%)$ te njih $5 \%$ koji se nije odazvao zbog oštećenja vida, proizlazi da je u istraživanju u stvarnom vremenu (temeljem ranije navedenih isključujućih kriterija) naposljetku sudjelovalo 52,2\% sudionika, odnosno 48 osoba $(\mathrm{M}=13 ; \check{Z}=35)$ ujednačenih sposobnosti upamćivanja i integracije različitih razina jezičnih obavijesti tijekom čitanja (Vasishth i Lewis, 2006).

\subsubsection{Materijali}

Podražaji su bili dvosmislene odnosne rečenice te one rečenice u kojima je modifikacija eksperimentalno kontrolirana na način da se surečenica može odnositi samo na prvu ili samo na drugu imenicu unutar NP. Od ukupno 36 ciljanih rečenica, 18 ih je bilo s genitivnim dopunama, a 18 s prijedložno-padežnim izrazima. Od 18 rečenica po razini faktora, šest ih je bilo dvosmislenih, šest u uvjetu vezivanja na N1 te šest u uvjetu vezivanja na N2. Time su stvorena tri eksperimentalna uvjeta za obje skupine ispitanih struktura koja odgovaraju varijablama u daljnjim analizama (dvosmisleni uvjet, uvjet vezivanja na N1 i uvjet vezivanja na N2). Imenske su se skupine uvijek nalazile u subjektnom položaju, rečenice su bile ujednačene po duljini, a imenice i po čestotnosti. Vezivanje je ostvareno manipulacijom sročnošću u rodu, a sve su imenice imale obilježje neživo. Kako bi se sudionike odvratilo od cilja istraživanja, a ujedno postiglo da čitaju s razumijevanjem, osim 36 ciljanih rečenica uvršten je i jednak broj umetnutih podražaja. Njih su činile dopusne i posljedične rečenice. U ispitivanjima preferencija vezivanja u stvarnom vremenu pokazalo se da količina pitanja nakon ispitnih podražaja, kao i njihova vrsta (odnose li se upravo na ono što se ispituje ili na neki drugi dio rečenice), utječu i na izvedbu sudionika i na same rezultate (Swets i sur., 2008; Christianson i Luke, 2011). Iz toga su razloga pitanja za provjeru razumijevanja uslijedila nakon $12(1 / 3)$ ciljanih rečenica te nakon 12 (1/3) umetnutih podražaja. Kako bi se osiguralo da

\footnotetext{
${ }^{42}$ Vrijednosti mjera asimetrije i zaobljenosti između $-2 \mathrm{i}+2$ zadovoljavaju uvjete normalnosti distribucije (George i Mallery, 2010), što je dodatno potvrđeno i Kolmogorov-Smirnovim testom (K-S Z=0,078; df=91; $p>0,05$ ).
} 
sudionici ne odgovaraju po navici, u polovici je slučajeva prva imenica unutar imenske skupine bila ponuđena kao prvi odgovor, a u polovici kao drugi. Odgovori na pitanja nakon ispitnih podražaja zahtijevali su odabir antecedenta odnosne rečenice, što znači da je zahtjev bio nešto veći u uvjetu potpuno dvosmislenih rečenica nego u uvjetu eksperimentalne kontrole vezivanja na N1 ili N2. Pitanjima nakon umetnutih podražaja provjeravalo se razumijevanje različitih dijelova rečenice. Kako su ti podražaji služili samo kao distraktori od cilja ispitivanja i osiguravali da osobe čitaju s razumijevanjem, odgovori se nisu analizirali. Naposljetku, budući da korpusna istraživanja i eksperimenti u hrvatskome jeziku nisu potvrdili značajan utjecaj vrste relativizatora na tumačenje odnosnih rečenica (Kordić, 1995; Lovrić i Fodor, 2000), u eksperimentu u stvarnom vremenu relativizator je bio morfološki neobilježena veznička riječ što. ${ }^{43}$

\subsubsection{Postupak}

Oba su se eksperimenta $\mathrm{u}$ stvarnom vremenu provodila $\mathrm{u}$ jednom dolasku, $\mathrm{u}$ prostorijama Laboratorija za psiholingvistička istraživanja Odsjeka za logopediju Sveučilišta u Zagrebu. Upotrijebljen je stacionarni uređaj za praćenje pokreta očiju (SMI Hi-Speed View 500), a ispitivanje se provodilo individualno, s vremenskim odmakom od dva do tri mjeseca u odnosu na prvi dolazak. Svim su sudionicima nasumično prikazani svi podražaji u svim uvjetima, kao i umetnuti podražaji. Prethodno su im dane upute da rečenice čitaju u sebi tako da ih razumiju te da što točnije odgovaraju na nasumično postavljena pitanja. Nakon čitanja sudionici su sami pritiskom tipke miša kontrolirali završetak prikaza postojećega podražaja te pojavu novog podražaja ili pitanja. Svako je ispitivanje trajalo oko 30 minuta. Slika 5 sažeti je grafički prikaz strukture eksperimenta u stvarnom vremenu, a Slika 6 prikazuje sam postupak ispitivanja.

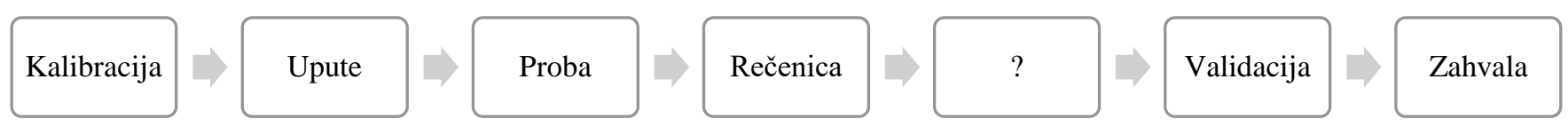

Slika 5. Sažeti prikaz strukture eksperimenta u stvarnom vremenu.

\footnotetext{
${ }^{43}$ Kako je opisano u prethodnim poglavljima, dostupnost morfoloških obavijesti na više mjesta u rečenici valja izbjegavati iz metodoloških razloga.
} 


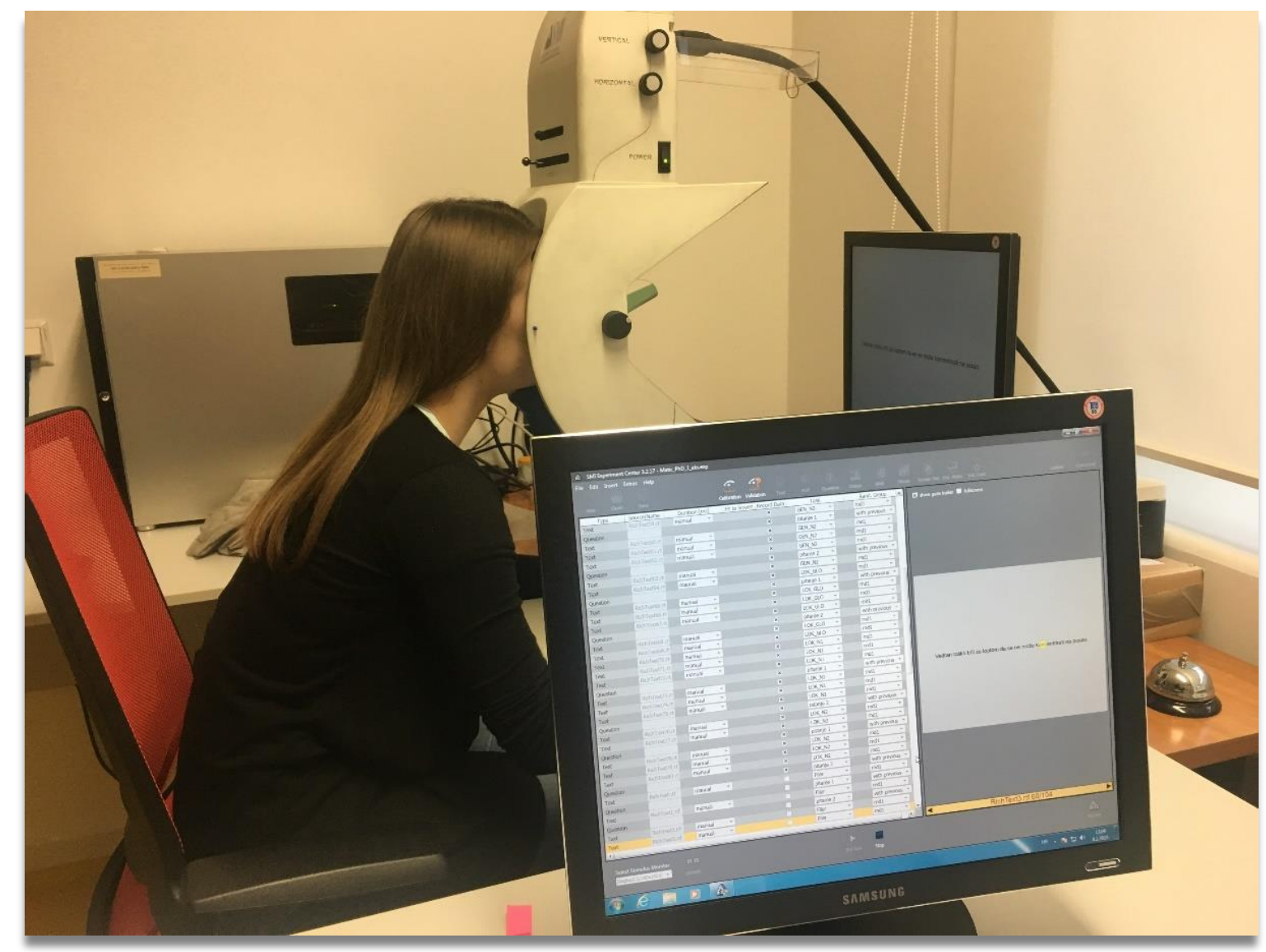

Slika 6. Prikaz ispitivanja u stvarnom vremenu.

\subsubsection{Obrada podataka i analiza rezultata}

Mjere upotrijebljene pri obradi podatka temeljile su se na vremenu čitanja rečenice i prethodno utvrđenih regija interesa, kao i na broju fiksacija te vraćanja pogleda na te dvije regije. Mjere, a ujedno i zavisne varijable istraživanja te njihova operacionalizacija, prikazane su u nastavku (Tablica 12). U prvome je stupcu naveden naziv mjere, a u drugome njezin opis. 
Tablica 12. Prikaz mjera pokreta oka (zavisnih varijabli) i njihova operacionalizacija.

\begin{tabular}{|c|c|}
\hline $\begin{array}{c}\text { Mjera-zavisna } \\
\text { varijabla }\end{array}$ & Opis \\
\hline $\begin{array}{l}\text { Ukupno vrijeme } \\
\text { čitanja (ms) }\end{array}$ & $\begin{array}{l}\text { - mjera ukupnog trajanja čitanja cijele rečenice i jedna od najvažnijih mjera } \\
\text { kojima se može proniknuti u vremenske parametre obrade } \\
\text { - uključuje trajanje fiksacija, ali i trajanje skokovitih sakada i ostalih pokreta } \\
\text { tijekom kojih čitatelj ne izvlači nužno obavijesti iz teksta }\end{array}$ \\
\hline $\begin{array}{l}\text { Ukupno trajanje } \\
\text { fiksacija (ms) }\end{array}$ & $\begin{array}{l}\text { - mjera koja podrazumijeva zbroj fiksacija (u cijeloj rečenici ili prethodno } \\
\text { utvrđenoj regiji interesa), a uključuje trajanje prve fiksacije, kao i trajanje svih } \\
\text { naknadnih do kojih dolazi prilikom vraćanja (regresivnih pokreta oka) na već } \\
\text { pročitane dijelove rečenice } \\
\text { - dulje trajanje svih fiksacija, odnosno produljeno vrijeme čitanja određenoga } \\
\text { dijela rečenice, znakom je većega kognitivnog napora i teškoća u obradi, } \\
\text { primjerice teškoća dohvaćanja strukturnih ili značenjskih obavijesti tijekom } \\
\text { čitanja (Holmqvist i sur., 2011) }\end{array}$ \\
\hline $\begin{array}{l}\text { Prvi prijelaz } \\
\text { (izv. eng. first } \\
\text { pass; ms) }\end{array}$ & $\begin{array}{l}\text { - mjera ukupnoga trajanja svih fiksacija u regiji interesa prije nego ju oko } \\
\text { napusti uslijed sakade u smjeru čitanja ili regresije na prethodno fiksirano } \\
\text { područje } \\
\text { - obuhvaća prvu fiksaciju, kao i trajanje svih naknadnih do kojih dolazi u tom } \\
\text { području interesa, ali prije nego oko fiksira sljedeće područje } \\
\text { - jedna od najpouzdanijih mjera u istraživanjima jezične obrade posredstvom } \\
\text { čitanja jer predstavlja važnu etapu u procesu integracije jezičnih obavijesti, } \\
\text { kako na leksičkoj, tako i na sintaktičkoj razini }\end{array}$ \\
\hline $\begin{array}{l}\text { Broj fiksacija u } \\
\text { regiji interesa }(N)\end{array}$ & $\begin{array}{l}\text { - mjera koja pokazuje ukupan broj fiksacija u području interesa i upućuje na } \\
\text { potrebu za višestrukim čitanjem određenih dijelova uslijed teškoća u } \\
\text { inicijalnom dohvaćanju obavijesti, tj. općenito teškoća obrade }\end{array}$ \\
\hline $\begin{array}{l}\text { Broj regresivnih } \\
\text { pokreta oka u } \\
\text { regiju interesa }(N)\end{array}$ & - mjera koja odražava vraćanje na već pročitano uslijed teškoća obrade \\
\hline
\end{tabular}


Navedene su se mjere promatrale na cijeloj rečenici te na prethodno utvrđenim regijama interesa: imenska skupina i mjesto razrješenja dvosmislenosti. Vidi primjer u nastavku (uvjet vezivanja na $\mathrm{N} 2$ ):

(1) Festival čokolade / što / (2) je proslavila zemlju / trenutno je / na svim vijestima.

Podatci su prikupljeni i obrađeni u programu SMI BeGaze te kasnije statistički analizirani pomoću ANOVA-e s ponovljenim mjerenjima i $t$-testom. Prije provedbe statističkih testova provjerena je normalnost distribucije svih promatranih mjera.

Većina je mjera zadovoljila uvjete normalnosti distribucije (mjere asimetrije i zaobljenosti između $-2 \mathrm{i}+2$ (George i Mallery, 2010) te K-S test $p>0,05)$, stoga su se u analizama koristile parametrijske statističke metode. 


\subsection{Drugi eksperiment u stvarnom vremenu}

Budući da su isti sudionici $(N=48)$ sudjelovali u oba ispitivanja u stvarnom vremenu te da su postupak ispitivanja i mjere uključene u daljnju analizu jednake u tim dvama eksperimentima, opisat će se samo materijali (podražaji, tj. rečenice) u trećem eksperimentu.

\subsubsection{Materijali}

I u ovom su eksperimentu podražaji bili dvosmislene odnosne rečenice $\mathrm{i}$ rečenice $\mathrm{s}$ eksperimentalnom kontrolom modifikacije prve ili druge imenice unutar imenske skupine, čime su ponovno osigurana tri eksperimentalna uvjeta za obje skupine ispitanih struktura (dvosmisleni uvjet, uvjet vezivanja na N1 i uvjet vezivanja na N2). Od ukupno 36 ciljanih rečenica, u njih 18 odnosna se surečenica odnosila na imenicu s obilježjem živo, a u njih 18 na imenicu s obilježjem neživo. Vezivanje je na ovaj način ostvareno manipulacijom značenjskom prihvatljivošću. Osim 36 ciljanih rečenica, uvršten je i jednak broj umetnutih podražaja koje su činile vremenske i uzročne rečenice. Omjer je pitanja nakon ispitnih i umetnutih podražaja, kao i položaj ponuđenih odgovora, slijedio jednaku logiku kao i u prethodno opisanom eksperimentu. 


\section{REZULTATI I RASPRAVA}

Ovaj je dio rada organiziran na sljedeći način: od poglavlja 11.1. Rezultati ispitivanja preferencija u odgođenom vremenu do poglavlja 11.4. Usporedba obrade dvosmislenih $i$ nedvosmislenih rečenica predstavljeni su kvantitativni rezultati svih provedenih eksperimenata te kvalitativna analiza izjava sudionika, dok je u poglavlju 11.5. Spoznaje u općem psiholingvističkom i jezično-specifičnom kontekstu izložena opća rasprava i pružen osvrt na sve dobivene rezultate koji su dovedeni u vezu s ishodišnim modelom i rezultatima prethodnih istraživanja.

\subsection{Rezultati ispitivanja preferencija u odgođenom vremenu}

Ispitivanjem u odgođenom vremenu ispituju se konačne preferencije govornika jezika. Konstrualna hipoteza predviđa razlike u obradi odnosnih rečenica ovisno o tome jesu li imenice koje prethode relativizatoru u genitivnim dopunama ili su dijelovima prijedložno-padežnog izraza, tj. povezane prijedlogom koji ima mogućnost tematskog označavanja. Radi provjere te postavke u nastavku iznosimo prosječne postotke u kojima su sudionici istraživanja u prvome dolasku (N=97) za antecedenta odnosne surečenice odabirali prvu imenicu (N1 naspram N2) unutar složene NP. Rezultati će se, osim brojčano, prikazati i grafički (Slike 7-9). Najprije će se prikazati prosječni postotci odabira N1 za sve rečenice s genitivnim dopunama i sve rečenice s prijedložno-padežnim izrazima među sudionicima istraživanja, bez uvida u pojedinačne strukture. Daljnji će prikazi omogućiti podrobniji uvid u postotak odabira N1 upravo s obzirom na značenjske čimbenike u pojedinim strukturama, posebice onima u kojima su imenske skupine u genitivnim dopunama. Razlog takvom analitičkom pristupu leži u činjenici da konstrualna hipoteza predviđa međujezične i unutarjezične razlike u preferencijama vezivanja s obzirom na načine izražavanja odnosa ostvarenih prvenstveno genitivnim dopunama u jeziku. Osim toga, ti su odnosi posebno složeni u hrvatskome, stoga je moguće da sam način obrade varira ovisno o tome što se njima izražava (vidi poglavlje 5.3. Genitivne dopune u hrvatskome). Prosječni postotci odabira N1 vrlo su visoki, što upućuje na razmjerno visoke preferencije vezivanja na prvi antecedent u obama uvjetima: prosječno 70,3\% odabira N1 u besprijedložnim genitivnim dopunama (GD) i čak $81,1 \%$ odabira N1 u prijedložno-padežnim izrazima (PPI) (Slika 7). 


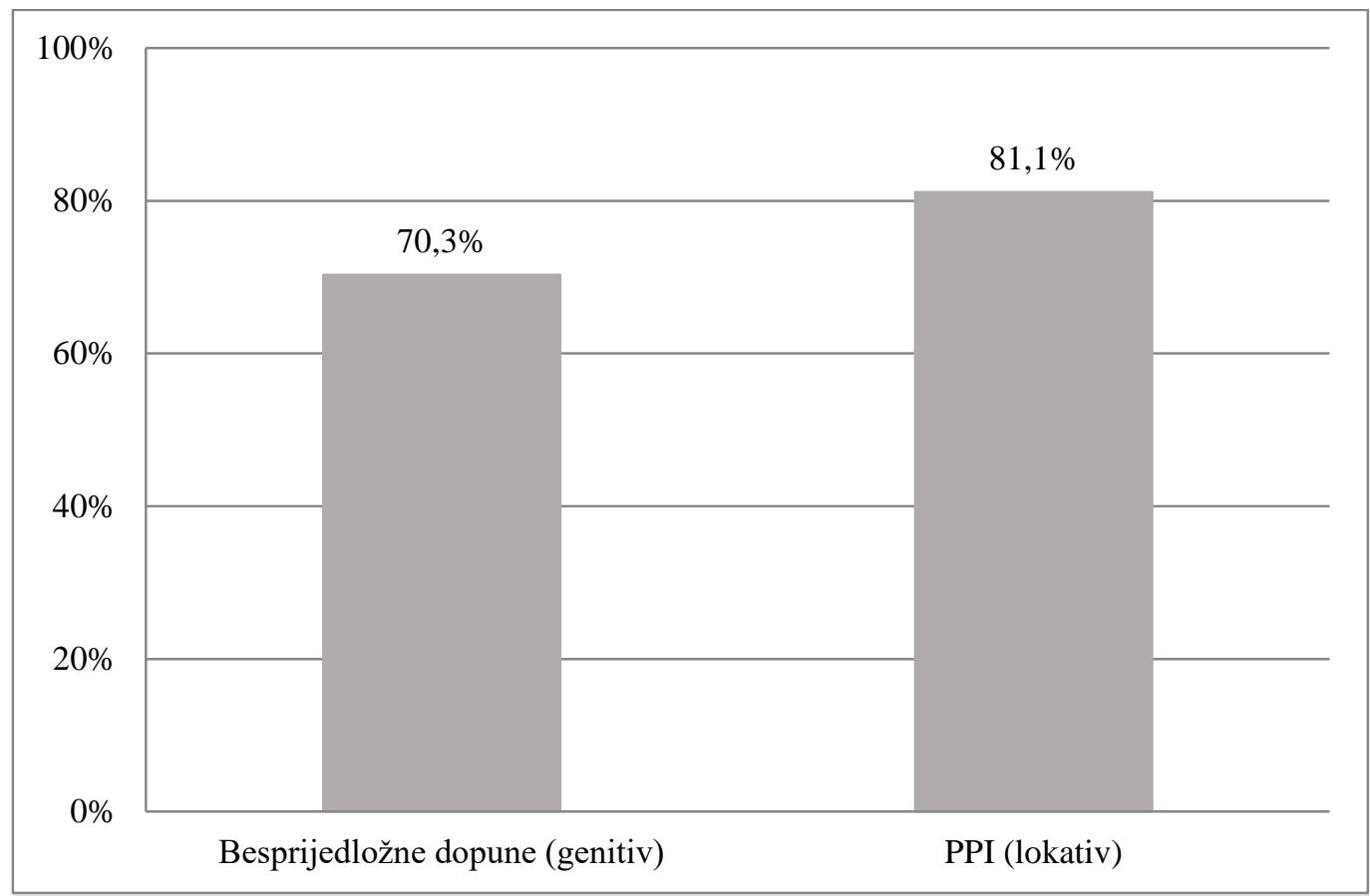

Slika 7. Prosječni postotci vezivanja na N1 u dvama uvjetima.

Iako su preferencije vezivanja na $\mathrm{N} 1 \mathrm{u}$ rečenicama $\mathrm{u}$ kojima relativizatoru prethode imenice $\mathrm{u}$ genitivnim odnosima u skladu s konstrualnom hipotezom, ovako visoke preferencije prema N1 u prijedložnom uvjetu u suprotnosti su s njezinim predviđanjima o mogućnosti promjene fokusa pod utjecajem prijedloga.

Radi statističke provjere pretpostavke o postojanju razlika u tumačenju rečenica s obzirom na vrstu imenske skupine, proveden je i $t$-test za izračunavanje razlika između proporcija kod skupina nezavisnih uzoraka. Ovaj se test smatra primjerenim u slučajevima u kojima se promatra isključivo frekvencija neke pojave, odnosno kada se analiziraju razlike između proporcija pojavljivanja određene pojave te se utvrđuje njihova značajnost. Mjereni su rezultati stoga izraženi u frekvencijama i proporcijama davanja odgovora N1 za svakog sudionika po uvjetu, a proporcije su potom uvrštene u formulu za izračunavanje razlika između proporcija (Petz, 2012: 182). Ako su uzorci dovoljno veliki, a vrijednosti koje se uvrštavaju u formulu nisu ekstremno niske ili visoke, razlika među proporcijama smatra se značajnom na razini 5\%, odnosno ako je dobivena vrijednost $t$ veća od $1,96(t>1,96 ; p<0,05)$.

$\mathrm{Na}$ temelju provedenih postupaka i navedenih preduvjeta nije utvrđena statistički značajna razlika u frekvencijama odgovora, odnosno u preferencijama vezivanja u dvama ispitanim uvjetima (besprijedložna GD i PPI s prijedlogom lokacije; $t=0,565$ ). 
Nadalje, slijedeći pristup psiholingvističkom istraživanju koji su uveli Gilboy i sur. (1995), i u ovom su ispitivanju strukture $\mathrm{s}$ genitivnim dopunama podijeljene u nekoliko podskupina $\mathrm{s}$ obzirom na svoja značenjska obilježja. Gilboy i sur. (1995) su, naime, među prvima razmotrili različite mogućnosti izražavanja odnosa imenica u genitivnim dopunama i onih povezanih prijedlogom te ih doveli u vezu s odgovorima sudionika istraživanja. Takav je analitički pristup važan jer se tek razmatranjem obilježja struktura i njihova mogućeg utjecaja na obradu mogu donijeti valjani zaključci o preferencijama govornika, sintaktičkoj obradi i unutarjezičnim čimbenicima koji ju uvjetuju.

$\mathrm{U}$ provedenom upitniku prosudbe u većini su rečenica obje imenice u genitivnim dopunama imale obilježje neživo i bile su u kontaktnom odnosu, dok su u preostalim ispitanim rečenicama imenice imale obilježje živo i bile su u distaktnom odnosu. U potonjem je uvjetu druga imenica uvedena atributom (pridjevom) ili posvojnom zamjenicom, u skladu s pravilima tvorbe tih vrsta genitivnih dopuna u hrvatskome. Postotak odabira N1 s obzirom na podskupinu genitivnih dopuna kojoj pripadaju pojedine rečenice, tj. s obzirom na obilježje živosti antecedenata, još jednom upućuje na prevladavajuću preferenciju vezivanja na prvu imenicu. Tomu je tako i u uvjetu u kojem su imenice s obilježjem živo u distaktnom odnosu (N1=66\%), i u uvjetu u kojem su imenice s obilježjem neživo u kontaktnom odnosu $(\mathrm{N} 1=73,2 \%)$ (Slika 8).

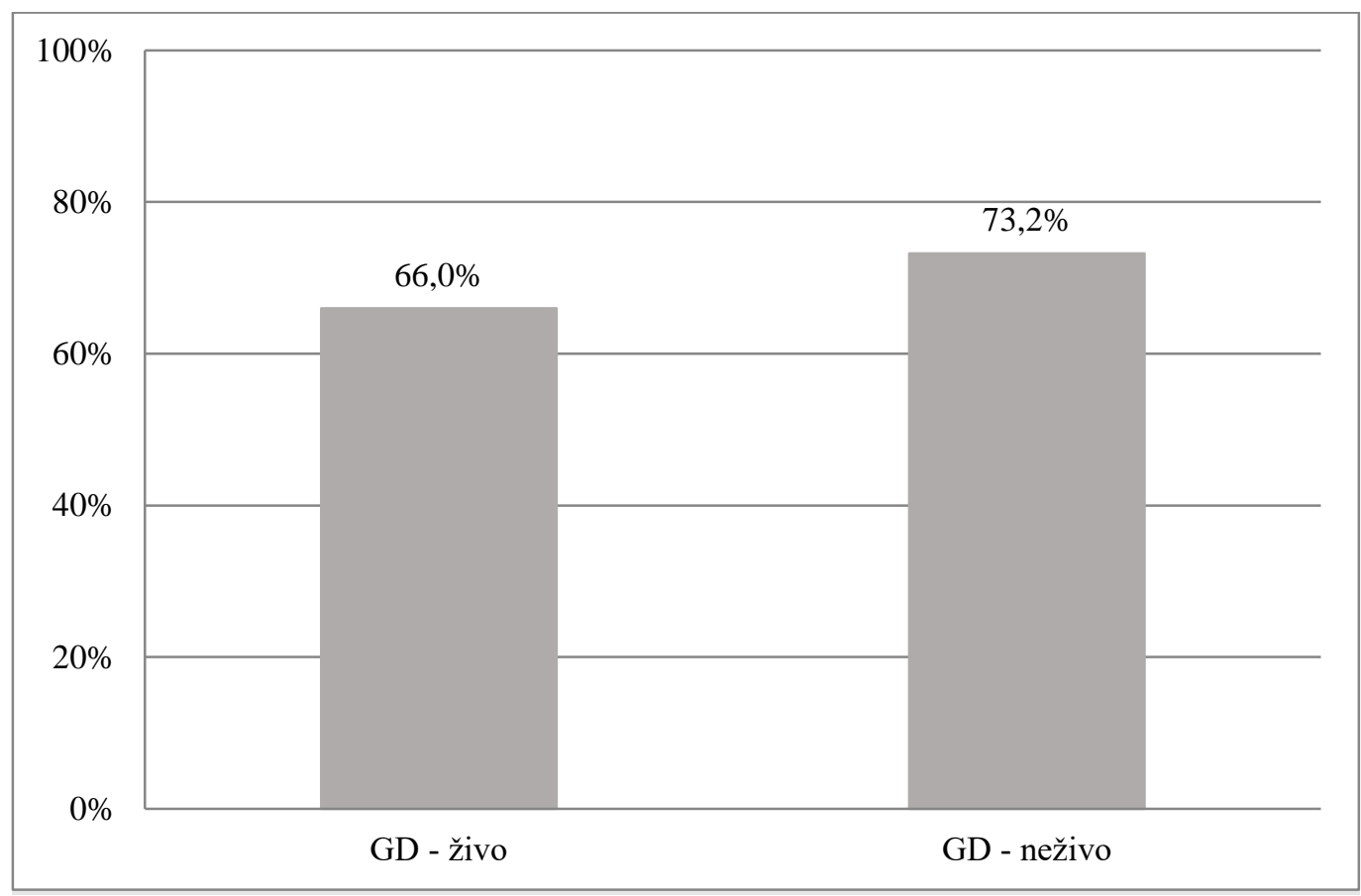

Slika 8. Postotak odabira N1 s obzirom na obilježje živosti antecedenata u genitivnoj dopuni. 
Preferencija je prema prvoj imenici ipak veća u potonjem uvjetu (drugi stupac na Slici 8), u kojem su imenice u kontaktnom odnosu (primjerice, Tvornica čokolade koja je proslavila zemlju trenutno je na svim vijestima; preostale primjere vidi u Prilozima). Naime, moguće je da govornici upravo zbog kontaktnog odnosa ovakve strukture obrađuju kao jednu sintagmatsku cjelinu.

U uvjetu u kojem obje imenice u NP imaju obilježje živo distaktnost je uzrokovana neglagolskim članom glavne rečenice koji je podređen antecedentu, što i jest u skladu s tvorbom takve vrste genitivnih dopuna u hrvatskome. Prema Kordić (1995) i Kuna (2003) ove genitivne dopune (ili kakav drugi tip odredbe) i dalje pripadaju istoj nominalnoj sintagmi.

Rezultati upitnika, odnosno prevladavajući odgovori sudionika ovoga istraživanja potvrđuju da se imenice u složenoj imenskoj skupini obrađuju kao da su dijelom iste sintagme te da se ono što u rečenici slijedi vezuje na prvu imenicu (prvi stupac na Slici 8). Potpuno suprotno, većina modularnih modela sintaktičke obrade spomenutih u uvodu zagovara univerzalne principe lokalnosti, tj. vezivanje na drugu imenicu u složenoj imenskoj skupini, posebice ako su imenice u distaknom odnosu. Takve se preferencije objašnjavaju manjim troškovima obrade za govornike jezika (vidi poglavlje 2.1. Modularni (serijalni) modeli).

Iako je u mnogim jezicima zabilježena preferencija vezivanja odnosne surečenice na drugu imenicu unutar složene imenske skupine, čini se da govornici hrvatskoga ipak u većem omjeru drugu imenicu smatraju podređenom prvoj te čitave genitivne dopune obrađuju kao jednu sintagmu u kojoj je prva imenica glavom. ${ }^{44}$

Na tumačenje rečenice utječe i vrsta distaktnog odnosa, tj. način obilježavanja druge imenice $u$ složenoj imenskoj skupini. Razmatrajući čimbenike koji mogu utjecati na preferencije vezivanja u odnosnim rečenicama, Frazier i Clifton (1997) spominju mogući utjecaj referencijalnog označavanja druge imenice na vezivanje i način na koji govornici jezika tumače rečenicu. Kako se u nekim jezicima posvojnost češće izražava pridjevskim oblikom, izražavanje posvojnosti (bes)prijedložnom genitivnom dopunom zahtijevat će drugačija pravila, poput obilježavanja druge imenice pridjevom ili zamjenicom u hrvatskome. Gilboy i sur. (1995), Frazier i Clifton (1997) te Hemforth i sur. (2000a) među onima su koji su primijetili tendenciju porasta preferencija prema N2 kada je ona u imenskoj skupini posebno označena, to

\footnotetext{
${ }^{44}$ Teorijska razmatranja o odnosu glave i dopune vidi u Matasović (2000), Van Valin (2001), Kuna (2003) itd., kao i u poglavljima 11.5. Spoznaje u općem psiholingvističkom i jezično-specifičnom kontekstu i 13. Znanstveni doprinos i ograničenja istraživanja.
} 
jest kada je obilježena determinatorom. Zaključuju kako će upravo određeni član, pridjev i zamjenica s takvom funkcijom označavanja utjecati na prebacivanje fokusa govornika na drugu imenicu u složenoj NP te će se posljedično promijeniti njegova preferencija.

Suprotno predviđanjima, sudionici su ovoga istraživanja i u tom uvjetu iskazali preferenciju prema prvoj imenici. Preferencije su ipak nešto manje izražene u uvjetu označavanja druge imenice pridjevom $(\mathrm{N} 1=55,2 \%)$ negoli zamjenicom $(\mathrm{N} 1=76,8 \%)$ (Slika 9 i Tablica 13).

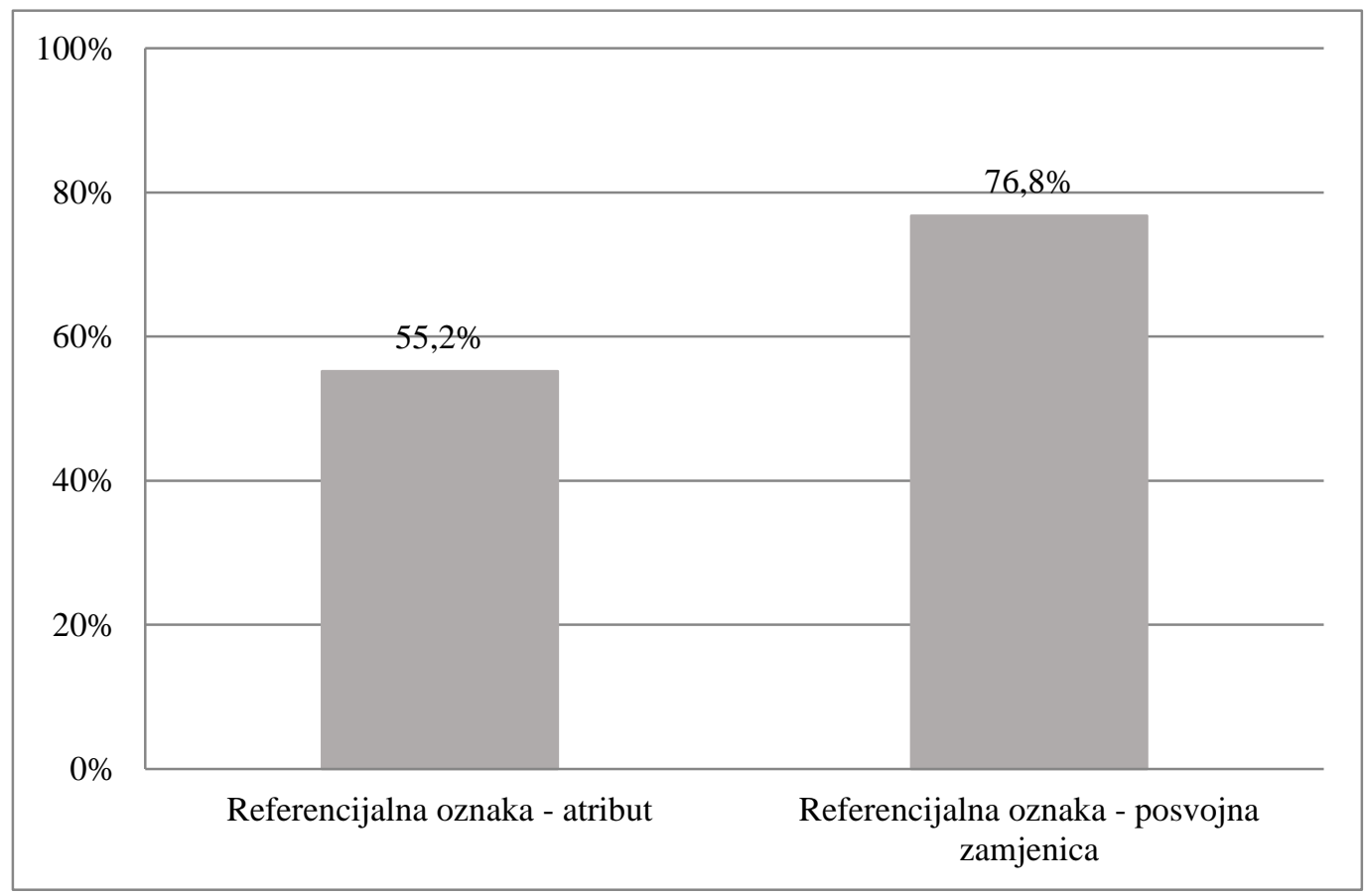

Slika 9. Postotak odabira N1 s obzirom na obilježje referencijalnosti antecedenta u genitivnoj dopuni.

U hrvatskome se jeziku atribucijom (pridjevima, zamjenicama, neodređenom riječju) precizira sadržaj nekog pojma (vidi Kordić, 1995), a rezultati provedenog upitnika pokazuju kako je moguće da se upravo preciziranjem sadržaja unutar određene strukture govornikova pažnja može preusmjeriti, iako ne i jednako snažno. Rezultati prikupljeni metodom upitnika naime pokazuju da je pridjev nešto snažnije sredstvo preciziranja sadržaja negoli je to posvojna zamjenica.

Sagledavajući prosječne rezultate, odnosno prosječne postotke vezivanja u uvjetima različitog označavanja N2 u genitivnoj dopuni, zamijećeno je da će govornici hrvatskoga rečenicu 
(10) Sin bogatog trenera koji ima tešku bolest glavna je tema svake kave.

u prosjeku češće tumačiti na način da trener pati od teške bolesti. Identičnu bi surečenicu (koji ima tešku bolest) nakon imenske skupine sin moga trenera nešto češće vezivali na sina (vidi Tablicu 13). To je donekle samorazumljvo jer pridjevom opisujemo i označavamo specifična svojstva nekog referenta, razlikujući ga tako od kojeg drugog, dok zamjenicom samo preciziramo da se radi o momu, tvomu, njegovomu.

U Tablici 13 sumirani su rezultati utemeljeni na odgovorima sudionika koji su ispunjavali upitnik prosudbe $(N=97)$. Ovaj je tablični prikaz nastao po uzoru na onaj Gilboy i njezinih suradnika (1995). Primjeri su stoga grupirani s obzirom na vrstu imenske skupine koja prethodi odnosnoj surečenici, a označena je i vrsta toga odnosa s obzirom na značenje sadržano u imenskoj skupini. U pretposljednjem je stupcu primjer genitivne dopune ili prijedložnopadežnog izraza iz upitnika, dok posljednji stupac prikazuje postotak u kojem su sudionici kao antecedenta odredili prvu imenicu unutar imenske skupine.

Tablica 13. Primjeri ispitnih podražaja i njihova podjela s obzirom na vrstu NP i značenjske odnose imenica unutar NP koja prethodi odnosnoj zamjenici.

\begin{tabular}{llll} 
Skupina & Strukturno-značenjska obilježja & Primjer & $\mathbf{\%}$ \\
\hline \hline $\begin{array}{l}\text { Genitivna dopuna; } \\
\text { kontaktni odnos }\end{array}$ & Nž: genitiv cjeline & krov vrtića & $77,3 \%$ \\
\cline { 2 - 4 } & Nž: objasnidbeni genitiv & naslov članka & $37,1 \%$ \\
\hline Ukupno: NP u kontaktnom odnosu (neživo) & & $\mathbf{7 3 , 2 \%}$ \\
\hline $\begin{array}{l}\text { Genitivna dopuna; } \\
\text { distaktni odnos } \\
\text { (posvojnost) }\end{array}$ & \begin{tabular}{l} 
Ž: referencijalna oznaka pridjev \\
\cline { 2 - 4 } Ž: referencijalna oznaka posvojna
\end{tabular} & sin bogatog trenera & $55,2 \%$ \\
\hline Ukupno: NP u distaktnom onašeg šefa & $76,8 \%$ \\
\hline $\begin{array}{l}\text { Prijedložno-padežni } \\
\text { izrazi (na/u) }\end{array}$ & Nž: statična lokacija & most u gradu & $\mathbf{6 6 , 0 \%}$ \\
\hline Ukupno: Prijedložno-padežni izrazi (lokacija) & & $\mathbf{8 1 , 1 \%}$
\end{tabular}

Iz Tablice 13 jasno je vidljiva opća preferencija prema prvoj imenici bez obzira o kojoj je vrsti imenske skupine riječ (genitivna dopuna ili prijedložno-padežni izraz). Taj je zaključak ujedno i najznačajniji budući da se kosi s predviđanjem konstrualne hipoteze o promjeni preferencija pod utjecajem prijedloga koji može uzrokovati promjenu fokusa govornika. Iako 
prevladavajuće, preferencije prema N1 kao glavi imenske skupine u nešto su manjoj mjeri stabilne u sljedećim uvjetima: kada su imenice u distaktnom odnosu naspram kada su u kontaktnom odnosu te kada je $\mathrm{N} 2$ uvedena pridjevom u odnosu na strukture u kojima je uvedena posvojnom zamjenicom. Također se čini da govornici hrvatskoga genitivnu dopunu u kojoj antecedenti imaju obilježje neživo češće tumače kao jednu nedjeljivu cjelinu u kojoj je prva imenica glavom (preferencije iznad 73\%) negoli je to slučaj s genitivnom dopunom u kojoj imaju obilježje živo (preferencije oko 66\%).

Jedini primjer koji odstupa od ostalih jest genitivna dopuna naslov članka. Naime, govornici u tom primjeru u većem broju slučajeva $(62,9 \%)$ smatraju da odnosna surečenica koji je pun neistina modificira imenicu članak (N2) nego naslov (N1). Kako se radi o jednom primjeru, jasnije je i valjanije zaključke teško donositi. Moguće je, primjerice, da su se nakon nekoliko čitanja rečenice sudionici istraživanja odlučili za taj odgovor vođeni činjenicom da je izglednije da je članak pun neistina negoli naslov. ${ }^{45}$

Da promjena preferencija i u hrvatskome ovisi o onome što se izražava imenskom skupinom koja prethodi odnosnoj surečenici pokazalo je i istraživanje Matić (2018). Dobivena je vrlo slična preferencija prema N1 (68,9\%) kao i u ovome istraživanju (70,3\%), ali je u istraživanju iz 2018. godine uz genitivne dopune ispitano tumačenje nekoliko vrsta prijedložno-padežnih izraza s mogućnostima višestrukoga tumačenja: u instrumentalu ( $s$ ) i akuzativu $(z a$ i $n a)$. Zanimljivo, pokazalo se da do promjene preferencije dolazi samo u imenskim skupinama s prijedložno-padežnim izrazima u akuzativu. Preferencije prema N1 za prijedlog $n a$ iznosile su tek $36,1 \%$, a za imenske skupine s prijedlogom za preferencije su bile ujednačene $(51,7 \%$ prema $\mathrm{N} 1, \mathrm{tj} .48,3 \%$ prema N2).

Kako se preferencije u dvama uvjetima (besprijedložna genitivna dopuna i prijedložno-padežni izraz) u ovom istraživanju ne razlikuju značajno - postoji jasna preferencija prema prvoj imenici bez obzira na vrstu imenske skupine - može se zaključiti da u hrvatskome vrijedi generalna preferencija vezivanja na prvu imenicu. Dobiveni je rezultat u skladu s prethodno provedenim istraživanjima u hrvatskome (Lovrić i Fodor, 2000; Lovrić, i sur., 2001; Lovrić, 2003; Matić, 2018), ali detalje o mehanizmima obrade u stvarnom vremenu iznosimo u nastavku.

\footnotetext{
${ }^{45}$ Upravo su zbog slučajeva poput ovoga ispitivanja u stvarnom vremenu metodološki snažnija; omogućavaju uvid u inicijalne mehanizme obrade, a time i u nesvjesne preferencije govornika jezika.
} 


\subsection{Rezultati ispitivanja preferencija u stvarnom vremenu}

Eksperimenti u stvarnom vremenu provedeni su radi stjecanja uvida u vremenski tijek obrade i automatski odgovor sudionika istraživanja, govornika hrvatskoga. Prvim je od dvaju eksperimenata ispitan utjecaj vrste imenske skupine na preferencije vezivanja, to jest na odabir antecedenta, dok je drugim ispitan utjecaj obilježja živosti na preferencije govornika. U nastavku iznosimo rezultate oba eksperimenta.

11.2.1. Utjecaj vrste imenske skupine na preferencije vezivanja (prvi eksperiment)

Statističkom analizom podataka prikupljenih metodom praćenja pokreta očiju (ANOVA s ponovljenim mjerenjima; rmANOVA) za svaku su mjeru u dvjema regijama interesa uspoređena dva faktora:

a) imenska skupina (s dvije razine; genitivna dopuna i prijedložno-padežni izraz) te

b) vrsta vezivanja (s dvije razine; vezivanje na N1 i vezivanje na N2).

Zavisne su varijable bile promatrane mjere (vidi Tablicu 12), a nezavisne promatrani faktori. U nastavku će se prikazati glavni efekti i interakcije za svaku varijablu, a rezultati će se raspraviti u kontekstu iznesenih teorijskih postavki i pretpostavki istraživanja (poglavlje 11.5. Spoznaje u općem psiholingvističkom i jezično-specifičnom kontekstu).

Prosječni je postotak točnih odgovora na pitanja nakon ispitnih podražaja (u uvjetu N1 i N2) u ovom eksperimentu bio vrlo visok. Sudionici $(N=48)$ su uglavnom odgovarali u potpunosti točno (100\%) ili su tek sporadično griješili $(92,3 \%)$, što je dokazom da su čitali $\mathrm{s}$ razumijevanjem i da su se koncentrirali na zadatak. Dvije su osobe na pitanja odgovarale s manje od $85 \%$ točnosti, zbog čega se u ovom eksperimentu njihovi rezultati nisu analizirali. Odgovori na pitanja u uvjetu dvosmislene rečenice upućuju na zanimljivu tendenciju koja je u skladu s preferencijama ustanovljenima upitnikom prosudbe. Od 46, samo je 9 sudionika na pitanja odgovaralo odabirom N2, dok je preostalih 37 u većoj mjeri odabiralo N1. Osim isključivanja podataka dviju sudionica, sve su pojedinačne fiksacije s trajanjem $<80 \mathrm{~ms}$ također isključene iz daljnje analize, iz razloga što osobe u tako kratkom vremenu ne uspijevaju dohvatiti jezične obavijesti iz teksta (Rayner i Pollatsek, 1989).

U Tablici 14 prikazane su srednje vrijednosti svih analiziranih mjera u dvjema regijama interesa za obje vrste vezivanja (vezivanje na N1 i vezivanje na N2) i obje vrste NP koje prethode 
odnosnoj surečenici (genitivne dopune i prijedložno-padežni izrazi). Dulje trajanje fiksacija, njihov veći broj, kao i veći broj regresivnih pokreta oka upućuju na veći obradbeni napor (Liversedge, Paterson i Pickering, 1998; Holmqvist i sur., 2011). Mjere vremenskoga trajanja izražene su u milisekundama (ms), dok su mjere promatranih događaja (izv. eng. events) izražene kao sirove vrijednosti $(N)$.

Tablica 14. Prosječne vrijednosti svih analiziranih mjera u svim uvjetima (prvi eksperiment u stvarnom vremenu).

\begin{tabular}{|c|c|c|c|c|}
\hline & \multicolumn{2}{|c|}{ Genitivna dopuna } & \multicolumn{2}{|c|}{ Prijedložno-padežni izraz } \\
\hline $\begin{array}{c}\text { Mjere ili } \\
\text { zavisne varijable }\end{array}$ & $\begin{array}{c}\text { Regija } \\
\text { NP }\end{array}$ & $\begin{array}{c}\text { Regija } \\
\text { Razrješenje } \\
\text { dvosmislenosti }\end{array}$ & $\begin{array}{c}\text { Regija } \\
\boldsymbol{N P}\end{array}$ & $\begin{array}{c}\text { Regija } \\
\text { Razrješenje } \\
\text { dvosmislenosti }\end{array}$ \\
\hline \multicolumn{5}{|c|}{ Ukupno vrijeme čitanja (ms) } \\
\hline Uvjet Dvosmislena & \multicolumn{2}{|c|}{6053,23} & \multicolumn{2}{|c|}{6651,08} \\
\hline Uvjet N1 & \multicolumn{2}{|c|}{5912,83} & \multicolumn{2}{|c|}{5933,47} \\
\hline Uvjet N2 & \multicolumn{2}{|c|}{6241,28} & \multicolumn{2}{|c|}{6616,16} \\
\hline \multicolumn{5}{|c|}{ Ukupno trajanje fiksacija $(\mathrm{ms})$} \\
\hline Uvjet N1 & 1606,26 & 1431,53 & 1553,22 & 1481,39 \\
\hline Uvjet N2 & 1709,07 & 1609,45 & 1603,35 & 1634,6 \\
\hline \multicolumn{5}{|l|}{ Prvi prijelaz $(m s)$} \\
\hline Uvjet N1 & 864,52 & 670,14 & 814,27 & 707,86 \\
\hline Uvjet N2 & 808,16 & 791,36 & 774,51 & 877,02 \\
\hline \multicolumn{5}{|l|}{ Brojfiksacija $(N)$} \\
\hline Uvjet N1 & 38,57 & 34,93 & 38,7 & 36,07 \\
\hline Uvjet N2 & 42,22 & 40,67 & 38,8 & 39,35 \\
\hline \multicolumn{5}{|c|}{ Broj regresivnih pokreta oka $(N)$} \\
\hline Uvjet N1 & 9,39 & 11,22 & 8,89 & 11,09 \\
\hline Uvjet N2 & 10,35 & 13,07 & 12,83 & 15,02 \\
\hline
\end{tabular}

Već je iz prvog pogleda na vrijednosti u Tablici 14 razvidno da su osobe prosječno više vremena provele čitajući rečenice (i ključne regije interesa) u kojima je ostvareno vezivanje na drugu imenicu unutar NP. Ta se tendencija primjećuje neovisno o vrsti NP koja prethodi odnosnoj 
zamjenici (GD i PPI), što je suprotno predviđanjima konstrualne hipoteze, a u skladu s rezultatima prethodno provedenog eksperimenta u odgođenom vremenu.

S ciljem provjere značajnosti opaženih tendencija, za svaku je regiju i svaku zavisnu varijablu učinjena 2x2 rmANOVA, a razlike su se smatrale značajnima na razini značajnosti od 5\%. Glavni efekti i interakcije dat će odgovor na pitanje postoje li značajne razlike u preferencijama ovisno o ispitanim uvjetima, odnosno u kojim je uvjetima govornicima hrvatskoga obrada otežana.

Značajni su efekti dobiveni na oba faktora, imenska skupina (GD/PPI) i vrsta vezivanja $(\mathrm{N} 1 / \mathrm{N} 2)$, na obje promatrane regije interesa u rečenici. Glavni efekti $(p<0,05)$ za faktor imenska skupina dobiveni su na mjerama broj regresivnih pokreta oka u regiju NP $(\mathrm{F}(1,45)=5,944$; $\left.p=0,019 ; \eta^{2} p=0,117 ; P=0,665\right)$ i prvi prijelaz okom u regiji razrješenja dvosmislenosti $\left(\mathrm{F}(1,45)=5,027 ; p=0,030 ; \eta^{2} p=0,100 ; P=0,593\right)$.

Više je glavnih efekata utvrđeno za faktor vrsta vezivanja. Dobiveni su statistički značajni efekti na mjerama ukupno vrijeme čitanja $\left(\mathrm{F}(1,45)=18,198 ; p=0,000 ; \eta^{2} p=0,288 ; P=0,987\right)$, broj regresivnih pokreta oka u regiju $\mathrm{NP}\left(\mathrm{F}(1,45)=35,414 ; p=0,000 ; \eta^{2} p=0,440 ; P=1,000\right)$, ukupno trajanje fiksacija u regiji razrješenja dvosmislenosti $\left(\mathrm{F}(1,45)=13,676 ; p=0,001 ; \eta^{2} p=0,233\right.$; $P=0,951)$, broj fiksacija u regiji razrješenja dvosmislenosti $(\mathrm{F}(1,45)=25,625 ; p=0,000$; $\left.\eta^{2} p=0,363 ; P=0,999\right)$ i broj regresivnih pokreta oka u regiju razrješenja dvosmislenosti $\left(\mathrm{F}(1,45)=39,199 ; p=0,000 ; \eta^{2} p=0,466 ; P=1,000\right)$. Vrijednosti na mjeri broj fiksacija u regiji NP dostižu graničnu značajnost $(p=0,053)$.

Glavni su efekti na promatranim mjerama (zavisnim varijablama istraživanja) za obje regije i oba promatrana faktora zbog preglednosti prikazani tablično (Tablice 15 i 16) i grafički (Slike $10-15)$.

Tablica 15. Prikaz glavnih efekata na promatranim mjerama (zavisnim varijablama) za faktor imenska skupina; GD/PPI (prvi eksperiment u stvarnom vremenu).

\begin{tabular}{ccccccc} 
Varijabla & Regija & $\boldsymbol{d f}$ & $\boldsymbol{F}$ & $\boldsymbol{p}$ & $\boldsymbol{\eta}^{2} \boldsymbol{p}$ & $\boldsymbol{P}$ \\
\hline $\begin{array}{c}N \text { regresivnih } \\
\text { pokreta oka }\end{array}$ & NP & 1,45 & 5,944 & 0,019 & 0,117 & 0,665 \\
\hline & & & & & \\
\hline Prvi prijelaz & $\begin{array}{c}\text { Razrješenje } \\
\text { dvosmislenosti }\end{array}$ & 1,45 & 5,027 & 0,030 & 0,100 & 0,593 \\
\hline
\end{tabular}


Tablica 16. Prikaz glavnih efekata na promatranim mjerama (zavisnim varijablama) za faktor vrsta vezivanja; N1/N2 (prvi eksperiment u stvarnom vremenu).

\begin{tabular}{|c|c|c|c|c|c|c|}
\hline Varijabla & Regija & $d f$ & $\boldsymbol{F}$ & $p$ & $\eta_{p}^{2}$ & $P$ \\
\hline $\begin{array}{l}\text { Ukupno } \\
\text { vrijeme } \\
\text { čitanja } \\
\end{array}$ & Cijela rečenica & 1,45 & 18,198 & 0,000 & 0,288 & 0,987 \\
\hline $\begin{array}{c}N \text { regresivnih } \\
\text { pokreta oka }\end{array}$ & NP & 1,45 & 35,414 & 0,000 & 0,440 & 1,000 \\
\hline $\begin{array}{l}\text { Ukupno } \\
\text { trajanje } \\
\text { fiksacija }\end{array}$ & Razrješenje & 1,45 & 13,676 & 0,001 & 0,233 & 0,951 \\
\hline$N$ fiksacija & dvosmislenosti & 1,45 & 25,625 & 0,000 & 0,363 & 0,999 \\
\hline $\begin{array}{l}N \text { regresivnih } \\
\text { pokreta oka }\end{array}$ & & 1,45 & 39,199 & 0,000 & 0,466 & 1,000 \\
\hline
\end{tabular}

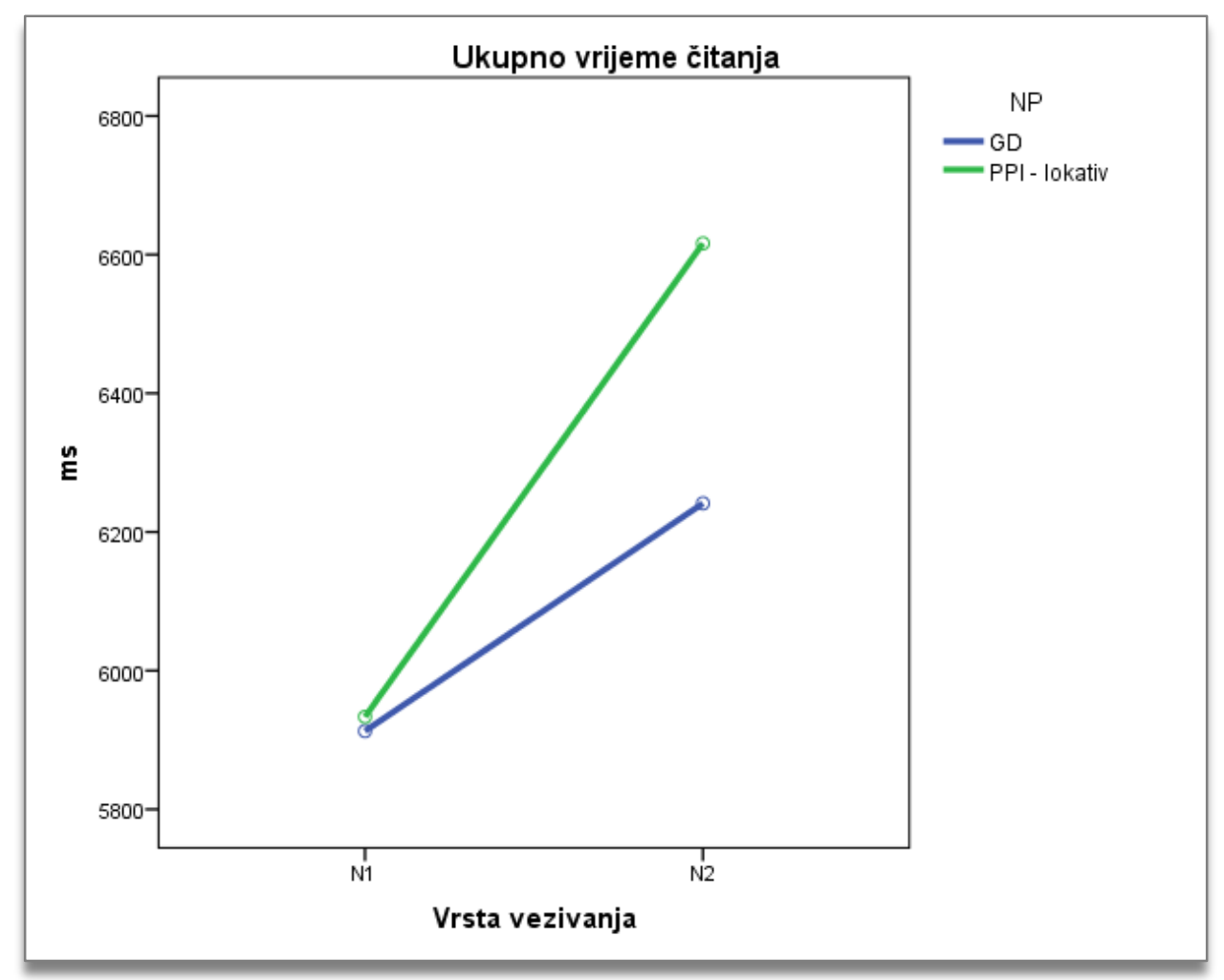

Slika 10. Grafički prikaz glavnih efekata na mjeri ukupno vrijeme čitanja (faktor vrsta vezivanja; N1/N2). 


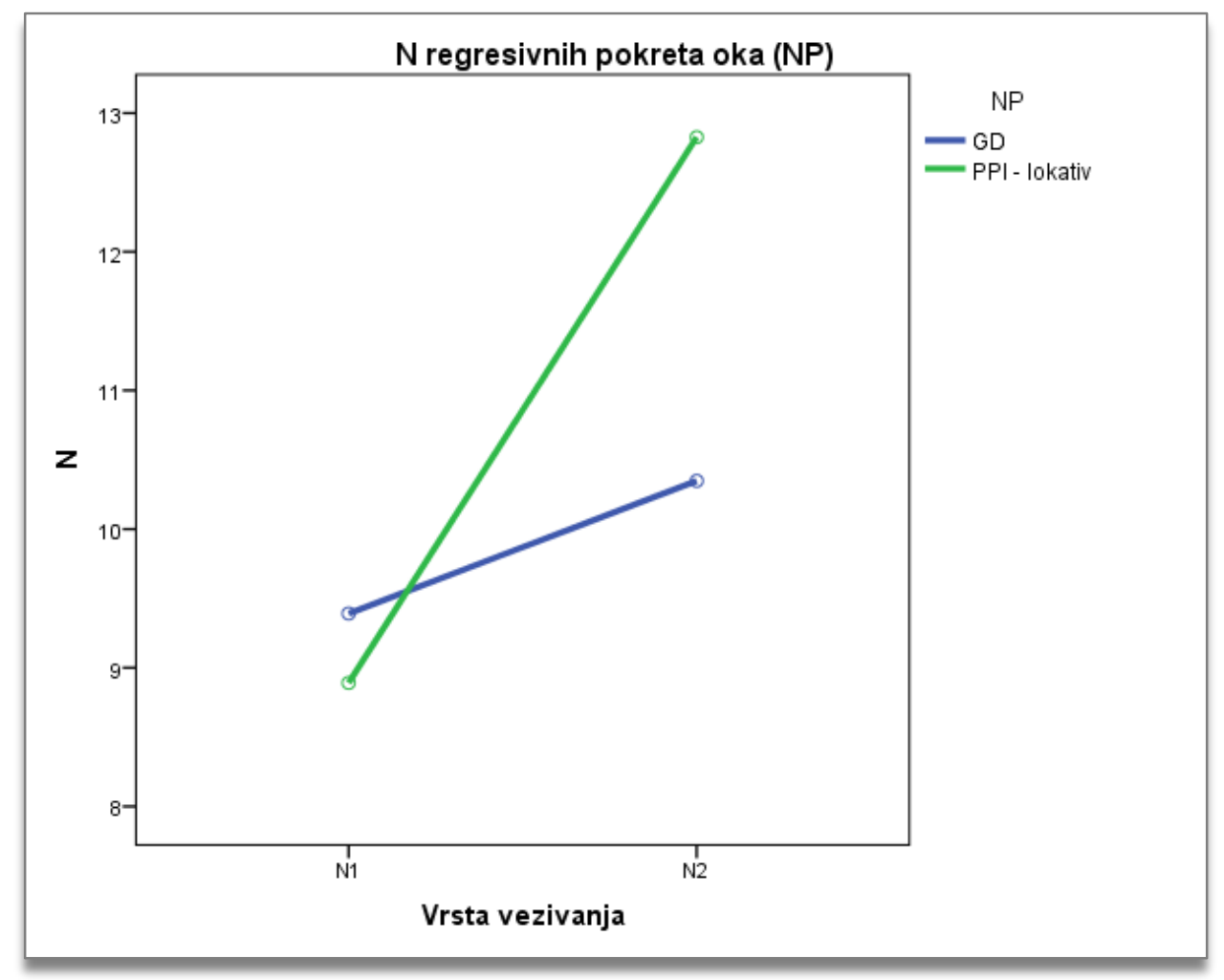

Slika 11. Grafički prikaz glavnih efekata na mjeri $N$ regresivnih pokreta oka u regiju NP (faktor imenska skupina; GD/PPI i vrsta vezivanja; N1/N2).

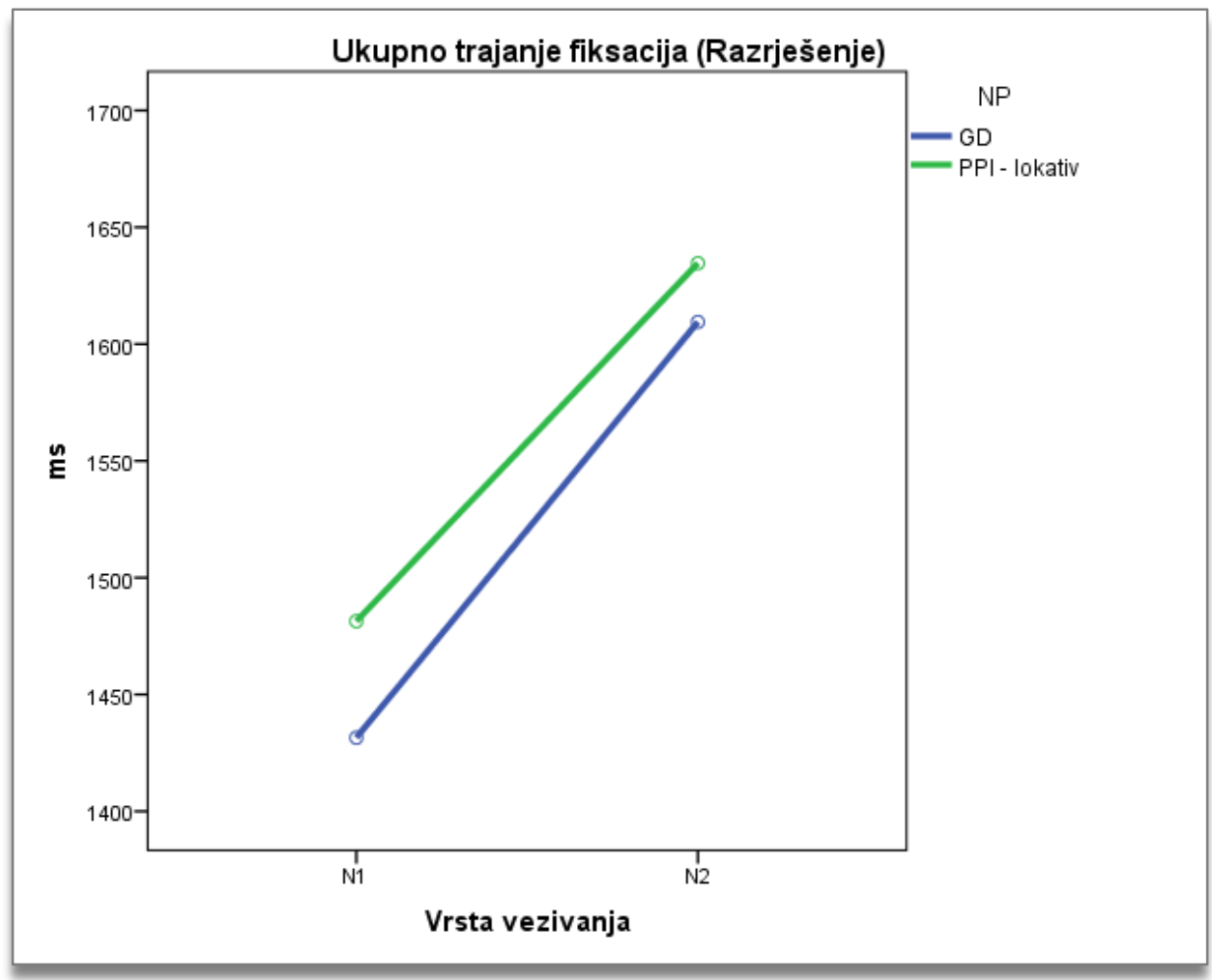

Slika 12. Grafički prikaz glavnih efekata na mjeri ukupno trajanje fiksacija u regiji Razrješenje dvosmislenosti (faktor vrsta vezivanja; N1/N2). 


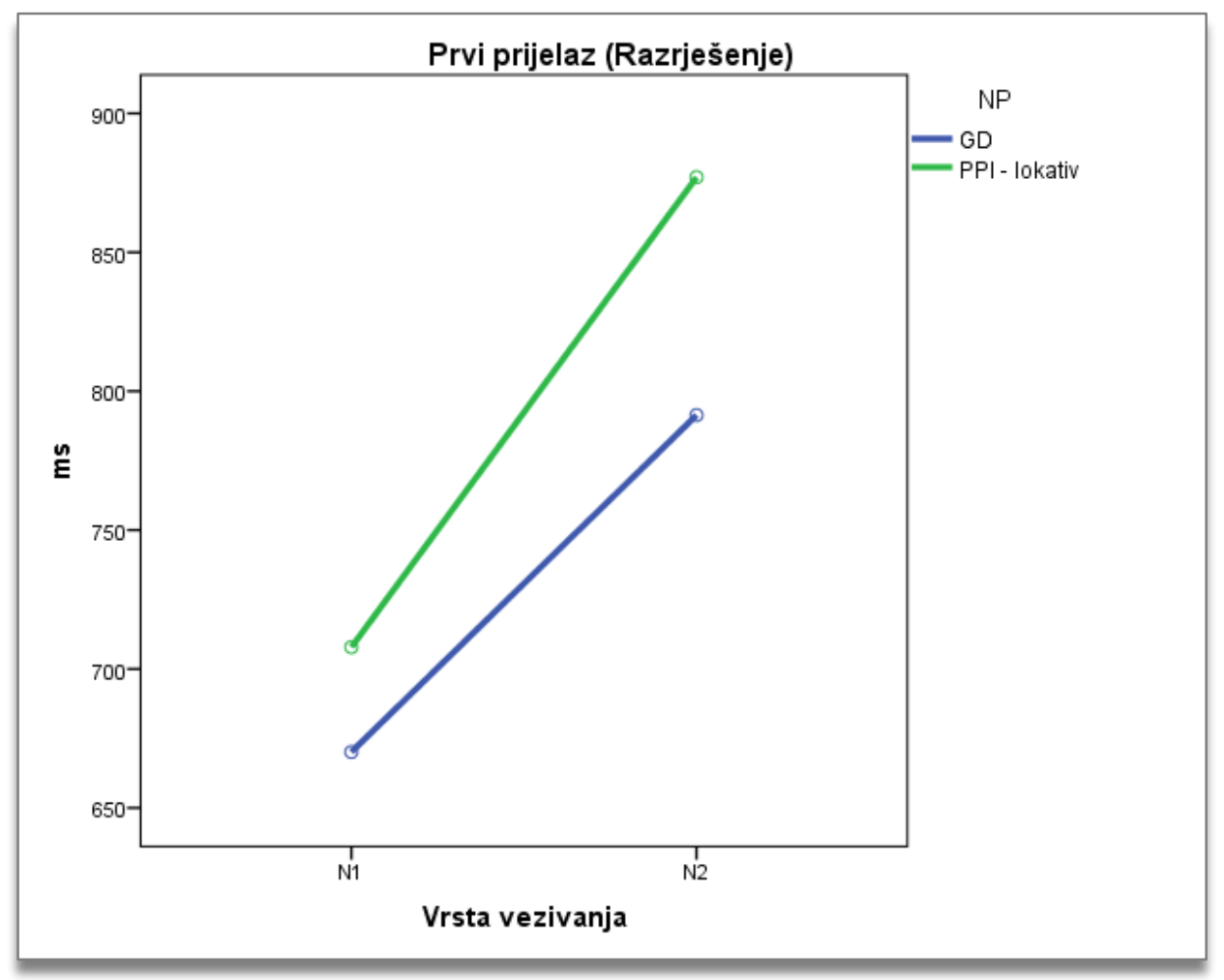

Slika 13. Grafički prikaz glavnih efekata na mjeri prvi prijelaz okom u regiji Razrješenje dvosmislenosti (faktor imenska skupina; GD/PPI).

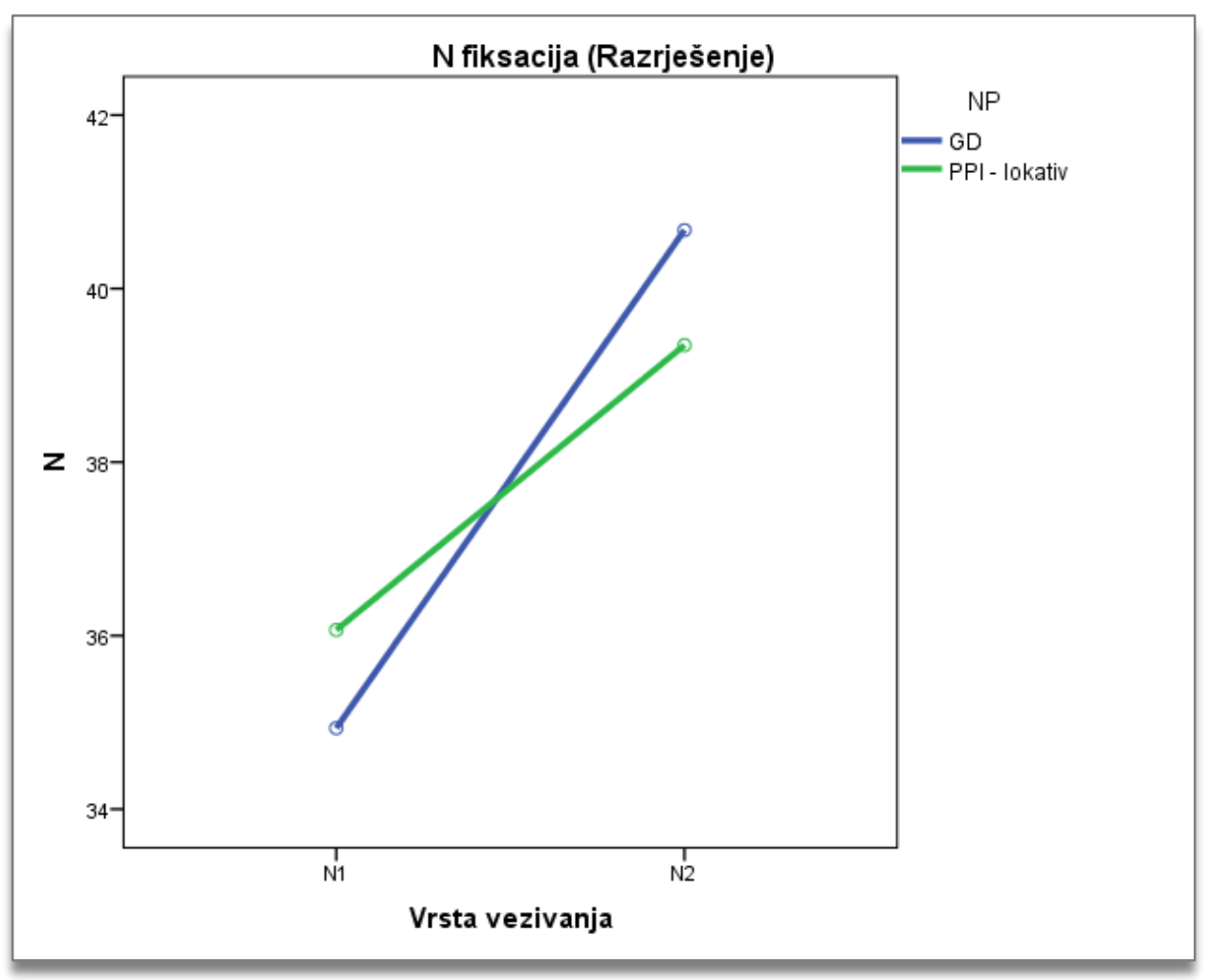

Slika 14. Grafički prikaz glavnih efekata na mjeri $N$ fiksacija u regiji Razrješenje dvosmislenosti (faktor vrsta vezivanja; N1/N2). 


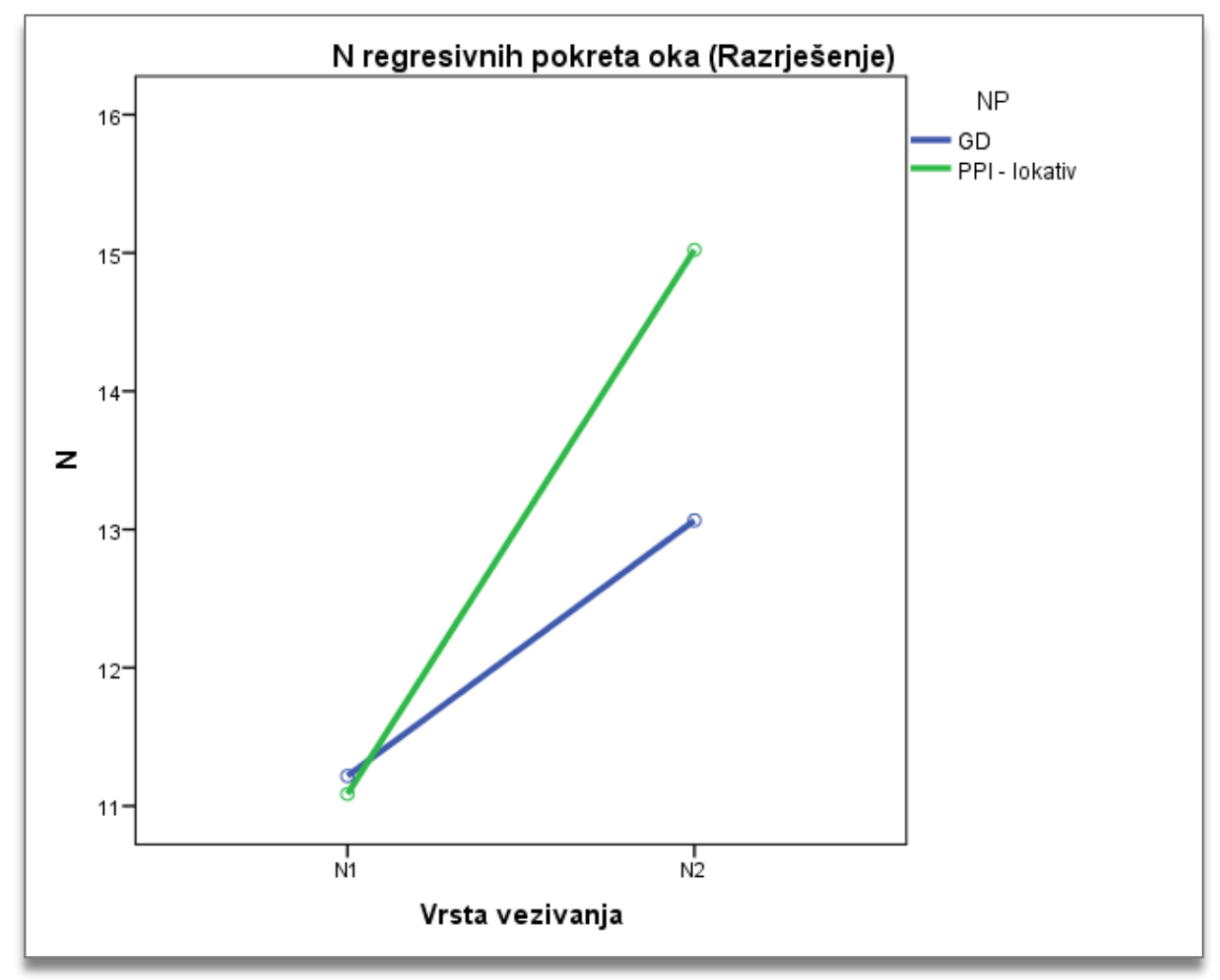

Slika 15. Grafički prikaz glavnih efekata na mjeri $N$ regresivnih pokreta oka u regiju Razrješenje dvosmislenosti (faktor vrsta vezivanja; N1/N2).

Značajni efekti za faktor imenska skupina; GD/PPI (Tablica 15) pokazuju da je sudionicima istraživanja značajno složenije bilo obraditi strukture s imenskim skupinama u prijedložnopadežnim izrazima negoli strukture s imenskim skupinama u genitivnim dopunama (vidi i prosječne vrijednosti tih mjera u Tablici 14).

Nadalje, takozvane vremenske mjere koje odražavaju trajanje čitanja i povezane su $\mathrm{s}$ obradbenim zahtjevima, u obje su vrste struktura (onima s GD i onima s PPI) značajno ili granično značajno produljene u uvjetima u kojima je ostvareno vezivanje na drugu imenicu unutar NP. Jednako tako, za obje te strukture zabilježen je značajno povećan broj regresivnih pokreta oka u ciljane regije, ali i općenito veći broj fiksacija u tekstu u uvjetu vezivanja na N2. Obradbeni je napor zabilježen na razini čitave rečenice (primjerice, ukupno vrijeme čitanja), kao i na razini pojedinačnih promatranih regija interesa. Značajno povećan broj regresivnih pokreta oka u regiju NP znakom je da su čitatelji nekoliko puta fiksirali ranije pročitani tekst u pokušaju dohvaćanja relevantne obavijesti koja je izostala ili tekst koji je uslijedio nakon prvog čitanja svojim sadržajem nije odgovarao onome što je čitatelj na nesvjesnoj razini predviđao. 
Za usporedbu dvaju uvjeta zbog utvrđivanja čitateljevih preferencija vezivanja posebno je važna druga regija interesa (razrješenje dvosmislenosti). Naime, upravo na tom mjestu u rečenici čitatelju postaje jasno o čemu se doista radi (primjerice, restoran *škole što je lijepo uređen (N1) naspram *dvorana hotela što je lijepo uređen (N2)). Kako je opisano u poglavlju 10.1. Razvoj ispitnih podražaja, zbog valjanih su analiza u svim rečenicama ti dijelovi potpuno ujednačeni po čestotnosti, duljini i sl. Usprkos tomu, u uvjetu vezivanja na N2 većina je mjera u ovoj regiji ili veća s obzirom na broj pojavljivanja (broj fiksacija i regresivnih pokreta oka) ili duljega trajanja (ukupno trajanje fiksacija i prvi prijelaz okom u regiji interesa), što je znakom značajno povećanih obradbenih zahtjeva u usporedbi s uvjetom u kojem je u toj ključnoj regiji ostvareno vezivanje na N1, a stoga i potvrdom jakih preferencija govornika (Tablica 16; Slike 10-15).

Još jedna vrlo vrijedna spoznaja odnosi se na činjenicu da je efekt dobiven i na tzv. kasnijim mjerama poput ukupnog trajanja fiksacija i na tzv. ranim mjerama, poput prvog prijelaza okom u ključnoj regiji u rečenici. Iako su obje mjere znakom većeg kognitivnog napora i teškoća u obradi (Liversedge i sur., 1998; Holmqvist i sur., 2011), prva obuhvaća sve fiksacije neovisno o tome kada je do njih došlo (tijekom prvog, drugog ili trećeg čitanja teksta u promatranoj regiji), dok potonja obuhvaća samo one fiksacije u regiji do kojih je došlo prije nego ju je oko napustilo u kojem god smjeru. Ova mjera stoga predstavlja vrlo važnu etapu u procesu integracije jezičnih obavijesti - znakom je da do prekida, teškoća ili pak neometane integracije obavijesti u obradi dolazi već vrlo rano, što su potvrdila i istraživanja Zagar i sur. (1997), Traxler i sur. (1998), Staub (2007), Kaya (2012) itd. (općenito o mjerama vidi u Holmqvist i sur., 2011).

Interakcije između faktora imenska skupina i vrsta vezivanja pokazale su se značajnima $(p<0,05)$ isključivo na mjeri broj regresivnih pokreta oka u regiju $\mathrm{NP}(\mathrm{F}(1,45)=13,125$; $\left.p=0,001 ; \eta^{2} p=0,226 ; P=0,943\right)$. Na mjerama broj fiksacija u regiji NP i broj regresivnih pokreta $o k a$ u regiju razrješenja dvosmislenosti dobivene vrijednosti približavaju se značajnosti, ali ju ne dostižu $(p=0,064$ i $p=0,065)$.

Vrijednosti interakcija između faktora koje su se pokazale značajnima zbog preglednosti su prikazane tablično (Tablica 17). 
Tablica 17. Interakcija između dvaju faktora (imenska skupina i vrsta vezivanja).

\begin{tabular}{ccccccc} 
Varijabla & Regija & $\boldsymbol{d f}$ & $\boldsymbol{F}$ & $\boldsymbol{p}$ & $\boldsymbol{\eta}^{2} \boldsymbol{p}$ & $\boldsymbol{P}$ \\
\hline $\begin{array}{c}N \text { regresivnih } \\
\text { pokreta oka }\end{array}$ & $\mathrm{NP}$ & 2,45 & 13,125 & 0,001 & 0,226 & 0,943 \\
\hline
\end{tabular}

Najznačajniji zaključak jest taj da kvantitativne bihevioralne mjere u pravilu ne pokazuju suprotne rezultate u uvjetima GD i PPI. U obje su te vrste imenskih skupina pronađene podjednake razlike u uvjetima vezivanja na N1 i N2 (povećan broj regresija i fiksacija, produljeno vrijeme čitanja i dulje trajanje fiksacija u potonjem uvjetu).

Kada bi vrsta imenske skupine doista utjecala na promjene preferencija, sve bi dobivene mjere pokazivale potpuno suprotne tendencije u uvjetu PPI (povećan broj regresija i fiksacija, produljeno vrijeme čitanja i dulje trajanje fiksacija u uvjetu u kojem je ostvareno vezivanje na N1). Drugim riječima, tada bi interakcije na svim mjerama, ili barem na većini njih, bile statistički značajne.

Čak niti ova jedina zabilježena interakcija između dvaju faktora (na varijabli $N$ regresivnih pokreta oka; Tablica 17) nije interakcija u suprotnim smjerovima, već je do nje došlo iz razloga što su vrijednosti razlika između razina na jednom od promatranih faktora značajno izraženije u odnosu na razlike između razina na drugome, što je vidljivo i iz grafičkoga prikaza na Slici 11. 
11.2.2. Utjecaj obilježja živosti na preferencije vezivanja (drugi eksperiment)

U ovom su eksperimentu za svaku mjeru u dvjema regijama interesa uspoređena dva faktora:

a) živost (s dvije razine; vezivanje na imenicu s obilježjem živo i s obilježjem neživo) te

b) vrsta vezivanja (s dvije razine; vezivanje na $\mathrm{N} 1$ i vezivanje na $\mathrm{N} 2$ ).

Zavisne su varijable bile jednake kao i u prethodnoj analizi, a nezavisne su varijable bili promatrani faktori.

Prosječan je postotak točnih odgovora na pitanja nakon ispitnih podražaja (u uvjetu N1 i N2) u ovom eksperimentu također bio vrlo visok. Svi su sudionici $(N=48)$ odgovarali u potpunosti točno (100\%) ili su samo sporadično griješili $(92,3 \%)$, zbog čega su se analizirali rezultati svih 48 sudionika.

U Tablici 18 prikazane su srednje vrijednosti svih analiziranih mjera u dvjema regijama interesa u oba uvjeta. Mjere trajanja izražene su u milisekundama (ms), dok su mjere promatranih događaja izražene kao sirove vrijednosti $(N)$. 
Tablica 18. Prosječne vrijednosti svih analiziranih mjera u svim uvjetima (drugi eksperiment u stvarnom vremenu).

\begin{tabular}{|c|c|c|c|c|}
\hline & \multicolumn{2}{|c|}{ Vezivanje na živo } & \multicolumn{2}{|c|}{ Vezivanje na neživo } \\
\hline $\begin{array}{l}\text { Mjere } \\
\text { ili } \\
\text { zavisne varijable }\end{array}$ & $\begin{array}{c}\text { Regija } \\
N P\end{array}$ & $\begin{array}{c}\text { Regija } \\
\text { Razrješenje } \\
\text { dvosmislenosti }\end{array}$ & $\begin{array}{c}\text { Regija } \\
N P\end{array}$ & $\begin{array}{c}\text { Regija } \\
\text { Razrješenje } \\
\text { dvosmislenosti }\end{array}$ \\
\hline \multicolumn{5}{|c|}{ Ukupno vrijeme čitanja $(\mathrm{ms})$} \\
\hline Uvjet Dvosmislena & \multicolumn{2}{|c|}{6747,22} & \multicolumn{2}{|c|}{6539,69} \\
\hline Uvjet N1 & \multicolumn{2}{|c|}{5801,45} & \multicolumn{2}{|c|}{6244,56} \\
\hline Uvjet N2 & \multicolumn{2}{|c|}{6340,25} & \multicolumn{2}{|c|}{6346,40} \\
\hline \multicolumn{5}{|c|}{ Ukupno trajanje fiksacija (ms) } \\
\hline Uvjet N1 & 1868,64 & 1195,55 & 2162,82 & 1203,99 \\
\hline Uvjet N2 & 2115,01 & 1266,13 & 2067,74 & 1280,61 \\
\hline \multicolumn{5}{|l|}{ Prvi prijelaz (ms) } \\
\hline Uvjet N1 & 1137,65 & 628,09 & 1201,31 & 662,69 \\
\hline Uvjet N2 & 1129,08 & 641,92 & 1054,9 & 696,89 \\
\hline \multicolumn{5}{|l|}{ Brojfiksacija $(N)$} \\
\hline Uvjet N1 & 47,1 & 31,35 & 53,04 & 30,4 \\
\hline Uvjet N2 & 53,6 & 32,92 & 53,38 & 32,38 \\
\hline \multicolumn{5}{|c|}{ Broj regresivnih pokreta oka (N) } \\
\hline Uvjet N1 & 8,27 & 8,27 & 8,81 & 8,17 \\
\hline Uvjet N2 & 9,79 & 9,4 & 9,52 & 9,58 \\
\hline
\end{tabular}

Iz vrijednosti u Tablici 18 ponovno je vidljivo da su osobe prosječno više vremena provele čitajući rečenice (i njihove ključne dijelove) u kojima je ostvareno vezivanje na drugu imenicu unutar NP. To je posebice izraženo u regiji razrješenja dvosmislenosti, odnosno u regiji u kojoj se čitatelju sugerira točna interpretacija, tj. vezivanje na odgovarajući antecedent. Drugim riječima, rezultati pokazuju da je upravo uvjet N2 zahtjevniji za obradu. Također, niže se vrijednosti (kraće vrijeme čitanja i trajanje fiksacija) uočavaju u uvjetima u kojima se odnosna surečenica odnosi na imenicu u NP s obilježjem živo, nego u uvjetima u kojima se odnosi na imenicu s obilježjem neživo, što pokazuje da kategorija živosti utječe na obradu. 
Radi provjere značajnosti opaženih tendencija, za svaku je regiju i svaku zavisnu varijablu učinjena 2x2 rmANOVA. U nastavku će se prikazati glavni efekti i interakcije, ponovno na razini značajnosti od $5 \%$.

Značajni su efekti dobiveni na oba faktora, živost (živo/neživo) i vrsta vezivanja (N1/N2), na obje promatrane regije interesa u rečenici. Glavni efekti $(p<0,05)$ za faktor živost dobiveni su na mjerama ukupno vrijeme čitanja $\left(\mathrm{F}(1,47)=4,547 ; p=0,038 ; \eta^{2} p=0,088 ; P=0,551\right)$, ukupno trajanje fiksacija u regiji NP $\left(\mathrm{F}(1,47)=6,718 ; p=0,013 ; \eta^{2} p=0,125 ; P=0,719\right)$, kao i broj fiksacija u istoj regiji $\left(\mathrm{F}(1,47)=8,018 ; p=0,007 ; \eta^{2} p=0,146 ; P=0,792\right)$ te prvi prijelaz okom u regiji razrješenja dvosmislenosti $\left(\mathrm{F}(1,47)=6,117 ; p=0,017 ; \eta^{2} p=0,115 ; P=0,678\right)$.

Glavni efekti za faktor vrsta vezivanja dobiveni su na mjerama ukupno vrijeme čitanja $\left(\mathrm{F}(1,47)=7,829 ; p=0,007 ; \eta^{2} p=0,143 ; P=0,782\right)$, prvi prijelaz okom u regiji $\mathrm{NP}(\mathrm{F}(1,47)=6,692$; $\left.p=0,013 ; \eta^{2} p=0,125 ; P=0,717\right)$, broj fiksacija u regiji $\mathrm{NP}\left(\mathrm{F}(1,47)=11,603 ; p=0,001 ; \eta^{2} p=0,198\right.$; $P=0,916)$, broj regresivnih pokreta oka u regiju $\mathrm{NP} F(1,47)=11,364 ; p=0,002 ; \eta^{2} p=0,195$; $P=0,910)$ te broj regresivnih pokreta oka u regiju razrješenja dvosmislenosti $(\mathrm{F}(1,47)=9,109$; $\left.p=0,004 ; \eta^{2} p=0,162 ; P=0,840\right)$.

Glavni su efekti na promatranim mjerama (zavisnim varijablama istraživanja) za obje regije i oba promatrana faktora zbog preglednosti prikazani tablično (Tablice 19 i 20) i grafički (Slike 16-21).

Tablica 19. Prikaz glavnih efekata na promatranim mjerama (zavisnim varijablama) za faktor živost; živo/neživo (drugi eksperiment u stvarnom vremenu).

\begin{tabular}{ccccccc} 
Varijabla & Regija & $\boldsymbol{d} \boldsymbol{f}$ & $\boldsymbol{F}$ & $\boldsymbol{p}$ & $\boldsymbol{\eta}^{2} \boldsymbol{p}$ & $\boldsymbol{P}$ \\
\hline \hline $\begin{array}{c}\text { Ukupno } \\
\text { vrijeme } \\
\text { čitanja }\end{array}$ & Cijela rečenica & 1,47 & 4,547 & 0,038 & 0,088 & 0,551 \\
\hline $\begin{array}{c}\text { Ukupno } \\
\text { trajanje } \\
\text { fiksacija }\end{array}$ & NP & 1,47 & 6,718 & 0,013 & 0,125 & 0,719 \\
\hline$N$ fiksacija & & 1,47 & 8,018 & 0,007 & 0,146 & 0,792 \\
\hline & & & & & & \\
\hline Prvi prijelaz & $\begin{array}{c}\text { Razrješenje } \\
\text { dvosmislenosti }\end{array}$ & 1,47 & 6,117 & 0,017 & 0,115 & 0,678 \\
\hline
\end{tabular}


Tablica 20. Prikaz glavnih efekata na promatranim mjerama (zavisnim varijablama) za faktor vrsta vezivanja; N1/N2 (drugi eksperiment u stvarnom vremenu).

\begin{tabular}{|c|c|c|c|c|c|c|}
\hline Varijabla & Regija & $d f$ & $\boldsymbol{F}$ & $p$ & $\eta_{p}^{2}$ & $P$ \\
\hline $\begin{array}{l}\text { Ukupno } \\
\text { vrijeme } \\
\text { čitanja }\end{array}$ & Cijela rečenica & 1,47 & 7,829 & 0,007 & 0,143 & 0,782 \\
\hline Prvi prijelaz & \multirow{3}{*}{ NP } & 1,47 & 6,692 & 0,013 & 0,125 & 0,717 \\
\hline$N$ fiksacija & & 1,47 & 11,603 & 0,001 & 0,198 & 0,916 \\
\hline $\begin{array}{c}N \text { regresivnih } \\
\text { pokreta oka }\end{array}$ & & 1,47 & 11,364 & 0,002 & 0,195 & 0,910 \\
\hline $\begin{array}{c}N \text { regresivnih } \\
\text { pokreta oka }\end{array}$ & $\begin{array}{c}\text { Razrješenje } \\
\text { dvosmislenosti }\end{array}$ & 1,47 & 9,109 & 0,004 & 0,162 & 0,840 \\
\hline
\end{tabular}

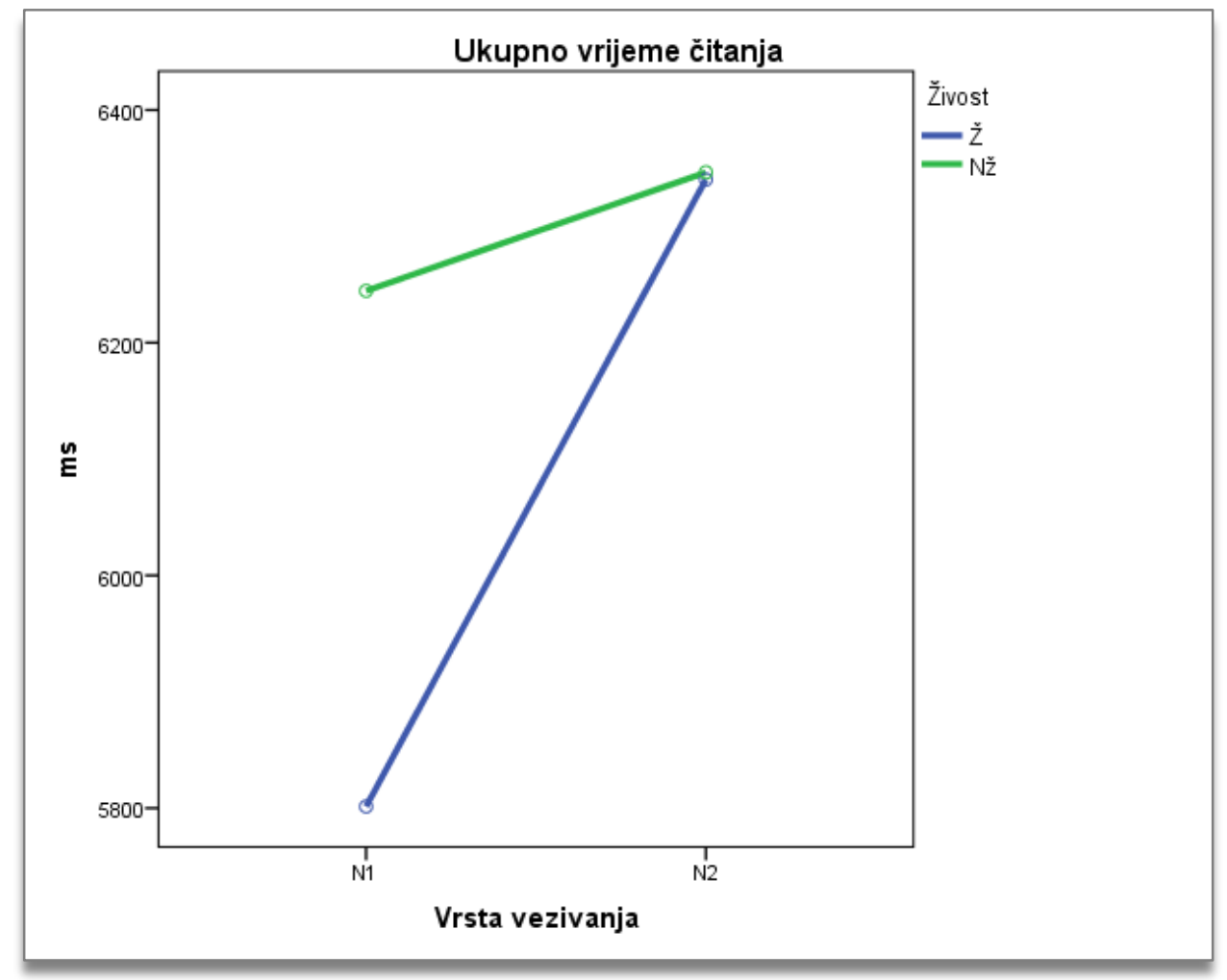

Slika 16. Grafički prikaz glavnih efekata na mjeri ukupno vrijeme čitanja (faktor živost; živo/neživo i vrsta vezivanja; N1/N2). 


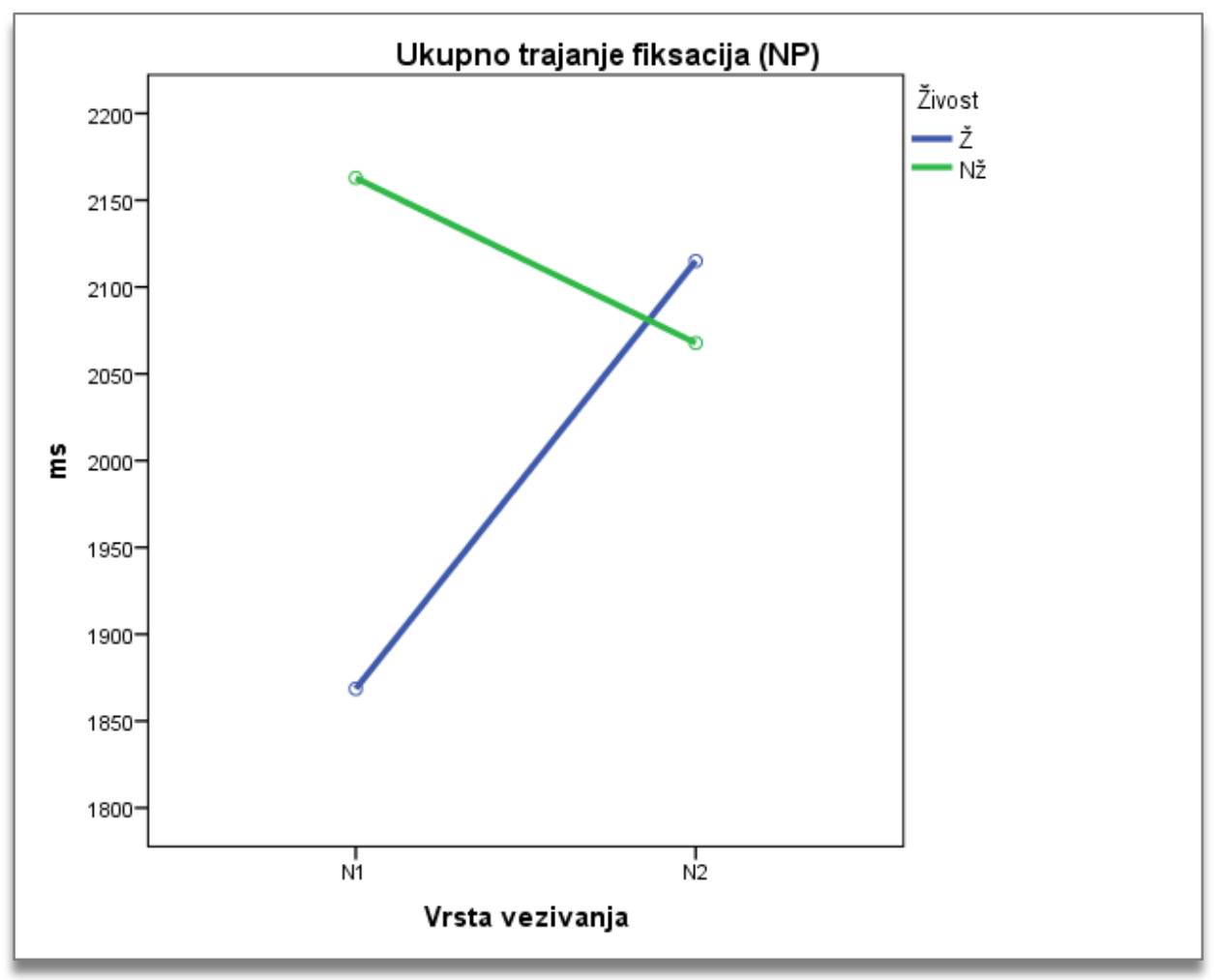

Slika 17. Grafički prikaz glavnih efekata na mjeri ukupno trajanje fiksacija u regiji NP (faktor živost; živo/neživo).

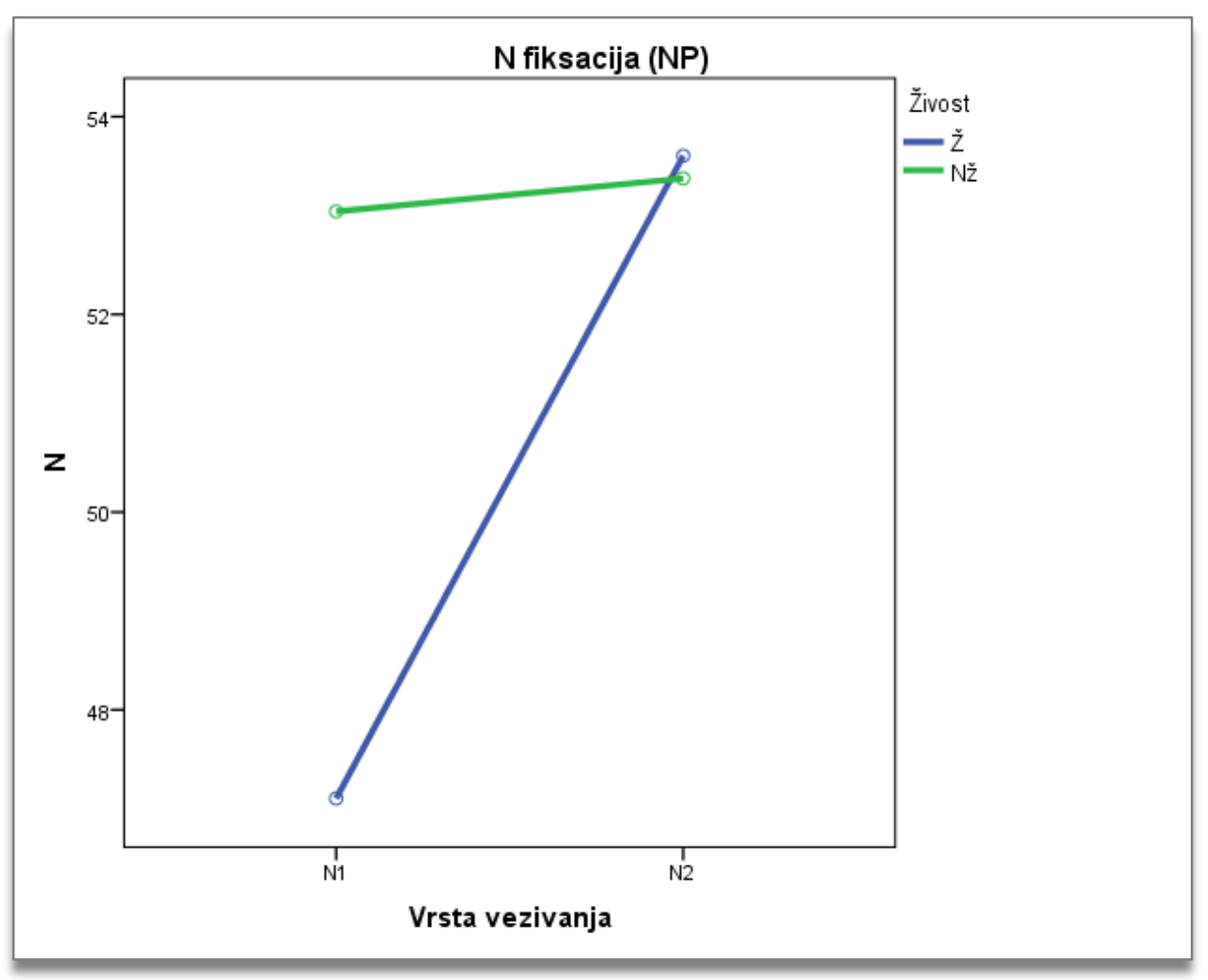

Slika 18. Grafički prikaz glavnih efekata na mjeri $N$ fiksacija u regiji NP (faktor živost; živo/neživo i vrsta vezivanja; N1/N2). 


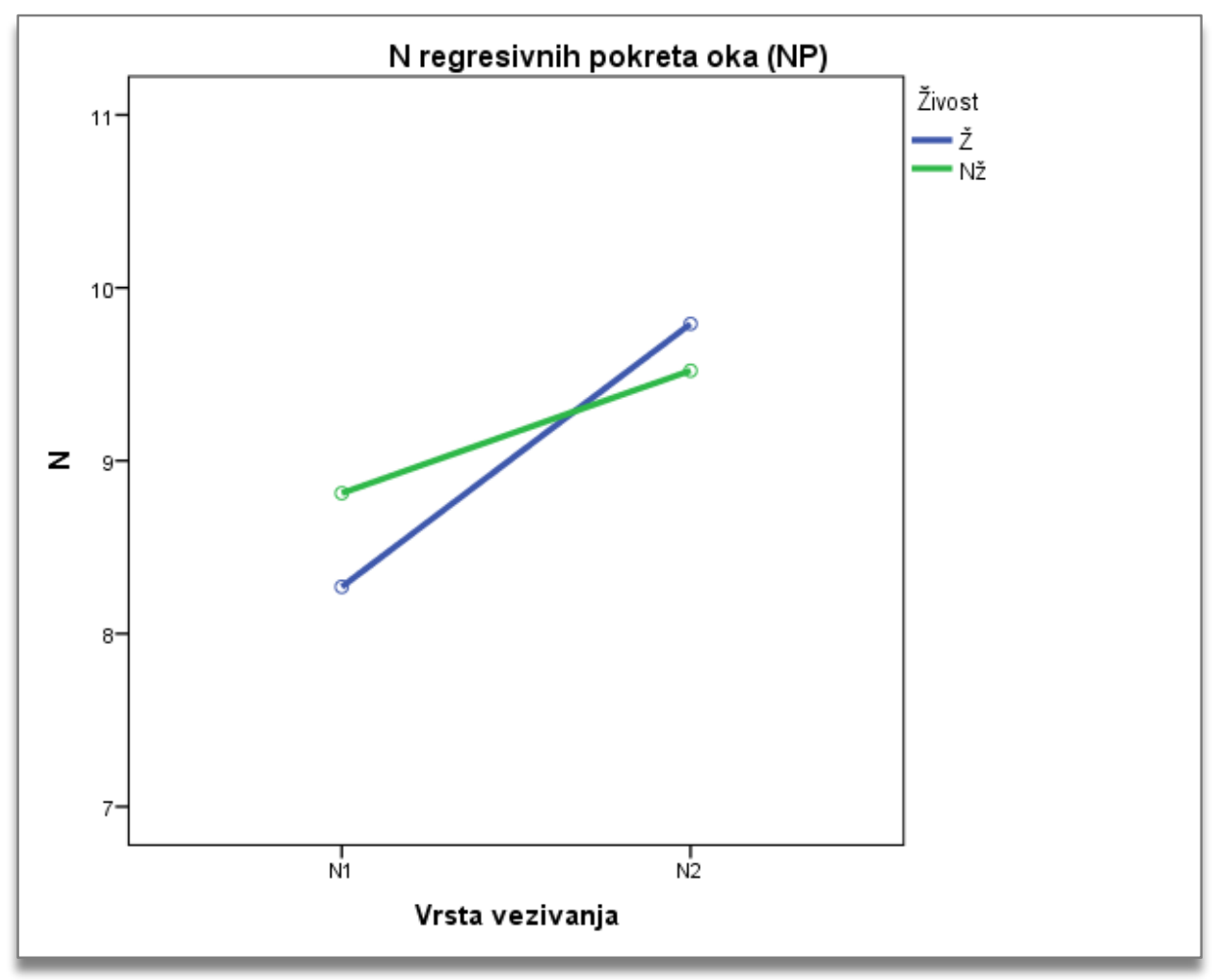

Slika 19. Grafički prikaz glavnih efekata na mjeri $N$ regresivnih pokreta oka u regiju NP (faktor vrsta vezivanja; N1/N2).

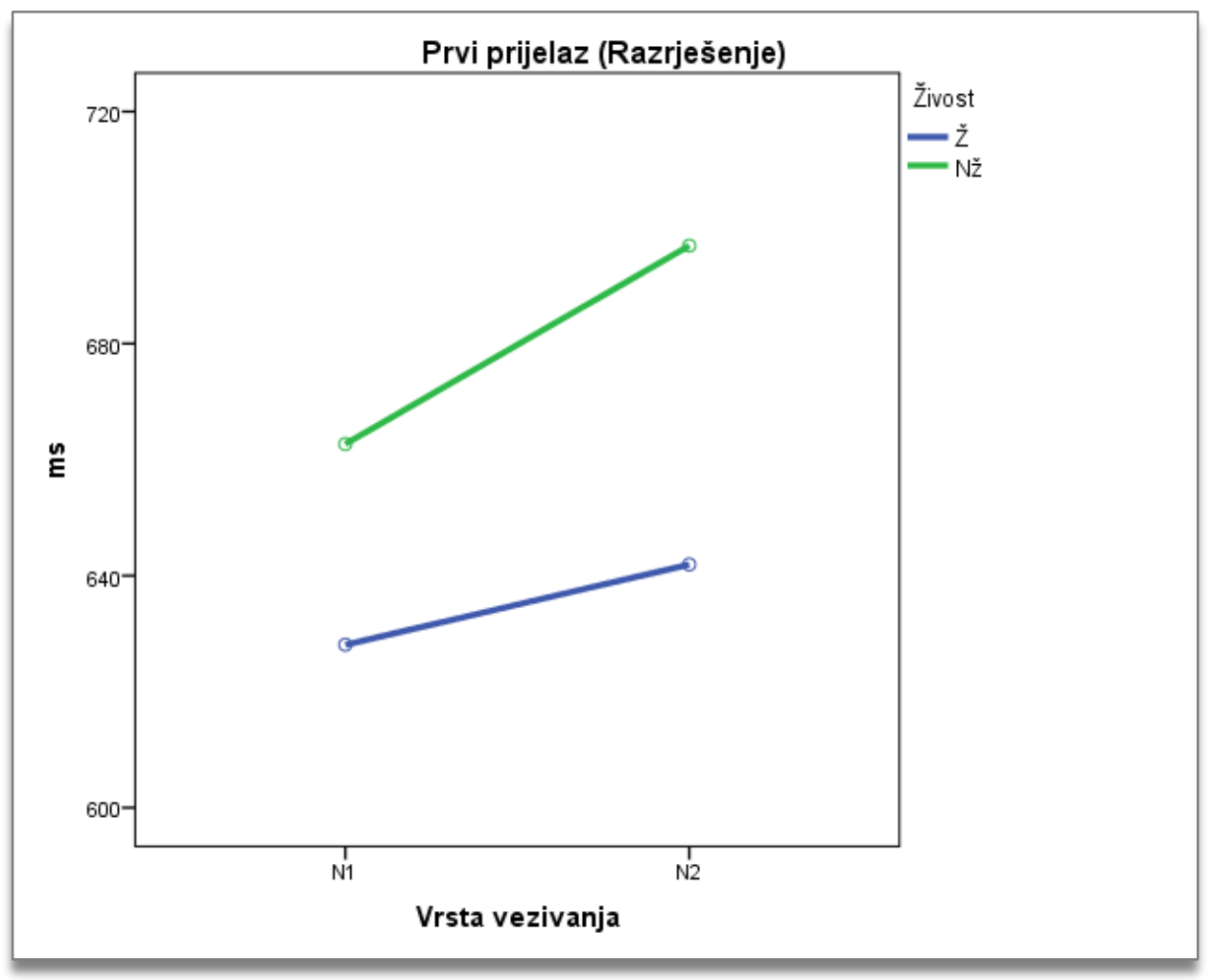

Slika 20. Grafički prikaz glavnih efekata na mjeri prvi prijelaz okom u regiji Razrješenje dvosmislenosti (faktor živost; živo/neživo). 


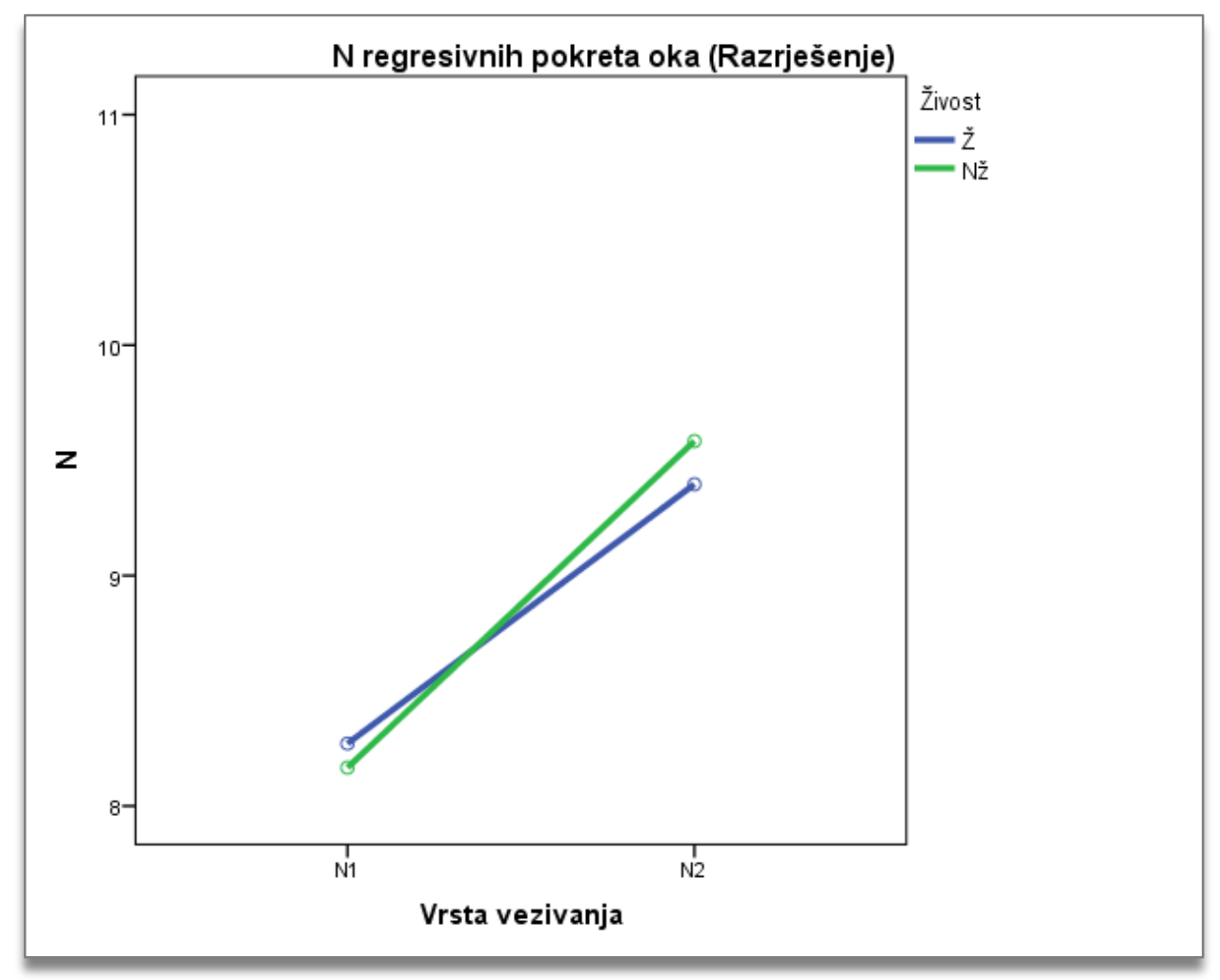

Slika 21. Grafički prikaz glavnih efekata na mjeri $N$ regresivnih pokreta oka u regiju Razrješenje dvosmislenosti (faktor vrsta vezivanja; N1/N2).

Dobiveni značajni efekti za faktor živost; živo/neživo (Tablica 19) jasan su pokazatelj da kategorija živosti utječe na obradu. Iz prosječnih se vrijednosti mjera iskazanih u Tablici 18 može iščitati da su rečenice u kojima su imenice u NP imale različita obilježja s obzirom na tu kategoriju (primjerice, kapetan $^{+}$broda $^{-}$), a u kojima je ostvareno vezivanje na imenicu s obilježjem živo, govornicima bile manje zahtjevne za obradu. Naime, značajno kraće vrijeme čitanja te manji broj fiksacija i regresivnih pokreta oka ostvareni su upravo u uvjetima vezivanja na imenicu s obilježjem živo, negoli na onu s obilježjem neživo. Osim toga, u strukturama u kojima se odnosna surečenica vezuje na imenicu s obilježjem neživo mjere su, neovisno o položaju imenice, približno ujednačene, dok su u uvjetima vezivanja na imenicu s obilježjem živo razlike kudikamo izraženije i ovise o položaju te imenice unutar NP (kraće vrijeme čitanja i značajno manji broj fiksacija u uvjetu vezivanja na N1).

Jednako kao i u prethodnom eksperimentu, položaj imenice u imenskoj skupini imao je vrlo snažan utjecaj na obradu (Tablica 20). Niže su vrijednosti ponovno zabilježene u uvjetima u kojima je ostvareno vezivanje na N1, što je još jedan snažan pokazatelj preferencija govornika hrvatskoga, odnosno otežane obrade u uvjetu vezivanja na N2 (Tablica 18). 
Interakcije između faktora pokazale su se značajnima na mjerama ukupno trajanje fiksacija $\mathrm{u}$ regiji NP $\left(\mathrm{F}(1,47)=8,833 ; p=0,005 ; \eta^{2} p=0,158 ; P=0,829\right)$, prvi prijelaz okom u regiji NP $\left.\mathrm{F}(1,47)=5,282 ; p=0,026 ; \eta^{2} p=0,101 ; P=0,615\right)$ te broj fiksacija u regiji $\mathrm{NP}(\mathrm{F}(1,47)=5,763$; $\left.p=0,020 ; \eta^{2} p=0,109 ; P=0,652\right)$.

Vrijednosti interakcija između faktora koje su se pokazale značajnima zbog preglednosti su prikazane tablično (Tablica 21).

Tablica 21. Interakcija između dvaju faktora (živost i vrsta vezivanja).

\begin{tabular}{ccccccc} 
Varijabla & Regija & $\boldsymbol{d} \boldsymbol{f}$ & $\boldsymbol{F}$ & $\boldsymbol{p}$ & $\boldsymbol{\eta}^{2} \boldsymbol{p}$ & $\boldsymbol{P}$ \\
\hline \hline $\begin{array}{c}\text { Ukupno } \\
\text { trajanje } \\
\text { fiksacija }\end{array}$ & NP & 2,47 & 8,833 & 0,005 & 0,158 & 0,829 \\
\hline Prvi prijelaz & & & & & & \\
\hline$N$ fiksacija & & 2,47 & 5,282 & 0,026 & 0,101 & 0,615 \\
\cline { 2 - 7 } & & 2,47 & 5,763 & 0,020 & 0,109 & 0,652 \\
\hline
\end{tabular}

Interakcija na mjeri broja fiksacija u prvoj promatranoj regiji interesa (NP) posljedica je činjenice da su razlike s obzirom na vrstu vezivanja vrlo jake u uvjetu živo (47,1 za N1 naspram 53,6 za N2), dok ih u uvjetu neživo gotovo ni nema (53,04 za N1 naspram 53,38 za N2; vidi Tablicu 18 i Sliku 18). Ukupno je trajanje fiksacija u toj regiji jedina mjera u kojoj se primjećuje efekt suprotan od svih ostalih, a to je kraće trajanje za vezivanje na N2 u uvjetu neživo.

Budući da je vrijednost mjere prvog prijelaza relevantna isključivo u regiji u kojoj ključna obavijest čitatelju postaje dostupna (u ovom slučaju je to regija razrješenja), dobivenu interakciju u početnoj regiji u rečenici nije moguće povezati s teorijskim postavkama, tj. interpretirati na valjan način.

U svim je tablicama (Tablice 15-17 i 19-21) navedena i snaga dobivenih efekata. U posljednjem je stupcu vrijednost opažene snage $(P)$ koja se izračunava na temelju veličine uzorka i ostvarene značajnosti. Vrijednosti iznad 0,5 smatraju se umjerenim do jakim, a vrijednosti iznad 0,8 vrlo jakim (snažnim) efektima. U ovom su istraživanju u najvećem broju slučajeva zabilježeni upravo vrlo snažni efekti (>0,5, pa čak i >0,99; vidi Tablice 15-17 i 19-21). Vrijednosti u pretposljednjem stupcu $\left(\eta^{2}\right)$ pokazuju koji je postotak varijance u rezultatima na ispitanoj mjeri objašnjen upravo dobivenim (značajnim) efektom. Vrijednosti na mjerama koje su se promatrale u ovom ispitivanju variraju od 0,08 do 0,46 , što je u odnosu na druga istraživanja 
relativno visoka vrijednost, posebice ako se u obzir uzme količina promatranih mjera. ${ }^{46} \mathrm{Načelno}$ se smatra da već i vrijednosti $\eta_{p}^{2}>0,14$ govore o velikom utjecaju toga efekta ili mjere na ispitanu pojavnost. Najveće su vrijednosti snage efekta dobivene za faktor vrsta vezivanja; N1/N2, i to na mjerama trajanja fiksacija i broja regresivnih pokreta oka (vidi Tablice 15-17 i 19-21).

Kako bi navedene brojčane podatke bilo lakše predočiti i povezati sa samim eksperimentom i obilježjima čitanja pojedinačnih sudionika, u nastavku su prikazane slike koje su izlazni proizvod uređaja za praćenje pokreta očiju.

Ti slikovni prikazi (Slike 22 i 23) ocrtavaju prirodu fiksacija, njihov broj i trajanje s obzirom na uvjete. Krug na slikovnome prikazu predstavlja fiksaciju, a njegova veličina ocrtava trajanje fiksacije. Što je krugova više, to je osoba češće fiksirala određeno područje. Nadalje, što je krug veći, to je fiksacija dulja, odnosno uvjet je čitatelju obradbeno zahtjevniji. Broj unutar kruga predstavlja broj fiksacije, kako bi bilo jednostavnije pratiti njihov redoslijed i odrediti smjer čitanja te uvidjeti je li došlo do regresije i koliko se često to dogodilo.

\footnotetext{
${ }^{46}$ Promatranjem tendencija kretanja tih postotaka u sličnim i međusobno usporedivim istraživanjima postupno se mogu izdvojiti konkretni efekti i mjere koji najbolje objašnjavaju ispitane pojavnosti.
} 
Slika 22 prikazuje sudionikovo čitanje ispitnih podražaja u prvom eksperimentu (odnosna rečenica s imenskom skupinom u prijedložno-padežnom izrazu), pri čemu je u gornjem retku prikazana rečenica u kojoj je ostvareno vezivanje na N1, dok je u rečenici u donjem retku prikazana rečenica u kojoj je ostvareno vezivanje na N2.

\section{N1 \\ ${ }^{44}$ Hotel na obsi štgaje prepun stranqua postaje atrakcija širom Europe.}

N2
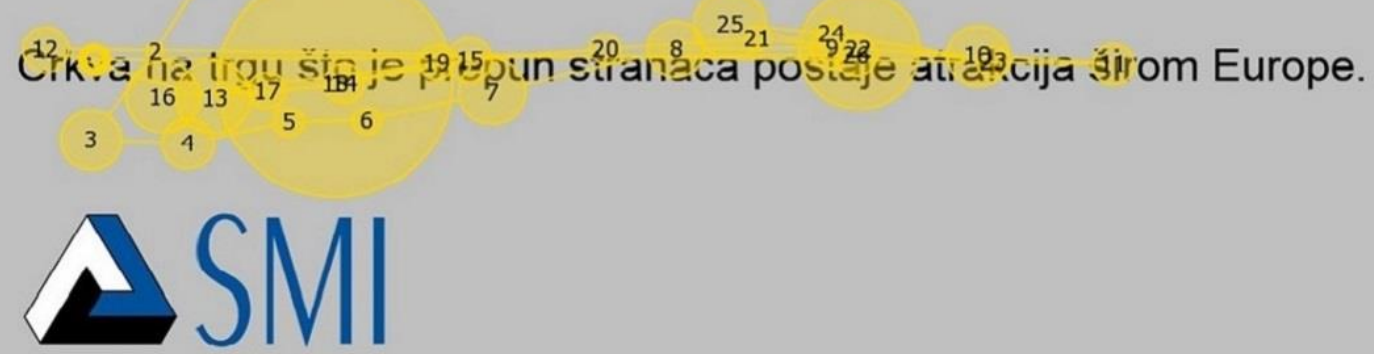

SensoMotoric Instruments

Slika 22. Prikaz pokreta oka (fiksacije, sakade i regresije) u uvjetima vezivanja na N1 i N2 (prvi eksperiment).

Usporedbom dvaju uvjeta vezivanja na Slici 22 primjetan je manji broj fiksacija i njihovo kraće trajanje, kao i manji broj regresivnih pokreta oka u rečenici u prvome retku, tj. u uvjetu u kojem je ostvareno vezivanje na prvu imenicu unutar imenske skupine. 
Slika 23 prikazuje sudionikovo čitanje ispitnih podražaja u drugom eksperimentu (odnosna rečenica u kojoj je eksperimentalno ostvareno vezivanje na imenicu s obilježjem živo), pri čemu je u gornjem retku imenica s obilježjem živo na inicijalnome mjestu (vezivanje na N1), dok je u donjem retku ona na drugom mjestu unutar imenske skupine (vezivanje na N2).

\section{N1}

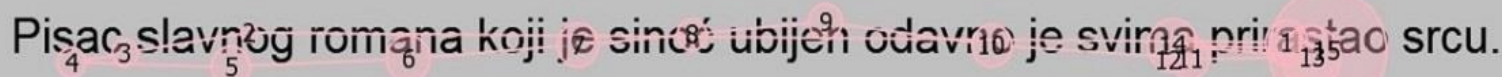

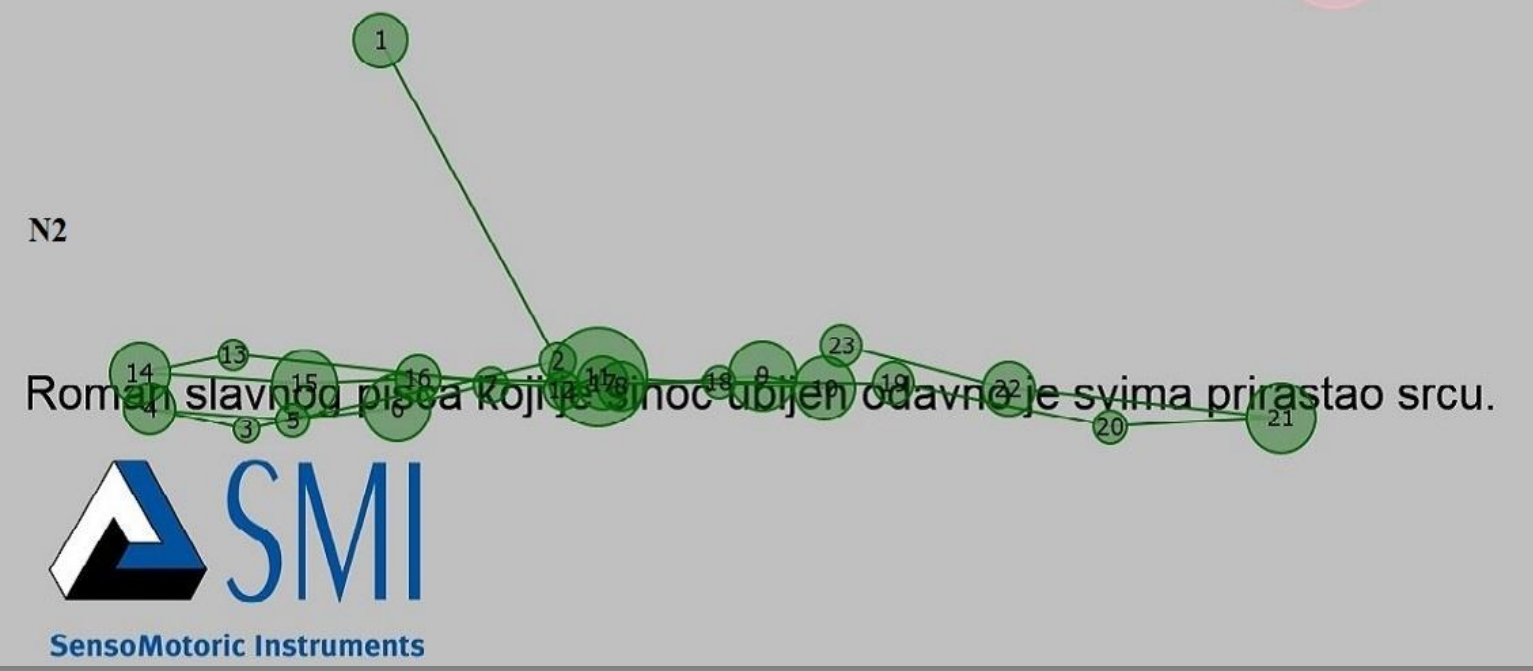

Slika 23. Prikaz pokreta oka (fiksacije, sakade i regresije) u uvjetima vezivanja na N1 i N2 (drugi eksperiment).

Usporedbom dvaju uvjeta na Slici 23 ponovno je primjetan manji broj fiksacija i njihovo kraće trajanje te manji broj povrataka na već pročitano u rečenici u prvome retku, odnosno u uvjetu u kojem se imenica s obilježjem živo (ujedno i imenica na koju odnosna surečenica svojim sadržajem upućuje) nalazi na prvome mjestu unutar imenske skupine.

Za slikovni su prikaz odabrani samo primjeri s imenskom skupinom u prijedložno-padežnom izrazu i primjeri u kojima je ostvareno vezivanje na živo jer su upravo u tim uvjetima ostvareni jači efekti nego u preostalim uvjetima (genitivna dopuna i vezivanje na neživo). Ipak, isti se trend na sličan način pojavljuje i u preostalim primjerima - što potvrđuju ranije opisani rezultati - samo je zbog nižih vrijednosti statističkoga efekta on izražen u nešto manjoj mjeri. 


\subsection{Kvalitativni podatci: osjećaj izvornoga govornika}

Kako bi rezultati istraživanja dodatno dobili na snazi, a dobivene spoznaje imale još jedno uporište, osim kvantitativnih rezultata triju opisanih eksperimenata, u različitim je fazama istraživanja nekoliko sudionika dalo i kratke (usmene ili pisane) osvrte, tj. izjave o razlozima odabira jednoga ili drugog antecedenta u upitniku.

Prikupljanje kvalitativnih podataka o iskustvima izvornih govornika vrijedno je iz sljedećih razloga: na taj se način s jedne strane izbjegava nehotična pristranost istraživača u interpretaciji i generalizaciji kvantitativnih rezultata istraživanja, a s druge se strane iz prve ruke dobiva jasan uvid u intuiciju, tj. osjećaj izvornoga govornika (Skopeteas, 2012). Iako to donekle usložnjava nacrt i produljuje trajanje eksperimenta, itekako doprinosi valjanosti rezultata i višeslojnosti rasprave (Poulsen, 2005).

Neki su sudionici po dovršetku ispunjavanja upitnika sa zadatcima prosudbe samoinicijativno komentirali svoj odabir, najčešće zbog bojazni da su nešto pogrešno shvatili ili iz razloga što nisu sigurni kako su to odradili jer nisu mogli lako odlučiti, budući da im se sve opcije čine jednako mogućima. Neki su pak po završetku istraživanja usmeno odgovorili na izravno postavljeno pitanje Čime ste se vodili u odabiru?, a nekolicina je elektroničkom poštom dostavila svoje općenito mišljenje o istraživanju. Iz usmenih odgovora i pisanih poruka pristiglih elektroničkom poštom odabrani su dijelovi koji se jasno tiču sudionikovih odabira, tj. onoga čime su se kao pojedinci vodili u određivanju antecedenta dvosmislenih struktura.

Nakon uvida u iskaze, izdvojena su četiri čimbenika kojima su se govornici prvenstveno vodili: strukturni, obavijesni, prozodijski te osjećaj izvornoga govornika. Zabilježeno je nekoliko iskaza, a u nastavku je tablični prikaz (Tablica 22) s najjasnijim primjerima. Nejasni su ili nepotpuni primjeri izostavljeni. U prvome su stupcu izdvojeni dijelovi iskaza sudionika, a u posljednjem prevladavajući čimbenik (ili više njih) kojim(a) se sudionik vodio. Posebno su istaknuti oni dijelovi iskaza koji se vrlo jasno mogu dovesti u vezu s jednim od četiriju navedenih čimbenika. Iako primjera nema mnogo, oni vrlo jasno pokazuju međuovisnost čimbenika kojima se govornici vode u interpretaciji, što dodatno potvrđuje složenost mehanizama obrade i međudjelovanje strukturnih, prozodijskih, značenjskih, pragmatičkih i/ili diskursnih čimbenika (vidi Wind Cowles, 2012; Reich, 2012; Van Valin, 2001; 2019).

Bez obzira što izvorni govornik toga nije svjestan, navedeni su čimbenici neprestano u međudjelovanju, posebice u slučaju povećanih obradbenih zahtjeva. 
Tablica 22. Iskazi nekih sudionika i čimbenici koji su utjecali na njihove preferencije prilikom ispunjavanja upitnika.

Izdvojeni dio iskaza

Utjecajni čimbenik

Kad čitam u sebi, nekako mi je kao da čitam naglas. Stanem gdje mislim da treba, pa mi se zato čini da sam dobro zaokružio. Ali ne znam, to nekako ne vrijedi uvijek.

Prozodijski

Kod nekih mi je bilo baš lagano. Ono s tvornicom ili s utrkom (*aludira na primjere tvornica čokolade koja je proslavila zemlju i *dionica utrke koja je jako naporna), al' teško mi je kad ne znam jel' sin, tata, tko već (*aludira na Strukturni primjer *sin poznatog trenera koji ima tešku bolest).

Joj, pomogli bi mi zarezi. Ovako me zbunilo. Imam osjećaj da bih drugačije zaokružila da je bio zarez. Ali ne mogu znati sto posto.

Prozodijski

Strukturni

A jel' ima uopće točno rješenje? Nekad imam osjećaj da tak' govore na Prozodijski televiziji. Niš' ne kužim. Umjesto da to kažu nekak' drugačije, ili da zastanu malo. Možda je to i poanta, da nitko niš' ne kuži.

Strukturni

Uglavnom mi je bio ovaj prvi. Ne znam, čini mi se kao da je baš to bitno za

Obavijesni rečenicu. Ali možda sam se previše vraćala i mozgala.

Strukturni

A ne znam, zašto bi sad baš spominjali cijelu šumu, ako je bitna samo staza

Obavijesni (*aludira na primjer staza u šumi koja je prepuna stakla). A opet, možda je bitno da je ta staza u igri, baš ta iz te i te šume. Nemam pojma više ni što sam stavila na kraju. Vjerojatno ono što mi je tad došlo.

Osjećaj izvornoga govornika

Evo, ja sam Vas skroz poslušao i zaokružio prvo što mi je palo napamet. Nekako mi je baš tako došlo, a sad jel' dobro ...

Malo mi fali kontekst, ali vjerojatno je baš u tom stvar, pa niste blesavi.

Osjećaj izvornoga govornika

Znam da ne smijete reći kaj se točno ispituje... Al' ja uopće ne znam čime sam se vodila. Totalno instinktivno sam odgovarala, bar na početku...

Osjećaj izvornoga govornika 


\subsection{Usporedba obrade dvosmislenih i nedvosmislenih rečenica}

Iako konstrualna hipoteza nema jasnih pretpostavki o serijalnosti i paralelnosti u obradi, nacrt istraživanja oblikovan je tako da omogući dodatno stjecanje uvida u to dolazi li prilikom sintaktičke obrade do kompeticije u obradi (što zagovaraju interaktivni modeli) ili govornici unaprijed grade isključivo jednu interpretaciju rečenice, a razine se ne sukobljavaju (što zagovara model neograničene utrke i, donekle, tradicionalni modularni modeli).

Upravo radi dodatne usporedbe obradbenih zahtjeva prilikom čitanja dvosmislenih naspram nedvosmislenih struktura, $t$-testom su na varijabli ukupno vrijeme čitanja međusobno uspoređene rečenice s jednakom mogućnošću vezivanja na obje imenice zbog dvosmislenosti, s rečenicama u kojima je ostvareno vezivanje na N1 i onima u kojima je ostvareno vezivanje na N2. Usporedba je provedena na rezultatima obaju eksperimenata u stvarnom vremenu.

Rezultati $t$-testa provedenoga na kvantitativnim rezultatima prvog eksperimenta pokazuju kako su sudionici $(N=46)$ statistički značajno više vremena provodili čitajući dvosmislene odnosne strukture s prijedložno-padežnim izrazima $(\mathrm{M}=6651,08 ; \mathrm{SD}=2596,98)$ nego iste odnosne strukture u kojima je ostvareno vezivanje na $\mathrm{N} 1 \quad(\mathrm{M}=5933,47 ; \mathrm{SD}=1885,92) \quad(t=3,15$; $p=0,003^{47}$ ). Srednje vrijednosti za ukupno vrijeme čitanja u svim uvjetima (Tablica 14; Slika 24) pokazuju kako je sudionicima istraživanja, izvornim govornicima hrvatskoga, najzahtjevnija obrada dvosmislenih odnosnih rečenica i rečenica u kojima je ostvareno vezivanje na $\mathrm{N} 2(\mathrm{M}=6616,16 ; \mathrm{SD}=1955,39)$, a najmanje zahtjevna obrada rečenica u kojima je ostvareno vezivanje na N1. Prvi je uvjet zahtjevan upravo zbog dvosmislenosti koja se ne razrješava ni na kojem mjestu u rečenici, a drugi (vezivanje na N2) je govornicima hrvatskoga kudikamo manje prirodan od vezivanja na N1 (vidi prethodna poglavlja).

Za odnosne rečenice s imenskim skupinama u genitivnim dopunama primjećuje se sličan trend (dvosmislene rečenice s nejasnim vezivanjem: $\mathrm{M}=6053,23$; $\mathrm{SD}=1842,96 ; \mathrm{N} 1: \mathrm{M}=5912,83$; $\mathrm{SD}=1936,35 ; \mathrm{N} 2: \mathrm{M}=6241,28 ; \mathrm{SD}=1882,60)$, ali on ne dostiže statističku značajnost. Razlog leži u činjenici da su odnosne rečenice s vezivanjem na N2 sudionicima istraživanja bile u sličnoj mjeri zahtjevne kao i dvosmislene odnosne rečenice.

Razlike između uvjeta u kojima je ostvareno vezivanje na N1 i onih u kojima je ostvareno vezivanje na N2 (bez obzira na vrstu imenske skupine) detaljno su izložene u prethodnim poglavljima, a grafički prikaz u nastavku dodatno dočarava koliko je vezivanje na N1

\footnotetext{
${ }^{47}$ Cohenov $d=0,31$
} 
govornicima hrvatskoga prirodnije od oba preostala uvjeta (Slika 24).

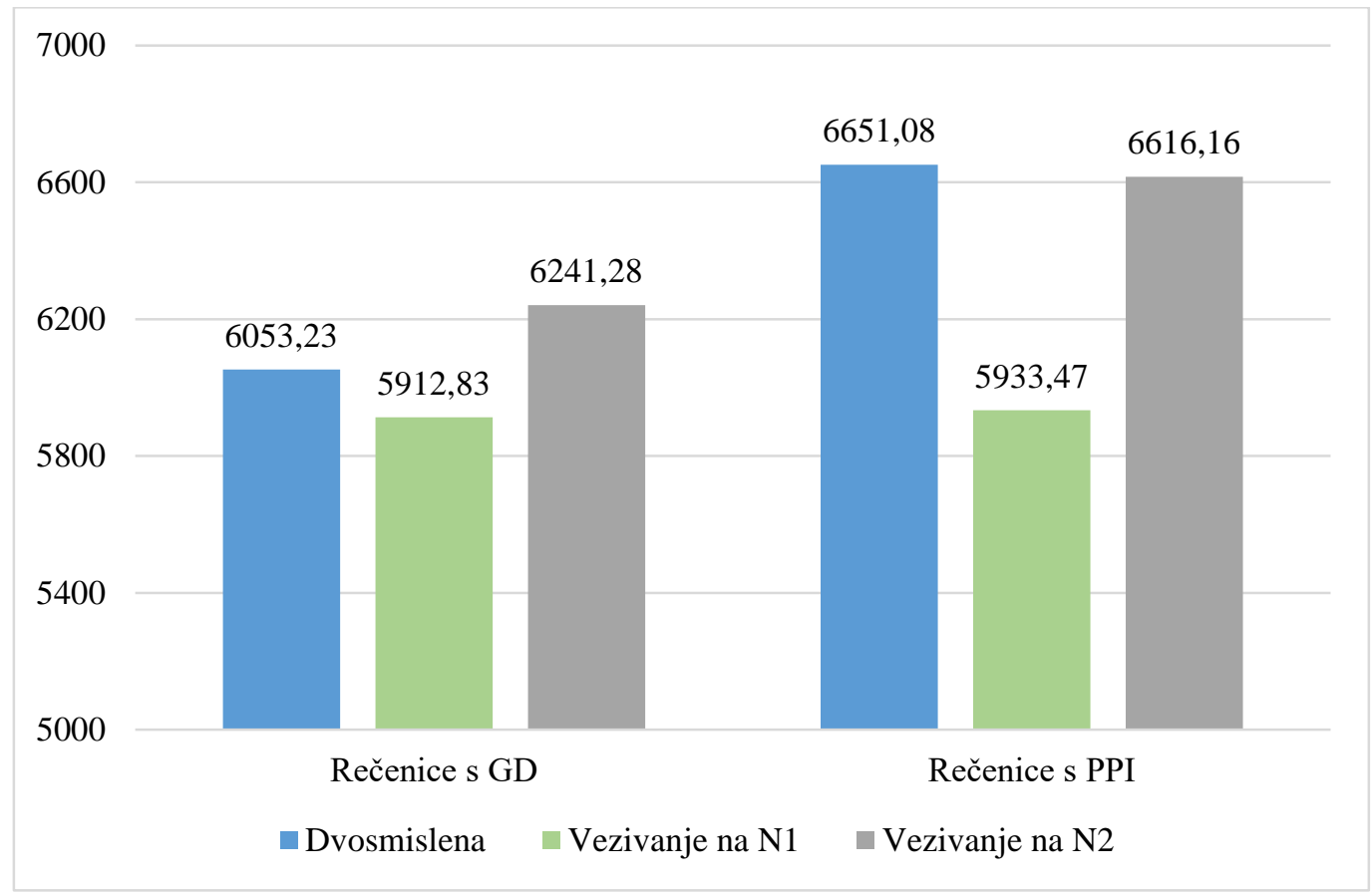

Slika 24. Prikaz ukupnih vremena čitanja (ms) za obje vrste odnosnih rečenica (različita vrsta NP; GD i PPI) u trima uvjetima vezivanja.

Iste su usporedbe ( $t$-test) provedene i na kvantitativnim rezultatima drugog eksperimenta $\mathrm{u}$ stvarnom vremenu, ponajprije radi dodatne potkrjepe opažene tendencije za porastom obradbenih zahtjeva prilikom čitanja dvosmislenih odnosnih struktura. Porast obradbenih zahtjeva očituje se produljenim vremenom čitanja, na taj način upućujući na postojanje kompeticije više razina obavijesti koje posljedično inhibiraju pravovremenu interpretaciju iskaza.

Ponovno su na varijabli ukupno vrijeme čitanja međusobno uspoređene dvosmislene odnosne rečenice s rečenicama u kojima je ostvareno vezivanje na N1 i na N2, i to u obama uvjetima; onome u kojem se surečenica odnosi na antecedent s obilježjem živo i onome u kojem se odnosi na antecedent s obilježjem neživo.

Rezultati $t$-testa pokazuju kako su sudionici $(N=48)$ statistički značajno više vremena provodili čitajući dvosmislene odnosne strukture u kojima antecedenti imaju obilježje živo $(\mathrm{M}=6747,22$; $\mathrm{SD}=2445,68)$ nego iste odnosne strukture u kojima je ostvareno vezivanje na N1 (M=5801,45; 
$\mathrm{SD}=1497,09)\left(t=3,80 ; p=0,000^{48}\right)$. Razlike između dvosmislenih struktura i onih u kojima je ostvareno vezivanje na N2 (M=6340,25; SD=1926,10) u uvjetu živo ne dostižu statističku značajnost, što je još jedan pokazatelj da je govornicima hrvatskoga uvjet vezivanja na N2 u najmanju ruku jednako obradbeno zahtjevan kao dvosmislena struktura. Drugim riječima, to je još jednim dokazom da govornici nesvjesno očekuju da će odnosna surečenica modificirati prvi antecedent, tj. glavu imenske skupine, posebice ako on ima obilježje živo. Takve su strukture manje zahtjevne od obje preostale vrste odnosnih struktura.

Detaljna je usporedba vremena čitanja odnosnih struktura u kojima je ostvareno vezivanje na N1 s obilježjem živo naspram onih u kojima je ostvareno vezivanje na N2 s istim obilježjem opisana u prethodnim poglavljima, a grafički prikaz u nastavku to dodatno dočarava (vidi vrijednosti grafova na Slici 25).

Značajne razlike između dvosmislenih i nedvosmislenih struktura (N1 i N2) nisu utvrđene u uvjetima u kojima je ostvareno vezivanje na antecedent s obilježjem neživo. Sudionici su takve rečenice u sva tri uvjeta čitali podjednako dugo (dvosmislene rečenice s nejasnim vezivanjem: $\mathrm{M}=6539,69 ; \mathrm{SD}=2092,74 ; \mathrm{N} 1: \mathrm{M}=6244,56 ; \mathrm{SD}=1846,66 ; \mathrm{N} 2: \mathrm{M}=6346,40 ; \mathrm{SD}=1985,31$ ). Donekle su kraća vremena ponovno zabilježena u uvjetu vezivanja na N1, što je dodatna potvrda da je ta struktura govornicima hrvatskoga najmanje zahtjevna za obradu, tj. da im je intuitivnija i prirodnija. Srednje vrijednosti pokazuju i značajno produljeno vrijeme čitanja tih struktura u odnosu na one u kojima je ostvareno vezivanje na antecedent s obilježjem živo, neovisno o njegovu položaju u imenskoj skupini (Tablica 18; Slika 25).

Konačno, usprkos tomu što statistička značajnost nije dostignuta, na Slici 25 primjećuju se veće vrijednosti, tj. produljena vremena čitanja dvosmislenih struktura, u odnosu na preostale dvije nedvosmislene vrste struktura (vezivanje na N1 i N2).

\footnotetext{
${ }^{48}$ Cohenov $d=0,47$
} 


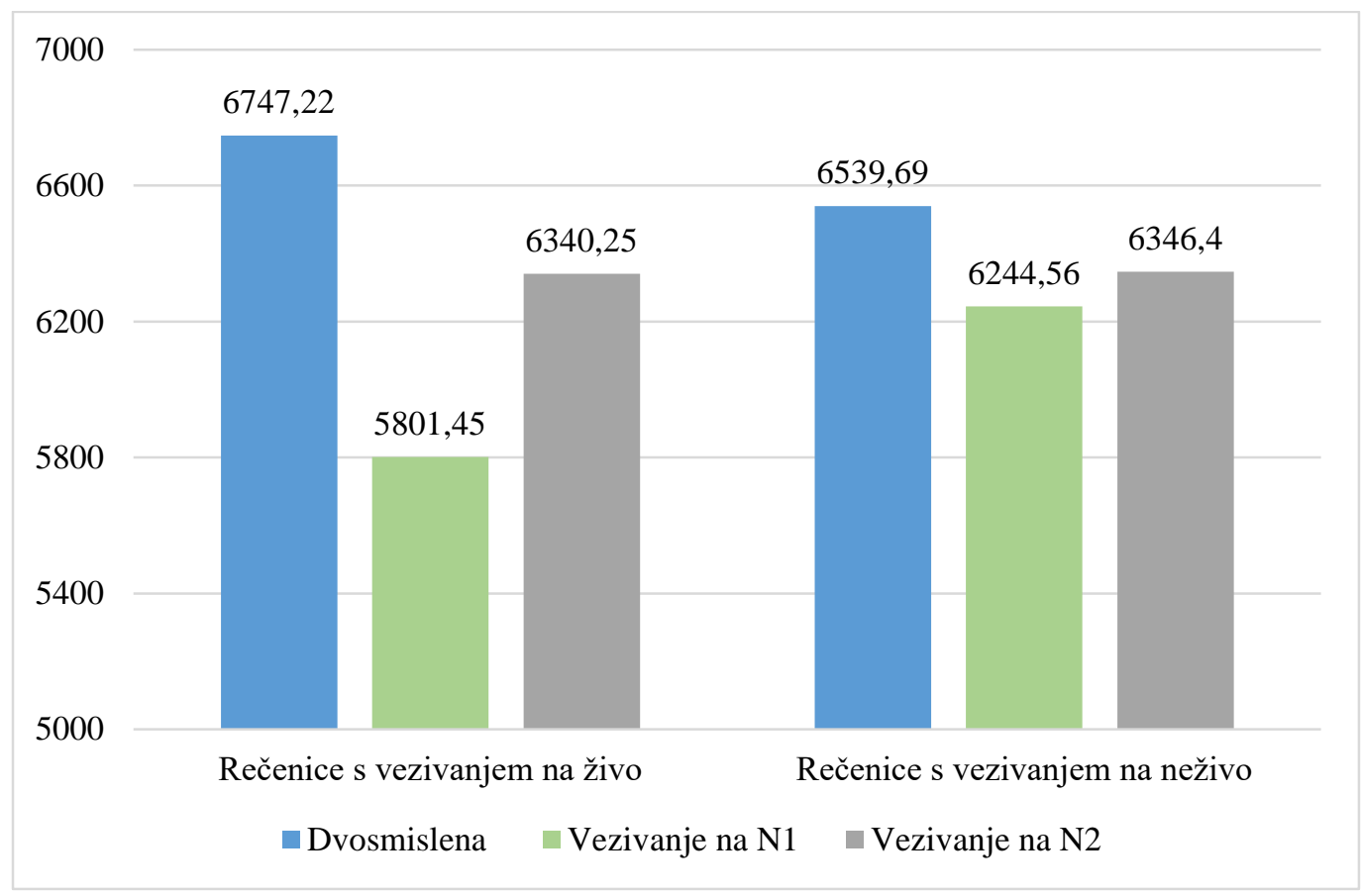

Slika 25. Prikaz ukupnih vremena čitanja (ms) za obje vrste odnosnih rečenica (različita obilježja živosti; živo i neživo) u trima uvjetima vezivanja. 


\subsection{Spoznaje u općem psiholingvističkom i jezično-specifičnom kontekstu}

U ovome će se poglavlju povesti opća rasprava, tj. svi će se dobiveni rezultati objediniti i dovesti u vezu sa psiholingvističkim modelima obrade (ponajprije ishodišnim), kao i s prethodno provedenim istraživanjima preferencija vezivanja. Naposljetku će ih se staviti u kontekst hrvatskoga jezika, kako bi proces psiholingvističkog istraživanja bio potpun, a spoznaje omogućile doprinos općelingvističkom, ali i jezično-specifičnom kontekstu (vidi Sliku 1 u poglavlju 1.2. Osvrt i motivacija za istraživanjem).

Poglavlje započinje argumentima koje govore u prilog međuovisnosti razina sintaktičke obrade, a završava osvrtom na preferencije vezivanja u hrvatskome s obzirom na konstrualnu hipotezu i obilježja hrvatskih struktura.

\subsubsection{Međuovisnost razina sintaktičke obrade}

Rezultati provedenih eksperimenata predstavljeni $\mathrm{u}$ prethodnim poglavljima $\mathrm{u}$ općem psiholingvističkom kontekstu donose nekoliko vrijednih spoznaja. Prilikom tumačenja dvosmislenih odnosnih rečenica u kojima postoji jednaka mogućnost vezivanja na oba antecedenta u složenoj imenskoj skupini, govornici hrvatskoga značajno češće odabiru prvi (vidi i Lovrić i Fodor, 2000; Lovrić, 2003; Matić, 2018). Preferencija vezivanja na udaljeniji antecedent (N1) u sličnim je istraživanjima potvrđena primjerice u nizozemskome (Brysbaert i Mitchell, 1996; Mitchell i sur., 2000), njemačkome (Hemforth i sur., 1998; 2000a; 2015), grčkom (Papadopoulou i Clahsen, 2003; Papadopoulou, 2006) i španjolskome jeziku (Cuetos i Mitchell, 1998; Dussias, 2003).

Osim toga, rezultati ispitivanja u stvarnom vremenu pokazali su produljeno vrijeme čitanja dvosmislenih odnosnih rečenica u usporedbi s onima u kojima je eksperimentalno kontrolirano vezivanje i na prvi i na drugi antecedent u složenoj imenskoj skupini (vidi poglavlje 11.4. Usporedba obrade dvosmislenih i nedvosmislenih rečenica). To je jedan od dokaza da se u nedostatku jasno izraženih ključeva u jeziku (posebice morfoloških u hrvatskome; Mimica i sur., 1994; Kuvač Kraljević, 2008) govornici oslanjaju na sve što im je dostupno, a što je izglednije u tome jeziku i danome kontekstu. Ako pak u rečenici nisu dostupni ni spomenuti ključevi ni kontekstni čimbenici (što je slučaj u dvosmislenim rečenicama), dolazi do međusobnog nadmetanja, tj. kompeticije svih razina obavijesti, a na što upućuje upravo produljeno vrijeme čitanja struktura u kojima su dvije interpretacije jednako izgledne. Iako je 
ovo istraživanje prvenstveno bilo usmjereno na ispitivanje konkretnih preferencija koje govornici imaju prilikom tumačenja odnosnih struktura, dobiveni su rezultati vrijedni u općem kontekstu istraživanja jezične obrade jer potvrđuju kompeticiju različitih razina obavijesti koje, dostupne u rečenici ili ne, izvorni govornici jezika aktiviraju paralelno (Swets i sur., 2008).

Dobiveni rezultati o obradbenim zahtjevima u slučaju dvosmislenosti, kao i oni o jasnim preferencijama koje se kose s takozvanim univerzalnim mehanizmima obrade, dodatno osnažuju spoznaje da sintaktička obrada nije beziznimno predvođena principima lokalnosti, blizine ili recentnosti (primjerice, Frazier, 1979; Gibson, 1998), već da su govornici itekako osjetljivi i na nestrukturna obilježja, poput odnosa složenih imenskih skupina koje prethode odnosnoj surečenici ili načina izražavanja relevantnih obavijesti u jeziku. U prilog tomu govore i izjave sudionika provedenog istraživanja iz kojih se jasno iščitavaju raznolikost i međudjelovanje utjecajnih čimbenika koji su se pokazali odlučujućima prilikom ispunjavanja upitnika sastavljenog isključivo od dvosmislenih rečenica. Prepoznati su strukturni, ali i prozodijski te obavijesni čimbenici na koje su se govornici oslanjali kako bi si olakšali interpretaciju i odabir, što je ponovno u skladu s interaktivnim modelima sintaktičke obrade (primjerice, MacDonald i sur., 1994; ali vidi i Swets i sur., 2008). U nedostatku konteksta govornici se oslanjaju na sve dostupne resurse u jeziku. Što je tih resursa manje, pretraga je dugotrajnija, zbog čega se konačna interpretacija inhibira do trenutka u kojem jedna ili druga obavijest ne odnesu prevagu.

Valja naglasiti da su i metodološke odluke donesene prilikom odlučivanja o mjerama koje će se analizirati i načinu na koji će se provesti statistička analiza otvorile put dodatnim vrijednim spoznajama. Naime, istraživanjima u stvarnom vremenu dobiveni su jaki efekti i na mjerama koje odražavaju stabilne, tzv. kasnije procese obrade (ukupno trajanje fiksacija u regiji interesa ili ukupno vrijeme čitanja rečenice) i na mjerama kojima se izražavaju tzv. raniji procesi (primjerice, prvi prijelaz). Efekti na ranim mjerama pokazatelji su da do prekida ili teškoća u obradi dolazi vrlo rano, čim čitatelj prvim pogledom obuhvati dijelove koji se kose s njegovim predviđanjima i inicijalnim preferencijama (u ovome istraživanju, u uvjetima eksperimentalne manipulacije vezivanja na drugi element skupine). To dodatno pokazuje da se jezična obrada odvija inkrementalno, zbog čega smo u stanju gotovo trenutačno uočiti (ne)strukturne nepravilnosti ili neusklađenosti između onoga što kao govornici jezika očekujemo i onoga s čime smo suočeni. Do jednakih se spoznaja o brzini sintaktičke obrade došlo različitim istraživanjima jezične obrade u drugim jezicima, primjerice u francuskome (Zagar i sur., 1997), engleskome (Traxler i sur., 1998; Pickering, Traxler i Crocker, 2000; Staub, 2007), turskome 
(Kaya, 2012) itd., također prvenstveno zbog jakih efekata na ranim mjerama zabilježenima mjerenjem pokreta oka.

\subsubsection{Preferencije vezivanja u hrvatskome: osvrt na konstrualnu hipotezu i osobitosti ispitanih struktura}

Temeljni je cilj ovoga rada bio utvrditi preferencije govornika u tumačenju odnosnih struktura s različitim vrstama složenih imenskih skupina. Ishodišna konstrualna hipoteza predviđa različite preferencije s obzirom na strukturna i značenjska obilježja imenskih skupina koje prethode odnosnoj surečenici, što Frazier i Clifton $(1996 ; 1997)$ objašnjavaju mnogobrojnim mogućnostima izražavanja odnosa $\mathrm{u}$ imenskim skupinama $\mathrm{s}$ besprijedložnim i prijedložnim dopunama te njihovim mogućim utjecajem na promjenu fokusa govornika. Nije potrebno ponavljati važnost i manjkavosti ove hipoteze (oni su izneseni ranije u disertaciji), ali valja se osvrnuti na rezultate svih triju provedenih eksperimenata i dovesti ih u vezu s hipotezom.

Budući da su autori nekih ranije provedenih istraživanja prepoznali čimbenike s jasnim utjecajem na preferencije, poput duljine odnosne surečenice (zbog načina prozodijske segmentacije; Quinn i sur., 2000; Lovrić i sur., 2001; Hemforth i sur., 2015), položaja imenske skupine (Traxler i sur., 1998; Hemforth i sur., 2015) i individualnih razlika u rasponu radnoga pamćenja (Omaki, 2005; Traxler, 2007; Payne i sur., 2014), isti su se u ovom istraživanju kontrolirali, tj. držali su se konstantnima, kako bi se spriječio njihov mogući utjecaj na rezultate. Rezultati prvog istraživanja u odgođenom vremenu pokazuju vrlo jasne i visoke preferencije vezivanja na prvu imenicu. Drugim riječima, u oba uvjeta prevladava odabir prvog antecedenta bez obzira na vrstu imenske skupine (70,3\% u besprijedložnim genitivnim dopunama i čak 81,1\% u prijedložno-padežnim izrazima). Prema Frazier i Clifton (1996; 1997) prijedlozi koji pripadaju prijedložno-padežnom izrazu mogu utjecati na promjenu fokusa i preferencija govornika (prema N2) zato što nisu dijelom iste domene obrade kao glava skupine (N1). S druge strane, besprijedložne genitivne dopune najčešće pripadaju jednoj obradbenoj jedinici ili domeni, zbog čega će fokus govornika ostati na glavi skupine, tj. prvom antecedentu. Valja naglasiti da su u jezicima poput engleskoga ili španjolskoga i genitivne dopune prijedložne, ali taj prijedlog (of ili de) neće tematski označiti drugu imenicu, tj. neće utjecati na promjenu fokusa govornika.

Pretpostavke o različitim domenama obrade u tim dvama uvjetima (genitivna dopuna i prijedložno-padežni izraz) u nekim su jezicima potvrđene, primjerice u grčkome 
(Papadopoulou, 2006), francuskome i talijanskome (Frenck-Mestre i Pynte, 2000). U tim se istraživanjima prijedlogom uglavnom izražavala socijativnost ili kakvo svojstvo, a antecedenti su najčešće imali obilježje živo (profesorica sa studenticom koja). Mendelsohn i Pearlmutter (1999) u istraživanje su uvrstili i antecedente s obilježjem neživo, a u njihovim primjerima se prijedlozima izražavala statična lokacija ili lokacija blizine (haljina sa čipkom koja; trgovina blizu plaže koja). U potonjim slučajevima autori nisu potvrdili predviđanja konstrualne hipoteze. Kombinirane metode upitnika i praćenja pokreta očiju u tom istraživanju nisu pokazale promjene preferencije govornika, što je jednako rezultatima ovoga doktorskog istraživanja.

Izgledno objašnjenje oprečnih spoznaja može biti maločas spomenuta razlika u odnosima antecedenata. Primjeri u kojima je najčešće zabilježena promjena preferencije primjeri su u kojima prva imenica u prijedložno-padežnom izrazu nije nužno i glava skupine, što doprinosi donekle neutralnijem i ujednačenijem odnosu dvaju mogućih antecedenata koje modificira odnosna surečenica (profesorica i studentica iz prvog primjera; Papadopoulou, 2006). Moguće je da je u potonjim primjerima (haljina i čipka; trgovina i plaža; Mendelsohn i Pearlmutter, 1999), kao i u primjerima u ovoj disertaciji (vidi Priloge na kraju rada) odnos dviju imenica u prijedložno-padežnom izrazu kudikamo manje ujednačen, odnosno manje uravnotežen.

Na ovome je mjestu vrijedno osvrnuti se na općelingvističku teorijsku raspravu o izazovima u određivanju razlika između argumenta i adjunkta, odnosno glave i dopune u imenskim skupinama i prijedložno-padežnim izrazima. Iako je jasno da će glava kojeg izraza biti prominentnija, a posljedično i češće odabrana za antecedenta surečenice $u$ istraživanjima preferencija, ponekad je nejasno što je u takvim iskazima glava, a što dopuna. Van Valin (2001: 94) navodi da je adjunkt ili dopuna onaj dio iskaza koji može biti izostavljen bez utjecaja na cjelokupno značenje iskaza, pri čemu kao primjer navodi upravo prijedložno-padežne izraze. Usprkos tom određenju i on spornima smatra prijedložno-padežne izraze kojima se označava lokacija. U pravilu, ako prijedložno-padežni izraz u lokativu označava lokaciju kojega sudionika (subjekta), onda čitav izraz postaje argument. Ako pak označava lokaciju cijeloga događaja, najčešće je samo adjunkt ili dopuna (Van Valin, 2001: 95). Dakle, ako je izraz iz kojega god razloga u iskazu obavezan onda cijeli taj izraz može biti argument. U suprotnome se radi o dopuni, tj. neobaveznome dodatku. Složena pitanja poput ovih ipak ostaju otvorena budući da različite teorije ionako zauzimaju različita stajališta (ibid.).

Navedene se općelingvističke teorijske nedoumice o distinkciji glave i dopune u različitim vrstama složenih imenskih skupina i prijedložno-padežnih izraza mogu dovesti u vezu s 
oprečnim rezultatima eksperimentalnih istraživanja preferencija vezivanja. Moguće je da u jeziku postoji nešto zbog čega govornici po osjećaju (ne) mijenjaju preferencije, posebice u nedostatku jasnoga konteksta. U primjerima u ovoj disertaciji nije potpuno jasno je li moguće izostaviti koji dio prijedložno-padežnih izraza u imenskoj skupini bez utjecaja na značenje. Govornici hrvatskoga najčešće su čitav prijedložno-padežni izraz smatrali jedinstvenom cjelinom, a prijedlog nije utjecao na promjenu njihova fokusa. Potvrda tomu jest način na koji su u konačnici tumačili ispitane strukture, ali i način na koji su ih na nesvjesnoj razini inkrementalno obrađivali tijekom čitanja u sebi. Obavijest iskazanu na početku imenske skupine smatrali su relevantnijom i prominentnijom, a time i glavom skupine na koju se kasniji sadržaj odnosi, bez obzira je li riječ o genitivnoj dopuni ili prijedložno-padežnom izrazu.

Ove se spoznaje mogu dovesti $\mathrm{u}$ vezu $\mathrm{s}$ onim što su nakon provedenih eksperimenata $\mathrm{u}$ njemačkome jeziku problematizirali Hemforth i sur. (2000a). Među prvima su znatno veću važnost nego što je dotad bio slučaj pridali dostupnosti i prominentnosti referenata u diskursnoj jedinici, tj. utjecaju obavijesnoga na obradu i preferencije vezivanja u rečenici. Otvorenima su ostavili dvije mogućnosti: 1) da prijedlozi unutar imenske skupine mogu utjecati na preferencije samo ako doista umanjuju dostupnost prve imenice u izrazu ili da 2) čitava imenska skupina, neovisno o vrsti i prijedlogu koji može biti njezinim dijelom, čini jedan referentni izraz, tj. jednu diskursnu jedinicu. U ovome se ispitivanju provedenom u hrvatskome jeziku upravo druga mogućnost pokazala točnijom.

Doprinos se samoj konstrualnoj hipotezi stoga najviše odnosi upravo na drugu pretpostavku, odnosno na njezino opovrgavanje u hrvatskome. Naime, iako je spoznaja da vrsta strukture može odrediti preferenciju i donekle utjecati na smjer sintaktičke obrade itekako vrijedna, donošenje prečvrstih zaključaka i njihova generalizacija na temelju sporadičnih istraživanja provedenih mahom u engleskome jeziku još se jednom pokazalo pogrešnim. Bez obzira na to što se preferencije vezivanja prilikom obrade odnosnih struktura mogu promijeniti ovisno o vrsti imenske skupine (tj., ovisno o tome pripada li imenska skupina koja prethodi odnosnoj surečenici jednoj obradbenoj cjelini ili je dijelom više njih), nije ispravno tvrditi da to ovisi isključivo o prijedlogu koji je dijelom te cjeline. Naime, mnogo više čimbenika istovremeno utječe na obradu tijekom čitanja ili slušanja, a kao izvorni govornici jezika na nesvjesnoj se razini oslanjamo na različite razine obavijesti koje integriramo prilikom interpretacije iskaza.

Primjerice, ovo je istraživanje pokazalo da se govornici hrvatskoga prilikom čitanja teksta u sebi vode i prozodijskim obilježjima jezika te implicitno usvojenim pravilima segmentacije jezičnoga iskaza. Njihove izjave koje su zabilježene po završetku ispitivanja (Tablica 22) 
dodatno su pomogle rasvijetliti rezultate eksperimenata u odgođenom i u stvarnom vremenu jer su pokazale važnost prozodijskih i obavijesnih čimbenika u tumačenju ispitanih rečenica. Ovakve spoznaje govore u prilog onome o čemu se sve češće govori - sprezi i međudjelovanju prozodijskih, strukturnih i obavijesnih čimbenika koji paralelno vode jezičnu obradu, a koje je teško jasno izolirati (Hemforth i sur., 2000a; 2015; Reich, 2012; Wind Cowles, 2012; Raffaelli, 2015).

Nadalje, osim razlika u načinu vezivanja odnosne surečenice na složenu imensku skupinu u genitivnoj dopuni i na onu s prijedložno-padežnim izrazom, Frazier i Clifton $(1996 ; 1997)$ smatraju da su razlike u preferencijama moguće i među odnosnim rečenicama u kojima relativizatoru prethode imenske skupine s različitim vrstama genitivnih dopuna, ako se njima izražavaju različiti odnosi (posvojnost, gradbenost itd.; vidi i Gilboy i sur., 1995). Traxler i sur. (1998) i Papadopoulou (2006) među onima su koji upozoravaju na nedovoljno jasna određenja ove postavke konstrualne hipoteze, kao i na važnost provedbe kontroliranih istraživanja u drugim jezicima kako bi se pokušali rasvijetliti razlozi oprečnih spoznaja u tim naizgled potpuno jednakim strukturama.

U ovome su doktorskom istraživanju potvrđene vrlo jasne preferencije vezivanja na prvi element skupine, a ono što se tom imenskom skupinom izražava nije se pokazalo ključnim čimbenikom u tumačenju. Primijećena brojčana odstupanja na pojedinačnim primjerima $u$ ovom su istraživanju ovisila o obilježju živosti i načinu uvođenja N2, tj. njezinomu referencijalnom statusu.

Takvi rezultati upućuju na značajnu ulogu obavijesnoga u iskazu (položaj N1 pojačava prominentnost i relevantnost), kao i na važnost obilježja živosti koje u hrvatskome olakšava obradu. Manji troškovi obrade, tj. smanjeni obradbeni napor prilikom obrade struktura u kojima je ostvareno vezivanje na imenicu s obilježjem živo nego onih u kojima je ostvareno vezivanje na imenicu s obilježjem neživo, kao i mnogo jača snaga efekta za preferencije prema prvom antecedentu u uvjetu živo nego u uvjetu neživo u skladu su s istraživanjima u nizozemskome (Desmet i sur., 2006). I u istraživanju u tome jeziku potvrđena je preferencija vezivanja na prvu imenicu kada je ona zadovoljavala kriterij živosti, kao i statistički značajno kraće vrijeme čitanja uz manji broj regresivnih pokreta oka u uvjetima u kojima je odnosna surečenica modificirala imenicu s obilježjem živo i konkretno nego u onima u kojima je modificirala imenicu s obilježjem neživo i apstraktno. Slične spoznaje pronađene su i u ispitivanju preferencija vezivanja u turskome jeziku (Kaya, 2012). Iako je u tom istraživanju nađena 
značajna preferencija prema N2 (mjere prikupljene metodom praćenja pokreta očiju u tome su uvjetu pokazale niže vrijednosti nego u uvjetu N1), pronađen je vrlo jak efekt živosti (produljena vremena čitanja u uvjetima u kojima je ostvareno vezivanje na imenicu s obilježjem neživo).

Rezultati ovoga doktorskog istraživanja govore o važnosti položaja i živosti u sintaktičkoj obradi i kao takvi su vrijedni u jezično-specifičnom kontekstu jer se nadovezuju na ranije provedena psiholingvistička istraživanja u hrvatskome. Čini se da se govornici hrvatskoga, u nedostatku jasnih morfoloških obavijesti ( $\mathrm{tj} .$, ključeva), oslanjaju na redoslijed riječi (prvenstveno ovisno o obavijesti iskaza) i na obilježje živosti. Do takvih su spoznaja došli i Mimica i sur. (1994), iako u okviru kompeticijskoga modela i uporabom drugačije metodologije.

Rezultati preferencija govornika hrvatskoga u skladu su i s prethodnim istraživanjima vezivanja u hrvatskome, pri čemu donose i neke nove uvide (Lovrić i Fodor, 2000; Lovrić i sur., 2000; 2001; Lovrić, 2003; Matić, 2018; Matić i sur., 2019). Naime, istraživanja Lovrića i suradnika provedena su u drugačijem teorijskom okviru i primjenom drugačijih metodoloških postupaka u kojima se na različite načine manipuliralo prozodijskim obilježjima iskaza. Ispitane su strukture bile ograničene isključivo na genitivne dopune (kojima se najčešće izražavala posvojnost), a čija tvorba nije u potpunosti bila u skladu sa zakonitostima hrvatskoga jezika (primjerice, $o d+$ genitiv). Unatoč tomu autori su opetovano potvrdili preferenciju vezivanja na prvi element imenske skupine u genitivnoj dopuni, povezujući takvu preferenciju s prozodijskim obilježjima jezika i načinom na koji govornici odjeljuju (odnosne) strukture koje čuju, čitaju ili izgovaraju naglas.

Istraživanje Matić i sur. (2019) pokazalo je pak preferencije prema posljednjem elementu skupine, ali važno je naglasiti da se tim eksperimentom ispitivala obrada drugačijih struktura. Odnosnoj je surečenici naime prethodila koordinirana skupina sa značajno uravnoteženijim odnosom mogućih antecedenata, što je izgledno objašnjenje različitih preferencija (prema N2) u odnosu na preferencije koje su utvrđene u ovome radu (prema N1).

Unatoč nekim ograničenjima navedenima u radu iz 2019., vrijedno je rezultate ovih dvaju istraživanja dovesti u vezu. Naime, oba istraživanja potvrđuju da su govornici jezika itekako osjetljivi na suptilne strukturne i nestrukturne razlike u jeziku te da će one dovesti i do razlika u tumačenju iskaza unutar pojedinoga jezika. Osim toga, oba su istraživanja dala dodatan uvid 
u unutarjezične čimbenike koji vode sintaktičku obradu u hrvatskome. Prvo je navedeno istraživanje pokazalo da sročnost olakšava obradu (vidi i Willer-Gold i sur., 2016), dok je ovo doktorsko istraživanje dodatno potvrdilo i značaj živosti te obavijesnoga u iskazu. Osim toga, kontrola individualnih razlika govornika i ispitanih struktura, kao i kombiniranje mnoštva metoda u odgođenom i stvarnom vremenu, ovom su istraživanju dodatno dali na snazi. 


\section{POTVRDA PRETPOSTAVKI}

H.1. S obzirom na prvo predviđanje konstrualne hipoteze i dosadašnja istraživanja obrade odnosnih rečenica u hrvatskome, pretpostavlja se da će postojati opća preferencija vezivanja na prvu imenicu unutar složene imenske skupine u genitivnoj dopuni.

Prva se hipoteza prihvaća. Rezultati ispitivanja u odgođenom vremenu jasno su pokazali prevladavajuće preferencije vezivanja na prvu imenicu unutar složene imenske skupine u genitivnoj dopuni. Spoznaje su dodatno potkrijepljene rezultatima dvaju eksperimenata u stvarnom vremenu koji su pokazali značajno kraće vrijeme čitanja struktura u kojima je ostvarena eksperimentalna manipulacija vezivanja na prvu imenicu, u odnosu na uvjet u kojem je odnosna surečenica modificirala drugu imenicu. Dobiveni su jaki do vrlo jaki efekti na nekoliko mjera u dvjema promatranim regijama interesa, kao i na razini čitave rečenice.

H.2. S obzirom na drugo predviđanje konstrualne hipoteze, ako su imenice unutar imenske skupine povezane prijedlogom s mogućnošću tematskog označavanja i prebacivanja fokusa, pretpostavlja se da će postojati preferencija vezivanja na drugu imenicu unutar složene imenske skupine.

Druga se hipoteza ne prihvaća. Rezultati ispitivanja u odgođenom vremenu pokazali su vrlo visoke preferencije vezivanja na prvu imenicu i unutar složene imenske skupine koja je činila prijedložno-padežni izraz. Taj je rezultat dodatno potvrđen prvim eksperimentom u stvarnom vremenu u kojemu ni na jednoj relevantnoj mjeri nije pronađena interakcija koja bi upućivala na promjenu preferencija uzrokovanu navedenim čimbenikom. Prijedlog u imenskoj skupini za govornike hrvatskoga nije utjecao na promjenu fokusa, tj. nije promijenio njihove preferencije.

H.3. S obzirom na obilježja hrvatske sintakse i prethodna istraživanja, pretpostavlja se da će u nedostatku morfoloških obavijesti (ključeva) obilježje živosti olakšati sintaktičku obradu i utjecati na promjene preferencija govornika.

Treća se hipoteza djelomično prihvaća. Iako obilježje živosti nije uzrokovalo promjene preferencija vezivanja, rezultati drugog eksperimenta u stvarnom vremenu pokazali su da živost u hrvatskome može olakšati sintaktičku obradu. 


\section{ZNANSTVENI DOPRINOS I OGRANIČENJA ISTRAŽIVANJA}

Rad je prvenstveno bio usmjeren širenju spoznaja o osobitostima sintaktičke obrade, pri čemu se nastojalo zahvatiti i širi, psiholingvistički, i uži, jezično-specifični kontekst. Takav je pristup posljedica uočenih ograničenja nekih istraživanja koja su dovela do ekspanzije modela i teorija u kojima se postalo vrlo teško snaći. Naime, mnogi modeli preusko gledaju na problematiku kojoj pristupaju, zbog čega se u njihovim postavkama i istraživanjima primjećuju dvije tendencije: ili se spoznaje do kojih se došlo $\mathrm{u}$ drugim istraživanjima ne uzimaju u obzir $\mathrm{u}$ dostatnoj mjeri, ili se struktura vlastitoga jezika narušava radi poštivanja eksperimentalnoga nacrta i postavki upravo modela koji se ispituje.

Pomnom razradom ispitnih podražaja, poštivanjem osobitosti hrvatskoga jezika i uzimanjem u obzir nekih ograničenja prethodnih studija (primjerice, način kontrole nejezičnih i jezičnih varijabli), ovaj je rad omogućio unaprjeđenje načina na koji se općenito pristupa ispitivanju postavki modela sintaktičke obrade. Drugim riječima, omogućio je razumijevanje općih psiholingvističkih zakonitosti, ali i načela ustroja strukturno-značenjskih obilježja ispitanih rečenica u hrvatskome jeziku.

Do spoznaja u istraživanju došlo se dvjema metodama - u odgođenom i stvarnom vremenu - i rezultati su vrijedni iz nekoliko razloga koje sumiramo u nastavku.

U općelingvističkom i psiholingvističkom kontekstu oni

1) opovrgavaju neka predviđanja konstrualne hipoteze čime potvrđuju njezina ograničenja iznesena u kritičkim osvrtima na početku disertacije i u dijelu rasprave;

2) donekle potvrđuju interaktivne modele koji zagovaraju istovremenu aktivaciju i kompeticiju više razina obavijesti prilikom čitanja, obrade i intepretacije dvosmislenih struktura;

dok u jezično-specifičnom kontekstu

3) pokazuju da je integracija obavijesti prilikom obrade odnosnih struktura u hrvatskome prirodnija u uvjetu vezivanja na N1 nego u uvjetu vezivanja na N2. Odgovori sudionika istraživanja prikupljeni metodom upitnika upućuju na značajne preferencije prema N1, što je dodatno potkrijepljeno dvama istraživanjima u stvarnom vremenu; 
4) pokazuju da, bez obzira na položaj antecedenata u imenskoj skupini, obilježje živosti u hrvatskome olakšava obradu. Drugim riječima, ako se antecedenti u imenskoj skupini razlikuju s obzirom na obilježje živosti, obrada će biti olakšana ako odnosna surečenica koja slijedi sadržajem modificira antecedenta s obilježjem živo.

Budući da rad govori i o unutarjezičnim čimbenicima koji usmjeravaju sintaktičku obradu, a ne isključivo o čimbenicima koje se može povezati s općim mehanizmima koji su u pozadini, omogućava širenje spoznaja u kontekstu hrvatske psiholingvistike. Istraživanja o obilježjima na koje se govornici hrvatskoga oslanjaju u nedostatku jasnih morfoloških ključeva prvenstveno redoslijed riječi i živost (Mimica, 1988; Mimica i sur., 1994; Kuvač Kraljević, 2008) - bila su važna zbog oblikovanja pretpostavki i istraživačkih podražaja. Ta su se ista obilježja pokazala i kao olakšavajući, iako ne uvijek i ključni, čimbenici na koje se govornici hrvatskoga oslanjaju kako bi odredili antecedent.

Rezultati o prevladavajućem odabiru prvog antecedenta u skladu su s prethodnim istraživanjima preferencija govornika hrvatskoga, ali pokazuju da razloge ne treba tražiti samo u obilježjima prozodije hrvatskoga jezika (Lovrić i sur., 2001; Lovrić, 2003), već i u složenim odnosima strukture i značenja, kao i prominentnosti i obavijesti iskaza u hrvatskome. Spoznaja o tome da živost olakšava obradu, iako ne utječe na promjene preferencija, važan je nastavak istraživanja o utjecajnim čimbenicima koji vode obradu u hrvatskome, ponajviše sročnost (Willer-Gold i sur., 2016; Matić i sur., 2019). Rezultati ovoga doktorskog istraživanja tako dodatno poktrepljuju ono o čemu se danas sve više raspravlja, a to je međudjelovanje razina sintaktičke obrade, tj. međuodnos prozodijskih, strukturnih, kontekstnih, značenjskih i obavijesnih čimbenika koji utječu na obradu (Erteschik-Shir, 2009), a koji djeluju relativno brzo i automatski zbog čega ih nije jednostavno izolirati.

Konačno, vrijednost rada leži i u odabranoj metodologiji. Kombinacija nekoliko različitih metoda doprinijela je višeslojnosti rasprave, odnosno omogućila je pristupanje jednom problemu iz nekoliko kutova. Upitnikom u odgođenom vremenu ustanovljene su konačne preferencije govornika, dok su istraživanjima u stvarnom vremenu prikupljene one intuitivne i nesvjesne, što je zajedno omogućilo razumijevanje kasnih, tj. konačnih te ranih, tj. automatskih mehanizama obrade u samom trenutku njezina odvijanja. Izjave sudionika prikupljene po završetku istraživanja osigurale su stjecanje dodatne slike o obradi, one iz perspektive samoga 
izvornog govornika. Na taj se način iz prve ruke dobio uvid u jezični osjećaj i jezičnu intuiciju, a s druge se strane izbjegla istraživačka pristranost tijekom tumačenja rezultata (Skopeteas, 2012).

Ova disertacija dakako ima i neka ograničenja koja bi trebalo uzeti u obzir i premostiti u sljedećim istraživanjima. Iako logička pozadina uporabe isključivo odnosnih struktura $\mathrm{s}$ određenom vrstom imenskih skupina $u$ ispitnim podražajima svoje utemeljenje ima u teorijskoj podlozi razjašnjenoj u uvodnim dijelovima rada, takav pristup ima i određene negativne posljedice. Naime, koliko god vrijedni, zaključci su na ovaj način neizbježno ograničeni upravo na te vrste struktura i upitno je koliko ih se može generalizirati na neke druge. Upravo bi zato u budućim istraživanjima sintaktičke obrade trebalo težiti ispitivanju i analiziranju drugačije sintaktičke građe.

Nadalje, u ovome je radu raspon radnoga pamćenja bio kriterij kojim se uzorak sudionika istraživanja homogenizirao kako bi se isključio utjecaj individualnih razlika govornika na ustanovljene preferencije. Ipak, kako bi psiholingvističke spoznaje dodatno dobile na snazi, u sljedećim bi istraživanjima trebalo otići korak dalje i ispitati upravo utjecaj razlika u rasponu radnoga pamćenja na sintaktičku obradu, odnosno utvrditi smjer toga utjecaja. To bi moglo biti posebno važno jer su dosadašnje spoznaje u tome kontekstu ne samo drugačije, nego i potpuno oprečne (primjerice, Swets i sur., 2007; Traxler, 2007).

Konačno, sudionici istraživanja u ovome su radu - ponovno prvenstveno zbog homogenizacije uzorka - bili uredni govornici hrvatskoga jezika koju je činila mahom studentska populacija. Korisno bi bilo utvrditi i kako starija populacija ili populacija narušenoga jezičnog statusa obrađuje složene strukture, odnosno oslanjaju li se na jednake mehanizme obrade prilikom interpretacije dvosmislenih iskaza te kakve su njihove preferencije u određivanju antecedenta. Drugim riječima, razlikuju li se oni i u čemu od populacije ispitane u ovome istraživanju te kakav je obrazac i vremenski tijek sintaktičke obrade te populacije u odnosu na razmjerno mladu populaciju urednoga jezičnog statusa. 


\section{ZAKLJUČAK}

Sintaktička obrada vrlo je složeni mehanizam koji uključuje i razumijevanje i proizvodnju (Van Gompel i Pickering, 2007). Unatoč spoznajama do kojih se došlo od sredine dvadesetoga stoljeća - ponajviše zahvaljujući metodološkom napretku i porastu međujezičnih istraživanja i danas smo svjedocima brojnih neodgovorenih pitanja o čimbenicima koji utječu na sintaktičku obradu u pojedinome jeziku (Papadopoulou, 2006). Jedan od pristupa istraživanju sintaktičke obrade jest ispitivanje preferencija koje izvorni govornici imaju prilikom čitanja i tumačenja različitih struktura, a prvenstveno odnosnih rečenica. One naime dopuštaju međujezične usporedbe i omogućavaju eksperimentalnu manipulaciju s krajnjim ciljem donošenja usporedivih zaključaka o sintaktičkoj obradi (Cuetos i sur., 1996).

Dosad provedena istraživanja sintaktičke obrade i preferencija vezivanja dovela su do oprečnih spoznaja o najutjecajnijim čimbenicima koji utječu na obradu, kako među jezicima, tako i unutar pojedinih jezika, za što različite teorije nude različita objašnjenja (Mitchell i sur., 1995; Frazier i Clifton, 1996; Fodor, 2002 itd). Bez obzira na teorijski okvir i ishodišni model, danas je općeprihvaćeno da su procesi koji se odvijaju tijekom sintaktičke obrade automatski i inkrementalni te da započinju čim govornici započnu slušati ili čitati određeni iskaz ili rečenicu (Van Gompel i Pickering, 2007). Upravo je iz toga razloga jezična obrada u istraživačkom kontekstu s jedne strane zanimljiva, a s druge problematična. Naime, jasno je da oprečni rezultati proizlaze iz različitih struktura jezika, međutim nedovoljno je razjašnjeno koja ograničenja i unutarjezični čimbenici prevladavaju u pojedinome jeziku. Osim toga, eksperimentalni su nacrti provedenih istraživanja razmjerno neujednačeni, što je značajno otežalo donošenje zaključaka i generalizaciju spoznaja. Usprkos tomu što je složeno ispitati i proniknuti u prevladavajuće čimbenike koji u pojedinome jeziku usmjeravaju proces sintaktičke obrade, s vremenom je to postao jedan od glavnih ciljeva u psiholingvistici među istraživačima zainteresiranima za obradu na rečeničnoj razini (Papadopoulou, 2006; Hemforth i sur., 2015).

U kontekstu spomenutih istraživačkih tendencija, ovim se radom nastojalo ispitati o kojim strukturno-značenjskim osobitostima imenskih skupina koje prethode odnosnoj zamjenici ovise obrada i način na koji govornici tumače odnosne rečenice u hrvatskome. Prethodno je u okviru konstrualne hipoteze razrađen eksperimentalni nacrt kojim je omogućeno ispitivanje i analiziranje obradbenih procesa dvjema metodama, u odgođenom i u stvarnom vremenu. Takav je pristup osigurao stjecanje šire slike procesa obrade - ranijih, u samom trenutku njezina 
odvijanja (kako) i kasnijih, u kojima vremenski parametri obrade nisu razvidni (što). Još je jedna prednost izrađenoga nacrta ta što je njime osigurana mogućnost usporedbe triju različitih (a pritom na odgovarajući način kontroliranih) vrsta istraživačkih podražaja poradi stjecanja uvida u to odvija li se sintaktička obrada istovremeno na više razina.

Rezultati svih triju eksperimenata, kao i kvalitativnih analiza izjava nekolicine sudionika, pokazali su jasne preferencije govornika prema prvoj imenici u složenoj imenskoj skupini u hrvatskome, neovisno o tome čini li ona genitivnu dopunu (70,3\%) ili prijedložno-padežni izraz $(81,1 \%)$. Jedan je od eksperimenata pokazao i da obilježje živosti u hrvatskome olakšava obradu, a kvalitativni su rezultati dodatno potkrijepili spoznaje da se govornici prilikom tumačenja iskaza oslanjaju na višestruke razine obavijesti. Visoki obradbeni zahtjevi u slučaju dvosmislenosti razmjerno su jasan pokazatelj interaktivnosti u sintaktičkoj obradi, to jest tijekom tumačenja iskaza.

Objedinjeni rezultati proizašli iz ove disertacije potvrdili su prvu, ali opovrgnuli drugu postavku konstrualne hipoteze. Drugim riječima, pokazali su da, iako strukturno-značenjske osobitosti iskaza svakako utječu na obradu na rečeničnoj razini, složene jezične fenomene nije potrebno generalizirati i nastojati ograničiti na pretpostavke koje djeluju poput kakvih formula. Jezični je sustav kudikamo složeniji, a način na koji ga pojedinci obrađuju i razumiju ovisi o više čimbenika. Važnu ulogu imaju strukturno-značenjske osobitosti iskaza, prozodija, ali i način izražavanja obavijesti. Sve se to razlikuje od jezika do jezika i od struktura do struktura, a ne treba zanemariti i individualne razlike govornika.

Ova se disertacija svojim spoznajama naslanja na studije čiji autori u konačnici zaključuju da u nastojanju traženja odgovora i širenja spoznaja o jezičnoj obradi treba težiti ispitivanju građe specifične za jezik u kojemu se istražuje, a pritom u najvećoj mjeri eliminirati istraživačku pristranost te $\mathrm{u}$ obzir uzeti što je moguće više spoznaja, neovisno o polazišnomu psiholingvističkom modelu (primjerice, Hemforth i sur., 2015). Doista, jedino se na taj način može doprinijeti izgradnji cjelovite slike jezične obrade, ako je tako nešto uopće moguće. 


\section{POJMOVNIK}

\section{Area of interest - Područje / zona / regija interesa}

U istraživačkim metodama (poput metode praćenja pokreta očiju) pojam kojim se označava najvažnije područje unutar određenoga podražaja koje se promatra, snima i kasnije analizira. Može se odnositi na sliku u nizu slika ili na riječi u rečenici koje su od posebnoga značaja s obzirom na cilj i istraživačko pitanje. Regija interesa nije mjera sama po sebi, već se isključivo odnosi na područje na koje će se odgovarajuće mjere analize u daljnjim postupcima primijeniti. Primjerice, ako se tijekom snimanja pokreta očiju osobi na zaslonu računala pokaže slika, u programu za daljnju analizu moguće je na slici izdvojiti izolirane regije interesa te uspoređivati koliko je osoba promatrala koju regiju (zonu) i u kojem uvjetu, koliko je vremena prošlo od pojave slika do trenutka kad je osoba pogledala upravo tu ciljanu regiju ili koliko je puta vraćala pogled na nju.

\section{Attachment preference - preferencije vezivanja}

U istraživanjima sintaktičke obrade pojam kojim se označava mogućnost tumačenja rečeničnih struktura na način da se surečenica koja se trenutno obrađuje vezuje na linearno bliži ili dalji, odnosno na hijerarhijski viši ili niži antecedent. Vezivanje stoga može biti lokalno i nelokalno (linearno bliže ili dalje; izv. eng. local vs nonlocal attachment preference) ili pak više i niže (s obzirom na hijerarhijsku strukturu; izv. eng. high vs low attachment preference).

\section{Competition (during processing) - kompeticija (nadmetanje) u sintaktičkoj obradi}

Pojam kojim se donekle označavaju interaktivnost i paralelnost u obradi, odnosno istovremeno pristupanje višestrukim - i strukturnim i značenjskim - razinama obavijesti. Pritom se, u slučaju raznolikih mogućnosti interpretacije određenoga jezičnog izraza, strukturna i značenjska razina sukobljavaju. Drugim riječima, u umu govornika dolazi do kompeticije te će naposljetku prevladati ona interpretacija rečenice koja je izglednija s obzirom na različite čimbenike (čestotnost u jeziku, prethodno jezično iskustvo govornika jezika, prozodijska obilježja pojedinoga jezika, enciklopedijsko znanje govornika određene jezične i kulturne zajednice...). 
$\mathrm{Na}$ ovome se temelji čitava teorija i njoj pripadajući model jezične obrade nazvan kompeticijskim modelom. Odnosi se na dinamično povezivanje formi i funkcija u procesu razumijevanja i proizvodnje. Natjecanje ili sukobljavanje razina služi pojačavanju onih veza između ključeva koje će rezultirati uspješnim razumijevanjem i proizvodnjom (MacWhinney, 1987). Kada se ključevi slažu i međusobno podupiru, jezična je obrada olakšana (ključevi konvergiraju). Kada se ključevi ne slažu (kada su u sukobu ili natjecanju), obrada je inhibirana.

\section{Completion task - zadatak dovršavanja}

Zadatak dovršavanja zadatak je koji pripada skupini zadataka prosudbe (vidi judgement task), a nalikuje polustrukturiranom upitniku otvorenoga tipa. U psiholingvističkim istraživanjima jezične obrade ovu vrstu zadatka odlikuje veća mogućnost aktivnog sudjelovanja sudionika istraživanja jer mu odgovor nije unaprijed ponuđen. Može se odnositi na zadatak dovršavanja riječi, rečenica ili većih diskursnih cjelina. Ovako se postavljenim zadatkom može pristupiti prvom, automatskom i intuitivnom odgovoru govornika jer mu se isti ne sugerira, ali se ujedno riskira da odgovor neće biti u skladu s onime kamo istraživanje smjera.

\section{Constraint-based theory - teorija utemeljena na ograničenjima}

Teorija utemeljena na ograničenjima (MacDonald i sur., 1994) jedna je od teorija sintaktičke obrade čija je ključna pretpostavka da su sve moguće interpretacije rečenica istovremeno dohvatljive u jednakoj mjeri, a prevladat će ona koja je u skladu s više različitih izvora obavijesti kao što su čestotnost riječi, diskursni čimbenici i kontekst. Prema teoriji govornik se prilikom jezične obrade oslanja na jasna pravila i ograničenja u jeziku, kako bi mu konačno tumačenje rečenice bilo dohvatljivo. Ova ograničenja uključuju gramatičko znanje, leksička obilježja riječi u rečenici, rečenični i izvanrečenični kontekst te prethodno iskustvo govornika jezika (n.b. pojam ograničenje u ovim se teorijama može smatrati istovjetnim pojmu pravilo jer označava dopuštene granice određenih postavki teorije; vidi i Katunar, 2015: 99).

\section{Construal hypothesis - konstrualna hipoteza}

Ova hipoteza (Frazier i Clifton, 1996) polazi od pretpostavke da na različit način obrađujemo takozvane primarne i neprimarne strukture. Prema tvorcima hipoteze primarne se strukture (kakve su, primjerice, jednostavne rečenice) obrađuju na jednak način u svim jezicima, odnosno 
njihova je obrada vođena univerzalnim načelima. S druge pak strane, obrada je neprimarnih struktura (kakve su složene strukture poput odnosnih rečenica) vođena složenijim pravilima koja ne podliježu univerzalnim načelima, stoga pozadinske mehanizme obrade u pojedinim jezicima tek predstoji istražiti.

U kontekstu istraživanja preferencija vezivanja, konstrualna hipoteza odlučujućim čimbenicima u sintaktičkoj obradi smatra strukturno-značenjska obilježja odnosnih rečenica. Drugim riječima, preferencije vezivanja u okviru ove pretpostavke ovise ponajviše o strukturnoznačenjskim osobitostima i odnosima imenica unutar imenske skupine koja prethodi odnosnoj surečenici. U skladu s time preferencije vezivanja variraju među jezicima, kao i unutar pojedinoga jezika, jer su i načini izražavanja odnosa u imenskim skupinama različiti.

\section{Cue - ključ}

Pojam koji se odnosi na bilo koji dio jezične obavijesti koji slušatelj ili govornik može upotrijebiti (ili se na nju osloniti) radi interpretacije rečenice, odnosno tumačenja njezina značenja. Prema tome se ključ može odnositi i na strukturnu i na značenjsku razinu. Slušatelj ili čitatelj se prilikom razumijevanja oslanja na ključeve poput redoslijeda riječi, leksičkosemantičkoga ključa živosti, morfoloških nastavaka i prozodijskih obilježja s ciljem dohvaćanja značenja. Navedeni ključevi upućuju na činjenicu da se prilikom obrade istovremeno oslanjamo na ključeve koji pripadaju različitim jezičnim sastavnicama. Koji će ključ biti presudan u interpretaciji iskaza ovisi o jakosti i valjanosti ključeva, a što varira među jezicima.

\section{Eye-mind assumption - pretpostavka oko-um}

Pretpostavka o povezanosti kognitivnih procesa $\mathrm{s}$ trenutnim predmetom fokusa (Just i Carpenter, 1980). Prema ovoj pretpostavci postoji izravna veza između onoga u što osoba trenutno gleda i na što misli, tj. što u umu obrađuje, čime se fiziološka razina kontrole pokreta oka povezuje s kognitivnim procesima koji su u pozadini. Iako je pretpostavka dokazana te se na njoj velikim dijelom i temelje istraživanja jezične obrade praćenjem pokreta očiju, sporna je tvrdnja koja neizravno slijedi iz pretpostavke - da obrada završava u trenutku u kojem određeni predmet, vizualna scena ili jezična struktura nestaju iz izravnoga fokusa i vidnoga polja osobe. 


\section{Experimenter bias - istraživačka pristranost}

Pojam koji se odnosi na proces tijekom istraživanja u kojem osoba koja ga provodi utječe na rezultate kako bi izazvala željeni ishod. To se može odnositi na:

a) teorijsku pristranost, pri čemu istraživač istraživačkim nacrtom svjesno pogoduje dokazivanju teorijskih postavki;

b) pogreške u istraživanju do kojih dolazi jer istraživač ne kontrolira sve varijable koje mogu utjecati na rezultate;

c) pristranost u odabiru sudionika ili prikupljanju podataka, odnosno odabir određene populacije ili metode dohvaćanja odgovora s ciljem dobivanja željenih rezultata.

Iako je u mnogim znanstvenim disciplinama određeni stupanj pristranosti nemoguće izbjeći, prilikom planiranja istraživačkoga nacrta potrebno je iste biti svjestan, svesti ju na najmanju moguću razinu te se na nju osvrnuti prilikom interpretacije rezultata.

\section{Eye-tracking - praćenje pokreta očiju}

Metoda u stvarnom vremenu čijom se uporabom automatski mjere i bilježe podatci o pokretima očiju osobe prilikom a) promatranja određenoga vizualnog podražaja (tijekom istovremenoga slušanja jezičnog podražaja) ili b) promatranja teksta (tijekom čitanja). Podatci omogućavaju uvid u tijek procesa u pozadini jezične obrade - mjerenjem duljine zadržavanja na pojedinom mjestu na slici ili u riječi, bilježenjem broja pokreta očiju u suprotnome smjeru ili brzine kojom osoba okom prelazi preko slikovnoga ili tekstualnog podražaja. Logička se pozadina ove metode temelji na činjenici da pokreti oka osvjetljavaju kognitivne procese. Pogodna je za ispitivanje osoba svih životnih dobi i neinvazivna je. Najpoznatije su paradigme kojima se ispituje jezična obrada i kojima se mogu osvijetliti jezični i pozadinski kognitivni procesi takozvana paradigma vizualnoga svijeta i paradigma čitanja. Paradigma vizualnoga svijeta (izv. eng. visual world paradigm) podrazumijeva istovremeno slušanje jezičnoga podražaja $i$ promatranje vizualnoga sadržaja. Pogodna je za ispitivanje mlađe i starije populacije jer je jednostavna, ne podrazumijeva meta-kognitivne zadatke, ne traži razvijenu pismenost, najčešće ne opterećuje radno pamćenje i potpuno je sigurna.

Praćenje pokreta očiju u čitanju, tj. obrada pisanoga teksta također se temelji na postavkama kognitivne psihologije prema kojima pokreti oka tijekom čitanja predstavljaju pozadinske kognitivne procese. Pokreti oka naime odražavaju interakciju strukturnih i značenjskih procesa 
obrade na leksičkoj razini (prepoznavanje pojedinačnih riječi i njihova integracija u jezični kontekst), kao i naknadnih procesa obrade na sintaktičkoj razini.

\section{Filler stimulus - umetnuti podražaj}

Umetnuti je podražaj onaj koji se namjerno umeće između eksperimentalnih podražaja, kako bi se sudioniku istraživanja odvratila pažnja od konkretnog istraživačkog cilja i kako bi se izbjeglo odgovaranje po navici ili očekivanju. Umetnuti podražaji mogu biti i dijelom drugog istraživačkog pitanja, ako oba dozvoljavaju jednaku metodologiju, a ujedno su dovoljno različita da ih se ne može dovesti u vezu. Na ovaj se način odjednom može prikupiti više podataka predviđenih za različite analize. Najčešća je svrha tih podražaja ipak samo odvraćanje pažnje sudionika istraživanja. Idealno je da se umetnuti podražaji međusobno slični te da se ni od eksperimentalnih ne razlikuju u prevelikoj mjeri. U suprotnome sudionik može zaključiti koji je podražaj ciljani, posebice ako je eksperiment dugotrajan.

\section{Forced-choice questionnaire - upitnik prisilnog odabira}

Upitnik prisilnog odabira strukturirani je upitnik zatvorenoga tipa (s više mogućih odgovora) i kao takav pripada skupini zadataka prosudbe (vidi judgement task). Zadatak s upitnikom ovakvoga tipa predstavlja jednu od najčešćih metoda dohvaćanja odgovora u (bihevioralnim i eksperimentalnim) psiholingvističkim studijama. Prednost je ovih zadataka bolja mogućnost kontrole načina na koji sudionici odgovaraju te jednostavnija analiza njihovih odgovora, a nedostatak je veći rizik da će osoba odgovarati po slučaju te sužavanje raspona mogućih odgovora čime se donekle ograničava uvid u spoznaje o problematici koja se istražuje.

\section{Garden path model - model vijugavoga puta}

Ovaj se model smatra najutjecajnijim modularnim modelom još od 70-ih godina prošloga stoljeća. Prema njegovim postavkama strukturna i nestrukturna razina jasno su odijeljene, i to na način da sve nestrukturne obavijesti (značenjska obilježja, kontekst, čestotnost uporabe oblika) postaju dostupne za obradu tek nakon što je prva razina obrade (struktura, položaj sastavnica) dovršena (Frazier i Fodor, 1978; Frazier, 1979). Prednost strukture nad značenjem tumači se načelima minimalnoga vezanja (izv. eng. minimal attachment) i kasnoga zatvaranja (izv. eng. late closure) koja su navodno univerzalna, odnosno svojstvena svim jezicima. 
Zamjerka je modelu što se usmjerava na uske aspekte jezične obrade i na taj način zanemaruje brojne druge čimbenike koji mogu utjecati na obradu. Druga je zamjerka što su se ispitivanja modela dugo temeljila na strukturama svojstvenima isključivo engleskome jeziku, zbog čega su se spoznaje neutemeljeno prihvaćale kao univerzalna istina. Porastom broja međujezičnih istraživanja u sve ga se većoj mjeri napušta, iako je i danas vrlo utjecajan te ga se u istraživanjima opetovano i dokazuje i opovrgava.

\section{Garden path effect - učinak vijugavoga puta}

U psiholingvističkim istraživanjima (najčešće onima $u$ stvarnom vremenu), pojam kojim se označava da je govornik iskusio teškoće u obradi određenoga jezičnog izraza ako on svojom strukturom ne odgovara postavkama modela vijugavoga puta. Učinak se dokazuje, primjerice, produljenim vremenom čitanja upravo onih dijelova rečenice koji nisu u skladu s postavkama navedenoga modela i njemu pripadajućih načela.

\section{Global ambiguity - potpuna dvosmislenost}

Pojam kojim se označava da je neki jezični izraz u potpunosti dvosmislen, odnosno da ni u jednome dijelu rečenice ili duljeg iskaza dvosmislenost nije razriješena. Govornik se stoga, tijekom obrade u potpunosti dvosmislenih iskaza, ne može osloniti ni na prethodno iskustvo ni na jezično ili enciklopedijsko znanje. U takvim je iskazima dvosmislenost prisutna i nakon čitanja ili slušanja, a često se ne može jednostavno razriješiti niti ponovnim čitanjem ili slušanjem. Potpuno dvosmisleni iskazi razmjerno su učestali u eksperimentalnim uvjetima i podražajima, posebice u izoliranim rečenicama, dok se u svakodnevnoj komunikaciji svjesno (ali i nesvjesno) izbjegavaju i vrlo su rijetki. Naime, sama komunikacijska situacija najčešće ne dozvoljava višestruku interpretaciju iskaza, i to zbog jasnih morfoloških i prozodijskih obilježja, teme razgovora, jezičnoga i nejezičnoga konteksta, enciklopedijskoga znanja i drugih čimbenika koji govorniku služe kao resursi na koje se mogu osloniti i tako olakšati interpretaciju.

\section{Immediacy assumption - pretpostavka neposrednosti}

Jedna od pretpostavki o jezičnoj obradi i njezinoj izravnoj vezi s kognitivnim procesima, a koja svoje utemeljenje ima u kognitivnoj psihologiji (Just i Carpenter, 1980). Prema pretpostavci 
neposrednosti riječ je glavna jedinica obrade, a govornik (primjerice, čitatelj) obrađuje upravo onu riječ koju trenutno fiksira pogledom. Ta je pretpostavka u uskoj vezi s pretpostavkom okoum (vidi eye-mind assumption).

\section{Implicit prosody hypothesis - hipoteza implicitne prozodije}

Hipoteza implicitne prozodije (Fodor, 2002) temelji se na pretpostavci da prozodijska obilježja jezika uvjetuju sintaktičku obradu i način na koji govornik obrađuje pojedine rečenične strukture. Prema postavkama ove hipoteze govornik će se u obradi, posebice tijekom čitanja naglas ili u sebi, voditi implicitno usvojenim prozodijskim obilježjima vlastitoga jezika. Ta će pravila utjecati na njegovu strukturnu segmentaciju, to jest na odjeljivanje i grupiranje riječi koje su dijelovima jezičnoga iskaza, a posljedično i na samo tumačenje.

\section{Judgement task - zadatak prosudbe}

Zadatci prosudbe skupina su zadataka koji se najčešće primjenjuju u bihevioralnim istraživanjima u odgođenom vremenu. Ipak, mogu se kombinirati i s metodama u stvarnom vremenu ukoliko takav eksperiment sadrži pitanja nakon podražaja tijekom izvedbe koja se snima. Zadatci prosudbe obuhvaćaju zadatke prosudbe istinitosti određene tvrdnje, zadatke prosudbe stupnja gramatičnosti određenog iskaza, zadatke odabira između nekoliko ponuđenih mogućnosti (upitnike prisilnog odabira) te zadatke dovršavanja.

\section{Late closure - načelo kasnoga zatvaranja}

Načelo kasnoga zatvaranja jedno je od dvaju načela modularnoga modela vijugavoga puta. Ovo načelo podrazumijeva da se nove riječi u strukturi uvijek vežu na posljednju surečenicu ili frazu, odnosno na riječ koja se trenutno obrađuje (Frazier i Fodor, 1978; Frazier, 1979). Takva se pojava uvriježeno naziva učinkom lokalnosti (izv. eng. locality effect). Ako struktura rečenice ipak nije u skladu s onime što postavke načela nalažu, predviđa se nastanak teškoća u obradi. Načelo je oblikovano uzimajući u obzir ograničenja raspona radnoga pamćenja govornika jer predmnijeva interpretaciju koja je najmanje zahtjevna za obradu. 


\section{Local/low attachment preference - lokalna/niža preferencija vezivanja}

U kontekstu studija preferencija vezivanja, pojam kojim se označava da se u pojedinome jeziku rečenične strukture tumače na način da se fraza, tj. surečenica koja se trenutno obrađuje vezuje na linearno bliži, odnosno na hijerarhijski niži antecedent. Ova se pojava naziva i učinkom lokalnosti ili recentnosti (izv. eng. locality / recency effect).

\section{Minimal attachment - načelo minimalnoga vezanja}

Načelo minimalnoga vezanja je, uz načelo kasnoga zatvaranja, jedno od načela modularnog modela vijugavoga puta. Ono implicira da je prilikom obrade poželjna struktura koja u interpretaciji podrazumijeva manje čvorova (primjerice, vezivanje na glavne imenske i glagolske strukture), što sugerira i samo ime načela.

\section{Nonlocal/high attachment preference - nelokalna/viša preferencija vezivanja}

U kontekstu studija preferencija vezivanja, pojam kojim se označava da se u pojedinome jeziku rečenične strukture tumače na način da se fraza, tj. surečenica koja se trenutno obrađuje vezuje na linearno dalji, odnosno na hijerarhijski viši antecedent.

\section{Offline methods - metode u odgođenom vremenu}

Metode u odgođenom vremenu podrazumijevaju eksperimentalne zadatke u kojima se izvedba pojedinca ne mjeri tijekom izvršavanja zadatka, već se isključivo stječe uvid u krajnji, tj. konačni rezultat. Metode stoga ne pružaju uvid u inkrementalne procese tijekom izvedbe, odnosno u sam vremenski tijek obrade, što je i njihova najveća manjkavost. Prednost uporabe metoda u odgođenom vremenu jesu ekonomičnost i jednostavnost u primjeni i interpretaciji.

\section{Online methods - metode u stvarnom vremenu}

Metode u stvarnom vremenu podrazumijevaju eksperimentalne zadatke u kojima se izvedba pojedinca mjeri u samome trenutku izvršavanja zadatka. U kontekstu psiholingvističkih istraživanja ove metode omogućavaju izravno promatranje procesa u pozadini jezične obrade. Njima se stječe uvid u vremenski tijek obrade i mjeri se sudionikov nesvjesni odgovor na podražaj. Na ovaj način sve pozadinske strategije odmah postaju razvidne. Metodama u 
stvarnom vremenu bilježi se vrijeme reakcije, promatraju pokreti oka tijekom čitanja ili slušanja ili se ispituje moždana aktivnost tijekom izvođenja zadataka.

\section{Operation span task - zadatak raspona radnoga pamćenja pri računanju}

Zadatak raspona radnoga pamćenja pri računanju (Turner i Engle, 1989) složeni je zadatak raspona radnoga pamćenja u kojem pojedinac nastoji upamtiti niz nepovezanih riječi (ili grafema) koje se pojavljuju na kartici ili zaslonu računala, istovremeno rješavajući jednostavne matematičke zadatke. Nakon nekoliko čestica čiji se broj postupno ili nasumično povećava, osoba se pokušava dosjetiti točnoga redoslijeda prikazanih riječi ili grafema. Zadatak, jednako kao i zadatak raspona radnoga pamćenja pri čitanju (vidi reading span task), predstavlja valjanu mjeru raspona verbalnoga radnog pamćenja. U umjerenoj je do visokoj korelaciji s jezičnim razumijevanjem, a dio varijance dijeli i s testovima opće inteligencije.

\section{Parsing / syntactic processing - sintaktička obrada}

Sintaktička obrada općeniti je i krovni pojam koji podrazumijeva procese uključene u izgradnju sintaktičkih struktura tijekom razumijevanja i proizvodnje jezika koji se protežu u vremenu i međusobno nadograđuju. Neki autori sintaktičkom obradom smatraju isključivo obradu strukturne razine rečenice koja se odvija neovisno o obradi značenja, zbog čega pojam parsing strogo razdvajaju od pojma obrada značenja pod kojim podrazumijevaju naknadno oslanjanje na značenjske i pragmatičke te ostale nestrukturne čimbenike kojima govornik dolazi do konačnoga razumijevanja rečenice. Drugi pak autori zagovaraju istovremenu obradu obiju razina i stoga najčešće upotrebljavaju jedan krovni pojam, syntactic processing. Odnos tih razina, tj. točan način pristupanja (ne)strukturnim obavijestima u rečenici u trenutku obrade, $\mathrm{i}$ danas je predmetom rasprava u psiholingvističkim znanstvenim krugovima, zbog čega smo svjedocima brojnih modela sintaktičke obrade. U literaturi se tako najčešće upotrebljava pojam syntactic processing ili, ako se želi istaknuti automatska i/ili strukturna razina obrade jezika, parsing. 


\section{Processing cost - obradbeni zahtjevi, obradbeni napor, napor obrade}

Pojam koji obuhvaća zahtjevnost u obradi pojedinih struktura uslijed različitih čimbenika, poput opterećenosti sustava radnoga pamćenja, neprikladnosti ili nedovoljne prirodnosti čestica u pojedinome jeziku, njihove niske čestotnosti, negramatičnosti i slično.

\section{Reaction time measure - mjera vremena reakcije}

Mjera vremena reakcije podrazumijeva mjerenje i analizu vremena koje je osobi potrebno za izvršenje određenoga zadatka ili odgovaranje na određeni podražaj. Primjenjiva je u bilo kojoj empirijskoj studiji u kojoj se na taj način može odgovoriti na istraživačko pitanje. Promatra se brzina, tj. latencija sudionikova odgovora, a vrijeme se bilježi u milisekundama. Neke od prednosti mjerenja vremena reakcije jesu mogućnost ispitivanja različitih (psiho)lingvističkih teorijskih pristupa i jezičnih sastavnica, mogućnost osmišljavanja vlastitih zadataka ovisno o području koje se želi istražiti, mogućnost dobivanja više osjetljivijih podataka o mentalnim reprezentacijama $u$ pozadini jezičnoga znanja nego je to slučaj s drugim metodama te omogućavanje stjecanja uvida u točno vrijeme aktivacije različitih strategija obrade. Nedostatci su činjenica da je metoda manje izravna od onih koje uključuju podatke o pogreškama i točnim odgovorima, a vrijeme reakcije samo po sebi nije jezično ponašanje već je pod utjecajem brojnih drugih čimbenika koje nije jednostavno kontrolirati. Iz tih se razloga dobiveni podatci o jezičnomu znanju i obradi češće mogu primijeniti na skupinu ljudi negoli na pojedinca.

\section{Reading span task - zadatak raspona radnoga pamćenja pri čitanju}

Zadatak raspona radnoga pamćenja pri čitanju (Daneman i Carpenter, 1980) predstavlja mjeru funkcionalnoga kapaciteta radnoga pamćenja, tj. mjeru raspona verbalnoga radnog pamćenja. Za razliku od mjera kratkoročnoga pamćenja, koje zahtijevaju pasivnu pohranu i priziv određenih informacija, u ovome se zadatku od sudionika traži aktivnije sudjelovanje (jednako kao i u zadatku raspona radnoga pamćenja pri računanju; vidi operation span task). Naime, osoba u zadatku čita jednu po jednu rečenicu koje su međusobno nepovezane, istovremeno pamteći posljednje riječi u rečenicama. Nakon svakoga pročitanog niza rečenica, osoba ispravnim redoslijedom treba ponoviti posljednje riječi u svim do tada pročitanim rečenicama. Raspon radnoga pamćenja najčešće se određuje kao broj riječi kojih se osoba točno prisjeća u ispravnom redoslijedu njihova pojavljivanja. Analogna je inačica ovoga zadatka zadatak 
raspona radnoga pamćenja pri slušanju (izv. eng. listening span test; Daneman i Carpenter, 1980).

\section{Self-paced reading - čitanje vlastitom brzinom}

Čitanje vlastitom brzinom ili samostalno čitanje podrazumijeva zadatak u kojem sudionici određeni tekst prikazan na zaslonu računala čitaju riječ-po-riječ ili frazu-po-frazu. Pritom sami pritiskom tipke kontroliraju kada će se na zaslonu prikazati sljedeći podražaj. Dakle, svaki je sljedeći podražaj maskiran dok osoba ne obradi onaj koji joj je trenutačno dostupan. Glavna je pretpostavka metode da odgođeno vrijeme pritiska tipke (latencija u davanju odgovora) podrazumijeva veće teškoće jezične obrade. Prednosti su što se metoda može primijeniti na puno različitih jezičnih fenomena i što iziskuje vrlo malo opreme, zbog čega se može koristiti i izvan strogo laboratorijskih uvjeta. Glavni joj je nedostatak manjak prirodnosti u procesu čitanja i potreba za aktivnim angažmanom sudionika istraživanja, što u pitanje dovodi njegovu automatsku obradu. Metoda koja koristi paradigmu čitanja vlastitom brzinom na jednostavan način otkriva psihološke procese koji se odvijaju u pozadini dok osoba razumijeva određeni tekst te daje uvid u vremensku dimenziju procesa razumijevanja.

\section{Semantic plausibility - značenjska prihvatljivost / vjerojatnost}

Značenjska prihvatljivost (vjerojatnost) pojam je koji se može upotrijebiti u mnogim kontekstima. U jezičnoj obradi predstavlja jedan od ključeva (vidi cues) na koji se govornik oslanja prilikom tumačenja rečenica (usko vezan uz enciklopedijsko znanje), dok u zadatcima razvijenima za potrebe psiholingvističkih (bihevioralnih i eksperimentalnih) istraživanja označava prihvatljivost određenoga iskaza s obzirom na enciklopedijsko znanje. Primjerice, značenjska prihvatljivost može biti varijablom koja se kontrolira ili kojom se pak manipulira za potrebe istraživačkoga nacrta kako bi se ispitao utjecaj toga ili nekih drugih čimbenika na jezičnu obradu. Tako će rečenica Sunce je pjevalo biti značenjski potpuno neprihvatljiva, rečenica Sunce je gorjelo značenjski donekle prihvatljiva, dok će rečenica Sunce je žuto biti značenjski potpuno prihvatljiva. 


\section{Spill-over effect - učinak prelijevanja}

Pojam koji se odnosi na činjenicu da obrada određenoga podražaja ne završava nužno s prekidom njegovoj izloženosti. U kontekstu istraživanja jezične obrade metodama u stvarnom vremenu učinak prelijevanja podrazumijeva da složenost jedne riječi utječe na obradu riječi koja slijedi. Što je riječ složenija za obradu, manje vremena preostaje za obradu sljedeće, stoga kažemo da se složenost te riječi prelijeva i odražava na obradu sljedeće riječi. Primjerice, zbog učinka prelijevanja trajanje fiksacije na riječi koja slijedi nakon riječi niske čestotnosti ili sintaktički složenoga i gramatički neispravnoga dijela rečenice, može biti produljeno.

\section{Syntactic ambiguity - sintaktička dvosmislenost}

Pojam kojim se opisuje višestruka mogućnost interpretacije određene rečenice, a što izravno dovodi do dvostrukoga značenja danoga izraza. Dvosmislenost je najčešće uvjetovana dvosmislenom strukturom u kojoj ni oslanjanje na ključeve poput redoslijeda riječi, morfoloških ili prozodijskih obilježja ne može olakšati interpretaciju. Rečenica je dakle dvosmislena ako njezina strukturna obilježja, u potpunom nedostatku širega konteksta, čitatelju ili slušatelju dozvoljavaju višestruku interpretaciju. Pritom sintaktička dvosmislenost nije posljedica višestrukog značenja pojedinačnih riječi (leksička dvosmislenost), već veza između riječi, sintagmi i/ili duljih fraza u spornoj rečenici.

\section{Syntactic ambiguity resolution - razrješavanje sintaktičke dvosmislenosti}

Pojam kojim se obilježava prestanak dvosmislenosti iskaza. U eksperimentalnome kontekstu, dvosmislenost je razriješena ako dvosmislena rečenica $u$ jednome svome dijelu postaje jasna, tj. jednoznačna i nedvosmislena. To se postiže na različite načine i ovisi o čimbenicima koji se najčešće kontroliraju u istraživačkim nacrtima. Razrješavanje sintaktičke dvosmislenosti postiže se gramatičkim obilježjima (sročnošću u rodu i broju) ili značenjskim obilježjima (značenjskom prihvatljivošću i vjerojatnošću s obzirom na enciklopedijsko znanje). U neeksperimentalnome kontekstu, pojmom se označuje općeniti prestanak bilo kakve dvojbe u tumačenju iskaza. 


\section{Syntax first - prevlast strukture u obradi}

Pristupi sintaktičkoj obradi prema kojima se govornici najprije oslanjaju na strukturna obilježja, dok se značenjske obavijesti počinju obrađivati naknadno i imaju tek usputnu ulogu u obradi. Pristupi prevlasti ili dominacije strukture svojstveni su, primjerice, modularnim modelima koji sintaktičkom obradom smatraju isključivo obradu strukturne razine rečenice neovisno o obradi značenja i podrazumijevaju tek naknadno oslanjanje na značenjske i pragmatičke te ostale nestrukturne čimbenike kojima govornik dolazi do konačnoga razumijevanja rečenice (vidi i parsing).

\section{Temporary ambiguity - privremena dvosmislenost}

Za razliku od potpune dvosmislenosti, privremena dvosmislenost podrazumijeva naknadnu mogućnost dohvaćanja jedinstvene i nedvosmislene interpretacije rečenice iz razloga što je inicijalna dvojba razriješena naknadno u rečenici. Dvosmislenost se može razriješiti: a) strukturnim obilježjima poput redoslijeda riječi i sročnosti u rodu ili broju te b) značenjskim obilježjima poput enciklopedijskoga znanja. Najčešće se, upravo u istraživanjima sintaktičke obrade, pomno kontroliraju i mjesto i način razrješavanja privremene dvosmislenosti kako bi se moglo tvrditi da upravo određeni čimbenik koji se ispituje, a ne neki drugi, značajno utječe na obradu.

\section{Tuning - ugađanje}

Ugađanje (izv. eng. tuning; Mitchell i sur., 1995) pripada jednoj od pretpostavki o jezičnoj obradi prema kojoj je prethodno jezično iskustvo temeljni čimbenik koji utječe na sintaktičku obradu. Drugim riječima, odlučujući će čimbenik pri razumijevanju biti učestalost pojavnosti određenih struktura $\mathrm{u}$ pojedinome jeziku te će se govornici prilikom njihova tumačenja (posebice u slučaju dvosmislenih iskaza) voditi mogućnošću koja je izglednija s obzirom na prethodno iskustvo susretanja s tom strukturom, tj. njezinu čestotnost, $\mathrm{u}$ danome jeziku. Najčešći je i najpouzdaniji način provjere ove hipoteze psiholingvistički eksperiment potkrijepljen korpusnim podatcima. 


\section{Unrestricted race model - model neograničene utrke}

Model neograničene utrke (Van Gompel i sur., 2000) model je sintaktičke obrade koji pripada obitelji takozvanih nespecificiranih modela koji posjeduju obilježja i modularnih i interaktivnih, ali se ujedno od oba značajno razlikuju. Sličnost se s interaktivnim modelima očituje u neograničenim mogućnostima oslanjanja na različite izvore obavijesti prilikom sintaktičke obrade, dok se sličnost s modularnima očituje u postavci da govornik odmah gradi isključivo jednu interpretaciju rečenice i ne razmatra alternativne mogućnosti, unatoč njihovoj dostupnosti. Drugim riječima, prema ovome modelu gradnja se strukture i značenja oblikuje na jedan način od samog trenutka započinjanja čitanja ili slušanja rečenice. Glavno je obilježje kojim se dokazuje ovaj model iznimno kratka obrada u potpunosti dvosmislenih rečenica (primjerice, odnosnih rečenica koje dozvoljavaju višestruku interpretaciju), bez znakova teškoća u obradi, odnosno produljena obrada rečenica u kojima postoji djelomična dvosmislenost (primjerice, odnosnih rečenica u kojima postoji jasna modifikacija prve, $t \mathrm{j}$. druge imenice unutar imenske skupine).

\section{Wrap-up effect - učinak završavanja}

Pojam koji se odnosi na činjenicu da govornik prilikom obrade koje jezične strukture sadržaj u potpunosti ujedinjuje u smislenu cjelinu tek na samome kraju iskaza. Učinak završavanja tako podrazumijeva da čitatelj više vremena provodi čitajući posljednje riječi u rečenici negoli čitajući riječi u središnjem dijelu, do čega dolazi uslijed krajnje unutar-rečenične i međurečenične integracije. Važno je napomenuti da ovaj učinak nije u opreci s inkrementalnom obradom. Naime, iako se obrada odvija postupno i nadograđuje se, ipak je izgledno da će obavijest biti u potpunosti cjelovita na samome kraju rečenice ili iskaza, zbog čega se čitatelj dulje zadržava upravo na tome dijelu. 


\section{POPIS LITERATURE}

1. Abdelghany, H.; Fodor, J. D. (1999) Low attachment of relative clauses in Arabic. Poster: Architectures and Mechanisms of Language Processing (AMLaP), Edinburgh, UK.

2. Agić, Ž. (2012) Pristupi ovisnosnom parsanju hrvatskih tekstova. Doktorska disertacija. Sveučilište u Zagrebu: Filozofski fakultet.

3. Alloway, T. P. (2009) Working memory, but not IQ, predicts subsequent learning in children with learning difficulties. European Journal of Psychological Assessment, 25(2), str. 92-98.

4. Altmann, G. T. M.; Steedman, M. J. (1988) Interaction with context during human sentence processing. Cognition, 30, str. 191-238.

5. Anderson, J. R.; Lebiere, C. (1998) The atomic components of thought. Mahwah, NJ: Erlbaum.

6. Andrews III, A. D. (1985) Studies in the Syntax of Relative and Comparative Clauses. London: Routledge.

7. Auburger, L. (2015) Pregledna morfologija pravih glagolskih imenica hrvatskoga književnog jezika. Jezik: Časopis za kulturu hrvatskoga književnog jezika, 62(2-3), str. 59-75.

8. Baayen, H. (2014) Experimental and psycholinguistic approaches to studying derivation. U: Lieber, R.; Stekauer, P., ur. The Oxford Handbook of Derivation. Oxford University Press, str. 95-117.

9. Babić, S. (2002) Tvorba riječi u hrvatskome književnome jeziku. Treće, poboljšano izdanje. Zagreb: Hrvatska akademija znanosti i umjetnosti - Nakladni zavod Globus.

10. Baccino, T.; De Vincenzi, M.; Job, R. (2000) Cross-linguistic studies of the Late Closure strategy: French and Italian. U: De Vincenzi, M.; Lombardo, V., ur. Cross-Linguistic Perspectives on Language Processing. Dordrecht: Kluwer Academic, str. 89-118.

11. Baddeley, A. D. (1990) Human memory: Theory and practice. London: LEA.

12. Baddeley, A. D. (2003) Working memory and language: An overview. Journal of Communication Disorders, 36(3), str. 189-208.

13. Baddeley, A. D.; Hitch, G. J. (1974) Working memory. U: Bower, G. H., ur. The psychology of learning and motivation: Advances in research and theory, Vol. 8. New York: Academic Press, str. 47-89.

14. Balija, M.; Hržica, G.; Kuvač Kraljević, J. (2012) Odnosne rečenice bez pomaka i traga: proizvodnja odnosnih rečenica kod djece s posebnim jezičnim teškoćama. Suvremena lingvistika, 38(74), str. 139-154.

15. Balija Mećar, M.; Pavičić Dokoza, K.; Dulčić, A. (2016) Utjecaj roda i broja u razumijevanju odnosnih rečenica kod djece s posebnim jezičnim teškoćama. Logopedija, 6(1), str. 38-45. 
16. Barić, E. i sur. (2005) Hrvatska gramatika. Četvrto izdanje. Zagreb: Školska knjiga.

17. Bates, E.; McNew, S.; MacWhinney, B.; Devescovi, A.; Smith, S. (1982) Functional constraints on sentence processing: A cross-linguistic study. Cognition, 11(3), str. 245-299.

18. Betancort, M.; Carreiras, M.; Sturt, P. (2009) The processing of subject and object relative clauses in Spanish: An eye-tracking study. The Quarterly Journal of Experimental Psychology, 62(10), str. 1915-1929.

19. Brysbaert, M.; Mitchell, D. C. (1996) Modifier attachment in sentence processing: Evidence from Dutch. The Quarterly Journal of Experimental Psychology, 49A, str. 664-695.

20. Buswell, G. T. (1922) Fundamental reading habits: a study of their development. Chicago: University of Chicago Press.

21. Carreiras, M.; Betancort, M.; Meseguer, E. (2001) Relative clause attachment in Spanish: Do readers use different strategies when disambiguating by gender and number? Poster: 14th annual CUNY conference on human sentence processing, University of Pennsylvania, Philadelphia, PA.

22. Carreiras, M.; Clifton, C. (1999) Another word on parsing relative clauses: Eyetracking evidence from Spanish and English. Memory \& cognition, 27(5), str. 826-833.

23. Carreiras, M.; Clifton C. Jr. (2004) On the on-line study of language comprehension. U: Carreiras, M.; Clifton, C. Jr., ur. The on-line study of sentence comprehension: Eyetracking, ERPs and beyond. New York: Psychology Press, str. 1-14.

24. Clahsen, H. (2008) Behavioral methods for investigating morphological and syntactic processing in children. U: Sekerina, I.; Fernández, E. M.; Clahsen H., ur. Developmental psycholinguistics: online methods in children's language processing. Amsterdam: Benjamins, str. 1-27.

25. Christianson, K.; Luke, S. G. (2011) Context strengthens initial misinterpretations of text. Scientific Studies of Reading, 15(2), str. 136-166.

26. Conway, A. R. A.; Kane, M. J.; Engle, R. W. (2003) Working memory capacity and its relation to general intelligence. Trends in cognitive sciences, 7(12), str. 547-552.

27. Conway, A. R. A.; Kane, M. J.; Bunting, M. F.; Hambrick, D. Z.; Wilhelm, O.; Engle, R. W. (2005) Working memory span tasks: A methodological review and user's guide. Psychonomic Bulletin and Review, 12(5), str. 769-786.

28. Cuetos, F.; Mitchell, D. C. (1988) Cross-linguistic differences in parsing: Restrictions on the use of the Late Closure Strategy in Spanish. Cognition, 30(1), str. 73-105. 
29. Cuetos, F.; Mitchell, D. C.; Corley, M. M. B. (1996) Parsing in different languages. U: Carreiras, M.; García-Albea, J.; Sebastián-Gallés, N., ur. Language Processing in Spanish. Hillsdale, NJ: Lawrence Erlbaum, str. 145-187.

30. Daneman, M.; Carpenter, P. A. (1980) Individual differences in working memory and reading. Journal of Verbal Learning \& Verbal Behavior, 19(4), str. 450-466.

31. Daneman, M.; Carpenter, P. A. (1983) Individual differences in integrating information between and within sentences. Journal of Experimental Psychology: Learning, Memory, \& Cognition, 9(4), str. 561-584.

32. Desmet, T.; De Baecke, C.; Brysbaert, M. (2002) The influence of referential discourse context on modifer attachment in Dutch. Memory and Cognition, 30(1), str. 150-157.

33. Desmet, T.; De Baecke, C.; Drieghe, D.; Brysbaert, M.; Vonk, W. (2006) Relative clause attachment in Dutch: On-line comprehension corresponds to corpus frequencies when lexical variables are taken into account. Language and Cognitive Processes, 21(4), str. 453-485.

34. Deutsch, A.; Bentin, S. (2001) Syntactic and semantic factors in processing gender agreement in Hebrew: Evidence from ERPs and eye movements. Journal of memory and language, 45(2), str. 200-224.

35. De Vincenzi, M.; Job, R. (1993) Some observations on the universality of the late-closure strategy. Journal of Psycholinguistic Research, 22(2), str. 189-206.

36. Dussias, P. E. (2003) Syntactic ambiguity resolution in L2 learners: Some effects of bilinguality on L1 and L2 processing strategies. Studies in Second Language Acquisition, 25(4), str. 529557.

37. Dussias, P. E.; Sagarra, N. (2007) The effect of exposure on syntactic parsing in SpanishEnglish bilinguals. Bilingualism: Language and Cognition, 10(1), str. 101-116.

38. Ehrlich, K. (1999) Low attachment of relative clauses: New data from Swedish, Norwegian and Romanian. Poster: 12th annual CUNY conference on human sentence processing, City University of New York.

39. Engle, R. W. (2002) Working memory capacity as executive attention. Current Directions in Psychological Science, 11(1), str. 19-23.

40. Engle, R. W.; Cantor, J.; Carullo, J. J. (1992) Individual differences in working memory and comprehension: A test of four hypotheses. Journal of Experimental Psychology: Learning, Memory, \& Cognition, 18(5), str. 972-992.

41. Engle, R. W.; Conway, A. R. A. (1998) Working Memory and Comprehension. U: Logie, R. H.; Gilhooly, K. J., ur. Working Memory and Thinking: Current Issues In Thinking And Reasoning. London: Routledge, str. 66-90. 
42. Engle, R. W.; Kane, M. J.; Tuholski, S. W. (1999) Individual differences in working memory capacity and what they tell us about controlled attention, general fluid intelligence and functions of the prefrontal cortex. U: Miyake, A.; Shah, P., ur. Models of working memory: Mechanisms of active maintenance and executive control. London: Cambridge University Press, str. 102134.

43. Erteschik-Shir, N. (2009) Information structure: The syntax-Discourse Interface. New York: Oxford University Press.

44. Eysenck, M. W.; Keane, M. T. (2015) Cognitive psychology: A student's handbook. Sedmo izdanje. New York: Psychology Press.

45. Felser, C.; Marinis, T.; Clahsen, H. (2003) Children's processing of ambiguous sentences: A study of relative clause attachment. Language Acquisition, 11(3), str. 127-163.

46. Fernández, E. M. (2003) Bilingual sentence processing: relative clause attachment in English and Spanish [Language Acquisition and Language Disorders, Vol. 29]. USA: John Benjamins Publishing.

47. Fernández, E. M.; Sainz, J. (2004) Early preferences in RC attachment in Spanish: Two methods, and disambiguation by number agreement. Poster: Architecture and Mechanisms of Language Processing (AMLaP), Aix-en-Provence, Francuska. URL: http://citeseerx.ist.psu.edu/viewdoc/download;jsessionid=602C5391C7342AC7088A1344B85 BA51A?doi=10.1.1.538.1396\&rep=rep1\&type=pdf (pristupljeno 26. kolovoza 2018).

48. Fodor, J. A. (1983) The Modularity of Mind. Cambridge, MA: MIT Press.

49. Fodor, J. D. (1998) Learning to parse? Journal of Psycholinguistic Research, 27(2), str. 285319.

50. Fodor, J. D. (2002) Psycholinguistics cannot escape prosody. U: International Speech Communication Association. Speech Prosody 2002, International Conference in Aix-enProvence, France, str. 83-90. URL: $\underline{\text { https://www.isca- }}$ speech.org/archive/sp2002/papers/sp02_083.pdf (pristupljeno 19. srpnja 2018).

51. Forster, K. I. (2000) The potential for experimenter bias effects in word recognition experiments. Memory \& Cognition, 28(7), str. 1109-1115.

52. Foster, J. L.; Shipstead, Z.; Harrison, T. L.; Hicks, K. L.; Redick, T. S.; Engle, R. W. (2015) Shortened complex span tasks can reliably measure working memory capacity. Memory \& cognition, 43(2), str. 226-236.

53. Frazier, L. (1979) On comprehending sentences: syntactic parsing strategies. Doktorska disertacija. Sveučilište u Connecticutu. 
54. Frazier, L. (1987) Sentence processing: A tutorial review. U: Coltheart, M., ur. Attention and performance 12: The psychology of reading. Hillsdale, NJ, SAD: Lawrence Erlbaum Associates, Inc., str. 559-586.

55. Frazier, L. (1990) Parsing modifiers: Special purpose routines in the human sentence processing mechanism? U: Balota, D. A.; d'Arcais, Flores G. B.; Rayner, K., ur. Comprehension Processes in Reading. Hillsdale NJ: Lawrence Erlbaum, str. 303-330.

56. Frazier, L.; Carlson, K.; Clifton Jr., C. (2006) Prosodic phrasing is central to language comprehension. Trends in cognitive sciences, 10(6), str. 244-249.

57. Frazier, L.; Clifton, C. (1996) Construal. MIT Press.

58. Frazier, L.; Clifton, C. (1997) Construal: Overview, motivation, and some new evidence. Journal of Psycholinguistic Research, 26(3), str. 277-295.

59. Frazier, L.; Clifton, C. Jr. (1998) Comprehension of sluiced sentences. Language and Cognitive Processes, 13(4), str. 499-520.

60. Frazier, L.; Fodor, J. D. (1978) The sausage machine: a new two stage parsing model. Cognition, 6(4), str. 291-326.

61. Frazier, L.; Rayner, K. (1982) Making and correcting errors during sentence comprehension: Eye movements in the analysis of structurally ambiguous sentences. Cognitive Psychology, 14(2), str. 178-210.

62. Frenck-Mestre, C.; Pynte, J. (2000) Resolving syntactic ambiguities: Cross-linguistic differences? U: De Vincenzi M.; Lombardo V., ur. Cross-Linguistic Perspectives on Language Processing. Dordrecht: Kluwer Academic, str. 119-148.

63. Friederici, A. D.; Steinhauer, K.; Mecklinger, A.; Meyer, M. (1998) Working memory constraints on syntactic ambiguity resolution as revealed by electrical brain responses. Biological psychology, 47(3), str. 193-221.

64. Friedmann, N.; Novogrodsky, R. (2004) The acquisition of relative clause comprehension in Hebrew: A study of SLI and normal development. Journal of Child Language, 31(3), str. 661681.

65. Gathercole, S. E.; Alloway, T. P.; Willis, C.; Adams, A. M. (2006) Working memory in children with reading disabilities. Journal of experimental child psychology, 93(3), str. 265-281.

66. George, D.; Mallery, M. (2010) SPSS for Windows Step by Step: A Simple Guide and Reference, 17.0 update. Deseto izdanje. Boston: Pearson.

67. Gibson, E. (1998) Linguistic complexity: locality of syntactic dependencies. Cognition, 68(1), str. 1-76. 
68. Gibson, E.; Schütze, C. (1999) Disambiguation preferences in noun phrase conjunction do not mirror corpus frequency. Journal of Memory and Language, 40(2), str. 263-279.

69. Gilboy, E.; Sopena, J. M.; Clifton Jr., C.; Frazier, L. (1995) Argument structure and association preferences in Spanish and English complex NPs. Cognition, 54(2), str. 131-167.

70. Green, M. J.; Mitchell, D. C. (2006) Absence of real evidence against competition during syntactic ambiguity resolution. Journal of Memory and Language, 55(1), str. 1-17.

71. Grosz, B. J.; Joshi, A. K.; Weinstein, S. (1995) Centering: A framework for modeling the local coherence of discourse. Computational Linguistics, 21(2), str. 203-225.

72. Hagège, C. (2010) Adpositions: Oxford studies in typology and linguistic theory. Oxford University Press.

73. Håkansson, G.; Hansson, K. (2000) Comprehension and production of relative clauses: A comparison between Swedish impaired and unimpaired children. Journal of Child Language, 27(2), str. 313-333.

74. Heine, B. (1997) Possession - Cognitive Sources, Forces and Grammaticalization. Cambridge: Cambridge University Press.

75. Hemforth, B.; Fernandez, S.; Clifton Jr., C.; Frazier, L.; Konieczny, L.; Walter, M. (2015) Relative clause attachment in German, English, Spanish and French: effects of position and length. Lingua, 166, str. 43-64.

76. Hemforth, B.; Konieczny, L.; Scheepers, C.; Strube, G. (1998) Syntactic ambiguity resolution in German. U: Hillert, D., ur. Syntax and semantics (Vol 31): Sentence processing: A crosslinguistic perspective. London: Academic Press, str. 293-312.

77. Hemforth, B.; Konieczny, L.; Scheepers, C. (2000a) Modifier attachment: Relative clauses and coordinations. U: Hemforth, B.; Konieczny, L., ur. German sentence processing. Springer Science and Business Media, str. 161-186.

78. Hemforth, B.; Konieczny, L.; Scheepers, C. (2000b) Syntactic attachment and anaphor resolution: Two sides of relative clause attachment. U: Crocker, M.; Pickering, M. J.; Clifton, C., ur. Architectures and mechanisms for language processing. Cambridge: Cambridge University Press, str. 259-282.

79. Hernández, A. E.; Bates, E. A.; Avila, L. X. (1994) On-line sentence interpretation in SpanishEnglish bilinguals: What does it mean to be "in between"? Applied Psycholinguistics, 15(4), str. 417-446.

80. Hill, R. L.; Murray, W. S. (2000) Comma and spaces: Effects of punctuation on eye movements and sentence parsing. U: Kennedy, A.; Radach, R.; Heller, D.; Pynte, J., ur. Reading as a perceptual process. Oxford: Elsevier, str. 565-590. 
81. Holmqvist, K.; Nyström, M.; Andersson, R.; Dewhurst, R.; Jarodzka, H.; Van de Weijer, J. (2011) Eye tracking: A comprehensive guide to methods and measures. OUP Oxford.

82. Jegerski, J. (2014) Self-paced reading. U: Jegerski, J.; Van Patten, B., ur. Research methods in second language psycholinguistics. New York: Routledge, str. 20-49.

83. Just, M. A.; Carpenter, P. A. (1980) A theory of reading: from eye fixations to comprehension. Psychological Review, 87(4), str. 329-354.

84. Just, M. A.; Carpenter, P. A. (1992) A capacity theory of comprehension: Individual differences in working memory. Psychological Review, 99(1), str. 122-149.

85. Just, M. A.; Carpenter, P. A.; Woolley, J. D. (1982) Paradigms and processes in reading comprehension. Journal of Experimental Psychology: General, 111(2), str. 228-238.

86. Kamide, Y.; Mitchell, D. C. (1997) Relative clause attachment: Nondeterminism in Japanese parsing. Journal of Psycholinguistic Research, 26(2), str. 247-254.

87. Katičić, R. (1994) Nešto napomena o vezi između atributnih korelativa i 'restriktivnosti' odnosnih rečenica u hrvatskome književnom jeziku. Jezik, 41(3), str. 65-77.

88. Katičić, R. (2002) Sintaksa hrvatskoga književnog jezika. Treće, poboljšano izdanje. Zagreb: HAZU, Nakladni Zavod Globus.

89. Katunar, D. (2015) Ustroj leksikona u konstrukcijskoj gramatici - primjer prijedloga u hrvatskom jeziku. Doktorska disertacija. Sveučilište u Zagrebu: Filozofski fakultet.

90. Kaya, M. (2012) Working memory and relative clause attachment preferences in Turkish: an eye-tracking study. Studia Uralo-Altaica, 49, str. 265-278.

91. Kemper, S.; Crow, A.; Kemtes, K. (2004) Eye-fixation patterns of high- and low-span young and older adults: Down the garden path and back again. Psychology and Aging, 19(1), str. 157170.

92. Kordić, S. (1995) Relativna rečenica. Zagreb: Matica hrvatska.

93. Krifka, M.; Musan, R. (2012) Information structure: Overview and linguistic issues. U: Krifka, M.; Musan, R., ur. The expression of information structure. Berlin/Boston: De Gruyter Mouton, str. 1-45.

94. Kuna, B. (1999) Norma i posvojni genitiv bez odredbe. Jezik, 47(1), str. 1-9.

95. Kuna, B. (2002) Atributni genitiv u hrvatskome standardnom jeziku. Doktorska disertacija. Sveučilište u Zagrebu: Filozofski fakultet.

96. Kuna, B. (2003) NP-pomicanje i posvojni genitiv. Jezikoslovlje, 4(2), str. 245-261.

97. Kuna, B. (2012) Predikatna i vanjska posvojnost u hrvatskome jeziku. Osijek: Filozofski fakultet J. J. Strossmayera u Osijeku. 
98. Kuperman, V. (2015) Virtual experiments in megastudies: a case study of language and emotion. The Quarterly Journal of Experimental Psychology, 68(8), str. 1693-1710.

99. Kurzová, H. (1981) Der Relativsatz in den indoeuropäischen Sprachen. Hamburg: Helmut Buske.

100. Kuvač, J.; Palmović, M. (2007) Metodologija istraživanja dječjega jezika. Jastrebarsko: Naklada Slap.

101. Kuvač Kraljević, J. (2008) Kompeticijski model jezičnoga usvajanja na primjeru jezične obrade u hrvatskome (u djece urednoga jezičnoga razvoja $i$ djece s posebnim jezičnim teškoćama (PJT)). Doktorska disertacija. Sveučilište u Zagrebu: Filozofski fakultet.

102. Lambrecht, K. (1994) Information Structure and Sentence Form: Topic, Focus, and the Mental Representation of Discourse Referents. Cambridge: Cambridge University Press.

103. Liversedge, S. P.; Paterson, K. B.; Pickering, M. J. (1998) Eye movements and measures of reading time. U: Underwood, G., ur. Eye guidance in reading and scene perception. Oxford: Elsevier, str. 55-75.

104. Ljubešić, N.; Klubička, F. (2016) Croatian web corpus hrWaC 2.1. Slovenian language resource repository CLARIN.SI. URL: http://nlp.ffzg.hr/resources/corpora/hrwac/ (pristupljeno 15. siječnja 2018).

105. Logačev, P.; Vasishth, S. (2016) A Multiple-Channel Model of Task-Dependent Ambiguity Resolution in Sentence Comprehension. Cognitive Science, 40(2), str. 266-298.

106. Love, T. A.; Swinney, D. A. (1998) The influence of canonical word order on structural processing. U: Hillert, D., ur. Syntax and semantics (Vol 31): Sentence processing: A crosslinguistic perspective. London: Academic Press, str. 153-166.

107. Lovrić, N. (2003) Implicit prosody in silent reading: Relative clause attachment in Croatian. Doktorska disertacija. New York: CUNY Graduate Center.

108. Lovrić, N.; Bradley, D.; Fodor, J. D. (2000) RC attachment in Croatian with and without preposition. Poster: Architectures and Mechanisms of Language Processing (AMLaP), Leiden, Nizozemska.

109. Lovrić, N.; Bradley, D.; Fodor, J. D. (2001) Silent prosody resolves syntactic ambiguities: Evidence from Croatian. 2nd SUNY / CUNY / NYU Mini-conference on Linguistics processing, City University of New York: Stony Brook.

110. Lovrić, N.; Fodor, J. D. (2000) Relative clause attachment in sentence parsing. Poster: 13th annual CUNY conference on human sentence processing, City University of New York. 
111. Lu, Y. (2015) Working Memory, Cognitive Resources and L2 Writing Performance. U: Wen, Z. E.; Borges Mota, M.; McNeill, A., ur. Working Memory in Second Language Acquisition and Processing. UK: Multilingual Matters, str. 175-189.

112. MacDonald, M. C.; Christiansen, M. C. (2002) Reassessing working memory: Comment on Just and Carpenter (1992) and Waters and Caplan (1996). Psychological Review, 109, str. 35-54.

113. MacDonald, M. C.; Just, M. A.; Carpenter, P. A. (1992) Working memory constraints on the processing of syntactic ambiguity. Cognitive psychology, 24(1), str. 56-98.

114. MacDonald, M. C.; Pearlmutter, N. J.; Seidenberg, M. S. (1994) The lexical nature of syntactic ambiguity resolution. Psychological review, 101(4), str. 676-703.

115. Maček, D. (1970) Relative pronouns in English and Serbo-Croatian. The Yugoslav Serbo-Croatian-English Contrastive Project, 3, str. 109-131.

116. Majcenović, M. (2016) Izricanje posvojnosti u hrvatskih imenica IV. $i$ V. vrste. Diplomski rad. Sveučilište u Zagrebu: Filozofski fakultet.

117. Mak, W. M.; Vonk, W.; Schriefers, H. (2006) Animacy in processing relative clauses: The hikers that rocks crush. Journal of Memory and Language, 54(4), str. 466-490.

118. Marinis, T. (2010) Using on-line processing methods in language acquisition research.

U: Unsworth, S.; Blom, E., ur. Experimental methods in language acquisition research. Amsterdam: John Benjamins (Language Learning and Language Teaching), str. 139-162.

119. Marković, I. (2008) Hrvatski posvojni pridjev kao antecedent relativnoj zamjenici. Rasprave: Časopis Instituta za hrvatski jezik i jezikoslovlje, 34(1), str. 239-253.

120. Matasović, R. (2000) The Possessive and Adjective Phrases in Croatian. Suvremena lingvistika, 49-50, str. 99-109.

121. Matasović, R. (2002) Otuđiva i neotuđiva posvojnost u hrvatskome jeziku. Rasprave: Časopis Instituta za hrvatski jezik i jezikoslovlje, 28(1), str. 151-160.

122. Matić, A. (2017) Obilježja pokreta očiju i modeli čitanja utemeljeni na uporabi uređaja za praćenje pokreta očiju. Hrvatska revija za rehabilitacijska istraživanja, 53(2), str. 130-141. 123. Matić, A. (2018) The influence of structural-semantic factors on parsing strategies and attachment preferences in Croatian. Knjiga sažetaka: 6th Young Linguists' Meeting in Poznań: From exploration to explanation in the study of language, 23.-25. studeni 2018. Cambridge University Press, str. 62-63.

124. Matić, A.; Coumel, M.; Palmović, M. (2018) Lexical processing of children with dyslexia: An eye-tracking adaptation of the Reicher-Wheeler task. Speech: Journal of Phonetics, 35(1), str. 27-52. 
125. Matić, A.; Kuvač Kraljević, J. (2017) Razumijevanje sintaktičkih struktura u odrasloj dobi - podatci s TROG-2:HR testa. Logopedija, 7(2), str. 42-48.

126. Matić, A.; Palmović, M. (2018) Foster operation span task: Croatian version. URL: http://englelab.gatech.edu/translatedtasks.html\#croatian (pristupljeno 29. kolovoza 2019).

127. Matić, A.; Willer-Gold, J.; Palmović, M.; Peti-Stantić, A. (2019) Vezanje relativne rečenice na koordiniranu skupinu u hrvatskome: psiholingvistički pogled. Rasprave: Časopis instituta za hrvatski jezik i jezikoslovlje, 45(2).

128. Matovac, D. (2013) Semantika hrvatskih prijedloga. Doktorska disertacija. Sveučilište u Osijeku: Filozofski fakultet J. J. Strossmayera.

129. McRae, K.; Spivey-Knowlton, M.; Tanenhaus, M. (1998) Modelling the effects of thematic fit (and other constraints) in on-line sentence comprehension. Journal of Memory and Language, 38(3), str. 283-312.

130. Mendelsohn, A.; Pearlmutter, N. J. (1999) Individual differences in relative clause attachment ambiguities. Poster: 12th annual CUNY conference on human sentence processing, City University of New York.

131. Mertins, B. (2016) The use of experimental methods in linguistic research: Advantages, problems and possible pitfalls. U: Anstatt, T.; Gattnar, A.; Clasmeier, C., ur. Slavic Languages in Psycholinguistics: Chances and Challenges for Empirical and Experimental Research. Tübingen: Narr Francke Attempto Verlag, str. 15-33.

132. Mimica, I. (1988) The influence of word order and case inflection on sentence comprehension at preschool children. Radovi Filozofskoga fakulteta u Zadru-Razdio filozofije, psihologije, sociologije i pedagogije, 24(4), str. 159-169.

133. Mimica, I.; Sullivan, M.; Smith, S. (1994) An on-line study of sentence interpretation in native Croatian speakers. Applied Psycholinguistics, 15(2), str. 237-261.

134. Mitchell, D. C.; Brysbaert, M. (1998) Challenges to recent theories of crosslinguistic variation in parsing: Evidence from Dutch. U: Hillert, D., ur. Syntax and semantics (Vol 31): Sentence processing: A crosslinguistic perspective. London: Academic Press, str. 313-335.

135. Mitchell, D. C.; Brysbaert, M.; Grondelaers, S.; Swanepoel, P. (2000) Modifier Attachment in DutchDutch: Testing Aspects of Construal Theory. U: Kennedy, A.; Radach, R.; Heller, D.; Pynte, J., ur. Reading as a perceptual process. Oxford: Elsevier, str. 493-516.

136. Mitchell, D. C.; Cuetos, F.; Corley, M. M.; Brysbaert, M. (1995) Exposure-based models of human parsing: Evidence for the use of coarse-grained (nonlexical) statistical records. Journal of Psycholinguistic Research, 24(6), str. 469-488. 
137. Miyake, A.; Friedman, N. P.; Emerson, M. J.; Witzki, A. H.; Howerter, A.; Wager, T.

D. (2000) The unity and diversity of executive functions and their contributions to complex "frontal lobe" tasks: A latent variable analysis. Cognitive Psychology, 41(1), str. 49-100.

138. Miyamoto, E. T. (1998) Relative clause processing in Brazilian Portuguese and Japanese. Doktorska disertacija. Massachusetts Institute of Technology.

139. Mohamed, M. T.; Clifton Jr., C. (2011) Processing temporary syntactic ambiguity: The effect of contextual bias. The Quarterly Journal of Experimental Psychology, 64(9), str. 17971820.

140. Morrison, C. M.; Ellis, A. W. (1995) Roles of word frequency and age of acquisition in word naming and lexical decision. Journal of Experimental Psychology: Learning, Memory, and Cognition, 21(1), str. 116-133.

141. Nicenboim, B.; Logačev, P.; Gattei, C.; Vasishth, S. (2016) When High-Capacity Readers Slow Down and Low-Capacity Readers Speed Up: Working Memory and Locality Effects. Frontiers in Psychology, 7(280), str. 1-24. doi: 10.3389/fpsyg.2016.00280.

142. Oberauer, K.; Süss, H. M.; Schulze, R.; Wilhelm, O.; Wittmann, W. W. (2000) Working memory capacity - facets of a cognitive ability construct. Personality and Individual Differences, 29(6), str. 1017-1045.

143. Omaki, A. (2005) Working memory and relative clause attachment in first and second language processing. Doktorska disertacija. University of Hawaii.

144. Palmović, M.; Matić, A.; Zelenika Zeba, M.; Kovačević, M. (u tisku) Phonological and lexical effects on reading in dyslexia. U: Cappelli, G.; Noccetti, S., ur. A Linguistic Approach to the Study of Dyslexia. UK: Multilingual Matters.

145. Papadopoulou, D. (2006) Cross-linguistic variation in sentence processing: Evidence from RC attachment preferences in Greek (Vol 36). Dordrecht: Springer Science \& Business Media.

146. Papadopoulou, D.; Clahsen, H. (2003) Parsing strategies in L1 and L2 sentence processing: A study of relative clause attachment in Greek. Studies in Second Language Acquisition, 25(4), str. 501-528.

147. Payne, B. R.; Grison, S.; Gao, X.; Christianson, K.; Morrow, D. G.; Stine-Morrow, E. A. (2014) Aging and individual differences in binding during sentence understanding: Evidence from temporary and global syntactic attachment ambiguities. Cognition, 130(2), str. 157-173.

148. Peti-Stantić, A. (2007) O kakvu je redu riječ?. Filologija, 46-47, str. 227-238.

149. Petz, B. (2012) Osnovne statističke metode za nematematičare. Jastrebarsko: Naklada Slap. 
150. Pickering, M. J.; Traxler, M. J.; Crocker, M. W. (2000) Ambiguity resolution in sentence processing: Evidence against frequency-based accounts. Journal of memory and language, 43(3), str. 447-475.

151. Pollatsek, A.; Reichle, E. D.; Rayner, K. (2006) Tests of the EZ Reader model: exploring the interface between cognition and eye-movement control. Cognitive Psychology, 52(1), str. $1-56$.

152. Poulsen, M. (2005) Sentence Processing and Grammaticality in Functional Linguistics: Extraction in Danish as an Example. Doktorska disertacija. Sveučilište u Kopenhagenu.

153. Pranjković, I. (1992) Prostorna značenja prijedloga u hrvatskome standardnom jeziku. Suvremena lingvistika, 33, str. 21-26.

154. Pranjković, I. (2002) Hrvatska skladnja: Rasprave iz sintakse hrvatskoga standardnog jezika. Drugo, izmijenjeno izdanje. Zagreb: Hrvatska sveučilišna naklada.

155. Pranjković, I. (2009) Prostorna značenja u hrvatskome jeziku. U: Mićanović, K., ur. Prostor u jeziku/Književnost $i$ kultura šezdesetih, Zbornik radova 37. seminara Zagrebačke slavističke škole. Zagreb: Filozofski fakultet, Zagrebačka slavistička škola, str. 11-19.

156. Pynte, J.; Colonna, S. (2000) Decoupling syntactic parsing from visual inspection: The case of relative clause attachment in French. U: Kennedy, A.; Radach, R.; Heller, D.; Pynte, J., ur. Reading as a perceptual process. Oxford: Elsevier, str. 529-547.

157. Quinn, D.; Abdelghany, H.; Fodor, J. D. (2000) More evidence of implicit prosody in reading: French and Arabic relative clauses. Poster: 13th annual CUNY conference on human sentence processing, La Jolla, California.

158. Raffaelli, I. (2015) O značenju - uvod u semantiku. Zagreb: Matica hrvatska.

159. Raguž, D. (1994) Odnosne rečenice s veznikom/relativom što. Zagreb: Hrvatska sveučilišna naklada.

160. Rayner, K. (1998) Eye movements in reading and information processing: 20 years of research. Psychological bulletin, 124(3), str. 372-422.

161. Rayner, K. (2009) Eye movements in reading: models and data. Journal of Eye Movement Research, 2(5), str. 1-10.

162. Rayner, K.; Duffy, S. A. (1986) Lexical complexity and fixation times in reading: Effects of word frequency, verb complexity, and lexical ambiguity. Memory \& cognition, 14(3), str. 191-201.

163. Rayner, K.; Pollatsek, A. (1989) The psychology of reading. Englewood Cliffs, New York: Prentice Hall. 
164. Rayner, K.; Pollatsek, A.; Ashby, J.; Clifton, C. (2012) The psychology of reading. New York, NY: Psychology Press.

165. Reich, I. (2012) Information structure and theoretical models of grammar. U: Krifka, M.; Musan, R., ur. The expression of information structure. Berlin/Boston: De Gruyter Mouton, str. 409-449.

166. Reichle, E. D.; Pollatsek, A.; Fisher, D. L.; Rayner, K. (1998) Toward a model of eye movement control in reading. Psychological Review, 105(1), str. 125-157.

167. Schafer, A. J.; Carlson, K.; Clifton, C.; Frazier, L. (2000) Focus and interpretation of pitch accents: Disambiguiting embedded questions. Language and Speech, 43(1), str. 75-105.

168. Schmitt, C.; Miller, K. (2010) Using comprehension methods in language acquisition research. U: Unsworth, S.; Blom, E., ur. Experimental methods in language acquisition research. Amsterdam: John Benjamins (Language Learning and Language Teaching), str. 3557.

169. Schroyens, W.; Vitu, F.; Brysbaert, M.; D'Ydewalle, G. (1999) Eye movement control during reading: foveal load and parafoveal processing. The Quarterly Journal of Experimental Psychology: Section A, 52(4), str. 1021-1046.

170. Sedivy, J. C. (2010) Using eyetracking in language acquisition research. U: Unsworth, S.; Blom, E., ur. Experimental methods in language acquisition research. Amsterdam: John Benjamins (Language Learning and Language Teaching), str. 115-139.

171. Sekerina, I. A.; Fernández E. M.; Clahsen, H. (2008) Introduction. U: Sekerina, I.; Fernández, E. M.; Clahsen H., ur. Developmental psycholinguistics: online methods in children's language processing. Amsterdam: Benjamins, str. 7-15.

172. Silić, J.; Pranjković, I. (2005) Gramatika hrvatskoga jezika: za gimnazije i visoka učilišta [sintaksa, morfologija, fonologija]. Zagreb: Školska knjiga.

173. Skopeteas, S. (2012) The empirical investigation of information structure. U: Krifka, M.; Musan, R., ur. The expression of information structure. Berlin/Boston: De Gruyter Mouton, str. 217-249.

174. Snedeker, J.; Trueswell, J. C. (2004) The developing constraints on parsing decisions: The role of lexical-biases and referential scenes in child and adult sentence processing. Cognitive psychology, 49(3), str. 238-299.

175. Spivey, M. J.; Tanenhaus, M. K. (1998) Syntactic ambiguity resolution in discourse: Modelling the effects of referential context and lexical frequency. Journal of Experimental Psychology: Learning, Memory, and Cognition, 24, str. 1521-1543. 
176. Staub, A. (2007) The parser doesn't ignore intransitivity, after all. Journal of Experimental Psychology: Learning, Memory, and Cognition, 33(3), str. 550-569.

177. Swets, B.; Desmet, T.; Clifton, C.; Ferreira, F. (2008) Underspecification of syntactic ambiguities: Evidence from self-paced reading. Memory \& Cognition, 36(1), str. 201-216.

178. Swets, B.; Desmet, T.; Hambrick, D. Z.; Ferreira, F. (2007) The role of working memory in syntactic ambiguity resolution: A psychometric approach. Journal of Experimental Psychology: General, 136(1), str. 64-81.

179. Šarić, L. (2006) A preliminary semantic analysis of the Croatian preposition $u$ and its Slavic equivalents. Jezikoslovlje, 7(1-2), str. 1-43.

180. Šarić, L. (2008) Spatial concepts in Slavic: a cognitive linguistic study of prepositions and cases (Vol. 19). Wiesbaden: Otto Harrassowitz Verlag.

181. Štrkalj Despot, K. (2018) Relativna rečenica u hrvatskom jeziku 15./16. stoljeća. Croatica: časopis za hrvatski jezik, književnost i kulturu, 42(62), str. 157-178.

182. Tesnière, L. (1988) Éléments de syntaxe structural. Paris: Klincksieck (1. izdanje 1959).

183. Težak, S.; Babić, S. (2005) Gramatika hrvatskoga jezika: priručnik za osnovno jezično obrazovanje. Petnaesto izdanje. Zagreb: Školska knjiga.

184. Thornton, R.; Gil, M.; MacDonald, M. C. (1998) Accounting for crosslinguistic variation: a constraint-based perspective. U: Hillert, D., ur. Syntax and semantics (Vol 31): Sentence processing: A crosslinguistic perspective. London: Academic Press, str. 211-225.

185. Thornton, R.; MacDonald, M. C.; Gil, M. (1999) Pragmatic constraints on the interpretation of complex noun phrases in Spanish and English. Journal of Experimental Psychology: Learning, Memory, and Cognition, 25(6), str. 1347-1365.

186. Traxler, M. J. (2007) Working memory contributions to relative clause attachment processing: A hierarchical linear modeling analysis. Memory \& Cognition, 35(5), str. 11071121.

187. Traxler, M. J.; Pickering, M. J.; Clifton Jr., C. (1998) Adjunct attachment is not a form of lexical ambiguity resolution. Journal of Memory and Language, 39(4), str. 558-592.

188. Traxler, M. J.; Williams, R. S.; Blozis, S. A.; Morris, R. K. (2005) Working memory, animacy, and verb class in the processing of relative clauses. Journal of Memory and Language, 53(2), str. 204-224.

189. Turner, M. L.; Engle, R. W. (1989) Is working memory capacity task dependent? Journal of Memory \& Language, 28(2), str. 127-154. 
190. Unsworth, N.; Engle, R. W. (2007) On the division of short-term and working memory: An examination of simple and complex span and their relation to higher order abilities. Psychological Bulletin, 133(6), str. 1038-1066.

191. Unsworth, N.; Heitz, R. P.; Schrock, J. C.; Engle, R. W. (2005) An automated version of the operation span task. Behavior research methods, 37(3), str. 498-505.

192. van den Noort, M.; Bosch, P.; Haverkort, M.; Hugdahl, K. (2008) A standard computerized version of the reading span test in different languages. European Journal of Psychological Assessment, 24(1), str. 35-42.

193. Van Gompel, R. P. G.; Pickering, M. J. (2007) Syntactic parsing. U: Gaskell, M. G.; Altmann, G., ur. The Oxford handbook of psycholinguistics. SAD: Oxford University Press, str. 289-307.

194. Van Gompel, R. P. G.; Pickering, M. J.; Pearson, J.; Liversedge, S. P. (2005) Evidence against competition during syntactic ambiguity resolution. Journal of Memory and Language, 52(2), str. 284-307.

195. Van Gompel, R. P. G.; Pickering, M. J.; Traxler, M. J. (2000) Unrestricted race: A new model of syntactic ambiguity resolution. U: Kennedy, A.; Radach, R.; Heller, D.; Pynte, J., ur. Reading as a perceptual process. Oxford: Elsevier, str. 621-648.

196. Van Gompel, R. P. G.; Pickering, M. J.; Traxler, M. J. (2001) Reanalysis in Sentence Processing: Evidence against Current Constraint-Based and Two-Stage Models. Journal of Memory and Language, 45(2), str. 225-258.

197. Van Valin, Jr., R. D. (2001) An Introduction to Syntax. Cambridge, UK: Cambridge University Press.

198. Van Valin, Jr., R. D. (2019) Discourse-pragmatic and other prominence factors in argument realization. Predavanje na Odsjeku za lingvistiku Filozofskog fakulteta Sveučilišta u Zagrebu, 31. svibnja 2019.

199. Vasishth, S. (2017) Introduction to Sentence Comprehension (Lectures 1-3). Predavanja u sklopu Ljetne škole lingvistike. Summer School of Linguistics, Litomyšl, Češka Republika: 20.-26. $\quad 2017 . \quad$ URL: http://www.ling.unipotsdam.de/ vasishth/courses/SummerSchoolLitomys12017.html (pristupljeno 15. srpnja 2018).

200. Vasishth, S.; Lewis, R. L. (2006) Argument-head distance and processing complexity: Explaining both locality and antilocality effects. Language, 82(4), str. 767-794.

201. Vosse, T.; Kempen, G. (2009) In defense of competition during syntactic ambiguity resolution. Journal of psycholinguistic research, 38(1), str. 1-9. 
202. Willer-Gold, J.; Arsenijević, B.; Batinić, M.; Čordalija, N.; Kresić, M.; Leko, N.; ... , Nevins, A. (2016) Conjunct Agreement and Gender in South Slavic: From Theory to Experiments to Theory. Journal of Slavic Linguistics, 24(1), str. 187-224.

203. Wind Cowles, H. (2012) The psychology of information structure. U: Krifka, M.; Musan, R., ur. The expression of information structure. Berlin/Boston: De Gruyter Mouton, str. 287-319.

204. Wingfield, A.; McCoy, S. L.; Peelle, J. E.; Tun, P. A.; Cox, C. L. (2006) Effects of adult aging and hearing loss on comprehension of rapid speech varying in syntactic complexity. Journal of the American Academy of Audiology, 17(7), str. 487-497.

205. Zagar, D.; Pynte, J.; Rativeau, S. (1997) Evidence for early closure attachment on firstpass reading times in French. Quarterly Journal of Experimental Psychology, 50A, str. 421438. 


\section{PRILOZI}

\subsection{Ispitni podražaji}

\section{1) Ispitivanja u odgođenom vremenu - upitnik prosudbe}

Kći poznate glumice koja ima srčanu manu glavna je tema u dvorani.

Tko ima srčanu manu?

Kći

Glumica

Sin bogatog trenera koji ima tešku bolest glavna je tema svake kave.

Tko ima tešku bolest?

Trener

Sin

Prijateljica naše šefice koja jako voli slavlja često uveseljava sve goste.

Tko jako voli slavlja?

Prijateljica

Šefica

Vozač našeg voditelja koji mrzi svoj posao opet je uzrokom brojnih svađa.

Tko mrzi svoj posao?

Voditelj

Vozač

Dionica utrke koja je jako naporna iscrpljuje sve sudionike natjecanja.

Što je jako naporno?

Dionica

Utrka

Krov vrtića koji je posve zapušten živcira baš sve tamošnje zaposlenike.

Što je posve zapušteno?
Vrtić
Krov

Tvornica čokolade koja je proslavila zemlju trenutno je na svim vijestima.

Što je proslavilo zemlju?

Tvornica

Čokolada

Restoran hotela koji je lijepo uređen svojim izgledom iznenađuje goste.

Što je lijepo uređeno? 
Naslovnica knjige koja je jako zanimljiva privlači sve ljude u prostoriji.

Što je jako zanimljivo?

Naslovnica

Knjiga

Naslov članka koji je pun neistina postaje predmetom vrućih rasprava.

Što je puno neistina?

Članak

Naslov

Prozor na krovu koji se počeo tresti važna je tema među stanarima.

Što se počelo tresti?

Krov

Prozor

Kuća na rijeci koja je omeđena trnjem zastrašuje svu djecu u selu.

Što je omeđeno trnjem?

\section{Kuća}

Rijeka

Hotel na trgu koji je prepun stranaca postaje atrakcija širom Europe.

Što je prepuno stranaca?

$\operatorname{Trg}$

Hotel

Slika u sobi koja je prepuna prašine danas se treba detaljno očistiti.

Što je prepuno prašine?

Slika

Soba

Prizor u filmu koji je prilično tužan oduševljava sve ljude u publici.

Što je prilično tužno?

Film

Prizor

Staza u šumi koja je prepuna stakla česta je tema među seljanima.

Što je prepuno stakla?

Staza

Šuma

Krema na torti koja se posve stvrdnula uzrokuje bijes u kuhinji hotela. 
Što se posve stvrdnulo?

Torta

Krema

Tanjur na stolu koji je pun mrvica uvijek privlači muhe i mrave.

Što je puno mrvica?

\section{Tanjur}

Stol

Most u gradu koji je pun vozila živcira sve sudionike u prometu.

Što je puno vozila?

Grad Most

Juha u zdjeli koja je prilično vruća treba se ohladiti vani na balkonu.

Što je prilično vruće?

Juha

Zdjela 


\section{2) Ispitivanja u stvarnom vremenu}

Prvi eksperiment u stvarnom vremenu (genitivne dopune i prijedložno-padežni izrazi)

Krov vrtića što je posve zapušten živcira baš sve tamošnje zaposlenike.

Ograda vrtića što je posve zapušten živcira baš sve tamošnje zaposlenike.

Krov zgrade što je posve zapušten živcira baš sve tamošnje zaposlenike.

Restoran hotela što je lijepo uređen svojim izgledom iznenađuje goste.

Dvorana hotela što je lijepo uređen svojim izgledom iznenađuje goste.

Restoran škole što je lijepo uređen svojim izgledom iznenađuje goste.

Naslov članka što je pun neistina postaje predmetom vrućih rasprava.

Verzija članka što je pun neistina postaje predmetom vrućih rasprava.

Naslov priče što je pun neistina postaje predmetom vrućih rasprava.

Dionica utrke što je jako naporna iscrpljuje sve sudionike natjecanja.

Start utrke što je jako naporna iscrpljuje sve sudionike natjecanja.

Dionica puta što je jako naporna iscrpljuje sve sudionike natjecanja.

Tvornica čokolade što je proslavila zemlju trenutno je na svim vijestima.

Festival čokolade što je proslavila zemlju trenutno je na svim vijestima.

Tvornica sira što je proslavila zemlju trenutno je na svim vijestima.

Naslovnica knjige što je jako zanimljiva privlači sve ljude u prostoriji.

Nastavak knjige što je jako zanimljiva privlači sve ljude u prostoriji.

Naslovnica albuma što je jako zanimljiva privlači sve ljude u prostoriji. 
Prozor na krovu što se počeo tresti važna je tema među stanarima.

Cijev na krovu što se počeo tresti važna je tema među stanarima.

Prozor na zgradi što se počeo tresti važna je tema među stanarima.

Hotel na trgu što je prepun stranaca postaje atrakcija širom Europe.

Crkva na trgu što je prepun stranaca postaje atrakcija širom Europe.

Hotel na obali što je prepun stranaca postaje atrakcija širom Europe.

Kuća na rijeci što je omeđena trnjem zastrašuje svu djecu u selu.

Most na rijeci što je omeđena trnjem zastrašuje svu djecu u selu.

Kuća na brdu što je omeđena trnjem zastrašuje svu djecu u selu.

Slika u sobi što je prepuna prašine danas se treba detaljno očistiti.

Krevet u sobi što je prepuna prašine danas se treba detaljno očistiti.

Slika u stanu što je prepuna prašine danas se treba detaljno očistiti.

Stazica u šumi što je prepuna stakla česta je tema među seljanima.

Parkić u šumi što je prepuna stakla česta je tema među seljanima.

Stazica u parku što je prepuna stakla česta je tema među seljanima.

Prizor u filmu što je prilično tužan oduševljava sve ljude u publici.

Scena u filmu što je prilično tužan oduševljava sve ljude u publici.

Prizor u operi što je prilično tužan oduševljava sve ljude u publici. 


\section{Umetnuti podražaji}

Ivana je pojela toliko kolača da sigurno neće moći večerati sendvič.

Mjesto iznad brda toliko mi je drago da vrlo često tamo navraćam.

Joško je tako zabrinut za Karla da ne spava i ne jede danima.

Vedran toliko trči za loptom da se ne može koncentrirati na posao.

Filip je kupio tako lošu kravatu da sam mu rekla da ju vrati u dućan.

Darko toliko voli slušati glazbu da je prestao gledati filmove u kinu.

Vijesti toliko zaglupljuju narod da od danas neću kupovati novine.

Lorena je pojela toliko pokvarenog sira da mora uzeti lijek.

Tinova majka toliko brine o njemu da mu stalno kuha i čisti stan.

Marta se jako zaljubila u Filipa pa se počne tresti čim on uđe u razred.

Majka i otac malene Ive stalno se svađaju pa uznemiravaju susjede.

Ljiljana jako voli umjetnost pa stalno odlazi u muzeje i kazališta.

Vlak je kasnio u polasku pa Zrinka neće na vrijeme stići na priredbu.

Livada iznad šume često zaraste pa ju netko redovito mora kositi.

Mirko jako voli svoj posao pa puno radi za sramotno nisku plaću.

Sanja ne razmišlja o svojim postupcima pa se već puno puta opekla.

Dražen je loše napisao test pa se boji da neće smjeti na koncert.

Klizanje je Jelenin najdraži sport pa svako jutro rano odlazi na klizalište.

Bojana je se ne može naviknuti na smog iako već dugo živi u gradu.

Klara gleda film o postanku svijeta iako je već pogledala predstavu.

Jana ima osjećaj da neće ništa stići iako je oduvijek vrlo organizirana.

Slavko opet piše pjesme o ratu iako to baš nitko ne želi čitati.

Ivanka nedjeljom pjeva u zboru makar joj se nekad strašno ne da.

Jakov mi je najljepše muško ime iako sina nisam tako nazvala.

Vanji sklad u obitelji vrijedi više od novca iako je nekima karijera važnija. 
Viktor jako voli brze automobile iako ne zna voziti niti bicikl.

Katarina još uživa u sportu iako odmalena svaki dan mora trenirati.

Maja se boji sama vraćati kući iako živi u lijepom i mirnom selu.

Lubenica je moje najdraže voće makar se samo ljeti mogu daviti u njoj.

Bitno mi je uza se imati dobre ljude makar sam dosta samostalan.

Silvija je jučer jako pokisnula iako su vijestima najavili sunce.

Tea može dragati guštere iako se jako boji drugih gmizavaca.

U šumi ponekad beremo tartufe makar moramo paziti da nas ne ulove.

Jakov trči maratone iako oduvijek ima problema s disanjem.

Profesorica je za sobom ostavila neizbrisiv trag iako je otišla u mirovinu.

Luka nikome ne duguje novac iako stalno zapada u nove dugove. 
Sin poznatog pjevača koji ima srčanu manu glavna je tema u dvorani.

Bend poznatog pjevača koji ima srčanu manu glavna je tema u dvorani.

Pjevač poznatog benda koji ima srčanu manu glavna je tema u dvorani.

Otac slavnog pisca koji je sinoć ubijen odavno je svima prirastao srcu.

Roman slavnog pisca koji je sinoć ubijen odavno je svima prirastao srcu.

Pisac slavnog romana koji je sinoć ubijen odavno je svima prirastao srcu.

Prijatelj našega šefa koji jako voli slavlja često uveseljava sve goste.

Zbor našega šefa koji jako voli slavlja često uveseljava sve goste.

Šef našega zbora koji jako voli slavlja često uveseljava sve goste.

Brat starog vlasnika koji pije puno vina danas se srušio i ozlijedio ljude.

Kafić starog vlasnika koji pije puno vina danas se srušio i ozlijedio ljude.

Vlasnik starog kafića koji pije puno vina danas se srušio i ozlijedio ljude.

Sin bogatog trenera koji ima tešku bolest glavna je tema svake kave.

Klub bogatog trenera koji ima tešku bolest glavna je tema svake kave.

Trener bogatog kluba koji ima tešku bolest glavna je tema svake kave.

Vozač našeg voditelja koji mrzi svoj posao opet je uzrokom brojnih svađa.

Ured našeg voditelja koji mrzi svoj posao opet je uzrokom brojnih svađa.

Voditelj našeg ureda koji mrzi svoj posao opet je uzrokom brojnih svađa. 
Pramac starog broda koji je sav zahrđao veoma je drag svim mještanima.

Kapetan starog broda koji je sav zahrđao veoma je drag svim mještanima.

Brod starog kapetana koji je sav zahrđao veoma je drag svim mještanima.

Motor starog auta koji je skroz trošan hitno bi trebao majstoru na pregled.

Vozač starog auta koji je skroz trošan hitno bi trebao majstoru na pregled.

Auto starog vozača koji je skroz trošan hitno bi trebao majstoru na pregled.

Podrum starog stana koji je prepun smeća živcira baš sve ljude u zgradi.

Vlasnik starog stana koji je prepun smeća živcira baš sve ljude u zgradi.

Stan starog vlasnika koji je prepun smeća živcira baš sve ljude u zgradi.

Naslov lošeg članka koji je prepun grešaka važna je tema među novinarima.

Autor lošeg članka koji je prepun grešaka važna je tema među novinarima.

Članak lošeg autora koji je prepun grešaka važna je tema među novinarima.

Nastavak dobrog filma koji ima sretan kraj svima je uljepšao ljetnu večer.

Redatelj dobrog filma koji ima sretan kraj svima je uljepšao ljetnu večer.

Film dobrog redatelja koji ima sretan kraj svima je uljepšao ljetnu večer.

Uvod važnog izvještaja koji je loše sročen u svima stvara veliku nervozu.

Autor važnog izvještaja koji je loše sročen u svima stvara veliku nervozu.

Izvještaj važnog autora koji je loše sročen u svima stvara veliku nervozu. 


\section{Umetnuti podražaji}

Gledalište ne prestaje pljeskati kad završi glumčev monolog.

Ana se rasplače svaki put kad na radiju zasvira pjesma njezinog oca.

Svećenik je izlazio iz samostana kad je nešto eksplodiralo u kuhinji.

Ivani je pozlilo dok je u punoj čekaonici čekala svoj red za pregled.

Marija uvijek ima izložbe kad vani pljušti kiša i sijevaju munje.

Janko je doživio malu nezgodu kad se penjao na drvenu pozornicu.

Lovci u šumi često počnu pucati kad u daljini čuju šuštanje lišća.

Hrvoju šefovi prijete otkad je najavio da će dati ostavku.

Luka piše najbolje pjesme kada doživi ljubavni brodolom.

Jelena se smrznula dok je popodne na cesti čekala Davora.

Cijeli autobus smrdi po siru kad se Martina vraća iz Francuske.

Žarko ne može gledati dnevnik kada prenose sjednice Sabora.

Ivan ne izlazi iz radionice otkako mu je žena umrla prošle godine.

Marija se uvijek razboli kada treba nastupati pred publikom.

Fran se strašno naljuti kad mu mama počne zapovijedati.

Lucija upoznaje cijelu Hrvatsku kada odlazi na školske izlete.

Miro putuje po Africi kada mu dosadi stresni europski život.

Majka pjevuši operne arije svaki put kad kuha nedjeljni ručak.

Tepih je silno prljav jer je Klaudija sinoć prolila alkoholno piće.

Josip mi je dao poklon jer sam mu pomogla s pronalaskom posla.

Nagrađeni glumac neće preuzeti nagradu jer je doživio nesreću.

Moj pas Floki je u kazni jer je jučer pojeo pečeno meso sa stola.

Baka već godinama ne odlazi na tržnicu jer sama uzgaja svoje povrće.

Goran noćima sanja kolače jer je već sedam dana na sportskoj dijeti.

Luka mora pogledati tu predstavu jer ju je Marko jako nahvalio. 
Mama se boji da će se krovište urušiti jer je kuća stvarno prastara.

Ana mora kupiti novi radio jer stari proizvodi čudne zvukove.

Cijeli hladnjak je ljepljiv jer je Lovro slučajno prolio sok.

Zvonku prijete deložacijom jer ne plaća kredit i nema papire.

Ne pratim politiku jer ne podnosim pokvarene i lažljive ljude.

Lovro je Mirjani kupio narukvicu jer su se jučer strašno posvađali.

Vesna ne može na posao jer ju opet muči teška migrena.

Djeca se manje igraju na igralištu jer svi imaju mobitele i tablete.

Jasna ne pozdravlja prijatelje jer joj je slava udarila u glavu.

Lucija više ne čita novine jer prenose samo loše vijesti.

Gordana je omiljena u svakome društvu jer uvijek zrači pozitivom. 


\subsection{Popis tablica i slika}

\section{1) Tablice}

Tablica 1. Pregled preferencija vezivanja u različitim jezicima.

Tablica 2. Primjer ispitnih podražaja iz istraživanja Gilboy i sur. (1995).

Tablica 3a. Raspon ukupnog $N$ grafema, $N$ riječi u rečenici te slovne duljine relevantnih regija (prvi eksperiment, oba uvjeta).

Tablica 3b. Raspon ukupnog $N$ grafema, $N$ riječi u rečenici te slovne duljine relevantnih regija (drugi eksperiment, oba uvjeta).

Tablica 4a. Srednje vrijednosti za $N$ grafema i riječi te $N$ slovnih mjesta u ključnim regijama interesa za oba uvjeta (prvi eksperiment).

Tablica 4b. Srednje vrijednosti za $N$ grafema i riječi te $N$ slovnih mjesta u ključnim regijama interesa za oba uvjeta (drugi eksperiment).

Tablica 5. Prosječne vrijednosti čestotnosti riječi u svim uvjetima i obama eksperimentima.

Tablica 6. Srednja vrijednost čestotnosti imenica unutar NP u različitim uvjetima i prikaz rezultata $t$-testa za testiranje razlika u čestotnosti (prvi eksperiment).

Tablica 7. Srednja vrijednost čestotnosti imenica unutar NP u različitim uvjetima i prikaz rezultata $t$-testa za testiranje razlika u čestotnosti (drugi eksperiment).

Tablica 8. Prosječne vrijednosti bodova na zadatku sročnosti po uvjetima i testiranje značajnosti razlika među uvjetima.

Tablica 9. Prosječne vrijednosti bodova na zadatku značenjske prihvatljivosti po uvjetima i testiranje značajnosti razlika među uvjetima.

Tablica 10. Obilježja (spol i dob) sudionika koji su sudjelovali u mjerenjima u odgođenom vremenu.

Tablica 11. Deskriptivna statistika za mjeru raspona radnoga pamćenja.

Tablica 12. Prikaz mjera pokreta oka (zavisnih varijabli) i njihova operacionalizacija.

Tablica 13. Primjeri ispitnih podražaja i njihova podjela s obzirom na vrstu NP i značenjske odnose imenica unutar NP koja prethodi odnosnoj zamjenici. 
Tablica 14. Prosječne vrijednosti svih analiziranih mjera u svim uvjetima (prvi eksperiment u stvarnom vremenu).

Tablica 15. Prikaz glavnih efekata na promatranim mjerama (zavisnim varijablama) za faktor imenska skupina; GD/PPI (prvi eksperiment u stvarnom vremenu).

Tablica 16. Prikaz glavnih efekata na promatranim mjerama (zavisnim varijablama) za faktor vrsta vezivanja; N1/N2 (prvi eksperiment u stvarnom vremenu).

Tablica 17. Interakcija između dvaju faktora (imenska skupina i vrsta vezivanja).

Tablica 18. Prosječne vrijednosti svih analiziranih mjera u svim uvjetima (drugi eksperiment u stvarnom vremenu).

Tablica 19. Prikaz glavnih efekata na promatranim mjerama (zavisnim varijablama) za faktor živost; živo/neživo (drugi eksperiment u stvarnom vremenu).

Tablica 20. Prikaz glavnih efekata na promatranim mjerama (zavisnim varijablama) za faktor vrsta vezivanja; N1/N2 (drugi eksperiment u stvarnom vremenu).

Tablica 21. Interakcija između dvaju faktora (živost i vrsta vezivanja).

Tablica 22. Iskazi nekih sudionika i čimbenici koji su utjecali na njihove preferencije prilikom ispunjavanja upitnika. 


\section{2) Slike}

Slika 1. Proces psiholingvističkog istraživanja, od problematike do krajnjega doprinosa.

Slika 2. Preferencije vezivanja s obzirom na različite odnose imenica u NP (a. i b.); preuzeto od Frazier i Clifton (1997: 281).

Slika 3. Sažeti prikaz strukture upitnika prosudbe (GD je genitivna dopuna; PPI je prijedložnopadežni izraz).

Slika 4. Prikaz strukture složenoga zadatka raspona radnoga pamćenja pri računanju.

Slika 5. Sažeti prikaz strukture eksperimenta u stvarnom vremenu.

Slika 6. Prikaz ispitivanja u stvarnom vremenu.

Slika 7. Prosječni postotci vezivanja na N1 u dvama uvjetima.

Slika 8. Postotak odabira N1 s obzirom na obilježje živosti antecedenata u genitivnoj dopuni.

Slika 9. Postotak odabira N1 s obzirom na obilježje referencijalnosti antecedenta u genitivnoj dopuni.

Slika 10. Grafički prikaz glavnih efekata na mjeri ukupno vrijeme čitanja (faktor vrsta vezivanja; N1/N2).

Slika 11. Grafički prikaz glavnih efekata na mjeri $N$ regresivnih pokreta oka u regiju NP (faktor imenska skupina; GD/PPI i vrsta vezivanja; N1/N2).

Slika 12. Grafički prikaz glavnih efekata na mjeri ukupno trajanje fiksacija u regiji Razrješenje dvosmislenosti (faktor vrsta vezivanja; N1/N2).

Slika 13. Grafički prikaz glavnih efekata na mjeri prvi prijelaz okom u regiji Razrješenje dvosmislenosti (faktor imenska skupina; GD/PPI).

Slika 14. Grafički prikaz glavnih efekata na mjeri $N$ fiksacija u regiji Razrješenje dvosmislenosti (faktor vrsta vezivanja; N1/N2).

Slika 15. Grafički prikaz glavnih efekata na mjeri $N$ regresivnih pokreta oka u regiju Razrješenje dvosmislenosti (faktor vrsta vezivanja; N1/N2).

Slika 16. Grafički prikaz glavnih efekata na mjeri ukupno vrijeme čitanja (faktor živost; živo/neživo i vrsta vezivanja; N1/N2).

Slika 17. Grafički prikaz glavnih efekata na mjeri ukupno trajanje fiksacija u regiji NP (faktor živost; živo/neživo). 
Slika 18. Grafički prikaz glavnih efekata na mjeri $N$ fiksacija u regiji NP (faktor živost; živo/neživo i vrsta vezivanja; N1/N2).

Slika 19. Grafički prikaz glavnih efekata na mjeri $N$ regresivnih pokreta oka u regiju NP (faktor vrsta vezivanja; N1/N2).

Slika 20. Grafički prikaz glavnih efekata na mjeri prvi prijelaz okom u regiji Razrješenje dvosmislenosti (faktor živost; živo/neživo).

Slika 21. Grafički prikaz glavnih efekata na mjeri $N$ regresivnih pokreta oka u regiju Razrješenje dvosmislenosti (faktor vrsta vezivanja; N1/N2).

Slika 22. Prikaz pokreta oka (fiksacije, sakade i regresije) u uvjetima vezivanja na N1 i N2 (prvi eksperiment).

Slika 23. Prikaz pokreta oka (fiksacije, sakade i regresije) u uvjetima vezivanja na N1 i N2 (drugi eksperiment).

Slika 24. Prikaz ukupnih vremena čitanja (ms) za obje vrste odnosnih rečenica (različita vrsta NP; GD i PPI) u trima uvjetima vezivanja.

Slika 25. Prikaz ukupnih vremena čitanja (ms) za obje vrste odnosnih rečenica (različita obilježja živosti; živo i neživo) u trima uvjetima vezivanja. 


\section{ŽIVOTOPIS AUTORICE}

Ana Matić rođena je 27. siječnja 1991. u Zagrebu. Nakon završene II. Opće gimnazije upisuje studij Logopedije na Edukacijsko-rehabilitacijskom fakultetu Sveučilišta u Zagrebu. U rujnu 2014. brani diplomski rad i stječe titulu mag. logoped. Dobitnica je Dekanove nagradu za najviši prosjek ocjena tijekom prve godine studija na diplomskome studijskom programu Logopedija (2014.), Dekanove nagrade za postignute izvrsne rezultate i cjelokupan uspjeh tijekom studija (2015.) te Posebnoga priznanja za promidžbu kvalitetnog rada i aktivnosti studenata. Po završetku studija postaje suradnicom Laboratorija za psiholingvistička istraživanja Odsjeka za logopediju, a 2016. i asistenticom na istome Odsjeku. Iste godine upisuje Poslijediplomski doktorski studij lingvistike na Filozofskome fakultetu Sveučilišta u Zagrebu.

Glavna su joj područja znanstvenog interesa jezični razvoj i jezična obrada uredne, kao i populacije s razvojnim i stečenim jezičnim poremećajima. Dosad se usavršavala na nekoliko kratkotrajnih studijskih razmjena, preko 15 radionica, edukacija i ljetnih škola te je aktivno izlagala na preko 20 konferencija i znanstvenih skupova. Sudjelovala je i/ili trenutno sudjeluje na jednom stručnom IPA projektu, jednom znanstvenom HRZZ projektu, dvama COST projektima i jednom bilateralnom međunarodnom projektu (suradnja sa Sveučilištem u Beču). Dobitnica je kratkotrajne istraživačke stipendije DAAD za posjet Sveučilištu u Konstanzu (2019./2020.). Članica je Hrvatskog logopedskog društva, Hrvatskog fillološkog društva te Hrvatskog društva za primijenjenu lingvistiku, a u razdoblju od 2019. do 2020. obnaša funkciju voditeljice Zagrebačkoga lingvističkog kruga. (Su)autorica je oko 15 znanstvenih radova (članaka i poglavlja u knjigama), probirnoga testa za procjenu jezičnih sposobnosti djece predškolske dobi te kliničkoga testa za procjenu afazije. 